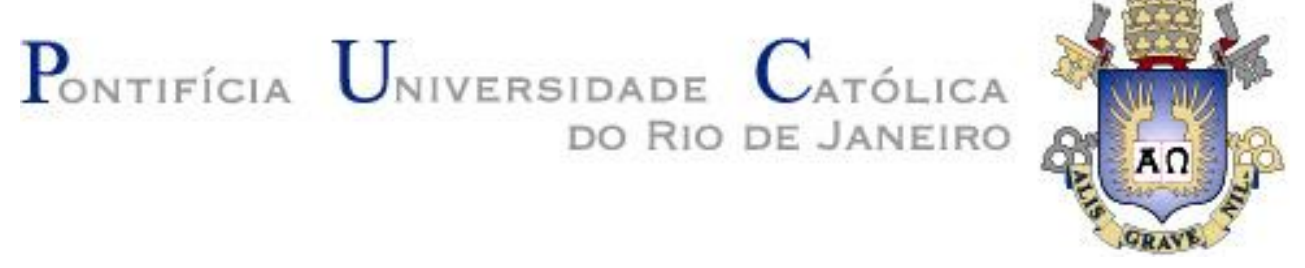

Cícero Manoel Bezerra

Poder-Serviço no Ministério Cristão Midiático: Análise Contextual e Teológica

Tese apresentada ao Programa de Pós-graduação em Teologia da PUC-Rio, como requisito parcial para obtenção do grau de Doutor em Teologia.

Orientador: Prof. Abimar Oliveira de Moraes 
Cícero Manoel Bezerra

\title{
Poder-Serviço no Ministério Cristão Midiático: Análise Contextual e Teológica
}

Tese apresentada como requisito parcial para obtenção do grau de Doutor pelo Programa de Pósgraduação em Teologia do Departamento de Teologia do Centro de Teologia e Ciências Humanas da PUC-Rio. Aprovada pela Comissão Examinadora abaixo assinada.

\author{
Prof. Abimar Oliveira de Moraes \\ Orientador \\ Departamento de Teologia - PUC-Rio \\ Prof. Luis Corrêa Lima \\ Departamento de Teologia - PUC-Rio \\ Prof $^{\mathrm{a}}$. Maria Teresa de Freitas Cardoso \\ Departamento de Teologia - PUC-Rio \\ Prof. Dinamara Pereira Machado \\ Centro Universitário Internacioal \\ Prof. Jaziel Guerreiro Martins \\ Faculdade Batista do Paraná \\ Prof $^{\mathrm{a}}$. Monah Winograd \\ de Teologia e Ciências Humanas - PUC-Rio
}

Coordenadora Setorial de Pós-Graduação e Pesquisa do Centro

Rio de Janeiro, 17 de fevereiro de 2017. 
Todos os direitos reservados. É proibida a reprodução total ou parcial do trabalho sem autorização da universidade, da autor e do orientador.

\section{Cícero Manoel Bezerra}

Graduou-se em Teologia pela Faculdade de Teologia Avançada - São Paulo, cursou Teologia com ênfase em Missões - Seminário Teológico Betânia de Belo Horizonte, Pós-graduação em Teologia Pastoral pela Faculdade Sul Americana - Londrina, PR, Mestre em Teologia pela PUC-PR. Tem experiência como professor há 30 anos, trabalha com treinamento de líderes e mobilização de lideranças estratégicas, autor de 16 livros. Entre eles se destacam Lideranças Emergentes no Contexto Latino Americano e Liderança Exemplar. São ainda títulos de sua autoria: Os Dez Mandamentos do Professor; Missão Integral da Igreja (Série - Vida Excelente); Seguindo o Modelo do Mestre (Série - Vida Excelente); Como Viver uma Vida Simples; Igreja nas Casas; Os Dez mandamentos do Líder de Grupos Caseiros; Segredos da Evangelização: Tarefa de Muitos realizada por Poucos; Influenciando Gerações; Conversas Sobre Jesus: Série Conversas Sobre o Poder; Os Desafios da Igreja Na Cidade e Conversas sobre Espiritualidade. Participação em atividades comunitárias na cidade de Curitiba através da mobilização de líderes cristãos. Participa da organização do movimento "Marcha para Jesus" na cidade de Curitiba, que conta com a participação de aproximadamente 300 mil pessoas. Experiência internacional, viajou para mais de 40 países para apresentação de palestras e ações estratégicas. Professor na Faculdade de Teologia Betânia na cidade de Curitiba, Paraná. Professor no curso de Pós-Graduação, IBPEX, Produção de material didático. Faz parte da Confederação Brasileira de Pastores e da Aliança Cristã Evangélica Brasileira. Coordenador curso de pós-graduação da Faculdade Teológica Betânia, Coordenador do Curso de Bacharel em Teologia, EAD no grupo UNINTER. Experiência na área editorial e em produção de livros.

Ficha Catalográfica

\section{Bezerra, Cícero Manoel}

Poder-serviço no Ministério Cristão Midiático : análise contextual e teológica / Cícero Manoel Bezerra ; orientador: Abimar Oliveira de Moraes. - 2017. $233 \mathrm{f}$; ; $30 \mathrm{~cm}$

Tese (doutorado)-Pontifícia Universidade Católica do Rio de Janeiro, Departamento de Teologia, 2017.

Inclui bibliografia

1. Teologia - Teses. 2. Poder. 3. Mídia. 4. Religião. I. Moraes, Abimar Oliveira de. II. Pontifícia Universidade Católica do Rio de Janeiro. Departamento de Teologia. III. Título. 


\section{Agradecimentos}

Agradeço a minha esposa Conceição Bezerra ela teve uma contribuição significativa para que eu pudesse gastar tempo com esse projeto.

Agradeço aos filhos nora, genro e netos por acreditarem nesse projeto.

Agradeço sinceramente ao professor Dr. Abimar Oliveira de Moraes, além de ser um orientador tem sido um companheiro.

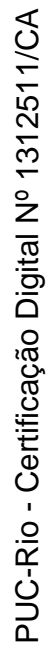

Agradeço a Missão Evangélica Betânia e ao Centro Universitário Uninter pelo Apoio. 


\section{Resumo}

Bezerra, Cícero Manoel; Moraes, Abimar Oliveira de. Poder-Serviço no Ministério Cristão Midiático: Análise Contextual e Teológica. Rio de Janeiro, 2017, 233p. Tese de Doutorado - Departamento de Teologia, Pontifícia Universidade Católica do Rio de Janeiro.

Esta tese foi desenvolvida para abordar questões relacionadas com o poder eclesial e as ações midiáticas, pois têm surgido questões sobre como o avanço no campo das comunicações e a tecnologia contemporânea podem servir de ferramenta para o anúncio do evangelho. A questão do poder eclesial também foi levada em conta e, por sua vez, foi desenvolvida uma análise do assunto poder de forma neutra, tentando reconhecer a influência da religião na sociedade e de que forma essa ação gera alternativas de poder. Chegou-se à conclusão de que o poder pode ser exercido de forma legítima quando se transforma em serviço. Os passos desenvolvidos nesta tese foram pautados da seguinte forma: Uma análise conceitual a respeito do poder eclesial e suas abrangências, cujo estudo foi feito de maneira bibliográfica, por meio de pesquisa sobre vários livros e vários teóricos que já escreveram e pesquisaram sobre o assunto. Também foram abordados os aspectos teológicos do poder e da comunicação midiática, e de que forma a teologia pode servir de referência para pautar os temas. Sendo uma investigação teológica, o ministério de Jesus foi analisado como base, servindo de referência para aqueles que exercem o ministério pastoral midiático e também para aqueles que postulam esse serviço. No decorrer do trabalho foi desenvolvida uma pesquisa de campo com quatro líderes religiosos que exercem o ministério midiático de grande alcance. É de valia esclarecer que, no decorrer desta análise, identificou-se que há falta de material teórico para pautar aqueles que exercem o ministério midiático. A conclusão da tese, a partir da análise dos resultados aponta para certa neutralidade do poder eclesial, que tanto pode ser usado de forma negativa quanto positiva, dependendo do caráter daquele que o exerce. Outro ponto a ser destacado refere-se ao uso da mídia e da tecnologia que tendem a contribuir de forma legítima e eficaz para ajudar as pessoas.

\section{Palavras-chave}

Poder; Mídia; Religião. 


\section{Abstract}

Bezerra, Cícero Manoel; Moraes, Abimar Oliveira de. Power-service in the Media Christian Ministry. Contextual and Theological Analysis. Rio de Janeiro, 2016, 233p. Tese de Doutorado- Departamento de Teologia, Pontifícia Universidade Católica do Rio de Janeiro.

This Thesis was developed to approach issues related to the ecclesial power and the media actions. Taking into account the advance in the area of communications and the contemporaneous technology, questions arise concerning how these choices may act as tools for the announce of the Gospel. The question of the ecclesial power was also considered and an analysis of power was developed, in a neutral way, trying to answer questions on the influence of religion in society as well as the manner this action generates alternatives of power. The conclusion is that power may be exercised in a legitimate way, when it transforms itself in service. The steps developed in the dissertation were taken the following way: a conceptual analysis about the ecclesial power and its scope, whose study was done in a bibliographic way, by means of research on several books and on the findings of several theoretical writers. In addition, the theological aspects of power and of media communication were approached, as well as the way theology may act as reference to draw the themes on. Being a theological investigation, the approaches were based on the principles of theology, the ministry of Jesus was analyzed as a base, acting as reference to those who perform the pastoral media ministry and to those who postulate this service. As the research was being developed, a field research with four religious leaders who exercise the far-reaching media ministry took place. It is worth explaining that, in the course of this investigation, the lack of theoretical material to support those who exercise the media ministry was perceived. The conclusion of the dissertation, drawn on the analyses of the findings, points to certain neutrality of the ecclesial power, which may be used in a negative way as well as in positive one, depending on the character of the one who exercise it. Another point to be emphasized refers to the use of the media and the technology, as they tend to contribute legitimately and effectively in order help people. 


\section{Keywords}

Power; Media; Religion

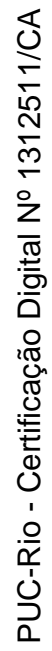




\section{Sumário}

1. Introdução

2. O Poder: fenômeno humano, midiático e religioso

2.1. O Poder como fator intrínseco ao humano

2.1.1. A Gênesis do Poder

2.1.2. O Exercício do Poder

2.2. O Poder em perspectivas midiáticas

2.2.1. A sedução do poder midiático

2.2.2. A mídia como "quarto poder" 36

2.2.3. O poder das instituições midiáticas 39

2.2.4. O poder da mídia numa sociedade de consumo 43

2.2.5. A desregulamentação midiática $\quad 48$

2.2.6. A degradação do poder $\quad 54$

2.3. O sujeito midiático: uma nova imagem do humano 57

2.3.1. Alguns desafios para o sujeito midiático pós-moderno $\quad 59$

2.4. O poder religioso e sua relação com o sujeito midiático 63

2.4.1 Da valorização do carisma pessoal ao culto à pessoa $\quad 70$

2.5 Conclusão $\quad 77$

3. O Poder-serviço: uma leitura bíblico-teológica 78

3.1. Alguns conceitos bíblicos sobre o poder 80

3.2. O ministério de Jesus como exercício de poder 82

3.3. Jesus é o modelo para o ministério cristão 90

3.4. O modelo de poder-serviço proposto pelo Apóstolo Paulo (Atos 20, 17-38)

3.4.1. Paulo e seu exemplo no serviço 107

3.4.2. Paulo e o oficio dos prepostos 112

3.4.3. O poder requer compromisso com a vocação 114

3.4.4. No serviço há o desgaste emocional 119

3.5. A relação entre a teologia e o poder 125

3.5.1. O poder- serviço na prática 132

3.6. Conclusão e considerações finais 135

4. Ministério midiático na perspectiva do Poder-Serviço 137

4.1. A figura do pastor no ministério cristão midiático 143 
4.2. O ministério midiático tem sido desenvolvido num ambiente pós-moderno

4.3. O ministério midiático frente a teoria da ação comunicativa de Habermas

4.4. Desafios para o ministério cristão midiático

4.5. Repensando o ministério midiático cristão

5. Conclusão

6. Referências bibliográficas

Apêndice A - Transcrição das Entrevistas

Apêndice B - Respostas dos Pesquisados 


\section{Introdução}

Os estudos desenvolvidos nesta tese têm como objetivo responder às perguntas decorrentes da relação entre o poder eclesial a mídia e o ministério cristão. É certo que as perguntas são muitas e não será esgotado o assunto a partir desses estudos, por isso pretende-se apresentar algumas pautas a respeito do tema, com o desejo que possa ser útil para aqueles que já desenvolvem o ministério midiático e para aqueles que postulam tal função.

A sociedade contemporânea vive em uma época e realidade que disponibiliza a maior quantidade de recursos tecnológicos que uma geração já experimentou; o avanço da tecnologia é notório em todas as áreas, entre elas a comunicação. Os recursos são diversos e as oportunidades são muitas, portanto é necessário fazer uma boa fundamentação teológica a respeito do assunto, principalmente quando se trata de um diálogo entre o poder eclesial e as grandes mídias.

Outro passo utilizado para o aperfeiçoamento dos assuntos e aspectos para chegarmos a apontamentos práticos foi o uso da pesquisa de campo. Foram consultados quatro líderes de influência midiática no Brasil. Entre os católicos, a entrevista aconteceu com um jovem padre que exerce o ministério em uma paróquia na zona norte na cidade de São Paulo. Também cabe destacar a excelente participação de um conhecido padre da mídia nacional. Aliás, sua contribuição pode ser destacada como o ponto alto da tese.

Por sua vez tivemos, também, a participação dos protestantes. O primeiro foi um pastor batista com muito transito no ambiente virtual e com prática sobre o assunto. Sua contribuição se deu por meio da organização e de pautas objetivas a respeito desse ministério. Por fim ocorreu o contato com um pastor luterano, muito experiente e conhecido no Brasil e vários países do mundo, que possui larga experiência no ambiente virtual e é autor de vários livros de teologia e missão.

Esses líderes foram identificados e escolhidos por seu impacto midiático e por sua contribuição especifica para o ministério cristão midiático.

A partir da pesquisa e conversa com os lideres cristãos foi desenvolvida 
uma tabulação, construindo, assim, um texto interativo onde as falas e apontamentos dos lideres serviram com apoio e reflexão para os apontamentos.

Quais são os eixos a serem analisados a partir do novo modelo que se apresenta na comunicação do evangelho de Jesus Cristo e como fazer uso das modernas tecnologias sem perder a essência da mensagem cristã são algumas questões abordadas nessa tese. Vários teóricos foram estudados, várias pesquisas foram analisadas e todo o trabalho foi desenvolvido com a pretensão de apresentar conceitos que possam ser usados por aqueles que estão atuando nesse ambiente da comunicação religiosa.

No primeiro capítulo será desenvolvida uma análise do conceito de poder; por meio de uma pesquisa conceitual fundamentada em escritores teóricos e especialistas nesse assunto. O tema será tratado de tal forma que se possa reconhecer alguns caminhos propostos a respeito das origens do conceito de poder, também será uma realizada uma fundamentação a respeito do poder religioso com suas implicações e abrangências, pois esse tipo de poder tem sido analisado por muitas pesquisas. A religião e o poder andam juntos numa estrada muito estreita e é preciso descobrir pontos de equilíbrio, pois tanto o poder religioso como o poder como sistema medem forças para exercer influência sobre a sociedade.

Será usado como base de pensamento para a pesquisa e argumentação o fato de o "poder" ser conceituado a partir de sua força de influência. O poder em si é neutro, acontece a partir das decisões das pessoas, mas pode assumir caráter de moralidade, dependo das ações do sujeito, tanto para o bem quanto para o mal.

Ainda nesse capítulo será abordada a influência da mídia na sociedade. Por meio de uma fundamentação histórica e teórica, identificou-se a teoria do agendamento, um conceito que estuda quem monta as pautas midiáticas e quais são os interesses por de trás dos assuntos que são discutidos no dia a dia da sociedade. A força da mídia e dos instrumentos de comunicação pode ser descrita como um amplo sistema, como um polvo com vários braços que se infiltra em vários setores da sociedade. $\mathrm{O}$ impacto que se percebe da mídia nas questões governamentais, religiosas e sociais de forma geral é abrangente e pode-se dizer incalculável.

Como consequência do poder e da força da mídia na sociedade 
contemporânea, surge um sujeito midiático, travestido de inteligência, com alto poder de consumo e com força suficiente para exercer poder através de todo o sistema tecnológico e midiático que prevalece no ambiente social atual.

Assim, pensando no poder como influência, no poder religioso e no sistema midiático e nas diversas correntes ideológicas que se apresentam para o cidadão moderno, deve-se buscar um caminho de equilíbrio e fundamentação teórica nas Escrituras Sagradas que apresentam um estilo de vida equilibrado para o cidadão.

No segundo capítulo serão exploradas as fundamentações conceituais a respeito do poder, começando com as terminologias bíblicas adequadas para melhor entendimento a respeito do assunto.

Após a conceituação técnica, serão analisados os aspectos teológicos a respeito do poder, abordando tanto os eixos da teologia quanto das ideologias, tendo em vista o ambiente da religião e seu diálogo como a teologia, considerando o contexto latino-americano, onde será fundamentada a plataforma de análise. Afinal teologia se faz a partir do contexto em que o teólogo está inserido.

Outra análise será feita a respeito da teologia do poder ou o poder e a teologia. Também será abordada a questão sobre os perigos a respeito do poder, o conceito do domínio será estudado, a exploração sobre os mais fracos. A questão ética é fundamental para que o exercício do poder aconteça de acordo com os princípios ensinados por Deus, e será apresentado um estudo a esse respeito.

Surge então a análise do poder como serviço, na verdade pode-se se dizer que a consolidação genuína do poder acontece quando o serviço se torna evidente. Tomando como base o exemplo de Jesus, que no seu ministério deixou exemplos a serem seguidos, em especial quando assume a posição de servo, o Mestre demonstra seu interesse de ajudar e servir ao próximo, dando um exemplo que ultrapassa os limites da história.

Será explorado como Jesus se relacionou com o poder, os enfrentamentos realizados contra as estruturas institucionais de poder da época, tanto do poder militar de Roma quanto do poder religioso dos judeus. O ministério de Jesus se consolida a partir de seus enfrentamentos, do confronto com as autoridades religiosas. Por sua indignação e pelo senso absoluto de cumprir com a vontade 
de Deus, ele se levanta e profetiza contra os dominadores, seus atos demonstram justiça e age contra a exploração do pobre, do órfão, da viúva e do estrangeiro. Fazendo uma análise sobre as origens de Jesus e seu envolvimento com o povo pode-se pressupor que suas ações devem ser reproduzidas.

O propósito principal de Jesus é conectar todas as pessoas em torno do reino de Deus, e dessa forma Ele apresentar a salvação e perdão dos pecados, é assim que acontece a unidade do povo de Deus em torno de tudo aquilo que Jesus representa.

Para uma melhor compreensão, serão estudadas as instâncias de poder na época de Jesus, levando em conta principalmente o poder religioso. A partir dessa compreensão começa-se a identificar os fundamentos para o ministério cristão, Jesus apresenta caminhos e princípios que devem ser seguidos por aqueles que são vocacionados ou por outros que têm aspirações para tal.

A figura principal no ministério cristão (na tradição protestante) é o pastor, aquele que tem a tarefa de cuidar e de certa forma reproduzir os ensinamentos de Jesus. Após estudos percebeu-se como o ministério pastoral tem sido poluído por diferentes formas de ação correndo o risco de ser descaracterizado dos ensinos bíblicos.

Outro referencial bíblico estudado é o ministério do Apóstolo Paulo, a abrangência do seu ministério, sua forma de exercer o poder, a mobilização de líderes para que o trabalho dele pudesse ser desenvolvido com eficácia e os exemplos que ele deixou através de seu discurso para os presbíteros da igreja de Éfeso. Na sua essência, o Apóstolo coloca em prática os ensinamentos de Jesus, com seu trabalho árduo e dedicado, ele demonstra que o poder se consolida como serviço.

Após diálogos e análises, chega-se às perspectivas pastorais, como ser pastor nesse ambiente, como seguir o exemplo de Jesus num contexto diferente e com necessidades iguais, como comunicar a mensagem da salvação para uma sociedade pós-moderna que não se dá conta de suas necessidades. Analisando o poder pastoral como referência para o bem da sociedade, busca-se apontar caminhos para os pastores exercerem seu ministério de acordo com os embasamentos bíblicos e teológicos a respeito do assunto.

No entanto, os perigos do poder pastoral devem ser evitados, tendo em conta os ensinamentos do Mestre não se deve deixar levar pelas estruturas de 
poder que influenciam a sociedade contemporânea. Tendo em conta a abrangência dessa análise, esse capítulo tem por objetivo analisar conceitos teológicos a respeito do ministério cristão e apontar caminhos preventivos e adequados para comunicar as palavras de salvação e justiça para uma sociedade que sofre e precisa ser salva.

No terceiro capítulo estudou-se a respeito do ministério midiático e suas implicações, e a abordagem passa a ser mais prática do que conceitual. Foi desenvolvida uma pesquisa a partir de quatro entrevistas com experientes líderes cristãos midiáticos com alcance para milhares de pessoas e, a partir dessas conversas, foi constatado a falta de material teórico para aqueles que exercem o ministério midiático quanto para aqueles que pretendem exercer essa função.

O ministério cristão foi conceituado a partir de fundamentos bíblicos e corre-se o risco, nesta sociedade pautada por inovação, de esquecer os princípios bíblicos sobre como deve ser exercido o ministério. Os novos formatos de serviço, entre eles o ministério midiático, têm sua importância, mas não se pode alterar a essência.

A maneira como Jesus ensinou sobre e como deve ser exercido o ministério mais uma vez será levada em conta. A pessoa do Mestre, com Seu caráter integro, Sua personalidade equilibrada e bom senso, Sua missão bem definida para obedecer a vontade do Pai acima de todas as coisas, como também a Sua atitude, pois Ele sendo Deus assumiu a forma de servo para que pudesse se identificar com aqueles que creem.

Ainda nesse capítulo será realizada uma análise da pastoral numa perspectiva pós-moderna, como agir em meio a uma sociedade nova, com um alto grau de relativismo. A teoria da ação comunicativa de Habermas é estudada e levada em conta num prisma pastoral.

Por fim, no quarto capítulo chega-se aos estudos relacionados com fato de que é preciso repensar o ministério pastoral. Através de uma inteiração prática com os líderes cristãos entrevistados, apontam-se alguns caminhos, uma série de procedimentos e considerações que visam ajudar aqueles que exercem o ministério cristão midiático e para aqueles que pretendem iniciar-se nessa tarefa.

Ao analisar os textos e desenvolver a pesquisa sobre o poder-serviço no 
ministério cristão midiático foram desenvolvidas alternativas que poderão orientar aos lideres cristãos e apontar caminhos para nortear seus procedimentos perante as suas comunidades e, também, nas práticas cristãs perante a sociedade.

Quando os líderes cristãos atuais praticarem os princípios relacionados ao poder-serviço ensinado por Jesus estarão habilitados para ajudar aos pobres e oprimidos da sociedade. 


\section{O poder: fenômeno humano, midiático e religioso}

Neste capítulo será desenvolvido o conceito do poder, por meio de uma pesquisa conceitual e fundamentada a partir de escritores teóricos e especialistas desse assunto. Será desenvolvida uma base para a estrutura conceitual de fundamentação da tese defendida, visando traçar alguns caminhos propostos a partir das origens sobre o conceito do poder, também fazendo uma fundamentação a respeito do poder religioso com todas suas implicações e abrangências, pois esse tipo de poder tem sido fator para muitas pesquisas. A religião e o poder andam juntos numa estrada muito estreita e que aponta para a sociedade numa troca de influencias. No entanto, tanto o poder religioso como o poder como sistema medem forças para exercer influência sobre a sociedade.

Será usado como base de pensamento para a pesquisa e argumentação o fato de o "poder" ser analisado a partir de sua ação de influência.

Ainda será desenvolvida uma pesquisa sobre a influência da mídia na sociedade, por meio de análise histórica e teórica, que aponta para a teoria do agendamento, um conceito que estuda sobre quem monta as pautas e quais são os interesses por trás dos assuntos discutidos no dia a dia da sociedade.

A força da mídia e dos instrumentos de comunicação e o impacto que se percebe da mídia nas questões governamentais, religiosas, sociais de forma geral é abrangente e pode-se dizer incalculável.

Analisando o poder como influência, o poder religioso e o sistema midiático e as diversas correntes ideológicas que se apresentam para o cidadão moderno, deve-se buscar um caminho de equilíbrio e baseado nas Escrituras Sagradas que apresentam um melhor estilo de vida para o cidadão.

\subsection{O poder como fator intrínseco ao humano}

Várias definições podem ser comparadas para se analisar o poder, sem pretensões de enquadrar o assunto numa só perspectiva. Assim, é importante considerar diversos aspectos apresentados por diferentes pontos de vista ou até 
mesmo de vários teóricos que abordam a questão.

O poder é aqui definido relativamente não como uma simples propriedade. Bertrand Russell concisamente define o poder como "a produção de efeitos pretendidos", fazendo dele, assim, uma propriedade que pode permanecer a uma pessoa ou a um grupo em si. ${ }^{1}$

Pensar no poder como "a produção de efeitos pretendidos", torna-se interessante devido ao fato de constatar-se que ninguém exerce o poder sem pretensões finais. Assim, o indivíduo de boa índole ao exercer poder geralmente estará pensando no seu próximo ou no bem comum da humanidade; outro indivíduo com traços distorcidos de caráter, num primeiro momento estará pensando em si mesmo, ou se fizer o bem, segundo a "síndrome de Robin Hood", estará usando o povo ou o grupo e a quem se interessar para tirar algum tipo de vantagem no final.

De acordo com Thompson, poder "em um sentido mais amplo, é a capacidade de agir na busca de seus próprios interesses e objetivos" [...]e, se analisado a partir de um campo ou instituição, "é a capacidade que possibilita ou capacita alguns indivíduos a tomarem decisões, perseguirem certos fins ou alcançarem determinados interesses."2. Produzir ações é poder, almejar participação ou até mesmo impor decisões da parte de outros, tanto para o bem como para o mal.

Evidentemente a essência do poder é o controle sobre o espírito humano. A fase imediata de poder é espiritual, quando uma mente exerce sobre outra certa influência, ou se impõem, por si mesma, sem outros meios de comunicação. Isto é, ter poder e todos os que o possuem em alto grau são os animadores da sociedade, como, por exemplo, poetas, profetas, filósofos, inventores e estudiosos e cientistas de todos os tempos. Os grandes políticos, militares e organizadores religiosos, assim como os capitães das indústrias e de comércio também exercem esse papel. ${ }^{3}$.

Como não poderia haver relações de poder sem pontos de insubmissão que, por definição, lhe escapam; toda intensificação e toda extensão das relações de poder para submetê-los conduzem apenas aos limites do exercício do poder. Este

\footnotetext{
${ }^{1}$ LASSWELl, A.; KAPLAN, H. D. Poder e Sociedade. Brasília: Univers, 1999. p. 26.

${ }^{2}$ THOMPSON, J. B. Ideologia e Cultura Moderna. Teoria Social Crítica na era dos meios de comunicação de massa. Petrópolis R.J: Vozes, 1995. p. 36.

${ }^{3}$ MENDIETA, L. N. Sociologia de Poder. México: Universitária, 1976. p. 10.
} 
encontra então sua finalidade, seja um tipo de ação que reduz o outro a impotência total (uma vitória sobre o adversário substitui o exercício do poder), seja uma transformação daqueles que são governados em adversários. Em suma, toda estratégia de confronto sonha em tornar-se uma relação de poder; e toda relação de poder inclina-se, tanto ao seguir sua própria linha de desenvolvimento quanto ao se deparar com resistências frontais, a tornar-se estratégia vencedora. ${ }^{4}$

Weber" assim conceitua: "o poder significa a possibilidade de fazer triunfar no seio de uma relação social a sua própria vontade mesmo contra resistências, qualquer que seja a base em que se baseia tal possibilidade". O exercício da vontade vitoriosa, tanto para o bem quanto para o mal, caracteriza o uso do poder. Em circunstâncias diferentes, a sociedade, para funcionar ou existir, precisa que ações poderosas sejam exercidas, ou seja, alguém precisa conduzir as normas ou estabelecer filosofias e coordenar ações. Aqueles que seguem estão exercendo o poder de seguir, os que dirigem estão exercendo o poder de guiar a maioria para determinada direção.

No exercício de poder surgirão estratégias micro e macro. O império romano, por exemplo, desenvolveu, através de seus imperadores, uma estratégia de ser poderoso e governar com poder, e aqueles que não se enquadrassem estrategicamente seriam anulados. O poder, exercido através da força bruta, foi admirado por todos que faziam parte do seu "modus operandi": os súditos adoravam o imperador, ao ponto de darem sua própria vida em prol de seus ideais. Max Weber disse: "Por poder entendemos aqui, de um modo geral, a probabilidade que tem um homem, ou um grupo de homens, de impor sua própria

\footnotetext{
${ }^{4}$ M. FOCAULT apud RABINOW. P. e DREYUS. H. Uma Trajetória Filosófica. Para Além do Estruturalismo e da Hermenêutica. O Sujeito e o Poder. Rio de Janeiro: Florense Universitária, 1995. p. 39.

${ }^{5}$ Max Weber viveu no período em que as primeiras disputas sobre a metodologia das ciências sociais começavam a surgir na Europa, sobretudo em seu país, a Alemanha. Filho de uma família de classe média alta, com o pai advogado, Weber encontrou em sua casa uma atmosfera intelectualmente estimulante. Ainda era criança quando se mudaram para Berlim. Em 1882 foi para a Faculdade de Direito de Heidelberg. Um ano depois se transferiu para Estrasburgo, onde prestou o serviço militar. Em 1884 reiniciou os estudos universitários, em Göttingen e Berlim, dedicando-se as áreas de economia, história, filosofia e direito. Trabalhou na Universidade de Berlim como livre-docente, ao mesmo tempo em que era assessor do governo. Cinco anos depois, escreveu sua tese de doutoramento sobre a história das companhias de comércio durante a Idade Média. Publicou ensaios sobre a objetividade nas ciências sociais e a primeira parte de "A Ética Protestante e o Espírito do Capitalismo", que se tornaria sua obra mais conhecida e é de fato fundamental para a reflexão sociológica. 1864-1920) nasceu em Erfurt, Turíngia, Alemanha, no dia 21 de abril de 1864. Formou-se em Direito e doutorou-se em Economia. faleceu em consequência de uma pneumonia aguda. WEBER, M. Ciência e Política, Duas Vocações. São Paulo: Pensamento Cultrix Ltda, 2005, p. 12-25.
} 
vontade em uma ação comunitária inclusive contra a oposição dos demais membros" ${ }^{6}$. Para esse autor, a dominação é um caso especial de poder.

Quando as relações de poder estabelecidas são sistematicamente impostas, então a situação pode ser descrita como dominação. Relações de poder são sistematicamente assimétricas quando indivíduos ou grupos de indivíduos particulares possuem um poder de maneira estável, de tal modo que exclua ou se torne inacessível, em grau significativo a outros indivíduos ou grupos de indivíduos, não importando a base sobre a qual essa exclusão é levada a efeito. Nesses casos pode-se falar de indivíduos ou grupos "dominantes" e "subordinados", assim como daqueles indivíduos ou grupos que, em virtude de seu acesso parcial a recursos, ocupam uma posição intermediária. ${ }^{7}$

\subsubsection{A Gênesis do Poder}

Desde o início, o poder e sua influência estabeleceram-se como alicerces da civilização. Foi a partir do desejo de dominar e na luta pela posse que o ser humano começou a se organizar e a conviver socialmente. "Na luta pela sobrevivência as estruturas de poder foram se consolidando". Até onde se sabe, o ser humano é o único ser em todo universo que se conscientizou da significação ${ }^{8}$ do poder e percebeu desde os primórdios de sua história que somente ele conseguia usar seus esforços para alcançar resultados.

As diversas concepções do poder se definiram quando as pessoas passaram a usar de força e autoridade para viabilizar sua vontade. Bertrand Russel discutiu o poder humano classificando-o em três dimensões: 1) Poder sobre seres

\footnotetext{
${ }^{6}$ MENDIETA, L. N. Sociologia de Poder. México: Universitária, 1976. p. 16.

${ }^{7}$ THOMPSON, J. B. Ideologia e Cultura Moderna. Teoria Social Crítica na era dos meios de comunicação de massa. Petrópolis: Vozes, 1995, p.39.

${ }^{8} \mathrm{O}$ que é Poder: Poder é o direito de deliberar, agir e mandar e também, dependendo do contexto, exercer sua autoridade, soberania, ou a posse do domínio, da influência ou da força. Poder é um termo de origem latina, e é definida por diversas áreas. Segundo a sociologia, poder é a habilidade de impor a sua vontade sobre os outros, e existem diversos tipos de poder: o poder social, o poder econômico, o poder militar, o poder político, entre outros. Alguns autores importantes que estudaram a questão de poder foram Michel Foucault, Max Weber, Pierre Bourdieu. As principais teorias sociológicas relacionadas ao poder são a teoria dos jogos, o feminismo, o machismo, o campo simbólico etc. Para a política, poder é a capacidade de impor algo sem alternativa para a desobediência. O Poder se expressa nas diversas relações sociais, e onde existem relações de poder, existe política, e a política se expressa nas diversas formas de poder. APPLE, M. W. Poder, significado e identidade, ensaios de estudos educacionais críticos. São Paulo: Porto Editora, 2003, p.150-173.
} 
humanos; 2) Poder sobre a matéria inerte; 3) Poder sobre formas não humanas de vida. Russel via que nenhuma dimensão, entretanto era tão complexa e propensa a tantas tensões como sobre os seres humanos. Uma de suas diversas definições: "Poder é a capacidade de dirigir ou evitar ações atuais ou futuras de outros grupos e indivíduos. " 9

Sendo que os seres humanos são agentes morais, o uso do poder pode ter contornos positivos ou negativos. ${ }^{10} \mathrm{O}$ poder possui uma eficácia produtiva, uma riqueza estratégica, e uma positividade contagiante. É justamente esse aspecto que explica o fato de que tem como alvo o ser humano, não para supliciá-lo, mutilá-lo, mas para aprimorá-lo, adestrá-lo. ${ }^{11}$

Na sua essência, o poder é: 1) A ação sobre o corpo; 2) O adestramento do gesto; 3) A regulamentação do comportamento; 4) A normatização do prazer; 5) A interpretação do discurso, com o objetivo de separar, comparar, distribuir, avaliar, hierarquizar as ações humanas.

O poder é uma realidade incontestável na história, os seres humanos têm exercido poder, estão subordinados ao poder e carecem de certas estruturas de poder para que sua sobrevivência seja equilibrada e permanente. Deus criador dos céus e da terra é o Todo-Poderoso do Universo, reina de forma legítima e capacita suas criaturas a exercerem escolhas e influencia, ao mesmo tempo estabelece limites para que as ações não sejam destruidoras nem comprometam seu reino estabelecido. Pela fé em Jesus Cristo é possível abordar a tarefa científica com a

\footnotetext{
${ }^{9}$ Por que repetir erros antigos, se há tantos erros novos a escolher? A provocação espirituosa de Bertrand Russell bem demonstra seu interesse pela vida, pela liberdade e pelo conhecimento. Bertrand Russell ingressou em 1890 na universidade de Cambridge, para estudar filosofia e lógica. Em 1901 descobriu o famoso "paradoxo de Russell", com grande repercussão no campo da lógica. Bertrand Russell ganhou reputação como um dos maiores lógicos do século 20 e um dos fundadores da filosofia analítica. Durante a Primeira Guerra Mundial, Russell dedicou-se ao ativismo político. Em consequência de seus protestos contra a guerra, foi expulso, em 1916, do Trinity College. Dois anos depois, foi condenado a cinco meses de prisão, onde escreveu "Introdução à Filosofia Matemática". Em 1920 Russell viajou para a Rússia e a seguir foi para Pequim (China), onde viveu durante um ano como professor de filosofia. Em 1927 fundou a escola experimental "Beacon Hill". Mudou-se para os Estados Unidos em 1939, para lecionar na Universidade da Califórnia. Em 1944 Russell retornou à Inglaterra, integrando novamente os quadros do Trinity College. No ano seguinte, publicou sua extensa "História da Filosofia Ocidental". Cinco anos mais tarde, foi agraciado com a Ordem do Mérito e, em 1950, ganhou o Prêmio Nobel de Literatura. Em 1958, iniciou uma campanha pelo desarmamento nuclear e, em 1962, atuou como mediador na crise dos mísseis, em Cuba, impedindo a deflagração de um conflito atômico. BETRAND, R. Bertrand Russell in 90 minutes. Rio de Janeiro: Jorge Zahar, 2003, p.12-20.

${ }^{10}$ RODRIGUES, R. O evangelho do Poder. In: STEUERNAGEL, Valdir. No princípio era o Verbo. Evangelho, Cultura e Missão. Curitiba: Encontrão, 1994. p. 129.

${ }^{11}$ FOUCAULT, Michel. Microfísica do poder. Rio de Janeiro: GRAAL, 1999. p. 186.
} 
modéstia que provém do reconhecimento das falências e limitações humanas, pois com a esperança de crescer em conhecimento da verdade.

Ao pensar no poder que resulta na ação, escolhas e relacionamento dos atos entre si, o poder pode destruir ou criar. O poder que destrói exige ascendência; requer controle absoluto. Ele destrói relacionamentos; destrói a confiança; destrói o diálogo; destrói a integridade. O poder que cria a vida, a alegria e a paz é liberdade e não escravidão, vida e não morte, transformação e não coerção. $O$ poder que cria restaura relacionamentos e concede dom da integridade a todos. $\mathrm{O}$ poder que cria é um poder espiritual, o poder que precede de Deus. ${ }^{12}$

Segundo Maquiavel ${ }^{13}$, o poder está inserido numa dinâmica em que as pessoas escolhem e outras vezes alguém escolhe por elas. O poder nunca é neutro; quem exerce a favor do que é exercido está levando em conta determinados valores que são morais, e levam em conta o destino de outros $\mathrm{O}$ poder deve considerar as necessidades pessoais e apresentar alternativas que farão diferença no contexto onde estiver sendo exercido.

O próprio poder é o valor, é um valor importante; mas não se faz aqui suposição alguma de que seja sempre e em toda parte mais importante que outros códigos de valores. O poder é, especificamente, um valor de deferência: ter poder é ser levado em conta nos atos (política) dos outros. Em situações concretas, é importante distinguir claramente entre o poder como valor e os princípios sobre os quais o poder está sendo exercido.

Uma pessoa pode ter poder sobre a riqueza (poder econômico), por exemplo, sem ocupar uma posição correspondente favorável com relação à própria riqueza - é o caso de poderosos líderes sindicais. Uma pessoa pode

${ }^{12}$ RODRIGUES, R. O evangelho do Poder. In: STEUERNAGEL, Valdir. No princípio era o Verbo. Evangelho, Cultura e Missão. Curitiba: Encontrão, 1994. p.129.

${ }^{13} \mathrm{O}$ pensamento de Maquiavel tem uma importância ímpar nos estudos políticos pelo fato de ele estabelecer uma nítida separação entre a política e a ética, bem como por deixar de lado a antiga concepção de política herdada da Grécia antiga, que visava compreender a política como ela deve ser. Nesse sentido, sua obra teórica constitui uma reviravolta da perspectiva clássica da filosofia política grega, pois o filósofo partiu "das condições nas quais se vive e não das condições segundo as quais se deve viver". Sua teoria desmascarou as pretensões morais e religiosas em matéria de política. Mas ele - ao contrário do que equivocadamente se difunde - não pretendia criar um manual da tirania perfeita. Maquiavel procurava promover uma ordem política inteiramente nova, em que os mais hábeis utilizassem a religião para governar, isto é, para arrancar o homem à sua maldade natural e torná-lo bom. Conseguiu retornar à Florença e entender-se com Lourenço de Médici, ao qual dedicou "O Príncipe", e se tornou, em 1520, historiador oficial da cidade-Estado. Nesse sentido, pode-se compreender Maquiavel como um intelectual renascentista, cujo conhecimento pretendia abarcar os mais diversos aspectos da realidade, inclusive a arte - seja teatral ou literária. BIGNOTTO, N. Maquiavel. Rio de Janeiro: Jorge Zahar Editor Ltda, 2003, p.7-11. 
controlar a distribuição do respeito sem ser respeitada - esse pode ser o caso de um editor ou publicista. E assim por diante. ${ }^{14}$

Segundo Foucault, ${ }^{15}$ um indivíduo que exerce poder sem legitimidade tende a agir a partir da força e dos referenciais (posição ou recomendação de outros, família, ou herança) de seu cargo, assim sendo, sua influência em um determinado grupo acontece a partir de determinadas imposições requeridas. Analisando o conceito do poder, percebe-se que este valor, por mais controvertido que seja, está inserido na esfera existencial humana, sem o poder o ser humano passa a ser

${ }^{14}$ LASSWELl, A.; KAPLAN, Abraham D., Poder e Sociedade. Brasília: Univers, 1999. p. 43.

${ }^{15}$ Nascido em uma família tradicional de médicos, Michel Foucault frustrou as expectativas de seu pai, cirurgião e professor de anatomia em Poitiers, ao interessar-se por história e filosofia. Apoiado pela mãe, Anna Malapert, mudou-se para Paris em 1945 e antes de conseguir ingressar na École Normale, foi aluno do filósofo Jean Hyppolite, que lhe apresentou à obra de Hegel. Em 1946 conseguiu entrar na École Normale. Seu temperamento fechado o fez uma pessoa solitária, agressiva e irônica. Em 1948, após uma tentativa de suicídio, iniciou um tratamento psiquiátrico. Em contato com a psicologia, a psiquiatria e a psicanálise, leu Platão, Hegel, Marx, Nietzsche, Husserl, Heidegger, Freud, Bachelard, Lacan e outros, aprofundando-se em Kant, embora criticasse a noção do sujeito enquanto mediador e referência de todas as coisas, já que, para ele, o homem é produto das práticas discursivas. Dois anos depois, Foucault se licenciou em Filosofia na Sorbone e no ano seguinte formou-se em psicologia. Em 1950 entrou para o Partido Comunista Francês, mas afastou-se devido a divergências doutrinárias. No ano de 1952 cursou o Instituto de Psychologie e obteve diploma de Psicologia Patológica. No mesmo ano tornou-se assistente na Universidade de Lille. Foucault lecionou psicologia e filosofia em diversas universidades, na Alemanha, na Suécia, na Tunísia, nos Estados Unidos e em outras. Escreveu para diversos jornais e trabalhou durante muito tempo como psicólogo em hospitais psiquiátricos e prisões. Viajou o mundo fazendo conferências. Em 1955, mudou-se para Suécia, onde conheceu Dumézil. Este contato foi importante para a evolução do pensamento de Foucault. Conviveu com intelectuais importantes como Jean-Paul Sartre, Jean Genet, Canguilhem, Gilles Deleuze, Merlau-Ponty, HenriEy, Lacan, Binswanger, etc. Aos 28 anos publicou "Doença Mental e Psicologia" (1954), mas foi com "História da Loucura" (1961), sua tese de doutorado na Sorbone, que ele se firmou como filósofo, embora preferisse ser chamado de "arqueólogo", dedicado à reconstituição do que mais profundo existe numa cultura - arqueólogo do silêncio imposto ao louco, da visão médica ("O Nascimento da Clínica", 1963), das ciências humanas ("As Palavras e as Coisas", 1966), do saber em geral ("A Arqueologia do Saber", 1969). Esteve no Brasil em 1965 para conferência à convite de Gerard Lebrun, seu aluno na rue d'Ulm em 1954. Em 1971, ele assumiu a cadeira de Jean Hyppolite na disciplina História dos Sistemas de Pensamento. A aula inaugural foi "a Ordem do discurso". A obra seguinte, "Vigiar e Punir", é um amplo estudo sobre a disciplina na sociedade moderna, para ele, "uma técnica de produção de corpos dóceis". Foucault analisou os processos disciplinares empregados nas prisões, considerando-os exemplos da imposição, às pessoas, e padrões "normais" de conduta estabelecida pelas ciências sociais. A partir desse trabalho, explicitou-se a noção de que as formas de pensamento são também relações de poder, que implicam a coerção e a imposição. O primeiro dos seis volumes anunciados foi publicado em 1976 sob o título "A Vontade de Saber". Em 1984, pouco antes de morrer, publicou outros dois volumes: "O Uso dos Prazeres", que analisa a sexualidade na Grécia Antiga e "O Cuidado de Si", que trata da Roma Antiga. Foucault teve vários contatos com diversos movimentos políticos. Engajou-se nas disputas políticas nas Guerras do Irã e da Turquia. O Japão é também um local de discussão para Foucault. Várias vezes esteve no Brasil, onde realizou conferências e firmou amizades. Foi no Brasil que pronunciou as importantes conferências sobre "A Verdade e as Formas Jurídicas", na PUC do Rio de Janeiro. Em 25 junho de 1984, em função de complicadores provocados pela AIDS, Foucault morreu aos 57 anos, em plena produção intelectual. FOUCAULT, M. O Sujeito e o Poder In: RABINOW, P.; DREYFUS, H. Michel Foucault: Uma trajetória filosófica para além do estruturalismo e a hermenêutica. Rio de Janeiro: Forense Universitária, 1995.p,231-249 
incompleto, tanto para aquele que o exerce quanto para o que recebe sua influência.

Nos fundamentos do poder ocorrem mudanças de uma época para a outra, com a diversidade de interesses que movem os seres humanos e os aspectos da vida aos quais atribuem importância preponderante. Esses aspectos podem ter fonte na religião, nas proezas e no prestígio militar, na força da organização profissional e no controle exclusivo de certas formas de conhecimento e qualificação, tais como as do mágico, do curandeiro tribal e do advogado. ${ }^{16} \mathrm{Com}$ esse pano de fundo, o poder é mutante, vai assumindo formas e fazendo as adequações necessárias ao seu tempo.

Com o passar dos tempos, aconteceu a mudança de poder oficial ${ }^{17}$; trata-se de uma mudança de estrutura fundamental que permitiu a realização, com certa coerência, da modificação dos pequenos exércitos do poder. Também é verdade que foi a constituição desse novo poder microscópio, capilar, que levou o corpo social a expulsar elementos como a corte e o personagem do rei. A mitologia do soberano não era mais possível a partir do momento em que certa forma de poder foi sendo exercido na sociedade. O soberano tornou-se então um personagem fantástico, ao mesmo tempo monstruoso e arcaico. ${ }^{18}$ Surge então um poder diferente, sem levar somente em conta um poder soberano, acontece a descentralização do poder, na sociedade todos são responsáveis por seu funcionamento e devem prestar contas por suas escolhas, sejam boas ou más.

\subsubsection{O Exercício do Poder}

No exercício do poder, os seres humanos têm demonstrado formas diversas de ação e esta é uma observação a ser considerada: "No exercício do poder as

\footnotetext{
${ }^{16}$ LASSWELL, Harold; KAPLAN, Abraham D., Poder e Sociedade. Brasília: Univers, 1999.

${ }^{17} \mathrm{Na}$ organização do Estado, o homem concentra seu poder sobre o homem em um único cargo oficial. O monopólio da força física de que goza esse cargo é absoluto. Pode, sem dúvida, canalizar seu poder mediante delegação específica; nos demais casos, e desde que o Estado não seja derrubado, esse poder continua à disposição da autoridade central. Nas mãos do Estado o poder adota diversas formas e no uso de suas atribuições pode proibir, matar, encarcerar, escravizar, multar. Mas as forças do Estado não têm projeções meramente negativas. O Estado se apoia nas forças integradoras da sociedade: o amor, a lealdade, a dependência recíproca, a fé religiosa, a tradição e a força do costume. SILVA, M. P. Reforma do Estado e Democracia, uma comparação entre o Brasil e a Rússia. Brasília: Editora Vestnik, 2014. p. 15.

${ }^{18}$ FOUCAULT, Michel. Microfísica do poder. Rio de Janeiro: GRAAL, 1999. p. 131.
} 
pessoas são seduzidas por imagens e posturas não convencionais”. De repente, o indivíduo manso se transforma numa figura autoritária e impertinente. O carismático conquistador que poderia fazer uso dessas habilidades para ajudar e motivar outros, passa a ser um manipulador interesseiro sem escrúpulos. Para descrever essa transformação, uma das figuras usadas é a do Leviatã, "Do Heb Lijathan, animal que se enrosca", o monstro do caos, citado na mitologia fenícia, identificado na Bíblia como um animal aquático ou réptil.

Leviatã - é tido como "um homem artificial de maior força e tamanho que o natural", em cuja proteção e defesa foi erigido. O caráter de seu poder é incondicional, irresistível, inapelável e ilimitado. Segundo Hobbes, o soberano é irresponsável: é o máximo guarda da paz e a autoridade suprema em matéria de fé, legislador, juiz supremo, tem o direito de premiar e castigar "praeter legem" e de outorgar todas as honras e dignidade. ${ }^{19}$

A figura do Leviatã representa o homem poderoso, que exerce um poder incondicional, que ultrapassa os limites humanos, um poder que não sofre nenhuma apelação, igual ao poder exercido pelos tiranos. As suas ações mesmo trazendo consequências catastróficas não são questionadas devido à força descomunal do seu poder.

Ele se apresenta como o supremo responsável pelo poder, podendo galardoar e castigar a quem quiser, esse exercício está baseado na sua força e na sua influência. Em outras palavras, o ser humano limitado e frágil, passa a assumir a forma de uma figura divina, coloca-se no lugar de um deus, conduzindo e manipulando situações a seu favor na maioria das vezes.

No mito, o ser humano afirma sua apreensão do que os estoicos denominavam "a simpatia do todo", e de seu papel e participação nesse todo. No exercício do poder, a questão do mito é muito forte, devido ao fato dos indivíduos poderosos de repente passarem a ser cultuados por seus seguidores, que se transformam em adoradores. O mito é a afirmação, carregada de emoção, do lugar do homem num mundo que tem sentido para ele.

O poder pode ser representado também como um polvo, que através de seus tentáculos consegue estar inserido nos diversos seguimentos da sociedade. Ao se referir ao primeiro sentido indicado, pode-se chamar "estratégia de poder" ao

\footnotetext{
${ }^{19}$ PAUPÉRIO, A. M. Teoria Democrática da Soberania. Rio de Janeiro: Florense Universitária, 1997. p. 55.
} 
conjunto dos meios operados para fazer funcionar ou para manter um dispositivo de poder. $^{20}$

A palavra estratégia é correntemente empregada em três sentidos. Primeiro, para designar a escolha dos meios empregados para se chegar a um fim; trata-se da racionalidade empregada para atingirmos um objetivo. Para designar a maneira pela qual um parceiro, num jogo age em função daquilo que se pensa dever ser a ação do outro, e daquilo que ele acredita que os outros pensarão ser a dele; em suma, a maneira pela qual tentamos ter uma vantagem sobre o outro. Enfim, para designar o conjunto dos procedimentos utilizados num confronto para privar o adversário dos seus meios de combate e reduzi-los a renunciar à luta; trata-se, então, dos meios destinados a obter a vitória. Estas três significações se reúnem nas situações de conforto - guerra ou jogo - onde o objetivo é agir sobre um adversário de tal modo que a luta lhe seja impossível. A estratégia se define então pela escolha das soluções vencedoras. ${ }^{21}$

Um tipo de cadeia de ações passa a ser construído no exercício do poder, diferentes grupos são formados, pessoas, leis, sociedades, culturas, religião, educação, trabalho etc. A questão nesta construção de comando passa a exercer o poder visando o bem dos indivíduos que estão relacionados naquela estrutura da sociedade.

Como se exerce o poder? Para certas pessoas, interrogar-se sobre o "como" do poder seria limitar-se a descrever seus efeitos, sem nunca os relacionar nem a causas nem a uma natureza. Seria fazer deste poder, uma substância misteriosa que, sem dúvida, se evita interrogar em si mesma por preferir não "colocá-la em questão". Neste mecanismo, que não se explicita racionalmente, suspeita-se de um fatalismo. Mas sua desconfiança não nos mostra que elas supõem que o poder é algo que existe com sua origem, sua natureza e suas manifestações. ${ }^{22}$

Exercer o poder é uma arte a ser conquistada pelos governantes, e existem alguns modelos e paradigmas na história da humanidade que podem ser seguidos. Deus, governante supremo do Universo, visando o bem maior da humanidade, enviou com amor Seu filho ao mundo, para todo aquele que nEle crer não pereça, mas tenha a vida eterna (Jo 3.16) Praticando o amor, Deus se revela para amar o ser humano. Jesus é a encarnação de Deus, exerceu um poder que visava o bem comum, a figura do próximo era muito importante para Ele. Para exercer o poder de forma justa e equilibrada deve se levar em conta o exemplo de Jesus.

O exercício do poder humano, em contraste com o poder divino, se

\footnotetext{
${ }^{20}$ FOUCALT, Michel. O Sujeito e o Poder. Rio de Janeiro: Graal. 1999. p. 31.

${ }^{21}$ FOUCALT, Michel. O Sujeito e o Poder. Rio de Janeiro: Graal. 1999. p. 30.

${ }^{22}$ FOUCALT, Michel. O Sujeito e o Poder. Rio de Janeiro: Graal. 1999. p. 36.
} 
apresenta baseado no carisma do sujeito. $\mathrm{O}$ ser humano tende a agir com poder através de sua influência na comunidade, conseguindo adeptos e por vezes impondo uma filosofia ou construindo uma imagem para agir em determinadas situações. Portanto, um poder que está além das aparências das coisas e acontecimentos cotidianos pode ser percebido pelos seres humanos, tanto em sua experiência do extraordinário quanto do estabelecimento da sua influência.

Weber demonstrou que, apesar da perda de espontaneidade, existente na rotinização do carisma, um elemento carismático continua a ser central para as instituições da ordem social estabelecida. De forma semelhante, Van Der Leuw ${ }^{23}$ mostrou que a ordem estabelecida da natureza, bem como sua espontaneidade imprevisíveis, que são vistas em acontecimentos extraordinários, podem dar aos seres humanos a impressão de um poder que está além das aparências comuns das coisas.

O governante carismático passa a ser um ícone da estrutura, o que se pretende como "fim" (propósito final, alvo a ser alcançado) relacionado com a organização; e as estruturas criadas em volta dela passam a depender do carisma do governante. Este fato traz outra consideração: sabe-se, desde Aristóteles, que a intuição intelectual direta e imediata de qualquer objeto de conhecimento não existe, isto é, não é faculdade do ser humano. O ser humano não passa a seguir uma determinada proposta de poder, ou até mesmo um governante carismático apenas por uma intuição intelectual. Toda cognição está medida pelos sentidos e se apoia iniludivelmente em representações ou imagens mentais.

O sujeito passa a seguir ou agir a partir do que está sendo apresentado para ele e, dependendo da sua índole, adere ao movimento. Pode se considerar o traficante de drogas como exemplo, pois ele exerce um poder, consegue adeptos devido a suas ações desregradas contra a sociedade e o enfrentamento contra a polícia, e ao mesmo tempo oferece condições de vida para seus seguidores. Percebe-se em outro caso, um determinado médico que desenvolva uma nova técnica cirúrgica conseguirá convencer seus correligionários a seguir as mesmas práticas porque está visando o bem da sociedade e ajudar a salvar vidas. Como se percebe, exercer poder e agir de modo que possa ser visto, nessa sequência,

${ }^{2323}$ O livro clássico de Gerardus Van Der Leeuw, Phanomenologie der Religion, publicado originalmente em 1933, em Tubingen, revisado em 1956, foi publicado em espanhol, em 1964, e reimpresso em 1975. A tradução foi de Ernesto de La Peña, publicado pelo Fondo de Cultura Económica, do México. https://periodicos.ufrn.br/cronos/article/view/3342 24112016 
permite que os seguidores surjam.

Outra tese que se apresenta: O poder sem justiça repousa sobre uma base incerta, e os seus dias estão contados. Ao se perguntar o que é justiça, a resposta não é imediata; mas é fácil de encontrar o sentido da justiça na comunidade. Basta ultrajá-la ou violá-la para que o intangível se torne real, e o indefinível evidente e eficaz em termos de autoridade e de moral aconteçam. ${ }^{24}$

Até o líder do tráfico de drogas tem que prezar por seus concidadãos, pois a partir do momento em que ele começar a agir injustamente com seus comparsas seu poder começará a ser minado. Na vida de traficar drogas, muitos morrem por seu líder, estão presos, e não delatam, mas a partir do momento em que se constatar vantagens para uns em detrimento de outros, tudo se desmorona.

É claro que dinheiro, cultura e violência não são as únicas fontes do poder no cotidiano, o qual não é bom nem mau. Ele é uma dimensão de todos os relacionamentos humanos. É, na verdade, a reciprocidade do desejo e, como os desejos humanos são infinitamente variados, tudo o que poder satisfazer o desejo de outra pessoa é uma fonte de poder em potencial.

Pode se pensar também na questão pastoral, que sofre muito mais exigências. O ministério pastoral é construído a partir de postulados de justiça, que foi um fundamento dos ensinos de Jesus: "Bem-aventurado os justos". Ao ser praticada, essa justiça, o reconhecimento e a legitimidade do ministério serão evidenciados e, a partir do momento em que essa "cadeia" (conjunto de princípios, doutrinas e normas cristãs) for quebrada, o exercício do poder será comprometido.

Moisés é um modelo bíblico. Ainda que tivesse enorme poder e responsabilidade como líder dos israelitas, foi descrito na Escritura como “...mui manso, mais do que todos os homens que havia sobre a terra" (Nm 12,3). Ele era guiado pelo ministério, intercedendo diante de Deus a favor de seus irmãos, pedindo perdão pela rebelião deles e cuidando das necessidades do povo antes das suas próprias. Ademais, a História demonstra a falácia da ideia de que só porque alguém é devoto será também um governante justo e sábio.

Moisés exerceu o poder tendo em vista o benefício da sua gente, várias vezes em detrimento de suas próprias vantagens, mas nem sempre tem sido assim:

\footnotetext{
${ }^{24}$ KAPLAN, H. D.; LASSWELL, A. Poder e Sociedade. Brasília: Univers, 1999. p. 39.
} 
historicamente muitos líderes buscam seus próprios interesses.

Por exemplo, o líder que forjou a Alemanha unificada a partir de um aglomerado de estados menores. Otto Von Bismarck-Schönhausen ${ }^{25}$ foi um cristão comprometido com a fé cristã, que lia regularmente a Bíblia, falava abertamente de sua devoção por Deus, e alegava a direção divina em resposta a orações. "Se eu não fosse um cristão, não serviria ao rei nem por mais uma hora", declarou um dia. Ainda assim, Bismarck foi também inescrupuloso arquiteto do Deutschland Uber Alles (Alemanha acima de tudo), uma cosmovisão chauvinista que fundamentou duas guerras mundiais.

Os historiadores descrevem Bismarck como um mestre maquiavélico da duplicidade política, especializado em sangue e ferro. ${ }^{26}$ Neste caso, a religião foi o palco para o exercício da maldade que estava guardada no coração desse homem, ele aproveitou as oportunidades concedidas pelo rei e os espaços oferecidos pela religião para executar seu plano destruidor.

O entendimento cristão de poder é de que este é encontrado mais frequentemente na fraqueza. Esse paradoxo tem sido um espinho na carne dos tiranos. O ensino cristão de que o ser humano é vulnerável às tentações do poder tem feito com que democracias e nações livres ergam restrições e estabeleçam equilíbrio de poder em suas estruturas.

\footnotetext{
${ }^{25}$ Otto Von Bismarck, o chanceler de ferro, foi o estadista mais importante da Alemanha do século 19. Coube a ele lançar as bases do Segundo Império, ou $2^{\circ}$ Reich (1871-1918), que levou os países germânicos a conhecer pela primeira vez na sua história a existência de um Estado nacional único. Para formar a unidade alemã, Bismarck desprezou os recursos do liberalismo político, preferindo a política da força. Em 1862 Bismarck foi nomeado primeiro-ministro e ministro dos Negócios Estrangeiros de Guilherme I, rei da Prússia. Bismarck reergueu aquele ideal, recorrendo à política que alternava "entre o chicote e o pão-doce", lançando mão da guerra e das negociações diplomáticas, conforme a sua estratégia determinava. Quando morreu o rei da Dinamarca, Frederico $7^{\circ}$ (1863), entrou em questão a sucessão dos ducados de Schleswig-Holstein. Bismarck articulou para levar a Áustria a uma guerra contra a Dinamarca, na qual foi vencida. Em 1865, foi organizada uma administração austro-prussiano nos dois ducados e Lauenburg foi anexado à Prússia. Bismarck recebeu o título de conde. Aproveitando as discórdias entre Berlim e Viena, Bismarck levou as negociações ao campo de batalha. Isolou a Áustria e convenceu a França e a Itália a ficarem do seu lado. Em janeiro de 1871, no Palácio de Versalhes, foi proclamado o Segundo Império Alemão. Bismarck foi nomeado chanceler e recebeu o título de príncipe. O chanceler de ferro recolheu-se à propriedade da família na Prússia, onde morreu aos 83 anos, após escrever suas memórias. MORA-ANDA, E. História dos Ideais. Brasília: Thesaurus, 2006. p. 1725.
}

${ }^{26}$ HORTON, Michael. Religião do Poder. São Paulo: Editora Cultura Cristã, 1998. p. 25. 


\subsection{O poder em perspectivas midiáticas}

Quando se examina a literatura relativa aos conceitos de ideologia e as explicações dos fenômenos ideológicos, é difícil escapar do sentimento de que ela se+ja dominada por uma grande confusão. As definições do termo são muito variáveis de um autor para outro, e as explicações do fenômeno utilizam-se de princípios paradoxos. Tem-se a impressão de que a mesma palavra serve para uma descrição de uma variedade de fenômenos, e não de um fenômeno único, de que as teorias da ideologia se opõem entre si sobre um objeto que definem de maneira diferente uma da outra e de que o importante corpus que constituem tem, com frequência, a aparência de um diálogo infundado. ${ }^{27}$

É fundamental para um ambiente de comunicação religiosa estudar-se a respeito das formações ideológicas e suas construções temáticas, devido ao fato do comunicador midiático, padre ou pastor, ser na maioria das vezes um formador de opinião, alguém que está de certa forma transmitindo uma ideologia ou, por assim dizer, apresentando um conjunto de crenças.

Sem dúvida, faz falta uma reflexão crítica pastoral sobre o significado dessa ação no contexto socioeconômico, político e cultural da América Latina e uma análise a respeito do papel que compete aos líderes religiosos desempenharem junto à comunidade da fé. Uma reflexão que aborde profundamente os diferentes aspectos, examinando os problemas pessoais e estruturais das pessoas, das famílias, das comunidades, das cidades e países, assim como os problemas profundos da existência (vida, culpa, morte etc.). Uma reflexão que levante a pergunta de como introduzir o evangelho na vida íntima dos indivíduos.

Carlos Grzybowski relata o seguinte: O mundo vive hoje sob uma quase total hegemonia da ideologia econômica neoliberal. Certamente tal influência ideológica não se restringe aos âmbitos da economia de mercado, mas direta $\mathrm{e}$ indiretamente a mesma vai penetrando em outras áreas da convivência humana e modificando os princípios relacionais, vai sutilmente levando a sociedade a um pensar de maneira uniforme e inquestionável visto que tem a "aprovação" da maioria.

A ideologia neoliberal ${ }^{28}$ tem por marca dominante a competitividade

\footnotetext{
${ }^{27}$ RAYMOND, B. A Ideologia. São Paulo: Ática, 1989. p. 25.

${ }^{28}$ Neoliberalismo é uma redefinição do liberalismo clássico, influenciado pelas teorias econômicas
} 
levando em conta a subjugação dos menos capacitados e o reducionismo do sentido de existir e a capacidade de ter e de acumular riquezas, limitando as possibilidades apenas para um grupo de favorecidos..

O comunicador midiático deve estar a par do desenvolvimento e da formulação das ideias relacionadas e suas origens, pois a problemática da ideologia tem lugar nas bases e nos motivos. As análises ideológicas de que fala Mannheim consiste precisamente em apresentar de onde vem e o que se diz nas origens de seus conteúdos. Aborda o poder incluso que deve ser revisado e a tese de que a gênesis de uma proposição precisa de importância para sua verdade.

Há, segundo ele, uma forma legítima do argumento que formaria parte das formulações da sociologia do conhecimento. ${ }^{29}$ Precisa-se saber o ponto de partida das ideias, quais são os motivos básicos para que elas estejam sendo implementadas. A religião é um palco propício para manipulação e jogo de poderes; de forma subjetiva e com interesses dúbios podem ser inseridos no ambiente da fé de tal maneira que camufle suas verdadeiras intenções.

De forma objetiva, pensar sobre ideologia é tentar diagnosticar um sistema de crenças que uma determinada coletividade tem vivido de acordo com seus conceitos e normas. Precisa-se se levar em conta os aspectos culturais e sociais dos sujeitos e suas capacidades de participar dos eventos e situações criadas a partir de suas decisões.

Alguns teóricos apresentam diferentes enfoques a respeito do conceito de "ideologia" 30 . Segundo os dados mais conhecidos, o termo começa a ser usado no

neoclássicas e é entendido como um produto do liberalismo econômico clássico. O neoliberalismo pode ser uma corrente de pensamento e uma ideologia, ou seja, uma forma de ver e julgar o mundo social ou um movimento intelectual organizado, que realiza reuniões, conferências e congressos. Esta teoria, que foi baseada no liberalismo, nasceu nos Estados Unidos da América e teve como alguns dos seus principais defensores Friedrich A. Hayeck e Milton Friedman. Na política, neoliberalismo é um conjunto de ideias políticas e econômicas capitalistas que defende a não participação do estado na economia, onde deve haver total liberdade de comércio, para garantir o crescimento econômico e o desenvolvimento social de um país. O neoliberalismo defende a pouca intervenção do governo no mercado de trabalho, a política de privatização de empresas estatais, a livre circulação de capitais internacionais e ênfase na globalização, a abertura da economia para a entrada de multinacionais, a adoção de medidas contra o protecionismo econômico, a diminuição dos impostos e tributos excessivos etc. MORAIS, R.C. Neoliberalismo, de onde vem, para onde vai. São Paulo: SENAC, 2001. p. 14-16.

${ }^{29}$ ROGERS, Juan D. Ideologia e Conhecimento da Realidade Sócio-Econômica-Política. Curitiba: Editora Encontro, 1986. p. 196.

${ }^{30}$ Ideologia é um conjunto de ideias ou pensamentos de uma pessoa ou de um grupo de indivíduos. A ideologia pode estar ligada a ações políticas, econômicas e sociais. O termo ideologia foi usado de forma marcante pelo filósofo Antoine Destutt de Tracy. O conceito de ideologia foi muito trabalhado pelo filósofo alemão Karl Marx, que ligava a ideologia aos sistemas teóricos (políticos, morais e sociais) criados pela classe social dominante. Ideologia democrática: surgiu em Atenas, 
final do século XVIII por um determinado círculo de pensamento ilustrado francês. A citação mais conhecida é a de Destutt de Tracy ${ }^{31}$ que denomina a "ideologia" como uma ciência de ideias que explica as origens das mesmas e dos mesmos estilos em que a mecânica de Newton dava conta das partículas de materiais. $^{32}$

A ideologia é inseparável do que se considera conhecimento. Na maioria dos casos, o conceito de ideologia serve para distinguir o que é o verdadeiro conhecimento científico. É interessante notar que isso concebem visões tão desiguais como o marxismo estruturalista de Althusser e a preocupação cientificista mais positivista de Bunge ${ }^{33}$. O fato de reconhecer que as relações sociais se filtram no processo mesmo de conhecimento é também o ponto de partida do trabalho de Mannheim e a motivação para convertê-los em matérias de uma disciplina específica: a sociologia do conhecimento ${ }^{34}$. Vários sociólogos e filósofos trabalharam a partir de postulados construídos a partir dessas ideologias.

\subsubsection{A sedução do poder midiático}

Outra questão a ser considerada a respeito do poder, diz respeito à sedução, os encantos derivados do poder que podem se tornar uma armadilha. A sedução

\footnotetext{
na Grécia Antiga, e possui como ideal a participação dos cidadãos na vida política. EAGLETON, T. Ideologia. São Paulo: Boi Tempo Editorial, 1997. p. 16.

${ }^{31} \mathrm{O}$ conceito ideologia foi criado pelo francês Antoine Louis Claude Destutt de Tracy (17541836). Este filósofo o empregou pela primeira vez em seu livro "Elementos de Ideologia", de 1801. Para designar o "estudo científico das ideias". Destutt de Tracy usou alguns métodos e teorias das ciências naturais (física e biologia basicamente) para compreender a origem e a formação das ideias (razão, vontade, percepção, moral, entre outras) a partir da observação do indivíduo em interação com o meio ambiente. EAGLETON, T. Ideologia. São Paulo: Boi Tempo Editorial, 1997. p. 18.

${ }^{32}$ ROGERS, Juan D. Ideologia e Conhecimento da Realidade Sócio-Econômica-Política. Curitiba: Editora Encontro, 1986. p.196.

${ }^{33}$ Carlos Octavio Bunge como adepto da corrente de pensamento cientificista, o que pode ser explicado com base não apenas em "Nossa América", mas em outras obras. Bunge não pode ser classificado como um intelectual puramente positivista, uma vez que buscou outros aportes da ciência para fundamentar suas teorias, como, por exemplo, o darwinismo social, o evolucionismo e o biologismo, ideais fundamentais para a definição de um novo nacionalismo como sendo um conjunto de símbolos e valores de identidade. Carlos Bunge foi advogado, professor, literato, estudioso de direito, de educação e de sociologia e, apesar de ter nascido no ano de 1875, acabou sendo incluído na Geração de 80 , devido à sua precoce maturidade intelectual. GREJO, C.B.; BUNGE, C.O.; INGENIEROS, J. Entre o científico e o político, pensamento racial e identidade nacional na argentina (1880-1920). São Paulo: Unesp, 2009. p.131.

${ }^{34}$ ROGERS, Juan D. Ideologia e Conhecimento da Realidade Sócio-Econômica-Política. Curitiba: Editora Encontro, 1986. p.196.
} 
do poder pode separar o mais resoluto dos cristãos da verdadeira natureza da fé cristã, que é servir aos outros. É difícil permanecer em pé num pedestal e lavar os pés dos que estão embaixo. Foi essa mesma tentação do poder que levou ao primeiro pecado.

O desejo de dominar, ser reconhecido, ser importante e se destacar dos demais atormenta o ser humano no mais recônditos de seus pensamentos. Numa ambição desenfreada, caminha-se para conquistar, exercer domínio sobre outros. Não que seja errado ter ambição, mas essa condição precisa ser bem estabelecida para não gerar desequilíbrios das partes envolvidas.

Uma tendência forte para aqueles que exercem o poder é agir a partir da repressão. Uma primeira resposta que se encontra consiste em dizer: o poder é essencialmente repressivo. O poder é o que reprime a natureza, os indivíduos, os instintos, uma classe. Quando o discurso contemporâneo define repetidamente o poder como sendo repressivo, isto não é uma novidade.

Em todo caso, ser órgão de repressão é, no vocabulário atual, o qualificativo quase onírico do poder. Não será, então, que a análise do poder deveria ser essencialmente uma análise dos mecanismos de repreensão? ${ }^{35}$ Não o poder na sua essência não é nem deve ser destinado para o mal. Necessariamente o poder não precisa passar pela repressão, pois quando este visa o bem comum encontrará legitimidade em seus atos, consequentemente virá o apoio dos comandados e todas as "ferramentas" (instrumentos sociais) para ser executado.

Quando se analisa o poder somente no campo da repressão, anula-se a participação comunitária, pois o modelo da repressão é o da estratégia, o modelo de guerra, custe o que custar para que o fim seja alcançado. Outro modelo proposto é o da participação, o governo existe, o poder ocorre com legitimidade e apoio das partes envolvidas.

Pois, se é verdade que no centro das relações de poder e como condição permanente de sua existência há uma "insubmissão" e liberdade essencialmente renitentes, não há relação de poder sem resistência, sem escapatória ou fuga, sem inversão eventual; toda relação de poder implica, então, pelo menos de modo virtual, uma estratégia de luta, sem que para tanto venham a se sobrepor, a perder sua especificidade e finalmente a se confundir. ${ }^{36}$

\footnotetext{
${ }^{35}$ FOUCAULT, Michel. Microfísica do poder. Rio de Janeiro: GRAAL, 1999. p. 175.

${ }^{36}$ FOUCAULT, Michel. Microfísica do poder. Rio de Janeiro: GRAAL, 1999. p.176.
} 
O domínio ${ }^{37}$ tem sido um fator decisivo na história da humanidade, com força aquele que exerce o poder se imporá sobre aqueles que se opõem e o próprio grupo dominado se levantará em determinadas situações a favor dos opressores. No mesmo sentido, Mendieta diz que o poder é: A capacidade e autoridade para dominar os homens, refreá-los e controlá-los, obter sua obediência, cortar sua liberdade e enclausurar suas atividades em direções determinadas. ${ }^{38}$

Uma sociedade dominada de forma coletiva reage de forma diferente, o grupo social tende a se acomodar com as propostas apresentadas pelos dominadores. Percebe-se isto nos países que são dominados por governantes tiranos e autoritários, estabelece-se um medo coletivo, de pensar, reagir, ou buscar outra alternativa. De repente, a morte passa a ser uma opção real, e fugir da morte passa a ser um desafio de cada dia. Não se pensa mais no bem comum, ou na sociedade como um todo, o ponto em questão é a sobrevivência diária.

Quando o domínio é sobre alguns indivíduos, a reação é diferente, aqueles que não são dominados exercem uma pressão invisível sobre os explorados. Essa situação acontece devido a liberdade apresentada, pelas perspectivas de vida usufruídas por outros, que não estão enquadrados no modelo opressor. A liberdade passa a ser um ideal.

O poder perante outros é o exercício da vontade nas relações humanas, geralmente vem acompanhado com postulados religiosos, políticos, econômicos e resulta em ações das mais variadas. Num contexto sociológico, poderia até se dizer que no "jogo do poder" (prática dos comandos) alguns são beneficiados, outros, não. Nunca o poder é exercido num vazio neutro ou numa "moralidade abstrata" (um contexto onde não existe lei), sempre haverá situações onde o poder estará inserido.

Nas relações de poder e na comunicação as capacidades objetivas não devem, então, ser confundidas. O que não significa que se trata de três domínios separados; e que haveria, de um lado, o domínio das coisas, da técnica finalizada, do trabalho e da transformação do real, e do outro, o dos signos, da comunicação, da reciprocidade e da fabricação do sentido. Enfim, o da dominação dos meios de

\footnotetext{
${ }^{37}$ Domínio, (Do lat. dominiu.) Substantivo, masculino. 1. Dominação, autoridade, poder, posse, senhorio.

${ }^{38}$ MENDIETA, N. L. Sociologia de Poder. México: Universitária, 1976. p. 16-17.
} 
coação, de desigualdade e de ação dos homens sobre os homens. ${ }^{39}$

Nas relações de poder, o domínio se torna evidente, e por incrível que pareça o ser humano é o agente moral que exerce domínio, sem isso ele perde sua moralidade. Seus domínios serão mais ou menos abrangentes, dependendo de suas capacidades. Deus tem dado capacidades ao ser humano, este, em determinados casos, tem usado para o bem comum, em outros, para seus próprios benefícios. Tem-se por consequência, quatro concepções de poder: 1) dominação, 2) força, 3) influência, 4) controle. Essas concepções são igualmente inexatas, ou que não significa que sejam maléficas, pois dependem do contexto que serão exercidas e do caráter daquele que atua. Analisando a realidade social de nosso tempo, conclui-se que quando, em efeito, o poder leva implícito o domínio, são simples atos administrativos de melhoramento social aos que não se opõem. ${ }^{40}$

É um mal-entendido comum dizer que o poder é inerentemente "ruim" e que a análise do discurso é por definição uma análise crítica. Isso é, contudo, uma concepção, bastante limitada, se não tendenciosa, de poder. O poder, obvia e trivialmente, pode ser usado para muitos propósitos neutros ou positivos, como quando pais e professores educam crianças, a mídia que nos informa ou policiais que nos protegem ou políticos que nos governam e os médicos que nos curam, cada um com seus recursos. ${ }^{41}$

Ainda por análise do domínio, o ser humano domina a natureza (podendo inclusive destruí-la), domina os animais (através da domesticação e da destruição), domina outros seres humanos (através da força e também da sutileza), com habilidades das mais diversas. Neste domínio generalizado das espécies, o ser humano se consolida como agente moral, segundo Mindieta, pela possibilidade, porque a consideramos mais exata, pois ao próprio tempo que indica a contingência do poder expressa sua realidade específica porque o poder não é mais que uma "possibilidade" reiterada a cada momento, possibilidade que, de um instante a outro, pode falhar e então ser derrubada. ${ }^{42}$

Analisando com Weber: O poder é uma possibilidade, uma chance de exercer domínio, ou uma oportunidade para que suas ideias e ações prevaleçam sobre outros, onde o saber exerce uma grande influência. Já Foucault analisa de outro ponto de vista, abordando o assunto de forma aberta e mais reflexiva.

\footnotetext{
${ }^{39}$ FOUCALT, Michel. O Sujeito e o Poder. Rio de Janeiro: Graal. 1999. p. 46.

${ }^{40}$ MENDIETA, N. L. Sociologia de Poder. México: Universitária, 1976. p.17.

${ }^{41}$ DIJK, TEUN A. VAN. Discurso e poder. São Paulo: Editora Contexto, 2008. p. 27.

${ }^{42}$ MENDIETA, N. L. Sociologia de Poder. México: Universitária, 1976. p.18.
} 
Portanto, o problema não é constituir uma teoria do poder. Todos seres humanos são iguais, e depois, o que acontece? O resultado das teorias, a invasão histórica para um, os acontecimentos mítico-jurídico para outros, mas sempre há a ideia de que, a partir de um momento, as pessoas não têm mais direitos e então surge o poder.

Se o objetivo for construir uma teoria do poder, haverá sempre a necessidade de considerá-lo como algo que surgiu em um determinado ponto, em certo momento, de que se deve fazer a gênese e depois a dedução. Mas se o poder é na realidade um feixe aberto, mais ou menos coordenado (e sem dúvida mal coordenado) de relações, então o único problema é munir-se de princípios de análise que permita uma analítica relação das forças de poder. ${ }^{43}$

Para analisar o poder não se pode enquadrá-lo dentro dos dogmas humanos, esses tendem a ser preconceituosos e tendenciosos, levando em conta o parecer do analista e do pesquisador. O exercício do poder não é simplesmente uma relação entre "parceiros" individuais ou coletivos; é um modo de ação de alguns sobre outros, que não se pode padronizar como ações voltadas para o exercício do mal. O que quer dizer, certamente, que não há algo como o "poder" ou "do poder" que existiria globalmente, maciçamente ou em estado difuso, concentrado ou distribuído: só há poder exercido por "uns" sobre os "outros”, o poder só existe em ato, mesmo que, é claro, se inscreva num campo de possibilidade esparso que se apoia sobre estruturas permanentes. ${ }^{44}$

Onde houver poder, ele é exercido. Ninguém é, propriamente falando, seu titular, e, no entanto, ele sempre se exerce em determinada direção para o bem ou para o mal, com uns de um lado e outros do outro lado; não se sabe ao certo quem o detém; mas se sabe certamente quem não o possui. ${ }^{45}$ Quando este for designado da forma correta, aqueles que estiverem envolvidos na questão serão beneficiados, quando for exercido de forma contrária ao bem, os resultados serão catastróficos.

Outra questão a ser analisada é que o poder não deve ser usado apenas para dominar, mas também para servir, ou simplesmente para manter em ordem, estabelecido de acordo com consenso geral e, então, não se pode falar de dominação. Outras vezes, os governantes se veem obrigados a impor não só a

\footnotetext{
${ }^{43}$ FOUCAULT, M. Microfísica do poder. Rio de Janeiro: GRAAL, 1999. p. 248.

${ }^{44}$ FOUCAULT, M. O Sujeito e o Poder. Rio de Janeiro: Graal. 1999. p. 56.

${ }^{45}$ FOUCAULT, M. Microfísica do poder. Rio de Janeiro: GRAAL, 1999. p. 75.
} 
vontade, mas se expressar numa assembleia legislativa mediante leis de toda uma aprovação, e não são raros os casos em que deixam de dominar, em que tenham de fazer uma verdadeira retificação de seus desígnios quando suscitam oposições que ameaçam romper o equilíbrio do Estado. ${ }^{46}$

\subsubsection{A mídia como "quarto poder"}

Outra forma do poder ser analisado é o que acontece pela influência cognitiva sobre determinados grupos sociais. Atualmente se conceitua "O Quarto Poder" como o poder escrito, o poder da imagem, o poder da influência sobre o grupo maior, que, de maneira sutil, estabelece seus ideais e desenvolve uma forma de pensar pela sociedade que o aceita, e, na maioria das vezes, aceita sem dar-se conta disto. Para ilustrar, percebe-se o efeito da televisão ${ }^{47}$ na sociedade brasileira. Os membros dessa sociedade sem se darem conta seguem os pressupostos propostos pela televisão no linguajar, na moda, nos valores, na religião por ela apresentada, resultando numa sociedade fragmentada, que vive de acordo com as máximas televisivas e seus jargões pertinentes.

O conceito de jornalismo como "quarto poder" surgiu no contexto das revoluções liberais, isto é, da luta da burguesia contra o Absolutismo e o poder da nobreza, especificamente na Inglaterra, ainda no final do século 18. O ideal liberal iluminista pressupunha, além da liberdade de expressão individual, uma imprensa

\footnotetext{
${ }^{46}$ MENDIETA, N. L. Sociologia de Poder. México: Universitária, 1976. p.17.

${ }^{47}$ A televisão está presente na vida das pessoas. Como meio de comunicação, ela traz as mais variadas informações que inconscientemente os cidadãos captam. São valores e ideologias cultuadas. Funcionando muitas vezes como ditadora de regras, estilos e modas. O sociólogo e historiador João Ramos Batanolli ressalta que a televisão tem seus pontos positivos e negativos. O lado positivo é pouco usado. "Ela exerce um efeito na sociedade. Os assuntos que passam na TV são os que são vividos, porém gera banalização da violência, morte, guerra, entre outros", afirma. As pessoas ficam tão acostumadas com o que é repassado, ver alguém morrer em sua frente se tornou algo normal. A violência é uma das principais notícias hoje trazidas nos telejornais que fisgam a atenção das pessoas. "O povo gosta de ver tragédia", explica Batanolli. De acordo com o sociólogo, a influência da televisão depende do senso crítico do telespectador. Hoje, a grande maioria se posta em frente a um aparelho de forma passiva, para distração. Além disso, existe uma articulação do poder econômico, focando no consumismo, não apenas em propagandas, como também em novelas. "Ela condiciona as pessoas a comprar", conta. Os desenhos animados que prendem as crianças podem acarretar alguns transtornos, como ansiedade, violência, consumismo e torna um adulto sem senso crítico. "A qualidade do desenho animado está cada vez mais perdendo o senso ético, como estético. Os personagens são psicóticos, ou possuem algum poder especial. Eles imprimem na mente infantil a competição, ser vitorioso com a dor do outro", diz Batanolli. ACORDI, Ana. A influência da televisão na vida das pessoas. Criciúma: SATC Educação e Tecnologia, 2012. p. 1.
} 
independente, livre da censura do Estado, formadora da opinião pública e exercendo o papel de "contra poder" em relação aos três poderes concebidos por Montesquieu - o Executivo, o Legislativo e o judiciário. Muita coisa mudou, no entanto, nos últimos trezentos anos.

O desenvolvimento tecnológico e a conformação dos sistemas econômicos fizeram com que as sociedades do século 21 se tornassem muito mais complexas do que aquelas dos séculos 18 e 19. Grande parte da comunicação humana foi, aos poucos, sendo intermediada por tecnologias e instituições. Na antiga visão da imprensa como "quarto poder" sua independência era entendida como independência do Estado e seu vínculo com o poder econômico era considerado apenas parte da ordem natural das coisas.

Atualmente, nada pode ser mais distante da realidade. A mídia, ou a indústria da comunicação, apesar de eventuais crises financeiras localizadas, transformou-se num dos principais negócios das últimas décadas. Um exemplo de concentração da propriedade no mundo globalizado, o setor está reduzido a uns poucos megagrupos privados que tendem, cada vez mais, a controlar o que se vê, se ouve e se lê.

No Brasil, uma dezena de grupos familiares empresariais, alguns associados a conglomerados multinacionais, controlam praticamente todo o fluxo da informação, do entretenimento, da publicidade e, mais recentemente, da telefonia fixa e móvel. Dessa forma, a "imprensa" se transformou em conglomerados multimídia que constituem, eles próprios, poderosos atores, tanto econômicos quanto políticos.

No novo contexto, o antigo papel de "quarto poder" independente atribuído à imprensa pelo liberalismo simplesmente não existe. Até mesmo a censura, motivação inicial da defesa da liberdade de expressão contra o absolutismo, passou a ser exercida, de forma mais ou menos explícita, dentro dos próprios conglomerados privados produtores de jornalismo. Ao lado de outras atividades anteriormente consideradas exclusivas do Estado, a censura também está sendo privatizada. $^{48}$

Ortega e Gasset ${ }^{49}$ expõe um conceito parecido ao de Hauriou, pois,

\footnotetext{
${ }^{48}$ SODRÉ, N. W. História da imprensa no Brasil. São Paulo: Mauad, 1999. p. 391.

${ }^{49}$ Doutor em Filosofia pela Universidade de Madri, foi nomeado, em 1910, catedrático de Metafísica desta universidade. Seus artigos e publicações sobre temas filosóficos e políticos
} 
segundo este ilustre escritor, o poder: "é uma espécie de emanação ativa, energética da opinião pública, no qual afloram os demais usos e vigências de que elas se nutrem. Um fato social produto de interações individuais e grupais; e como tal, aparece dotado de vigência: tem a possibilidade coativa. E potencial que se impõem. É a mais alta expressão do controle social”. Ideias estas que se baseiam em uma especulação pura, complemente afastada de uma realidade da maioria dos países do mundo em que o poder deixa muito a ser "emanação" da opinião pública. $^{50}$

A classe ideológica totalitária no poder é o poder de um mundo reinvertido: quanto mais ela é forte, mais ela afirma que não existe, e a sua força serve-lhe acima de tudo para afirmar a sua inexistência. Ela é modesta nesse único ponto, porque a sua inexistência oficial deve também coincidir com o desenvolvimento histórico, que simultaneamente se deveria ao seu infalível comando. Exposta por toda a parte a burocracia deve ser a classe invisível para a consciência, de forma que toda a vida social se torna demente. A organização social da mentira absoluta decorre desta contradição fundamental. ${ }^{51}$

Em "A sociedade de consumo", de $1970^{52}$, Baudrillard debruça-se mais diretamente sobre o tema do consumo, especialmente em sua ligação com os meios de comunicação de massa. Para ele, a universalização elencada caracteriza a sociedade de consumo, que retalham o real, criando um sistema de leitura do mundo transformado em sistema de signos. Os media uniformizam o real, diluindo o seu caráter vivido, ou seja, as suas multiplicidades e contradições. Em seu lugar, põem o universo múltiplo dos meios de comunicação mutuamente homogêneos enquanto tais, significando-se e referendando-se reciprocamente uns aos outros.

Esta visão da sociedade de consumo é muito parecida com a da "Sociedade do espetáculo", de Guy Debord, e de sua crítica ao fim da experiência vivida em prol da representação, de imagens desligadas da vida, de uma "relação social mediatizada entre pessoas por imagens", 53 já que as próprias imagens, ao se

tiveram um impacto fundamental nas elites intelectuais e políticas espanholas do primeiro terço do século XX. Sua preocupação com as questões políticas e sociais refletiu-se em sua atividade como articulista, primeiro em El Imparcial e depois em El Sol, diário que ele mesmo fundou. Também participou na criação de revistas de opinião como España (1915) e La Revista de Occidente (1923), a partir das quais divulgou as tendências filosóficas. MEDINA, J. Ortega y Gasset no exílio português. Centro de História: Universidade de Lisboa, 2004. p,20-26

${ }^{50}$ MENDIETA, N. L. Sociologia de Poder. México: Universitária, 1976. p. 16.

${ }^{51}$ DEBORD, G. A Sociedade do Espetáculo. São Paulo: Editora Verso, 1990. p. 23.

${ }^{52}$ BAUDRILLARD, J. A sociedade de Consumo. Lisboa (Portugal): 2007. p. 20.

${ }^{53}$ BAUDRILLARD, J. A sociedade de Consumo. 2007. p. 209 
tornarem especializadas, adquirem autonomia sobre o concreto. Assim, como corolário do modo de produção capitalista, a linguagem do espetáculo é constituída por signos da produção reinante, que são ao mesmo tempo o princípio e a finalidade última da produção.

A crença na onipotência do pensamento, característica dos "povos primitivos", manifesta-se na sociedade de consumo por meio da crença na onipotência dos signos, vivenciada no cotidiano, que é uma esfera imanente, privada e fechada sobre si mesma, em contraposição à esfera pública, transcendente, autônoma e abstrata do político, do social e do cultural.

Vê-se assim uma distinção entre as esferas pública e privada, e o aparecimento do cotidiano como decorrente do fortalecimento desta última. O cotidiano é o lugar que possibilita o consumo por ser um sistema coerente, repetitivo e banal, pois ele é fundado sobre o privado e a liberdade formal do indivíduo.

Por estar dissociado do mundo externo, ou daquilo que o autor chama de "real", o sujeito que vive tal cotidiano não consegue lançar um olhar objetivo sobre a totalidade, contentando-se com interpretações parciais. Os meios de comunicação desempenham um papel primordial na manutenção do cotidiano vivo, pois a banalização produzida por suas imagens e mensagens, que transformam toda a informação política, cultural e histórica em fatos espetaculares e insignificantes, criam uma sensação de segurança, constituindo-se como um álibi. Nas palavras de Cajueiro: "a imagem, o signo, a mensagem, tudo o que 'consumimos', é a própria tranquilidade selada pela distância em relação ao mundo, o que ilude, mais do que compromete, a alusão violenta ao real”, ${ }^{, 54}$.

O desafio é apresentar a mensagem real e verdadeira, não manipular, ter como meta principal a verdade, para agir dessa forma precisa-se do conteúdo do Evangelho de Jesus Cristo, essa sim é a verdade que liberta.

\subsubsection{O poder das instituições midiáticas}

O papel das instituições midiáticas é fundamental e seus produtos estão em

\footnotetext{
${ }^{54}$ CAJUEIRO, S.T. A Sociedade de Consumo, Os media e a comunicação nas obras iniciais de Jean Baudrillard. Revista Galáxia, São Paulo, jun 2011, n. 21, p. 125-136.
} 
todas as esferas da sociedade, é difícil imaginar uma vida sem livros, jornais, rádio, televisão, cinema, internet e os inúmeros recursos da comunicação global. Os personagens que se apresentam nos filmes e no cotidiano da televisão se tornam protagonistas e servem de referência para os cidadãos.

A música popular, os esportes e outras atividades, sem deixar de lados as atividades religiosas midiáticas, são mantidas pelas instituições e contam com apoio financeiro para que sua influência aumente e sua projeção tenha maior alcance.

O aparato institucional de comunicação se constitui não só pelos canais de difusão, mas também como um referencial e podem ser usadas pelo exercício do poder. Em virtude dessa capacidade, as formas simbólicas podem ser empregadas em busca de interesses variados. Assim, uma informação pode ser usada pelos agentes do estado para manipular o povo em determinada situação. Por exemplo, afirma-se que para chamar ou desviar a atenção do povo para um problema político, basta anunciar uma guerra, uma catástrofe ou a morte de um personagem famoso da sociedade. Em suma, a informação midiática pode ser usada para distorcer os fatos. Pode-se dizer que os aparatos de comunicação podem ser usados para o uso inadequado do poder.

Com o desenvolvimento dos veículos de comunicação, novas formas têm surgido, e uma nova conceituação do poder. A influência se torna maior, o alcance é sem fronteiras, o cidadão recebe o impacto da comunicação no seu próprio espaço geográfico e de tempo; assim se consolida o poder ultrapassando as distâncias.

A mensagem escrita comunica e os textos escritos e impressos e a voz gravada nos filmes tornam possível a acessibilidade. Com o passar do tempo, o poder se consolida e a garantia de que nada se perderia com as gravações. Alguns dos mais importantes desenvolvimentos na era da informação e mídia se transformaram em instrumentos de poder ${ }^{55}$.

Atualmente, o texto escrito pode ser reproduzido por muitos e ultrapassar as barreiras culturais, geográficas, sociais etc. Com o advento tecnológico das traduções simultâneas, os textos passam a ser acessíveis nos diferentes idiomas falados no mundo.

\footnotetext{
${ }^{55}$ SAVAZONI, R.; COHN, S. Cultura digital.br. São Paulo: Azougue Editorial, 2009.p.9-12
} 
O primeiro sistema completo de escrita foi desenvolvido pelos sumerianos no sul da Mesopotâmia cerca de 3000 anos antes de Cristo ${ }^{56}$; outro sistema foi desenvolvido tempos depois pelos antigos egípcios no Delta do Nilo. Folhas de papiro foram originalmente desenvolvidas no Egito por volta do ano 2600 a. C. Eram feitas de uma planta (cyperus papyrus) que crescia no Delta do Nilo e que foi transformada em material para escrita após ser amassada com malho de madeira e posta a secar. Por ser muito mais leve do que a pedra ou a argila, podia ser transportada com facilidade e também permitia ao escriba escrever com mais agilidade e facilidade.

Em 1276, a primeira fábrica de papel surgiu na Itália e em pouco tempo havia pelo menos 12 fábricas na cidade de Fabriano. No século XIV, a Itália se tornou a principal produtora de papel em toda a Europa. ${ }^{57}$

Do mesmo modo as técnicas de impressão foram desenvolvidas na China, técnicas avançadas foram desenvolvidas para imprimir textos religiosos, métodos aperfeiçoados durante a dinastia Sung (960-1280). Na Europa, Gutemberg (1398, 1468, desenvolveu um método para duplicar letras de metal, de tal modo que quantidades de tipos poderiam ser produzidos para composição de textos extensos. Ele também adaptou a prensa, conhecida na Europa desde o século I d.C., com a finalidade de confeccionar textos impressos. Durante a metade do século XV a imprensa se espalhou para os centros comerciais da Europa.

Uma das maiores entre as primeiras imprensas foi a de Anton Koberger ${ }^{58}$, na cidade de Nuremberg em 1470. Entre 1473 e 1513, ele imprimiu pelo menos 236 livros, a maioria deles nas áreas de teologia e filosofia escolástica. A fim de comercializar seus livros, ele estabeleceu uma rede ampliada de vendas com agentes localizados nas importantes cidades da Europa.

Os primeiros passos na difusão em larga escala através do rádio foram dados nos Estados Unidos por volta de 1920. A primeira estação de rádio comercialmente licenciada foi a KDKA, criada por Westinghouse em novembro de 1920. Outros negócios da comunicação como General Electric, ATT e RCA entraram no mercado e mais de 570 estações de rádio foram licenciadas até 1922.

\footnotetext{
${ }^{56}$ MAISELS, C. K. Early Civilizations of the Old World, The formative histories of Egypt, the levant, Mesopotamia, India and China. EUA, Routledge, 2001. p,4

${ }^{57}$ THOMPSON, J. A mídia e a modernidade. Uma teoria social da mídia. Petrópolis: Vozes, 1998.p.57

${ }^{58}$ COMSTOCK, L. K. Anton Koberger e sua marca, Editora Louis K. Comstock, 1930. p,1
} 
As primeiras estações organizadas obtinham lucro de uma variedade de fontes; venda de aparelhos, depois venda de espaço na programação, também através de sublocações de programas para outras organizações.

Os sistemas de difusão foram revolucionados nas décadas de 1940 e 1950, com a chegada da televisão (também no Brasil) ${ }^{59}$. Essa experiência começou tanto na Inglaterra como nos Estados Unidos. A exploração plena dessa ferramenta de comunicação começou depois da Segunda Guerra Mundial. Na Inglaterra, a responsabilidade pela difusão televisiva ficou para a BBC que iniciou no ano de 1946. As primeiras audiências televisivas foram pequenas, mas o grau de crescimento foi rápido, subindo de 1500 permissões em 1947 para mais de 340.000 em 1950, um crescimento de mais de 20 vezes em apenas três anos. ${ }^{60}$

$\mathrm{O}$ rápido crescimento da televisão trouxe consequências para outras indústrias de mídia, pois algumas perderam seu lucro devido à baixa venda de seus produtos. A indústria do cinema também sofreu, as vendas de ingressos para o cinema começaram a cair após a Segunda Guerra Mundial, quando a televisão foi se tornando um meio de comunicação amplamente divulgado. Esse declínio foi se acentuando no decorrer dos anos, e a indústria da televisão proporcionou novos estímulos para a produção de filmes e novos canais de difusão.

Outro aspecto para o crescimento da televisão foi a venda de publicidade. Os jornais obtinham a maior porção das vendas de publicidade, agora a televisão já estava conseguindo captar uma porcentagem significativa dos recursos do mercado para a publicidade.

Com o passar dos anos, o desenvolvimento das redes de televisão na Europa e nos Estados Unidos foram particularmente influenciando outros continentes e o continente Latino Americano foi o que mais sofreu influência econômica e política dos Estados Unidos. A maior parte das instalações e técnicos para os avanços das redes foram fornecidos pelos Estados Unidos por volta dos anos de 1960.

\footnotetext{
${ }^{59}$ CRUZ, R. TV digital no Brasil, tecnologia versus política. São Paulo: SENAC, 2008.

${ }^{60}$ SACKS, Some Technical Considerations of Dirty Joke. In: SCHENKEIN, J. (ed.). Studies in the Organization of Conversational Interaction. New York, NY: Academic Press, 1978. p. 249269. p. 249.
} 


\subsubsection{O poder da mídia numa sociedade de consumo}

Apesar de as instituições de difusão terem se desenvolvido de forma rápida nos países da África, da Ásia e da América Latina, a difusão do equipamento de recepção caminhou lentamente. A amplitude de aparelhos de rádio e televisão nesses países era muito menor do que nas sociedades industriais da Europa. Em 1975 havia 68 rádios e 6 televisores por 1000 habitantes na Ásia, esses números podem ser comparados a 1813 rádios e 530 televisores nos Estados Unidos por 1000 habitantes e 700 rádios e 530 televisores por 1000 habitantes na Inglaterra em $1975 .^{61}$

A indústria da mídia está passando por mudanças que estão causando impacto nos seus produtos e nos modos de produção e difusão ${ }^{62}$. A produção da mídia nas sociedades ocidentais é organizada de forma comercial e opera num mercado competitivo e sujeito a pressões financeiras e a incentivos de governos. Dessa forma, essa indústria se torna dependente dos diferentes programas desenvolvidos por esses grupos de interesse, também é afetada pelo alto preço das novas tecnologias de comunicação.

Os computadores criaram novas possibilidades de transmissão, armazenamento e acesso a informação. Esse desenvolvimento está integrando a indústria da mídia aos diferentes interesses de uma sociedade.

A concentração e diversificação da mídia levaram à formação de conglomerados de comunicação que possuem interesses numa variedade de setores ligados a informação e comunicação. Entre as maiores estão a Time Warner, formada pela junção de Time, Inc. e Warner Communications, em 1989. Esse grupo é o maior publicador de revistas nos Estados Unidos, a segunda maior companhia de TV a cabo no mundo, uma das maiores publicadoras de livros e a maior companhia de vídeos do mundo. Possui subsidiarias na Austrália, na Ásia, na Europa e na América Latina e seu ativo é maior do que o produto nacional da Bolívia, Jordânia, Nicarágua, Albânia, Libéria e Mali, juntos.

As atividades dos conglomerados de comunicação $^{63}$ geralmente são

\footnotetext{
${ }^{61}$ TRIPP, H. Children and Television; Liebes e Katz, Patterns of Infolvement in Television Fiction. EUA, Pensylvania, Penn Libraries,1986,p,6

${ }^{62}$ CARVALHO, A.; MARTINS, S.; VELOZO, V. O poder da mídia. São Paulo: Lê, 1997.

${ }^{63}$ VICENTE, M. M. História e comunicação na nova ordem internacional. São Paulo: Cultura Acadêmica, 2009.
} 
colocadas em evidência devido à atenção concedida a seus proprietários e sócios, às vezes excêntricos que procuram estar sempre em evidência. Esses sócios, proprietários têm sede de poder, querem influenciar todos os segmentos da sociedade, seja na política, no judiciário, nas finanças mundiais e também nos ambientes religiosos. De certa forma eles pretendem que o mundo siga suas orientações e que as coisas se encaminhem de acordo com seus pensamentos megalomaníacos.

Uma característica das indústrias da mídia moderna é a crescente globalização de suas atividades. Neste mundo sem fronteiras, um grupo internacional com sede na Europa exerce influência na África, outro grupo poderoso nos Estados Unidos tem plenos poderes de influência na América Latina.

Surge então em um sistema global de informações e influência. As indústrias da mídia são parte de conglomerados de informações que fazem acontecer um processo de transnacionalização. No ano de 1987, o gigante da eletrônica japonês Sony comprou a marca de discos CBS dos Estados Unidos. Atualmente, a produção internacional de gravações é controlada por cinco grandes marcas: Sony, CBS, RCA, Warner, Thorn-EMI e Polygram, e cada uma delas é controlada e de propriedade de uma corporação internacional.

Um segundo aspecto dessa indústria midiática ${ }^{64}$ refere-se ao crescente papel das exportações e da produção de bens de comunicação para o mercado internacional. As vendas para os países pobres, a influência filosófica dos países ricos, o trabalho nas fábricas, a geração de renda, a venda de séries televisivas etc. Tudo isso gera serviço, transporte, produção em massa e, acima de tudo, influência. São poucos que pensam para muitos. O conceito de globalização é desenvolvido para que o interesse de poucos prevaleça sobre muitos.

Outro aspecto da globalização provém do desenvolvimento das tecnologias que facilitam a difusão e a comunicação transnacional. Materiais impressos e produtos variados, são transportados para os diversos países do mundo. As tecnologias dos satélites dominam e transmitem informações para o mundo todo.

Desse modo, vive-se em um mundo sem fronteiras. Nada impede o avanço da comunicação. Com um sistema de satélites que influencia a sociedade, basta

\footnotetext{
${ }^{64}$ PEDROSO,D.COUTINHO, L.; SANTI, V. J. Comunicação Midiática, matizes, representações e reconfigurações. Rio Grande do Sul: Edipucrs, 2011.
} 
enviar uma comunicação seja qual for o seu teor e o cidadão terá acesso a ela e receberá o impacto da influência em suas escolhas.

Esse fenômeno também acontece no ambiente da religião, que sofre tanto pelos aspectos positivos quanto negativos decorrentes da comunicação. O ideal deve ser usar essas ferramentas para que os valores e princípios cristãos sejam propagados por todo o mundo.

Em poucos setores o poder se consolidou de forma tão impactante quanto o setor da informação e das comunicações. O rápido desenvolvimento das tecnologias levaram a coexistir na mesma plataforma diferentes tipos de conteúdo (notícia, análise, opinião, anúncio, propaganda, influência) a partir de diversos segmentos.

Os meios de comunicação que antes estavam separados, agora estão convergindo. Os jornais impressos produzem imagens para suas páginas na internet, os canais de televisão produzem imagens que serão apresentadas via sites que são extensão do canal de TV. As igrejas, que antes exerciam influenciam em seus redutos e paróquias próprias, agora produzem apresentações para televisão e internet no mesmo nível de outros meios de comunicação. Celulares e tablets tornaram-se veículos para informar, entreter, comunicar e influenciar. ${ }^{65}$

Os cidadãos da sociedade moderna têm visto seus jornais se transformarem em uma apresentação visual e interativa, cada indivíduo tem a oportunidade de participar e opinar a respeito dos temas em questão. Os espectadores agora encontram sua opção de informação, seja religiosa, para compras e negócios, on demand e pela internet.

Os ouvintes de rádio e TV podem acessar via internet sua estação favorita e escolher o tipo de programa que querem ouvir, o atual ou o que já foi transmitido dias atrás. O Google ${ }^{\circledR}$ fornece todo tipo de informação, atual, passada ou até mesmo do futuro. Além disso, tem a influência de amigos que, via Twitter ou Facebook, sugestionam para o que se deve ler, ouvir e ler. ${ }^{66}$

As repercussões sobre essa transformação radical e tecnológica na sociedade ainda não são compreensíveis com exatidão. Surgem então diversos questionamentos: onde está o poder na mídia, em que direção está caminhando, como irá se consolidar o poder através dos recursos tecnológicos que o cidadão

\footnotetext{
${ }^{65}$ HERNANDES, N. A mídia e seus truques. São Paulo: Contexto, 2010.

${ }^{66}$ BAGDIKIAN, B. H. O monopólio da mídia. São Paulo: Scntta, 1993.
} 
tem disponível, como as igrejas ou as instituições religiosas reagirão a todo esse desenvolvimento ${ }^{67}$.

É evidente que um pequeno número de grandes empresas, igrejas e instituições controlam uma parcela grande da mídia global. Outro fator a ser considerado são as redes sociais, como o Facebook. Essa ferramenta responde por um em cada cinco anúncios digitais vendidos. As relações que existem entre as empresas gigantes e as grandes igrejas são implacáveis e competitivas. Mesmo em alguns casos onde trabalham com cooperação, seus executivos às vezes ocupam cargos entre as organizações com os mesmos objetivos.

A experiência de consumo e divulgação via internet expandiu o leque de opções. Essa indústria de mídia tem como marca principal a volatilidade, isso se aplica para as ações das igrejas, sendo assim as igrejas que desenvolvem estratégias conservadoras de ação, terão um alcance limitado para suas ações ${ }^{68}$.

A mídia, com sua capacidade de apelar para a curiosidade e o sistema de crenças, faz com que seu poder resida tanto na autoridade (de quem se escreve e suas fontes) e na influência (sobre o ponto de vista e as decisões). Ao modo de ver das pessoas, existe uma igreja de referência, um comunicador de referência, uma revista de referência, um ponto de vista emitido de alguma fonte midiática que servirá como ponto de partida para algum posicionamento de valor. Um novo questionamento surge: Qual igreja ou qual instituição religiosa é digna de credibilidade?

Uma sutil hierarquia posiciona certos veículos de mídia a frente dos outros quanto à credibilidade e ao prestígio. Poucos aspectos ou funções são atualmente exclusivos de um tipo de organização midiática. Notícias, opinião, entretenimento são ações legítimas, veículos impressos de áudio e vídeo estão cada vez mais interagindo. A facilidade de acesso acaba incentivando o cidadão a participar com curiosidade e desejo de aprendizado. O setor está ficando cada vez mais comercial e com mais entretenimento, levando as instituições religiosas para o mesmo caminho.

O acesso digital já faz parte das grandes igrejas, as ações de comunicação passam pela mídia impressa, falada e escrita, usando as mesmas regras das redes sociais. Sendo a movimentação midiática um setor que experimenta um estado tão

\footnotetext{
${ }^{67}$ BUCCI, E. Brasil em tempo de TV. São Paulo: Boitempo, 1996.

${ }^{68}$ CASTELLS, Manuel. A sociedade em rede. São Paulo: Paz e Terra, 1999.
} 
intenso de movimentação contínua e de revolução tecnológica, é inevitável a ascensão e a importância cada vez maior de todo tipo de participante. Assim, alcança-se um número cada vez maior de pessoas e os que emitem opinião vão se resumindo a um pequeno número.

A crescente popularização dos aparelhos tecnológicos (tablets, celulares, microcomputadores), criou um aumento do consumo de notícias, mas também uma corrida em busca de qualidade da notícia e de novidades. Se há um setor onde a transformação do poder está acontecendo diariamente em todas as partes é o dos meios de comunicação.

Igrejas, sindicatos, organizações filantrópicas e midiáticas estão existindo a partir de uma nova configuração. Uma mudança de poder está acontecendo entre as organizações, incluindo entre elas as igrejas. Existe hoje uma crescente competição global entre as organizações cristãs para atrair profissionais competentes em suas respectivas áreas de atuação, para atuarem de tal maneira que ajudem a expandir a marca e a ação dessas igrejas.

As grandes igrejas se tornaram um empreendimento mais global do que nacional, com colaboradores distribuídos em diversos países; novas regras de intercâmbio de dados e de conhecimentos são desenvolvidas a cada dia. Vive-se a revolução "do mais", pois esta é uma sociedade insatisfeita, sempre querendo mais, desejando possuir mais, aprender mais, ter mais poder ${ }^{69}$.

Também pode se destacar a revolução da mobilidade, o ser humano tem alcançado um estágio de mobilidade jamais visto na sua história. Vive-se em um mundo sem fronteiras, as distâncias são vencidas com maior velocidade. Em poucas horas uma pessoa que está hoje em São Paulo chega a Paris. Com essa mesma rapidez, as informações são trocadas pelos cidadãos do planeta. No mundo globalizado, um cidadão do Nepal conversa com um canadense e troca imagens com alguém que vive na África do Sul. O mesmo ocorre com os sistemas de poder, hoje funcionam de uma forma, amanhã serão apresentados de maneira totalmente diferentes.

Além disso, há a revolução da mentalidade. O ensino e o aprendizado são virtuais, ninguém detém o segredo do conhecimento, todos têm acesso ao saber, as crianças de hoje têm uma gama maior de informação do que os gênios do

\footnotetext{
${ }^{69}$ JAMESON, Fredric. A cultura do dinheiro: ensaios sobre a globalização. Petrópolis: Vozes, 2001.
} 
passado. Vive-se com cidadãos que têm uma mentalidade de vanguarda e moderna, portanto os conceitos devem ser bem fundamentados, o saber está no ar, todos podem saber de tudo o que é possível a qualquer momento.

Essa dinâmica existencial, essa realidade de vida aplica-se ao poder e, por sua vez, chega às instituições religiosas. As igrejas vivem debaixo de uma nova realidade de poder no mundo contemporâneo. O poder tem sido mais fácil de obter, mais complicado para usar e mais difícil de sustentar.

Na religião, na mídia e na filantropia, as disputas são intensas, vive-se em tempos de guerras religiosas, disputas sem fim com o objetivo de alcançar almas, corações, e cérebros. Há não só a intervenção de novas forças, mas também a polarização que estão transformando as sociedades em vários níveis. Há mais opção do que nunca, mas, ao mesmo tempo, o domínio e o poder estão nas mãos de poucos. Com diz Ribeiro parafraseando Foucault: Numa sociedade é fácil identificar aqueles que não tem poder, o difícil é saber quem são os poderosos. ${ }^{70}$

A partir dessas considerações; o que acontece com a fé, quando se estilhaça em um milhão de pedaços? Quando a busca do bem comum descamba para projetos desenhados para promover determinadas causas preferidas por pessoas que têm o dinheiro para financiá-las? Quando os cidadãos ignoram as notícias que afetam a todos para se interessarem por aquelas que lhe são convincentes. Será que as novas opções de poder favorecem ao ser humano ou tudo se transforma em ações de poucos usufruindo as vantagens sobre muitos.

\subsubsection{A desregulamentação midiática}

Os governos procuram regulamentar as atividades das organizações midiáticas. Por sua vez, os grandes grupos lutam contra qualquer tipo de regulamentação. Na Inglaterra e em vários países europeus, a difusão, o rádio e a televisão eram estritamente regulados pelo estado, que concedia permissões às instituições de difusão, distribuía o alcance das ondas e controlava o conteúdo das transmissões.

\footnotetext{
${ }^{70}$ PLONER, K. S., et al., (org). Ética e paradigmas na psicologia social. Rio de Janeiro: Centro Edelstein de Pesquisas Sociais, 2008. p,313
} 
A regulamentação da difusão ${ }^{71}$ era justificada com o argumento de que, dentro de qualquer espaço territorial específico, existia um número limitado de canais a disposição para transmissão de sinais de rádio e televisão. Esta justificativa era acrescida do argumento de que a difusão era essencialmente um serviço público. Para muitos dos primeiros comunicadores e legisladores ingleses e europeus, essa tese era reforçada por uma aversão ao comercialismo e por um medo sobre as possíveis consequências danosas de uma difusão descontrolada. Eles tinham consciência sobre o poder e a influência dos meios de comunicação sobre a sociedade.

A desregulamentação dos veículos de comunicação deu-lhes a liberdade para agirem de acordo com seus interesses e políticas organizacionais, a isso se chama liberdade de impressa. O processo de desregulamentação foi impulsionado pelo desenvolvimento de novas tecnologias na esfera das telecomunicações.

Com o progresso nos sistemas de transmissão por cabo e por satélite, os argumentos tradicionais de controle vieram por terra. As grandes redes precisam vender seus produtos, o comércio prevaleceu, as organizações se profissionalizaram de forma comercial; como cada segundo vale ouro, eles vão aumentando seu papel de dominação na nova economia global da informação e comunicação.

O mesmo também aconteceu no Brasil. A velocidade da informação é um dos maiores reflexos dos benefícios advindos do avanço da tecnologia para a sociedade atual. A presença da televisão nos domicílios dos cidadãos brasileiros chega a quase ser unânime.

A proporção de domicílios brasileiros com acesso à internet, considerando também conexões por telefone celular, ficou praticamente estabilizada em 51\%. Em 2014, a fração era de $50 \%$ e em 2013, de 43\%. De acordo com o levantamento, 34,1 milhões de domicílios no Brasil têm acesso à internet, sendo que as classes mais abastadas têm mais acesso: $97 \%$ dos domicílios da classe A têm internet, seguidos por $82 \%$ da classe $\mathrm{B}, 49 \%$ da classe $\mathrm{C}$ e16\% da D/E.Em relação à região, o Sudeste tem o maior número de domicílios conectados à internet, quanto desconectados: são 17,4 milhões de domicílios conectados e 11,7 milhões, desconectados. A Região Nordeste tem 7 milhões de domicílios com internet e 10,5 milhões sem internet; a Região Sul tem 5,4 milhões conectados e 4,9 milhões desconectados; o Centro-Oeste tem 2,5 milhões com internet e 2,7 milhões sem. A Norte tem 1,9 milhões de domicílios conectados e 3,1 milhões, desconectados.O levantamento mostra que a proporção de domicílios brasileiros com computador estabilizou em

\footnotetext{
${ }^{71}$ RIBEIRO, A. P. G.; FERREIRA, L. M. A. Mídia e Memória: a produção de sentidos nos meios de comunicação. Rio de Janeiro: Mauad Editora, 2007.
} 
50\% - mesma proporção registrada em 2014 - o que representa 33,2 milhões de domicílios com acesso a computador. Segundo a pesquisa, $99 \%$ da classe A têm computador em casa, seguido de $84 \%$ da classe B, $47 \%$ da classe C e $13 \%$ da $\mathrm{D} / \mathrm{E}^{72}$

A sociedade moderna tem intensificado a cultura do culto ao corpo, e os sujeitos intensificam uma preocupação desproporcional à imagem e à estética. Todas as classes sociais e as diferentes faixas etárias são afetadas. Segundo Bourdieu, sociólogo francês, a linguagem corporal é marcada pela posição social, que coloca o modo de alimentação, as questões culturais e a forma de apresentação através do vestuário, da higiene e do cuidado com a beleza como os mais importantes modos de distinguir um indivíduo de destaque na sociedade.

Nas sociedades modernas há uma crescente preocupação com o corpo $^{73}$, com a dieta alimentar e o consumo excessivo de cosméticos, impulsionados basicamente pelo processo de massificação das mídias a partir dos anos 1980, quando o corpo ganhou mais espaço, principalmente nos meios midiáticos. Não por acaso foi nesse período que surgiram as duas maiores revistas brasileiras voltados para o tema: "Boa Forma" (1984) e "Corpo a Corpo" (1987).

A maior influência, no entanto, vem do cinema de Hollywood que tem ajudado a criar novos padrões de aparência e beleza. Esses conglomerados da comunicação ajudam a difundir novos valores de cultura e consumo projetando para o indivíduo, seja rico ou pobre, um padrão glamoroso de vida, exercendo até mesmo certa pressão social para que todos se comportem dessa forma, seja no modo de vestir, na aparência e na sua projeção social.

Com relação à televisão é possível tirar algumas conclusões, pois veicula imagens de corpos e de vidas de pessoas perfeitas em sua grade de programação e peças publicitárias, novelas, filmes etc. Surge para o sujeito telespectador a imagem da "eterna juventude" associada a um corpo perfeito, independente da faixa etária e da classe social. Cinema, televisão, publicidade, revistas etc. são ferramentas e instrumentos de valores e influência para a sociedade, que, por sua vez, não isenta a sociedade religiosa, que responde às vezes na integra a essa proposta de valores.

\footnotetext{
${ }^{72}$ http://agenciabrasil.ebc.com.br/pesquisa-e-inovacao/noticia/2016-09/pesquisa-mostra-que-58da-populacao-brasileira-usam-internet 18112017

${ }^{73}$ FREITAS, B. P. A Beleza Hiper Real. Clube dos Autores, 2008. p,161
} 
O consumismo exagerado incentivado pela mídia ${ }^{74}$ em geral pretende alcançar as categorias mais jovens, para que se transformem em consumidores, apresentando modelos de roupas, estereótipos de pessoas iguais aos artistas apresentados pelas imagens. Assim, essas pessoas da sociedade promovem o crescimento da indústria cosmética e farmacêutica, com seus produtos para inibir o apetite, a indústria de roupas, com seus modelos novos que são lançados a cada dia. A Sociedade Brasileira de Cirurgia Plástica apresenta uma estimativa de que cerca de 130 mil crianças e adolescentes submeteram-se no ano de 2009 a operações plásticas.

A premissa básica da teoria do agendamento na sua forma moderna foi formulada originalmente por Bernard Cohen, em 1963: Na maior parte do tempo, a mídia e a comunicação pode não ter êxito em dizer aos leitores "como" pensar, mas é espantosamente exitosa em dizer aos leitores "sobre" o que pensar.

Essa teoria no original em inglês é uma teoria de comunicação, formulada por Maxwell McCombs e Donald Shaw, na década de 1970. De acordo com essa tese, a mídia determina a pauta para que a edição destaque determinados temas ou ofusque outros de seu interesse. A ideia básica vem de Walter Lippmann, um jornalista dos Estados Unidos, que em 1922, propôs a tese de que as pessoas não respondiam diretamente aos fatos do mundo real, mas que vivem num pseudoambiente, seguindo o pensamento principal de Bernard Cohen. ${ }^{75}$

Ao desenvolverem estudos sobre como os veículos de comunicação cobriam campanhas políticas eleitorais, Shaw e McCombs constataram que o principal efeito da impressa é pautar os assuntos relacionados à esfera pública, dizendo às pessoas não o que pensar, mas em quem pensar. Eles se referem ao agendamento como uma função da mídia e não como uma teoria.

A teoria do agendamento ocorre porque a imprensa tem uma função seletiva ao noticiar os fatos. Os profissionais de notícia atuam como "porteiros" da informação, deixando passar algumas e barrando outras, na medida em que escolhem noticiar ou ignorar. O que o público sabe e como se importa em dado momento é um produto da mídia e dos veículos de comunicação. A mensagem é trabalhada respondendo aos interesses diversos.

\footnotetext{
${ }^{75}$ FERREIRA, A. J.; STOBAUS, C. D.; GOULART, D; MOSQUERA, J. J. M. Educação e Envelhecimento. Rio Grande do Sul: Edipucrs, 2012. p. 23.

75 COHEN, I. Bernard, WESTFALL, Richard S.(orgs.). Newton: textos, antecedentes, comentários. Rio de Janeiro: Contraponto. p. 524.
} 
A teoria do agendamento se divide de algumas formas: 1) Agenda midiática, questões discutidas na mídia; 2) Agenda pública ou da sociedade civil, questões discutidas por pessoas relevantes para o público; 3) Agenda de políticas públicas, questões que os gestores públicos consideram importantes. A questão que se debate é o nível de influência de uma agenda entre a outra. Um assunto que é veiculado, mesmo não sendo de grande repercussão, acaba colocando em esquecimento outros assuntos, ainda que estes sejam de grande importância para a sociedade.

O termo "agenda" significa pauta de fixação, uma forma de direcionar a atenção dos leitores e telespectadores de uma reportagem ou notícia, ou seja, em outras palavras, a mídia aponta quais temas serão considerados de interesse coletivo. Segundo Wallter Lippmann ${ }^{76}$, o conhecimento que as pessoas têm do mundo exterior é formado pela seleção midiática de símbolos presentes no mundo real, criando uma relação entre a agenda midiática e a agenda pública.

A "agenda" segue certos fatores condicionados à mensagem e à recepção, levando em conta a necessidade de orientação para o público sobre determinados assuntos. A respeito da mensagem, a análise mais importante está nas chamadas políticas, pois a mídia interfere na formação da opinião pública a respeito da luta pelo poder. Nesse caso, são usadas a dramatização dos acontecimentos noticiados, a personalização do conteúdo das matérias e a apropriação da dinâmica dos acontecimentos para acelerar a compreensão da mensagem. Para se entender: a mídia deseja que a mensagem tenha o entendimento que se pretende ao interesse da notícia.

$\mathrm{Na}$ televisão, a "agenda" é utilizada em notícias de interesse geral com forma de influenciar a agenda pública, por meio de uma cobertura intensa, num curto espaço de tempo. Surge outra teoria: a espiral do silêncio, que foi criada por Noelle-Neuman em $1972 .^{77}$

Essa teoria inicia quando acontece o medo do isolamento social da parte dos indivíduos, fazendo-os sentirem-se isolados caso discordem da opinião pública que está dominando e se impondo na sociedade pelos veículos de comunicação. O silêncio das opiniões minoritárias, ou colocadas como minoritárias, tende a se

\footnotetext{
${ }^{76}$ LIPPMANN, Walter. Public Opinion. Nova York: MacMillan, 1922.

${ }^{77}$ NEUMAN, Elisabeth, La Espiral del Silencio. Opinión Publica: nuestra peil social. Barcelona: Paidós, 1995.
} 
tornar cada vez mais isolador na medida em que a opinião geral toma mais força através da mídia.

$\mathrm{Na}$ teoria do agendamento se desenvolve a tese do jornalismo como distribuidor de saberes ${ }^{78}$ : Em decorrência da ação dos jornais e da televisão e dos outros meios de informação, o público sabe ou ignora, presta atenção ou descobre, realça ou negligencia elementos específicos dos cenários públicos.

As pessoas têm a tendência para incluir ou excluir dos seus conhecimentos aquilo que a mídia inclui ou exclui do seu conteúdo. Além disso, o público tende a absorver aquilo que esse conteúdo inclui como importante ou que reflita a ênfase atribuída pelos meios de comunicação aos problemas enfrentados pelas pessoas.

Outro destaque na teoria do agendamento descrito por Walter Lippmam constituiu uma das mais respeitadas obras de estudo da cultura de massa e opinião pública da época, com repercussão até nossos dias. Para ele, a notícia não é um espelho das condições sociais, mas o relato de um aspecto que se impôs na sociedade. Com o passar do tempo e com o ponto de vista de outros teóricos, a teoria do agendamento pressupõe que as notícias são como são porque os veículos de comunicação nos dizem o que pensar, e como pensar a respeito dos fatos noticiados.

A teoria do agendamento defende a ideia de que os consumidores de notícias tendem a considerar como fatos mais importantes os veiculados pela impressa, sugerindo que os meios de comunicação agendam nossas conversas. ${ }^{79} \mathrm{~A}$ influência da mídia nas conversas dos cidadãos é resultado da dinâmica organizacional das empresas de comunicação, que comunicam sua cultura própria, critérios de notícias, próprio e filosofia e ideologias do grupo que está noticiando o fato. No Rio de Janeiro, por exemplo, o assunto a respeito da violência tem espaço diário nos jornais. A ação da mídia no conjunto de conhecimentos sobre a realidade social forma a cultura e atua sobre ela.

Para Noelle Neumam, essa ação tem três características básicas. 1) Acumulação: é a capacidade da mídia para criar e manter relevância de um tema; 2) Consonância: as semelhanças nos processos produtivos de informação tendem a ser mais massivos e significativos do que as diferenças; 3) Onipresença: o fato

\footnotetext{
${ }^{78}$ DE FLEUR, Melvin L. Teorias de Comunicação de Massa. Rio de Janeiro: Zahar, 1971.

${ }^{79}$ TARDE, Gabriel. A Opinião e as Massas, São Paulo: Martins Fontes, 1992.
} 
de a mídia estar em todos os lugares com o consentimento público, que cede para sua influência.

Desse modo, a teoria do agendamento diz que as notícias pautam o dia a dia, as conversas e tudo isso acontece pelo poder da mídia de selecionar o mais importante e fazer com que o público conclua que aquilo é o mais importante no seu ponto de vista. Às vezes o poder de convencimento da mídia parece manipulação, a mídia deve expor as notícias que julga importante e o público tradicionalmente deve analisar o seu conteúdo a partir do seu sistema de valores. ${ }^{80}$

A mídia se torna poderosa porque é detentora da notícia, com esse conhecimento ela chega até o cidadão levando-o a pensar de acordo com seus interesses. Cabe a teologia apontar os caminhos da verdade, não se deixar manipular nem distorcer os fatos, apresentando para o cidadão a realidade dos valores do reino de Deus.

Se a igreja se omitir, o cidadão fica à deriva, não tem em quem confiar, sem ter onde buscar uma palavra de orientação e esperança para sua vida aqui e agora, e também a respeito da vida eterna. A agenda da igreja deve ser pautada pela Bíblia Sagrada, os temas éticos, religiosos, filosóficos da sociedade devem ser pautados a partir da palavra de Deus, essa é a tarefa principal da igreja, anunciar para todos que é chegado o reino de Deus.

\subsubsection{A degradação do poder}

O fato é que o "poder" está passando por uma transformação histórica, pois a forma convencional do exercício do poder está convivendo com novos e surpreendentes modelos.

O poder está se transferiu daqueles que têm a força bruta para aqueles que têm o conhecimento e a tecnologia; está sofrendo uma mutação. Enquanto estados, empresas, partidos políticos, movimentos sociais e instituições ou lideranças lutam pelo poder, agindo conforme a norma, o poder que eles conhecem e praticam está perdendo a eficácia.

O poder já não é mais o que era. No século XXI, o poder é mais fácil de

${ }^{80}$ BARROS FILHO, Clóvis. Ética na Comunicação: da informação ao receptor. São Paulo: Moderna, 1995. 
obter, mais difícil de utilizar e mais fácil de perder. Por isso é preciso entender de que modo o poder está perdendo seu valor, e enfrentar os desafios é a chave para identificar uma das mais importantes tendências de reformulação do século XXI. Em tese: A nova configuração do poder está mudando o mundo. ${ }^{81}$

O mundo em perspectiva: 1) Há mais pessoas morando em cidades do que no campo; 2) A queda das barreiras está transformando a política local e a geopolítica; 3) A competição entre as empresas para conquistar os consumidores; 4) A disputa entre as grandes religiões para conquistar adeptos; 5) A rivalidade entre as organizações não governamentais. Onde quer que o poder tenha relevância, está em declínio e perdendo a potência.

\begin{abstract}
Um exército grande e moderno não garante mais por si só que um país irá alcançar suas metas estratégicas. O lado mais fraco tem cada vez maior capacidade de causar baixas ao seu oponente por um custo menor. Ditadores e chefes de partidos estão vendo seu poder enfraquecer e seu número diminuir. Em 1977, havia 89 países governados por ditadores, por volta de 2011, esse número reduziu para 22 , atualmente mais da metade da população mundial vive em democracias ${ }^{82}$
\end{abstract}

Além disso, a renda e a riqueza pessoal não são as únicas fontes de poder. Os líderes das grandes corporações acabam exercendo mais poder do que os que são "apenas" ricos. As fusões no mundo dos negócios adentram a filantropia, a religião, a cultura e o poder pessoal e individual. O número de novos bilionários tem alcançados recordes significativos, a cada ano vários nomes desaparecem da lista enquanto indivíduos dos quatro cantos do mundo assumem seu lugar.

A filantropia deixou de ser o domínio exclusivo das grandes corporações e organizações públicas, surgiram as pequenas fundações e novas modalidades de doação em que o doador entra em contato direto com o beneficiário, tomando um atalho ao modelo clássico das instituições beneficentes. A filantropia como investimento acabou dando margem a um novo setor econômico criado para apoiar e organizar esse dinheiro distribuído no mundo, para doações.

Doutra feita o grande poder das religiões organizadas está em declínio. As igrejas pentecostais demonstram crescimento em países que já foram fortalezas do Vaticano. No Brasil, os pentecostais e os carismáticos constituíam apenas 5\% da população em 1960, em 2016 já perfazem em torno de 35\% da população, e esse

\footnotetext{
${ }^{81}$ MOISES, N. O Fim do Poder. São Paulo: Texto Editores, 2013. p. 21.

${ }^{82}$ MOISES, N. O Fim do Poder. São Paulo: Texto Editores, 2013. p. 21.
} 
número também é crescente em outros países (11\% na Coreia do Sul, $23 \%$ Estados Unidos, 26\% Nigéria, 30\% Chile, 34\% África do Sul, 44\% Filipinas, 56\% Quênia, 60\% Guatemala). As igrejas pentecostais geralmente são pequenas e se adaptam à realidade dos fiéis, algumas chegam a ser megaigrejas e cruzam fronteiras, como a brasileira Universal do Reino de Deus, com 4 milhões de membros. $^{83}$

E o Islã, que não é centralizado, e mesmo assim continua a se dividir à medida que estudiosos Imãs oferecem interpretações conflitantes a respeito das doutrinas fundamentais do alcorão e usam poderosas plataformas de televisão e internet.

Para concluir: O poder está se tornando mais frágil e vulnerável. Vive-se em tempos em que o poder se tornou mais concentrado e que aqueles que o detêm são mais fortes. Muitos pensam que o poder é igual ao dinheiro que tem na conta, quem tem mais dinheiro, tem mais poder; a partir desse ponto de vista, o ciclo de concentração de poder e das riquezas se tornou a mola mestra de funcionamento da história humana. Agora não se pode negar que a transformação do poder é uma realidade. O próprio poder se tornou mais disponível; no mundo atual, mais pessoas tem mais poder.

Segundo Aristóteles: ${ }^{84} \mathrm{O}$ poder, a riqueza, e as amizades, são os três componentes básicos que constituem a felicidade de uma pessoa. A ideia de que o ser humano naturalmente busca o poder e os governantes procuram o consolidar e expandir seu domínio é quase consensual na filosofia. Como disse Maquiavel: "A aquisição de território e do controle político, é na verdade muito natural e comum, os homens fazem assim sempre que podem." 85

Thomas Hobbes disse no livro Leviatã: "Considero como inclinação geral de toda humanidade um desejo perpetuo e irrequieto de poder e mais poder, que cessa apenas com a morte." 85

Friedrich Nietzsche: "Onde encontrei a vida, ali encontrei a vontade de poder; até mesmo na vontade do servo encontrei a vontade de ser senhor." 85

\footnotetext{
${ }^{83}$ MOISES, N. O Fim do Poder. São Paulo: Texto Editores, 2013. p. 25.

${ }^{84}$ CABRAL, João Francisco Pereira. "A concepção de felicidade na Ética aristotélica."; Brasil Escola. Disponível em <http://brasilescola.uol.com.br/filosofia/a-concepcao-felicidade-na-Eticaaristotelica.htm>. Acesso em 20 de fevereiro de 2017.

${ }^{85}$ MOISES, N. O Fim do Poder. São Paulo: Texto Editores, 2013. p. 63.
} 


\subsection{O sujeito midiático uma nova imagem do humano ${ }^{86}$}

Já faz um bom tempo que o ser humano vem perdendo a esperança no paraíso eterno, onde se propõe a felicidade eterna. Essa perda de esperança começa no movimento iluminista, que procurava um rompimento com a fé através das evidências da razão.

Na Idade Média, a humanidade tinha encontrado esperança na fé, e essa época, de certa forma, ficou conhecida como a época da Cristandade, era muito difícil para o ser humano ter o domínio de si mesmo sendo a fé um princípio fundamental para a vida humana. Os medievais não descobriram uma abertura que lhes possibilitasse publicamente assumir a posição "Eu sou".

A modernidade se consolidou com o surgimento do Iluminismo (Sec XVIII) que destacou como absoluta a razão. Esse movimento se levantou contra os vínculos cegos e absurdos da tradição, da ignorância, da superstição, do mito e da opressão. Os principais alvos da crítica iluminista foram a igreja e a monarquia, a duas principais instituições da época.

A crítica iluminista foi alimentada pelo Renascimento, que lutava conta tudo o que interferisse na autonomia do ser humano. Surgiu, de modo objetivo, o "princípio da autoridade" e a reforma religiosa do século XVI que dirigia sua luta contra as autoridades do campo religioso.

O iluminismo tinha como base conceitual: "o ser humano racional", ligado à ciência e tendo como sua figura principal o filosofo René Descartes ${ }^{87}$, em vários casos citado como o "pai da filosofia moderna". Descartes apresentou o ser humano pensante, racional e consciente. Seu lema principal era: "Penso, logo existo", que deu a ideia de o sujeito cartesiano. Esse sujeito foi criado a partir do conceito da pessoa humana totalmente centrada, una, dotada de capacidades relacionadas à razão e de consciência e de ação.

Durante esse período controverso, os limites e a coerência nas ações começaram a desconcertar o ser humano proposto por Descartes, o homem cartesiano. Por volta da metade do século XX, foram iniciados os questionamentos sobre esse "indivíduo isolado" e alienado vivendo nas grandes

\footnotetext{
${ }^{86}$ THOMPSON, J. A mídia e a modernidade. Uma teoria social da mídia. Petrópolis: Vozes, 1998.p,28-36

${ }^{87}$ DESCARTES, R. Discurso do Método, Meditações, Objeções e respostas, As paixões da Alma e Cartas. São Paulo: Abril Cultural, 2000.p,86
} 
metrópoles e nos centros urbanos.

Segundo Stuart Hall ${ }^{88}$ cinco avanços da teoria social e nas ciências humanas, vieram para desconstruir o ser humano cartesiano:

1) $O$ primeiro, refere-se às tradições dos pensamentos marxistas, que afirma que os seres humanos fazem a história, mas apenas de acordo com as condições que lhe são dadas. Esse raciocínio teve grande influência sobre os vários ramos dos pensamentos.

2) Outro ponto surge a partir da descoberta do inconsciente com os estudos de Freud, que diz que a identidade, a sexualidade e a estrutura dos desejos são formados com base em processos mentais e simbólicos do inconsciente, que funciona de acordo com uma "lógica" muito diferente daquela proposta pelo iluminismo e acaba com o conceito do sujeito racional proposto por Descartes.

3) O terceiro diz respeito à tese de Ferdinand de Saussure (1916). Ele argumentava que nós não somos, em nenhum fundamento, "autores" das afirmações que fazemos ou dos significados por nós expressos através da fala, pois a linguagem é um sistema social e não individual, ou seja, há uma ação específica entre nós e nossos sistemas culturais.

4) O quarto provém de uma tese desenvolvida pelo filosofo e historiador Michel Foucault analisada por Rabinow e Dreyfus", que denominou de "poder disciplinar" aquele que consiste em manter a vida, o trabalho e os prazeres dos indivíduos sobre o controle do Poder. ${ }^{90}$ Esse poder é o produto das novas instituições coletivas que policiam e disciplinam as populações modernas, tais como: hospitais, prisões, escolas, quartéis, igrejas etc.

5) O quinto é o impacto do feminismo 91 , "um novo movimento social" que surgiu durante a década de sessenta do século $\mathrm{XX}$, juntamente com os movimentos estudantis pela paz. Esses movimentos abriram temas para novos questionamentos a respeito da saúde, da família, da religião etc. O feminismo levantou algo novo, a questão da diferença sexual, em que homens e mulheres fazem parte do mesmo contexto. Outros conceitos como instabilidade e anomalias

${ }^{88}$ HALL, Stuart. A Identidade Cultural na Pós-Modernidade. Rio de Janeiro: DP \& A, 2001.p,22

${ }^{89}$ RABINOW, Paul; DREYFUS, Hubert. Michel Foucault. Uma trajetória filosófica para além do estruturalismo e da hermenêutica. Rio de Janeiro: Forense Universitária, 1995. p. 96.

${ }^{90}$ STUART Hall. A Identidade Cultural na Pós Modernidade. Rio de Janeiro: PA Editora, 2006, p. 42.

${ }^{91}$ TUANA, N. (ed.) Feminism and science. Bloomington: Indiana University Press, 1987. p.34 
diversas, junto com os processos de transnacionalização e globalização, serviram para delimitar os conceitos da modernidade.

\subsubsection{Alguns desafios para o sujeito midiático pós- moderno ${ }^{92}$}

O ser humano pós-moderno foi desconstruindo o sistema de crenças que era base para seu modo de vida. Essas mudanças estruturais e institucionais geradas pela modernidade resultaram no sujeito pós-moderno. As referências culturais, os assuntos relacionados ao gênero, a sexualidade, a etnia, a raça e a nacionalidade, que anteriormente forneciam base para a construção do sujeito, entraram em crise. Essas mudanças estão também mudando os indivíduos a respeito de suas identidades pessoais, religiosas, institucionais, desconstruindo a ideia que se tem de si mesmo e dos outros que vivem em sociedade.

Seguindo a análise dos desafios para o ser humano pós-moderno: O materialismo, a cultura, a produção e o consumo de massa na pós-modernidade fornecem sinais para analisar e entender esse "novo sujeito religioso" que é ao mesmo tempo livre, determinista, ávido pelo prazer, que almeja ser livre de limitações, enquanto transita de uma posição a outra com muita facilidade, porque é assim que ele pensa e age.

$\mathrm{Na}$ pós-modernidade se destaca o predomínio do individual sobre o universal, os diversos autores a descrevem como uma época de intensa diversidade de condutas e interesses, tendo como base o esgotamento do impulso moderno para o futuro com o desaparecimento das crenças e tendo como base os

\footnotetext{
${ }^{92}$ A ideia de "pós-modernismo" surgiu pela primeira vez no mundo hispânico, na década de 1930, uma geração antes de seu aparecimento na Inglaterra ou nos EUA. Perry Anderson, conhecido pelos seus estudos dos fenômenos culturais e políticos contemporâneos, em "As Origens da PósModernidade" (1999), conta que foi um amigo de Unamuno e Ortega, Frederico de Onís, que imprimiu o termo pela primeira vez, embora descrevendo um refluxo conservador dentro do próprio modernismo. Mas coube ao filósofo francês Jean-François Lyotard, com a publicação "A Condição Pós-Moderna" (1979), a expansão do uso do conceito. Em sua origem, pós-modernismo significava a perda da historicidade e o fim da "grande narrativa" - o que no campo estético significou o fim de uma tradição de mudança e ruptura, o apagamento da fronteira entre alta cultura e da cultura de massa e a prática da apropriação e da citação de obras do passado. Diz que o modernismo era tomado por imagens de máquinas [as indústrias] enquanto que o pósmodernismo é usualmente tomado por "máquinas de imagens" da televisão, do computador, da Internet e dos shopping centers. O pós-moderno é muito mais a fadiga crepuscular de uma época que parece extinguir-se ingloriosamente que o hino de júbilo de amanhãs que despontam. À consciência pós-moderna não corresponde uma realidade pós-moderna. Nesse sentido, ela é um simples mal-estar da modernidade, um sonho da modernidade. ANDERSON, Perry. As Origens da pós-modernidade. Rio de Janeiro: Jorge Zahar, 1999.
} 
discursos e a lógica de consumo ${ }^{93}$.

Tendo como base o sujeito moderno, que tem uma identidade unificada e estável, e que foi transformado num indivíduo plural, com várias identidades, narcisista e preocupado com seu bem-estar, inserido numa sociedade que exalta o consumismo materialista como seu maior objetivo de vida, anseia desesperadamente por satisfação pessoal e ainda busca uma peculiar ligação com o divino.

De acordo com Montero ${ }^{94}$, o que ocorre, por um lado, é que a experiência religiosa parece ter sido expulsa dos "recônditos obscuros do eu". Os profundos sentimentos religiosos baseados na fé que consola, reconcilia, abençoa e redime parecem ter perdido a base que lhes davam sustentação.

A religiosidade acontece no âmbito particular do sujeito e é caracterizada por uma forte emoção que surge na busca de respostas diante de uma sociedade fragmentada.

O discurso religioso midiático deve servir para realçar significados já antes estabelecidos, principalmente quando surge através da sociedade de consumo; parece que os princípios permaneceram, porém, as embalagens mudaram drasticamente. $\mathrm{O}$ ascetismo que antes era pregado com veemência, tanto no catolicismo quanto no protestantismo, deu lugar para o hedonismo, o mundo que anteriormente era um local pecaminoso, agora deve ser usufruído na sua essência.

O discurso religioso pós-moderno tem características próprias: 1) Busca soluções imediatas para os problemas da vida; 2) As soluções geralmente estão nas pessoas e não no divino; 3) As incertezas das propostas fazem com que o sujeito busque em diversas religiões; 4) Os indivíduos passam a dar valor para o prazer, até mesmo o prazer religioso; 5) O futuro não deve ser levado em questão, sendo que a realidade é viver o presente, sem levar em conta também o passado; 6) O que faz o sujeito feliz é o desenvolvimento de suas capacidades

Levando isso em conta, com a quantidade de informações que o sujeito tem acesso e o desenvolvimento da tecnologia relacionada aos meios de comunicação, acaba-se produzindo cidadãos passivos, pessoas sem iniciativa, que vivem com a ideia de que o paraíso é o passageiro prazer de cada momento e as novidades de

\footnotetext{
${ }^{93}$ LYOTARD, J. F. O pós-moderno. Rio de Janeiro: José Olympio, 1986.

${ }^{94}$ MONTERO, Paula. Religiões, Modernidade e Cultura: novas questões. In: TEIXEIRA, Faustino; MENEZES, Renata (Orgs). As Religiões no Brasil: Continuidades e Rupturas. Petrópolis, RJ: Vozes, 2006. p. 1-28.
} 
consumo se transformam na realização do céu na terra. Na vida pós-moderna, objetos, informação e relacionamentos são descartáveis, os valores intrínsecos das coisas e das ações não são considerados como juízo de valor.

O cidadão pós-moderno vive uma "religião vazia" que se representa pelas exibições em massa através de shows, peregrinações turísticas, cultos televisivos etc. Tudo financiado por grandes investimentos nos meios de comunicação de massa e num nítido processo competitivo entre as diversas igrejas da sociedade.

O pluralismo religioso ${ }^{95}$ acompanha esse declínio da religiosidade, ou o novo vigor espiritual e a proposta do divino, agora reduzido a item de consumo e a uma proposta de serviços pessoais, baseado no carisma de determinados indivíduos.

Também não se pode negar que as atuais mudanças culturais exerceram um impacto relevante sobre o sujeito e têm resultado em um novo comportamento religioso na sociedade. Um fator que deve ser levado em conta é a questão de que não é o conteúdo religioso ou teológico do discurso que tem despertado a atenção do sujeito, mas o caráter individualista dos sujeitos religiosos e a possibilidade da prosperidade através da religião.

Isso atrai o sujeito hedonista e individualista. Max Weber ${ }^{96}$ já argumentava que, a despeito das implicações do pensamento racional e da modernidade, era praticamente impossível viver num mundo despojado de crenças. E mesmo que as profecias do iluminismo apontassem para tal realidade, os braços das velhas igrejas continuariam abertos para eles.

As igrejas da pós-modernidade são ávidas na busca pelo sujeito religioso plural, fragmentado, desejoso por uma experiência e que vivem migrando de um local para outro. Nesse meio surge a cultura midiática que serve como base para apresentar novas estratégias e táticas para o recrutamento de novos adeptos.

O discurso midiático, além dos bens que toda religião oferece, acentua a

\footnotetext{
${ }^{95}$ O pluralismo religioso é um fenômeno da sociedade pós- moderna que desafia o ser humano a viver de forma respeitosa com o diferente. É um novo paradigma que abre espaço às diversas cosmovisões religiosas e que, por meio do diálogo e alteridade, busca o entendimento, a paz e a tolerância entre os indivíduos. Pluralismo religioso representa a liberdade religiosa dos homens e a valorização de todas as manifestações religiosas. Assim, configura nosso tempo, marcado pela diversidade religiosa manifestando a multiplicidade de ideias e pensamentos entre os seres humanos em diversas culturas. Onde houver liberdade de expressão, liberdade religiosa, existirá pluralismo religioso. DUPUIS, Jacques. O Cristianismo e as religiões. São Paulo: Edições Loyola, 2004,p, 316.

${ }^{96}$ WEBER, Max. Ensayos sobre sociologia de la religión, 3 vol. Madrid: Taurus, 2001. p,11-24
} 
oferta diversificada de bens materiais em larga escala. Assim, o que era para ser uma apresentação religiosa, assume ares mercadológicos e busca atender aos anseios dos espectadores.

O conteúdo das mensagens veiculadas é preparado de acordo com os anseios do sujeito, promete-se o que os clientes (que acabam se tornando clientes consumidores) precisam. Assim, se o necessitado precisa de cura, vai encontrar opções para isso; se precisa libertar-se de algum vício, seguramente encontrará uma alternativa; se o problema é o desemprego, se a crise familiar se agrava, para todos esses dilemas da vida tais igrejas pós-modernas oferecem uma alternativa adequada para solucioná-los.

O atendimento das carências básicas do ser humano, acompanhado com o desejo de auto- realização e consumo exagerado, faz com que as igrejas da pósmodernidade usem as estratégias dos meios de comunicação de massa para convocar e arregimentar para suas instalações este novo sujeito pós-moderno religioso.

A religião apropria-se da cultura e dos processos midiáticos não só para manter "as velhas igrejas" como para consolidar "as novas crenças" a sua participação nesse novo mercado e apresentar-se de forma relevante para a sociedade. Tal ação gera uma reconfiguração no mercado, pois a religião se apresenta como uma alternativa a ser considerada em todos os aspectos da sociedade, seja econômico, tecnológico, entretenimento, de turismo etc.

Portanto, é preciso refletir sobre esse sujeito religioso pós-moderno, considerando as atuais necessidades da religiosidade, o que traz novos questionamentos que não podem ser respondidos sem levar em conta esses novos religiosos.

1) Estes novos religiosos não se preocupam mais com as limitações que possam ser impostas ao tipo de vestuário ou de costumes, e muito embora ainda creiam no dualismo do mundo espiritual, falam de Deus de forma diferente de seus antecessores. Os neopentecostais (como são assim chamados) pregam principalmente a prosperidade como meio verdadeiro de vida para os crentes.

2) Acreditam também que o mundo está tomado por demônios que lutam para destruir a abundância de Deus, e tentam, de forma sistemática e resignada, a expulsão desses demônios de suas vidas.

3) Para eles, doenças, pobreza e sofrimento são coisas que têm sua origem 
em satanás. Por isso, os cultos neopentecostais são em sua maioria carregados de forte emoção e costumeiramente objetivam uma libertação deste mundo satânico.

Atualmente, no Brasil, as igrejas classificadas como neopentecostais consideradas de maior expressão são as seguintes: Universal do Reino de Deus, Igreja Mundial do Poder de Deus, Internacional da Graça de Deus e Renascer em Cristo entre outras. Segundo Campos, os pesquisadores que estudam o campo religioso brasileiro sugerem também outros nomes para designar esse novo ramo do pentecostalismo, por exemplo: "agência de cura divina (MONTEIRO, 1979); "sindicato de mágicos" (MENDONÇA, 1992); "pentecostalismo autônomo" (BITTENCOURT, 1994); “pentecostalismo de terceira onda”, (FRESTON, 1993) ", entre outros. ${ }^{97}$

O fato é que várias igrejas neopentecostais têm despontado no cenário brasileiro. Chegam a fundar, conforme dados do Instituto de Estudos da Religião (ISER), apenas em um estado como o Rio de Janeiro, cinco igrejas por semana. Com o neopentecostalismo, surge uma nova mentalidade religiosa. Não é mais necessária a morte dos desejos do corpo para se desfrutar da glória e da felicidade celestial.

Deixa-se de lado o exclusivo desenvolvimento de um evangelho ascético que optava e defendia a mortificação da carne, o isolamento social de um mundo perdido e o confinamento espiritual como um tipo imprescindível de disciplina pessoal para o crente. As bênçãos divinas tornaram-se disponíveis através da prosperidade financeira, da saúde física e do sucesso nos empreendimentos terrenos. Os novos crentes já não se importam tanto com mudança de vida, moralmente falando. A preocupação básica agora é com prosperidade, saúde e felicidade neste mundo.

\subsection{O poder religioso e sua relação com o sujeito midiático}

O cristianismo é a única religião a se organizar como igreja. E como tal, postula o princípio de que certos indivíduos podem, por sua qualidade religiosa, servir a outros, não como príncipes, magistrados, educadores, benfeitores e

\footnotetext{
${ }^{97}$ CAMPOS, L. S. Teatro, templo e mercado: Organização e marketing de um empreendimento neopentecostal. Petrópolis-São Paulo: Vozes-Simpósio-Umesp, 1997.p,9-47
} 
adivinhos, mas como imitadores de Cristo. ${ }^{98}$

A pastoral, pois, no contexto do pensamento católico e protestante latinoamericano, refere-se à ação coletiva do povo de Deus, da igreja, cuja hierarquia principal é o bispo ou o pastor. A definição de uma linha relacionada ao poder religioso, inclui pelo menos quatro elementos: 1) a situação social, analisada através da perspectiva que surge da prática do povo crente; 2) a memória da fé; 3) a comunidade eclesial; 4) e a ordem do ministério que encontra sua culminância hierárquica no episcopado. ${ }^{99}$

O poder religioso, se não for bem-conceituado e assimilado da forma correta da parte daqueles que o detém, pode se tornar uma tragédia, tanto para o indivíduo quanto para aqueles que estiverem sendo conduzidos por ele. Um dos perigos deste século é o encanto com o "poder" (desejo de dominar). Alguém já disse: "O Poder é como água salgada, quanto mais se bebe mais se tem sede".

Paupério cita São Tomás de Aquino, “A legitimidade de um poder é determinada pela justiça de sua aquisição e de seu exercício. Neste caso, o poder deve ser a prática para o bem comum, sem contradizer, nunca, o bem divino". ${ }^{100}$

O poder religioso legítimo não é apenas uma forma de poder que comanda; deve também estar preparado para se sacrificar pela vida e pela salvação do rebanho. Portanto, é diferente do poder real que exige um sacrifício de seus súditos para salvar o trono. É uma forma de poder que não cuida apenas da comunidade como um todo, mas de cada indivíduo em particular, durante toda a sua vida. Esse poder contrasta com o poder real, em que a figura do rei passa a ser o centro das atenções. No poder religioso, a principal figura é a do verdadeiro e superior rei-Deus, criador dos céus e da terra, único digno de adoração e a principal razão da existência da religião cristã. Essa, por sinal, é a expressão de vida de seu fundador, Jesus Cristo, que deu sua vida em favor de seus seguidores. Ele morreu, ressuscitou e está vivo para todo aquele que nEle crer.

O poder religioso tem uma dimensão política. Com isso, pretende-se dizer que o poder religioso está relacionado com o poder institucional. Os líderes da sociedade, uma vez que precisam da religião para santificar os valores sociais e

\footnotetext{
${ }^{98}$ FOUCAULT, M. O Sujeito e o Poder. Rio de Janeiro: Graal. 1999. p. 38.

${ }^{99}$ ANA, Júlio Santa de. Pelas Trilhas a Caminho do Reino. São Paulo: Imprensa Metodista, 1998. p. 30.

100 PAUPÉRIO, A. M. Teoria Democrática da Soberania. Rio de Janeiro: Florense Universitária, 1997. p. 39.
} 
apoiar o controle social, tendem a se proteger de ameaças da religião e as instituições religiosas. Os "poderosos" se entendem e fazem arranjos, geralmente, sem que o povo saiba o que está acontecendo.

Os profetas de Israel tinham a responsabilidade de conduzir o povo, de acordo com os princípios ensinados por Deus. Não eram discriminados por isso. "Assim surge a possibilidade de uma identificação entre autoridades religiosas e seculares. Essa situação, como se pode ver na história da religião, reúne o poder secular e o religioso em busca de interesses comuns". ${ }^{101}$

O poder religioso comprometido com as estruturas de poder passa a ser manipulador devido ao fato de trabalhar com o místico, com o simbólico e despertar as paixões humanas. Nesse caso, a figura daquele que exerce o poder assume formas das mais distintas, chegando a ponto de ser cultuado por seus admiradores. Estes, por sua vez, se deixam encantar com o poder, se deixam levar pelo fascínio e pela sedução, resultando numa trágica influência de consequências diversas e, no final, catastróficas.

Como se exerce o poder? Não há, portanto, um confronto entre poder e liberdade numa relação de exclusão (onde o poder se exerce, e a liberdade desaparece). Contudo há um jogo muito mais complexo. Nesse jogo, a liberdade aparecerá como condição da existência do poder, ao mesmo tempo a sua pré-condição, uma vez que é necessário que haja liberdade para que o poder se exerça, e também seu suporte permanente, já que, se ela se abstraísse inteiramente do poder que sobre ela se exerce, por isso mesmo desapareceria, e deveria buscar um substituto na coerção pura e simples da violência. Ela, porém, aparece também como aquilo que só poderá se opor a um exercício de poder que tende, enfim, a determiná-la inteiramente. ${ }^{102}$

John Naisbitt observou no livro Megatrends (Megatendências) que movimentos significativos começam de baixo para cima, não de cima para baixo. Transformações culturais realmente importantes começam, não a partir daqueles que ocupam cargos de destaque ou de celebridades, mas através de indivíduos comuns. Cada pessoa pode - e deve - buscar fazer diferença em seu canto do mundo, ajudando pessoalmente os que têm necessidade. Isso, de certa forma, é exercer poder, intervindo na sociedade, fazendo a diferença para outros, interagindo em situações nas quais estamos envolvidos ou envolvendo outros que precisam de ajuda.

\footnotetext{
${ }^{101}$ O’DEA, Thomas F. Sociologia da religião. São Paulo: Pioneira, 1969. p. 134.

${ }^{102}$ FOUCAULT, M. O Sujeito e o Poder. Rio de Janeiro: Graal. 1999. p. 39.
} 
O poder religioso na sua essência deve ser exercido a favor dos outros, não visando seus interesses pessoais nem oprimindo ao fraco. Um senhor de escravos ou um senhor feudal transplantado da Antiguidade para o mundo de hoje acharia difícil acreditar, e até espantoso, que os trabalhadores não apanham e ainda produzem mais. ${ }^{103} \mathrm{O}$ poder religioso não deve explorar o mais fraco, nem impor sua força sobre aqueles que não têm como reagir.

O Estado moderno ocidental integrou, numa nova forma política, uma antiga tecnologia de poder, originada nas instituições da fé. Pode-se chamar essa tecnologia de "poder pastoral". Essa é uma das alternativas de poder praticadas pelos líderes religiosos. A figura pastoral é muito forte nesse ambiente e a pessoa que a exerce passa a ter uma grande influência perante aqueles que estão inseridos na sua comunidade de fé. Esse indivíduo que encarna a tarefa pastoral assume um destaque perante os fiéis, e muitas expectativas são geradas em torno dessa tarefa. Os sujeitos relacionados a determinadas comunidades religiosas, anseiam, desejam e esperam posturas dignas do cargo ocupado.

Michel Focault assim conceitua o poder pastoral:

Esta forma de poder aplica-se à vida cotidiana imediata que categoriza o indivíduo, marca-o com sua própria individualidade, liga-o à sua própria identidade, impõelhe uma lei de verdade, que devemos reconhecer e que os outros têm de reconhecer nele. É uma forma de poder que faz dos indivíduos sujeitos. Há dois significados para a palavra sujeito: sujeito a alguém pelo controle e dependência, e preso à sua própria identidade por uma consciência ou autoconhecimento. Ambos sugerem uma forma de poder que subjuga e torna sujeito subserviente ${ }^{104}$

Essa conceituação de Michel Focault pressupõe algumas considerações para aqueles que pretendem exercer ou que já exercem o poder pastoral, pressupõe-se um relacionamento sério e profundo com aqueles que se dedicam a seguir a vocação pastoral. O trabalho é árduo, muito abrangente, exige capacitação em diversas áreas, tanto no campo da psicologia como no das ciências sociais e, principalmente, no da teologia bíblica. Cabe à figura pastoral orientar sem manipular; exercer poder sempre visando o bem comunitário; deve zelar pelos princípios da Palavra de Deus; e desenvolver habilidades no trato com outros.

Essa forma de poder é orientada para a salvação (por oposição ao poder político). É oblativa (por oposição ao princípio da soberania). É individualizante (por oposição

\footnotetext{
${ }^{103}$ TOFFLER, Alvin. As Mudanças do Poder. Rio de Janeiro: Record, 1990. p. 66.

${ }^{104}$ FOUCAULT, Michel. Microfísica do poder. Rio de Janeiro: Edições Graal, 1979. p. 38
} 
ao poder jurídico). É também co-extensiva à vida e constitui seu prolongamento. Está ligada à produção da verdade - a verdade do próprio indivíduo. Mas podemos dizer que tudo isso faz parte da história. A pastoral, se não desapareceu, pelo menos perdeu a parte principal de sua eficácia. De certa forma, podemos considerar o Estado como a matriz moderna da individualização ou uma nova forma do poder pastoral. $^{105}$

Com o passar do tempo, a figura e as tarefas pastorais têm sido distorcidas pela profissionalização daqueles que exercem tais funções. Em outras palavras, o poder "legítimo" (reconhecido pelo povo) deu lugar ao poder da instituição. E a figura pastoral, resultante da vocação cristã, deu lugar ao "especialista da religião" (a figura resultante dos modelos estruturais religiosos, que passou pelas escolas da religião), e perdeu a paixão pela salvação e pelo serviço à comunidade.

Há mais algumas questões sobre esse poder pastoral. Pode-se observar uma mudança em seu objetivo. Já não se trata mais de uma questão de dirigir o povo para sua salvação no outro mundo, mas, antes, assegurá-la neste mundo. Alguns dizem que vivemos numa realidade que terminou com as utopias, não existe mais lugar para o sonho e a esperança do porvir. O famoso comentário de Lord Acton: "O poder tende a corromper, e o poder absoluto corrompe absolutamente", tornouse um jargão após um século da filosofia nietszcheniana "vontade de potência", no despertar da "morte de Deus". Friedrich Nietszche, o filósofo alemão do século passado, predisse esta era e argumentou que, de agora em diante, poder, e não persuasão, a ideologia, e não a doutrina religiosa preencheriam o vácuo deixado pelo esvaziamento de significado do cristianismo. ${ }^{106}$

A figura pastoral tem esta finalidade: gerar e canalizar sonhos, exercer um poder benevolente que incentive os outros a encontrar seu espaço na sociedade, e a servir ao próximo da melhor maneira possível.

Qualquer pastor que deixe de proteger seu povo com os cuidados e ensinos bíblicos, que não consiga distinguir um lobo na pele de um carneiro ou cordeiro, subestima imensamente as responsabilidades de sua posição. As destrutivas e falsas doutrinas e os erros graves de conduta dispersam o rebanho ou levam-no para uma armadilha ou a um precipício para sua destruição. ${ }^{107}$

Esse modelo traz consigo implicações distintas e variadas. A figura da igreja e da comunidade religiosa passa a ser transferida para uma estrutura política e social. Com o passar dos tempos de uma série de novas instituições sociais, a igreja, através de sua figura pastoral, vai se deixando fragmentar no seu nível de influência, provocando reações das mais diversas na sociedade.

\footnotetext{
${ }^{105}$ FONSECA, M. A. Michel Focault e a constituição do sujeito. São Paulo: EDUC, 2011.p,23

${ }^{106}$ HORTON, M Religião do Poder. São Paulo: Cultura Cristã, 1998. p. 11.

${ }^{107}$ SHEDD, R. I Pedro, Abordagens Pastorais. São Paulo: Vida Nova, 1983. p. 87.
} 
As situações tem sido alteradas com o passar dos tempos, pois o líder sindical, o lider do movimento dos sem-terra, o gerente financeiro de um determinado banco e outras figuras da sociedade passaram a exercer uma influência mais objetiva e mais constante nas comunidades do que aquele que exerce a tarefa pastoral. Por outro lado, também se pode constatar que as funções pastorais, bem trabalhadas e articuladas, podem fazer uma grande diferença quando são desempenhadas numa perspectiva abrangente e social, tornando-se participante das diferentes classes, com uma proposta teológica contextualizada e conservando os valores das escrituras.

E isto implica que o poder pastoral, que durante séculos - por mais de um milênio - foi associado a uma instituição religiosa definida, ampliou-se substancialmente por todo o corpo social; encontrou apoio numa multiplicidade de instituições. E, em vez de um poder pastoral e de um poder político, mais ou menos ligados um ao outro, mais ou menos rivais, havia uma "tática" individualizante que caracterizava uma série de poderes: da família, da medicina, da psiquiatria, da educação e dos empregadores. ${ }^{108}$

Maquiavel propõe um modelo de poder totalmente distinto do proposto por Jesus e pelas Escrituras. Para ele, um príncipe deve aconselhar-se sempre, mas quando ele queira, e não quando os outros desejem. Antes, deve se tolher a todos os desejos de aconselhar-lhe para alguma coisa sem que ele venha a pedir. Em seu modelo a figura pastoral não tem traços de humildade, mas exerce um poder manipulador perante aqueles com os quais ele convive. Mas ele deve ser um grande perguntador e, depois, acerca das coisas questionadas, paciente ouvinte da verdade. No entanto, se notar que alguém, por algum motivo, não lhe diz a verdade, deve mostrar aborrecimento. ${ }^{109}$

O relacionamento com seus subordinados deve ser conduzido a partir de paixões e sentimentos fortes. Os outros devem estar conscientes de que ele é a figura principal, ele deve se sentir bem. Quando não for assim, o benefício decorrente do cargo ocupado não chega até ao povo.

Há muitos que entendem que o príncipe que dá de si opinião de prudente, seja assim considerado, não pela sua natureza, mas pelos bons conselhos que o rodeiam. Contudo, sem dúvida nenhuma, estão enganados. Eis que esta é uma regra geral que nunca falha: um príncipe que não seja sábio por si mesmo não pode ser bem

\footnotetext{
${ }^{108}$ DREYFUS, H. L.; RABINOW, P. Michel Foucault. Uma trajetória filosófica para além do estruturalismo e da hermenêutica. Rio de Janeiro: Forense Universitária, 1995 p p,38

${ }^{109}$ MAQUIAVEL, Nicolau, O Príncipe, Companhia das Letras, 2010, p,176
} 
aconselhado, a menos que, por acaso, confiasse em um só que de todo o governasse e fosse homem de extrema prudência. Essa alternativa poderia bem acontecer, mas duraria pouco, porque aquele que efetivamente governasse, em pouco tempo, lhe tomaria o Estado. Mas, aconselhando-se com mais de um, o príncipe que não seja sábio não terá nunca os conselhos uniformes e não saberá por si mesmo harmonizálos. Cada conselheiro pensará por si e ele não saberá corrigi-los nem se inteirar do assunto. E não é possível encontrar conselheiros diferentes, porque os homens sempre serão maus se, por uma necessidade, não forem tornados bons. Consequentemente conclui-se que os bons conselhos, venham de onde vierem, devem nascer da prudência do príncipe, e não a prudência do príncipe resultar dos bons conselhos. ${ }^{110}$

Não se considera a possibilidade bíblica que diz: Na multidão de conselhos há sabedoria (Provérbios 24,6). Além disso, o líder não pode expor suas limitações perante seus liderados. Se fizer isso, ele corre o risco de perder o poder. Então se constata que esse poder exercido não é genuíno, foi conquistado pela força do cargo, por tradição, por herança etc.

Deduz-se, portanto, que a figura pastoral é forte e exerce um poder abrangente porque conta com as estruturas religiosas a seu favor. Cabe àqueles que exercem o poder pastoral estarem fundamentados no "modelo bíblico de poder" (conduzir outros a salvação), servir à comunidade e incentivar os sonhos e a esperança do povo; esses princípios representam o poder genuíno.

O desafio contemporâneo para a figura pastoral é não se deixar levar nem ceder aos encantos da pós- modernidade, que na verdade não propõem muita coisa nova, mas incentivam a repetição dos modelos tiranos desenvolvidos no decorrer da história. A religião é um excelente palco para que indivíduos com más intenções e com sede de poder se estabeleçam sobre muitos, em nome de Deus, mas agindo para si.

Os pastores devem tomar o cuidado de evitar o abuso de poder, não serem "dominadores dos que vos foram confiados". Muitos cristãos elevam os pastores a um alto pedestal. Alguns chegam até a adorar o homem que Deus tem usado poderosamente para transformar vidas. A adulação indevida encoraja o líder a manipular os membros da igreja, abusando de sua autoridade. Tais pastores são como os "falsos apóstolos" que perturbavam a igreja de Corinto (2 Co 11.13). Jesus advertiu seus discípulos quanto à tentação universal de "reinar" (Lc 22.25). Era um mau exemplo a famosa maneira pela qual os governantes romanos intimidavam e forçavam os subordinados a submeter-se a exigências opressivas. ${ }^{11}$

Há a necessidade de referenciais como o de João Wesley (século XVIII), a quem Deus escolheu para proclamar a mensagem cristã na Inglaterra. Ele percebeu que o evangelho é o poder de Deus para libertar o povo inglês da

\footnotetext{
${ }^{110}$ MACHIAVELLI, N. B. D. O Príncipe. Rio de Janeiro: Civilização Brasileira, 1976. p. 132.

${ }^{111}$ SHEDD, R. Nos Passos de Jesus. São Paulo: Vida Nova, 1993. p.93.
} 
opressão da escravidão, dentre outros pecados. No poder do evangelho do reino de Deus, ele enfrentou principados e potestades da economia, da política e da religião. E os enfrentou com a vontade divina que não deseja que nenhum dos seus pereça, mas que todos sejam salvos e libertos do grilhão da morte. Sua obra teve grande repercussão junto ao povo oprimido e empobrecido. Este é um modelo pastoral a ser seguido: interagir na sociedade, seguir um mandado de Deus e fazer a diferença, apresentando um evangelho que seja orientador, libertador e capaz de gerar esperança.

\subsubsection{Da valorização do carisma pessoal ao culto a pessoa}

A partir da consolidação do valor do corpo e das aparências, destaca-se o carisma de certos indivíduos que fazem uso dela para manipular a muitos. Uma pertinência cabível a ser considerada no poder religioso se relaciona entre o poder e o carisma.

Como sempre, nas relações de poder, nos deparamos com fenômenos complexos que não obedecem à forma hegeliana da dialética. O domínio e a consciência do próprio corpo só puderam ser adquiridos pelo efeito do investimento do corpo pelo poder: a ginástica, os exercícios, o desenvolvimento muscular, a nudez, a exaltação do físico belo, tudo isso conduz ao desejo do próprio corpo através de um trabalho insistente, obstinado e meticuloso que o poder exerceu sobre o corpo das crianças, dos soldados, sobre o corpo sadio. Mas, a partir do momento em que o poder produziu esse efeito, como consequência direta de suas conquistas, emerge inevitavelmente a reivindicação do próprio corpo contra o poder; a saúde contra a economia; o prazer contra as normas morais da sexualidade, do casamento, do pudor. E, assim, o que tornava forte o poder passa a ser aquilo por que ele é atacado. O poder penetrou no corpo, encontra-se exposto ao próprio corpo. $^{112}$

Portanto, um poder que está além da aparência externa das coisas e dos acontecimentos cotidianos pode ser percebido pelos homens, tanto em sua experiência do extraordinário quanto do estabelecimento.

Esse ambiente é propício para as personalidades manipuladoras que trabalham com indivíduos "alienados" (tipo seita, totalmente fora da realidade). A partir desse modelo, surge a figura do carismático. Weber define o carisma como certa qualidade de uma personalidade individual, e em virtude da qual se separa de homens comuns e é tratada como se fosse de qualidades ou poderes

\footnotetext{
${ }^{112}$ FOUCAULT, M. Microfísica do poder. Rio de Janeiro: GRAAL, 1999. p. 146.
} 
sobrenaturais, sobre-humanas ou, pelo menos, especificadamente excepcionais. Tais qualidades não são acessíveis as pessoas comuns, mas são vistas como de origem divina ou exemplares, e a partir delas o indivíduo é tratado com certo destaque. ${ }^{113}$

Alguns indivíduos fazem uso de suas habilidades naturais para tomar vantagens sobre outros. Neste sentido o poder religioso passa a ser como uma ferramenta em busca de vantagens pessoais.

É evidente que a origem do poder está na força. Os primeiros grupos de seres humanos que cruzaram pela terra eram dirigidos e comandados por aqueles que eram mais fortes que os outros; graças às suas qualidades físicas e ao seu valor, se impunham aos demais. "Provavelmente realizavam façanhas perigosas para aquela época e, por isso, surgiu a ideia de que possuíam qualidades sobrenaturais e de que as sociedades primitivas consideravam que o chefe era um deus. O poder estava ligado à sua pessoa, emanado por uma força sobrenatural". 114

Maquiavel leva essa tese ao extremo quando o "príncipe", seu personagem principal no livro, deve concentrar-se no exercício de poder sem devaneios: "Deve o príncipe, portanto, não se desviar nem um momento sequer do seu pensamento o exercício da guerra. Cabe ao Príncipe fazer isso de duas maneiras: uma com a ação, e a outra com a mente". ${ }^{115}$

Para exercer funções relacionadas com o poder, deve-se partir do pressuposto de que se sabe o que está se fazendo, que o indivíduo tenha domínio de seu campo de ação, tenha vontade, vença o cansaço, exerça a voluntariedade e aja com disposição de superação. O exercício do poder não existe num vazio casual, está inserido em contextos intensos e com propósitos diversos.

Quando definimos o exercício do poder como um modo de ação sobre as ações dos outros, quando as caracterizamos pelo "governo" dos homens, uns pelos outros no sentido mais extenso na palavra, incluímos um elemento importante: a liberdade. O poder só se exerce sobre "sujeitos livres", enquanto são livres entendendo-se por isso sujeitos individuais ou coletivos que têm diante de si um campo de possibilidades onde diversas condutas, várias reações e diferentes modos de comportamento podem acontecer. Não há relação de poder onde as determinações estão saturadas. A escravidão não é uma relação de poder, pois o homem está acorrentado (trata-se então de uma relação física de coação) - mas

\footnotetext{
${ }^{113}$ O’DEA, T. Sociologia da religião. São Paulo: Pioneira, 1969. p. 34.

${ }_{114}$ MENDIETA, L. N. Sociologia de Poder. México: Universitária, 1976. p. 21.

${ }^{115}$ MACHIAVELLI, N. B. D. O Príncipe. Rio de Janeiro: Civilização Brasileira, 1976. p. 86.
} 
apenas quando ele pode se deslocar e, no limite, escapar. ${ }^{116}$

O interesse e veneração de personalidades acontece geralmente no campo religioso. Certos indivíduos com um grau acentuado de carisma individual, promovem sua pessoa ao ponto que passam a ser admirados de forma exagerada, modelos gerencias de governo e liderança passam a ser adotados no ambiente religioso. O povo de maneira geral não tem muito critério para separar a idolatria do respeito e admiração.

O surgimento do tele-evangelismo e dos ministérios de pregação tem levado a um culto crescente de personalidades dentro do evangelismo de poder. Isso é verdade não apenas nos ministérios de mídia como também nas apresentações que as celebridades religiosas fazem regularmente em eventos e megaigrejas. Não é o que as Escrituras ensinam que realmente importa; mas o que fulano de tal tem a testemunhar sobre suas experiências e ideias. Até mesmo para alguns líderes, não vale o que dizem as Escrituras, mas o que o comunicador disse que diz as Escrituras é isso que vale. Em determinadas situações a Bíblia é ignorada; só é valorizado o que Deus está falando através desse comunicador. Mas, como verificar sua mensagem? Como ter certeza de que ele está falando no nome do Senhor, e não simplesmente usando de uma autoridade espúria às suas próprias ideias? Devemos nos lembrar de que o pecado original foi querer ser como Deus. ${ }^{117}$

Depara-se, nesse caso, com uma constatação: o ambiente religioso é uma terra fértil para o uso inadequado do poder. Deveria ser impensável para qualquer indivíduo crer que ele próprio possa ser um objeto merecedor de culto público.

Seria como se o burro, carregando Jesus para Jerusalém, acreditasse que fosse a ele que a multidão aclamava, e que para ele as vestes foram estendidas no chão. Contudo as vantagens e a adulação do público, que acompanham a exposição da televisão, são suficientes para inflar o ego da maioria das pessoas. Isso leva ao uso autoindulgente do poder, que alguns, com razão, chamam de "síndrome de Imelda Marcos", que dizia: "Porque estou nesta posição, tenho o direito de fazer o que queira", com total egoísmo e desrespeito pelos outros. ${ }^{118}$

O indivíduo cultuado, que não tem um referencial correto para exercer as funções decorrentes da liderança religiosa, torna-se uma vítima de si mesmo e das estruturas nas quais está inserido. Na ânsia de fazer o melhor, assume posturas humanas e às vezes contraditórias à Bíblia. Buscando seus interesses egoístas e transitórios, ele se concentra naquilo que passa a ser mais o mais interessante e

\footnotetext{
${ }^{116}$ FOUCAULT, M. O Sujeito e o Poder. Rio de Janeiro: Graal. 1999. p. 39.

${ }^{117}$ HORTON, M. Religião do Poder. São Paulo: Cultura Cristã, 1998. p. 25.

${ }^{118}$ HORTON, M. Religião do Poder. São Paulo: Cultura Cristã, 1998. p. 22.
} 
cômodo para seus projetos pessoais. E assim se esquece da vocação cristã e repudia os princípios divinos, porque esses não satisfazem às suas expectativas existenciais.

Não se está sugerindo com isso que todo comunicador, dentro da tradição do que se chama evangelicalismo de poder, esteja enganando ou vagando em algumas viagens do ego. Mas é bom lembrar que a ênfase colocada sobre a pregação individual e ministério profético é vulnerável à exploração humana pecaminosa. No fundo do nosso ser, nossos velhos desejos de pecado nos levam de volta a nós mesmos e permanecem em lugares não conquistados pela graça. $\mathrm{O}$ evangelicalismo de poder é vulnerável nesse ponto. Por quê? Porque estimula tanto os comunicadores quanto a comunidade deles a esperar que alguns indivíduos tenham capacidade de declarar - com certo grau de infalibilidade que faria qualquer líder moderno invejar - o que exatamente é a vontade de Deus para o seu povo. ${ }^{119}$

As estruturas religiosas passam a exigir determinadas posturas daqueles que estão à frente e que exercem algum tipo de influência. A figura do líder religioso dentro desse contexto (tanto homens quanto mulheres) pressupõe infalibilidade. Espera-se que o indivíduo esteja preparado para todas as circunstâncias e situações da vida; onde não se pode errar. É desenvolvido um modelo no qual o grande líder que fugir do "normal" (as convenções desenvolvidas pela religião) está fora do sistema e dificilmente conseguirá se recuperar. Não se desenvolve um modelo que vise a resgatar aquele que enfrentar dificuldades, a pregação do evangelho não passa pelo serviço cristão.

O surgimento do tele evangelismo e dos ministérios de pregação de massa tem levado a um culto crescente de personalidades dentro da ideia de um evangelismo de poder. Isso é verdade não apenas nos ministérios de mídia como também nas apresentações que as celebridades cristãs fazem regularmente em eventos e megaigrejas. $\mathrm{O}$ parecer de um dos entrevistados a respeito do assunto serve de luz para esclarecer os eixos para aqueles que exercem o ministério midiático.

A importância da mídia para vida pastoral, precisamos entender a realidade de hoje
as redes sociais, web, rádio, tv aberta e fechada. Como formador de opinião,
compreendo que o ser humano é um ser social e tenho interesse de mudar a
sociedade falando da fé e de Deus, tudo isso tem impacto na vida pastoral, todos os
veículos de comunicação estão no dia a dia de todo cidadão, a internet vai a todos
os pontos do país, porque não atingir aqueles lugares de sombra, porque não atingir
com a rádio e a tevê porque não atingir, com as rádios difusoras de AM e FM, eu
vejo como uma ferramenta fundamental para a ação pastoral, o negativo e o

${ }^{119}$ HORTON, M. Religião do Poder. São Paulo: Cultura Cristã, 1998. p.25. 
positivo de toda essa ação. Eu não sei quem está me assistindo, mas eu compreendo que vou impactar alguém de uma forma ou de outra, quem não se interessa pelo assunto pode desenvolver um senso crítico. Sem perder a realidade daquele que é um ser social. Eu continuo indo à padaria perto da minha comunidade, faço almoço e janta na padaria e lanches e tenho o convívio na vida comum, circulando junto à comunidade no meu espaço pastoral, com a liberdade de caminhar com o povo tenho a ideia que esse ministério não é para estrelismo, não sou artista, atuo como padre, não pretendo ser artista. Fama e lama caminham juntas. Será que estimulamos o fanatismo, se existe idolatria, será que nós somos responsáveis por isso. Precisamos equilibrar fé e razão. ${ }^{120}$

Assim deve ser a postura de um comunicador midiático, não se deixar envaidecer, ser consciente de sua missão e tarefa. Cabe àquele que exerce essa tarefa compreender a dimensão de sua ação, pois milhares de pessoas são influenciadas em locais às vezes inimagináveis, portanto, o posicionamento e a atitude devem ser autênticos e de acordo com os padrões cristãos.

\begin{abstract}
Humildes, literalmente "de pensamento baixo, pensando pouco (de si)". No mundo grego a humildade geralmente era percebida como algo indigno. Para aquele, porém, que foi chamado por Jesus para segui-lo, ser humilde não representa mais um ultraje. E quem experimentou a condescendência de Deus, volta-se ao pequeno com alegria de ajudar e salvar. Somente quem é humilde pode dar honras a Deus. Sem humildade tampouco é possível uma vida eclesial saudável, porque orgulho provoca orgulho, teimosia e vaidade. Em outras palavras: onde vigora a humildade está dada a premissa para a misericórdia e cooperação fraternais. Para compreender todas as exortações. É importante ver que aqui estão em jogo características essenciais que não é possível ter sem que elas se transformem em atos. ${ }^{121}$
\end{abstract}

Às vezes a Bíblia tem sido ignorada; só é valorizado o que Deus está falando pessoalmente para determinado pregador. Mas, como verificar sua mensagem? Como ter certeza de que ele está falando no nome do Senhor, e não simplesmente dando autoridade espúria às suas próprias ideias? Deve-se lembrar de que o pecado inicial foi querer ser como Deus. ${ }^{122}$

Contudo as vantagens e a adulação do público, que acompanham a exposição da televisão, são suficientes para inflar o ego da maioria das pessoas. Isso leva ao uso autoindulgente do poder, que alguns, com razão, chamam de "síndrome de Imelda Marcos", que dizia: "Porque estou nesta posição, tenho o direito de fazer o que quero", com total egoísmo e desrespeito pelos outros. ${ }^{123}$

O indivíduo cultuado, que não tem um referencial correto para exercer as

\footnotetext{
${ }^{120}$ Apêndice 1, Entrevistas, S3, 2016, p. 203.

${ }^{121}$ HOLMER, Uwe. Primeira Carta De Pedro. Comentário Esperança. Curitiba, 2008. p. 225.

${ }^{122}$ HORTON, Michael. Religião do Poder. São Paulo: Cultura Cristã, 1998. p. 25.

${ }^{123}$ HORTON, Michael. Religião do Poder. São Paulo: Cultura Cristã, 1998. p. 23.
} 
suas funções decorrentes da liderança pastoral, torna-se uma vítima de si mesmo e das estruturas nas quais está inserido. $\mathrm{Na}$ ânsia de fazer o melhor, assume posturas humanas e às vezes contraditórias à Bíblia. Buscando interesses humanos e transitórios, e se concentra naquilo que passa a ser mais interessante e cômodo para seus projetos pessoais. Agindo dessa forma se esquece da vocação cristã e repudia os princípios divinos, porque estes não satisfazem às suas expectativas existenciais.

Por quê? Porque estimula tanto aos pregadores quanto a congregação deles a esperar que alguns indivíduos tenham capacidades de declarar - com certo grau de infalibilidade - o que exatamente é a vontade de Deus para o seu povo. ${ }^{124}$

As estruturas religiosas passam a exigir determinadas posturas daqueles que estão à frente e exercem algum tipo de influência. A figura pastoral dentro desse contexto (tanto homens quanto mulheres) pressupõe infalibilidade. Espera-se que a pessoa que exerce essa função esteja preparada para todas as circunstâncias e situações da vida; não se pode errar. É desenvolvido um modelo de tal forma que o pastor (a) não pode sair do "normal" (as convenções desenvolvidas pela religião) estão fora do sistema e dificilmente conseguirão se recuperar. Não existe um modelo que vise ajudar aqueles que enfrentam dificuldades nessa área.

A cultura do exercício pastoral junta as mãos na ânsia de reconhecimento, poder e conquista, deixando o pastor midiático numa encruzilhada na qual, só pela quebra das barreiras numéricas, sua igreja será válida e agradará a Deus. A parte mais sedutora de tudo isso é que essas coisas jamais são ditas pelos líderes do movimento de crescimento de igreja. Na verdade, eles provavelmente rejeitaram tais ideias. Ainda assim, essa é a mensagem não falada que é comunicada através do corpo docente e dos currículos relacionados com esses temas. ${ }^{125}$

Pode-se constatar que uma estrutura religiosa tem sido montada para sustentar tais papéis. O líder religioso pactua com o modelo, em que o poder tem espaço para crescer e parte em busca da fama e do reconhecimento.

É superficial considerar que apenas os altamente dotados "brilham e fazem acontecer". Muitos pastores cheios de carisma permanecem fiéis aos princípios da disciplina e da piedade. Alguns deles chegaram ao "sucesso" após anos de duro

\footnotetext{
${ }^{124}$ HORTON, Michael. Religião do Poder. São Paulo: Cultura Cristã, 1998. p. 25.

${ }^{125}$ HORTON, Michael. Religião do Poder. São Paulo: Cultura Cristã, 1998. p. 25
} 
aprendizado, depois de lutar, perseverar e repensar as várias coisas. ${ }^{126}$

Há pessoas sérias que desempenham as funções pastorais midiáticas sem estarem encantadas com o poder. Buscam de fato servir sua comunidade, alinhados com os princípios bíblicos apresentados por Jesus. Apesar da falta de carisma ou de "brilho pessoal" (simpatia ou facilidade de conviver com o público), conseguem superar suas dificuldades e desenvolver um ministério significativo.

A falha de muitos líderes cristãos é que a devoção simples, que os trouxeram ao sucesso, já não existe mais, foi perdida com as atividades cotidianas. Não obstante, muitos pastores e líderes qualificados têm permanecido fiéis; não se pode confundir a pessoa que é dotado e criativo, com desvio de conduta. ${ }^{127}$ É preciso permanecer com uma ação pastoral duradoura, que não se deixe levar pelas tendências e por aspectos da secularização que comprometem os princípios do reino de Deus.

A chave para "formar" líderes cristãos autênticos é a partir dos princípios, não de modelos. Com frequência, se permite que os "técnicos" pensem pela igreja, da mesma maneira do que já acontece em muitas áreas da vida - com políticos, terapeutas, consultores de finanças e outros - até que, finalmente, não exista espaço para o próprio trabalho. Pastores e líderes de igreja, porém, devem pensar por si mesmos sobre sua metodologia de ministério e suas atividades.

E uma filosofia de ministério deve nascer da teologia de cada um. Essa corrida desenfreada para os "modelos funcionais de sucesso" e uma busca desenfreada pelo novo "cálice sagrado" pragmático do evangelicalismo. Não importa o quanto seja fraca e redundante a minha pregação, ou que a ação reflita a falta de planejamento e esforço; a pergunta ou busca de muitos: Deve haver uma maneira rápida e fácil de fazer uma igreja crescer $?^{128}$

\footnotetext{
${ }^{126}$ HORTON, Michael. Religião do Poder. São Paulo: Cultura Cristã, 1998. p. 25.

${ }^{127}$ HORTON, Michael. Religião do Poder. São Paulo: Cultura Cristã, 1998. p. 25

${ }^{128}$ HORTON, Michael. Religião do Poder. São Paulo: Cultura Cristã, 1998. p. 25
} 


\subsection{Conclusão}

O poder é uma realidade incontestável! Sua força e influência estão em toda a parte, o cidadão comum não é consciente de sua presença, a virtude principal do poder é o fato de ser invisível.

Há um sistema complexo que responde a interesses diversos que procura atender a suas demandas e fazer com que a sociedade responda de maneira satisfatória. Quando esses interesses não são atendidos, acontecem diversas consequências sobre o cidadão e os diferentes sistemas que fazem a sociedade funcionar.

A procura por uma sociedade mais justa e igualitária deve fazer parte da vida do cristão, onde o cidadão tenha voz, em que os sistemas não sejam opressores ou totalitários, de forma que cada membro da sociedade possa se fazer representar ou representar o outro, tendo como base os valores e princípios apresentados pela palavra de Deus.

A busca por um poder santo de uma inspiração divina e desenvolver um sistema de valores e crenças que se assemelhe ao reino de Deus, onde as pessoas possam viver em paz e contribuir para o bem geral de todos, um poder que se manifeste através do serviço e atenda às necessidades das pessoas.

O ambiente da religião precisa se manter puro, sem se deixar contaminar pelos sistemas manipuladores das instituições midiáticas e os grandes oligopólios do poder de comunicação. A agenda da sociedade deve ser pautada pela justiça e a solidariedade entre os povos.

O ministério cristão midiático corre o risco de seguir os mesmos padrões apresentados pela sociedade pós-moderna, a idolatria pessoal, a vida pautada por símbolos e imagens, a competição desregrada onde o poder deve ser conquistado a qualquer preço. Cabe aqueles que exercem o ministério cristão praticarem o poderserviço, aproveitando todas as oportunidades que a sociedade pós-moderna oferece, no que diz respeito aos recursos para comunicação. As regras para o serviço são outras os princípios estão ensinados nas escrituras sagradas. 


\section{O Poder-serviço: uma leitura bíblico-teológica}

Neste capitulo estudar-se-ão as fundamentações conceituais a respeito do poder, começando com as terminologias adequadas para melhor entendimento a respeito do assunto.

Após conceituação técnica serão analisados os aspectos teológicos a respeito do poder, abordando tanto os eixos da teologia quanto das ideologias, tendo em vista o ambiente da religião e seu diálogo como a teologia, em especial no contexto latino americano, onde será fundamentada a plataforma de análise.

Outra análise será feita a respeito da teologia do poder ou o poder e a teologia. A partir da teologia, percebe-se que o poder é neutro, depende do caráter de quem o exerce; será abordada a questão sobre as tentações a respeito do poder, o domínio e a exploração sobre os mais fracos. A questão ética é fundamental para que o exercício do poder aconteça de acordo com os princípios ensinados por Deus, e será apresentado um estudo a esse respeito.

É necessário, então, realizar uma análise do poder como serviço, pois podese se dizer que a consolidação genuína do poder acontece quando o serviço se torna evidente. Tomando como base o que foi ensinado por Jesus, que deixou, no Seu ministério, exemplos a serem seguidos, em especial quando assume a posição de servo. O Mestre demonstra interesse de ajudar e servir ao próximo, dando exemplos que ultrapassam os limites da história.

Será descrito como Jesus se relacionou com o poder, os enfrentamentos realizados contra as estruturas institucionais de poder da época, tanto o governo de Roma quanto o poder religioso dos judeus. A partir desses enfrentamentos e de confrontos, Seu ministério se consolida. Sua indignação e Seu senso absoluto de cumprir com a vontade de Deus fazem com que Ele se levante e profetize contra as ações de injustiça e contra a exploração do pobre, do órfão, da viúva e do estrangeiro. Fazendo uma análise sobre as origens de Jesus e Seu envolvimento com o povo, pode-se pressupor que o ministério de Jesus deve ser reproduzido por aqueles de desejam segui-Lo.

O propósito principal de Jesus é conectar todas as pessoas em torno da mensagem do reino de Deus, e, dessa forma, apresentar a salvação e o perdão dos pecados; é assim que acontece a unidade do povo em torno de tudo aquilo que 
Jesus representa.

Para uma melhor compreensão dessas questões serão estudadas as instâncias de poder na época de Jesus, levando em conta principalmente o poder religioso. A partir dessa compreensão começar-se-á a análise dos fundamentos para o ministério cristão, pois Jesus apresenta caminhos e princípios que devem ser seguidos por aqueles que são vocacionados ou por outros que tem aspirações para tal.

A figura principal no ministério cristão é o pastor, aquele que tem a tarefa de cuidar e de certa forma reproduzir os ensinamentos de Jesus. Após estudos preliminares, percebe-se como o ministério pastoral tem sido poluído por diferentes formas de ação, correndo o risco de ser descaracterizado dos ensinos bíblicos a respeito do assunto.

Visando um melhor entendimento, serão analisadas as perspectivas pastorais no ambiente da pós-modernidade, visando prevenir e apontar alguns possíveis erros que podem ser cometidos no caminho das ações pastorais. O cristianismo precisa entender as diferentes posturas da sociedade contemporânea, como conversar com a sociedade e conseguir êxito na comunicação da verdade.

Após diálogos e análises, serão pautadas as perspectivas pastorais, como ser pastor nesse ambiente, como seguir o exemplo de Jesus num contexto diferente e com necessidades iguais, como comunicar a mensagem da salvação para uma sociedade perdida e que não se dá conta de suas necessidades. Ao analisar o poder pastoral como referência para o bem da sociedade, apontando caminhos para os pastores exercerem seu ministério de acordo com os embasamentos bíblicos e teológicos a respeito do assunto, também identificar os perigos do poder pastoral que devem ser evitados, tendo em conta os ensinamentos do Mestre. Repensar o ministério cristão à luz dos ensinamentos de Jesus permitirá não ser influenciado pelas estruturas de poder que agem na sociedade pós-moderna. Tendo em conta a abrangência dessa análise, este capitulo tem por objetivo analisar conceitos teológicos a respeito do ministério cristão e apontar caminhos preventivos e adequados para comunicar as palavras de salvação e justiça para uma sociedade que sofre e precisa ser salva. 


\subsection{Alguns conceitos bíblicos sobre o poder}

Para desenvolver os conceitos bíblicos sobre o poder e as abordagens necessárias para entender os seus fundamentos a partir das escrituras é preciso fazer uma conceituação teórica a respeito do assunto. Existem algumas palavras bíblicas que ajudam a fazer uma análise e a elaborar pensamentos a respeito do assunto.

1) Dunamis ${ }^{129}$ — a expressão mais comum para “poder" encontrada no livro de Atos. Usada sete vezes significando: a) "poder em ação ou a transferência de poder de um para outro", como em Atos 1,8, 4,7, 10,38; b) sua associação à virtude, como em Atos 3,12; c) coragem, ousadia, como em Atos 6,8; d) força e poder, Atos 8,10. Esta concepção apostólica de poder acontece por transferência, de Deus para aquele que acredita.

2) Exousia $^{130}$ — A visão apostólica de poder, como atribuída em Atos ao próprio Deus (Atos 1,7), tem seu significado advindo "do direito ou liberdade de agir". Ananias e Safira usaram este poder no arbítrio de como dispensar o dinheiro sob sua guarda (Atos 5,4); Simão, o mágico, no interesse de usar o Dom de Deus (Atos 8,19 ) e está presente no arbítrio cerceado dos homens que jazem sob o poder do diabo, como em Atos 26,18. Jesus Cristo declara Sua liberdade de deixar Sua vida, pois esse poder recebera do Pai. Deu também direito aos que creem nEle de se tornarem filhos de Deus (João 1,12). Paulo fala do direito (exousia) de pedir ajuda para o sustento dos santos (II Ts. 3,9). Por último, há aqueles que levantaram suas vestes e têm direito à Árvore da vida no Apocalipse.

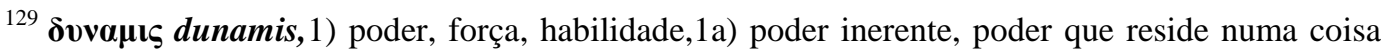
pela virtude de sua natureza, ou que uma pessoa ou coisa mostra e desenvolve,1b) poder para realizar milagres,1c) poder moral e excelência de alma,1d) poder e influência própria dos ricos e afortunados,1e) poder e riquezas que crescem pelos números,1f) poder que consiste em ou basease em exércitos, forças, multidões. STRONG, James. Léxico Hebraico, Aramaico e Grego de Strong. Versão eletrônica,. São Paulo: Sociedade Bíblica do Brasil, 2005.

${ }_{130} \boldsymbol{\varepsilon} \xi \mathbf{0 v \sigma} \boldsymbol{\alpha} \alpha$ exousia, 1) poder de escolher, liberdade de fazer como se quer, 1a) licença ou permissão, 2) poder físico e mental, 2a) habilidade ou força com a qual alguém é dotado, que ele possui ou exercita, 3) o poder da autoridade (influência) e do direito (privilégio), 4) o poder de reger ou governar (o poder de alguém de quem a vontade e as ordens devem ser obedecidas pelos outros),4a) universalmente, 4a1) autoridade sobre a humanidade, 4b) especificamente, 4b1) o poder de decisões judiciais, 4b2) da autoridade de administrar os afazeres domésticos, 4c) metonimicamente, 4c1) algo sujeito à autoridade ou regra,4c1a) jurisdição, 4c2) alguém que possui autoridade, $4 \mathrm{c} 2 \mathrm{a}$ ) governador, magistrado humano, $4 \mathrm{c} 2 \mathrm{~b}$ ) o principal e mais poderoso entre os seres criados, superior ao homem, potestades espirituais, 4d) sinal de autoridade do marido sobre sua esposa, 4d1) véu com o qual a mulher devia propriamente cobrir-se, 4e) sinal de autoridade real, coroa. STRONG, James. Léxico Hebraico, Aramaico e Grego de Strong. Versão eletrônica. São Paulo: Sociedade Bíblica do Brasil, 2005.
} 
3) $\operatorname{Kratos}^{131}$ - Concepção grega que, para o cristianismo primitivo, significava: "domínio ou principado", como no caso da posição exaltada de Cristo $($ Col.2,10). Esta palavra fala da manifestação do poder, ou da força necessária para realizar uma determinada ação (Lucas 1,51, I Pe 5,11, Jd 25). O poder (Kratos) fez com que a palavra de Deus prevalecesse poderosamente quando pregada (Atos 19,20). Quando aplicada ao crente, a palavra é usada para descrever o que Deus faz por ele (Col.1,1). Em todos os casos em que kratos é usada no Novo Testamento está objetivamente ligada ao que Deus faz e possui. A única exceção é Hebreus 2,14, que se refere ao poder de Satanás antes da cruz, agora feito nulo. Kratos refere-se, portanto, somente ao que Deus realiza, não admitindo qualquer concepção dualística de poder.

4) $\operatorname{Arch}^{132}$ - Conhecida pelos apóstolos e associada a poder e a princípio. Em Judas 6 fala-se de anjos que não "permaneceram em seu estado inicial". Portanto, Arche significa poder para guardar aquilo que inicialmente foi recebido de Deus $(\mathrm{Hb} .3,14)$.

5) Iskus - Ligada ao poder intrínseco de pessoas e coisas. Foi traduzida por “poder de Deus" em Efésios 1,19; 6,10. É a habilidade inerente àqueles que ministram em nome de Deus. (1 Pe.4,11). A noção de que o poder é algo que Deus autonomiza e separa de si, lançado para agir isolado dele, é improcedente. A.W. Tozer dizia que: "Filhos da era da máquina como somos, é difícil lembrar que não existe poder separadamente de Deus. Se o poder físico, intelectual ou espiritual está encerrado em Deus, dele flui e para ele retorna. O poder que opera em todos os âmbitos de sua criação permanece nele, mesmo quando está agindo num átomo ou numa galáxia."133

\footnotetext{
${ }^{131}$ кратоక kratos, 1) força, vigor; 2) poder: forte com grande poder; 2a) uma ação poderosa, um obra de poder; 3) domínio. STRONG, James. Léxico Hebraico, Aramaico e Grego de Strong. Versão eletrônica. São Paulo: Sociedade Bíblica do Brasil, 2005.

$\left.{ }^{132} \boldsymbol{\alpha} \boldsymbol{\rho} \chi \eta \boldsymbol{a r c h e ́}, 1\right)$ começo, origem, 2) a pessoa ou coisa que começa, a primeira pessoa ou coisa numa série, o líder, 3) aquilo pelo qual algo começa a ser, a origem, a causa ativa, 4) a extremidade de uma coisa, 4a) das extremidades de um navio, 5) o primeiro lugar, principado, reinado, magistrado, 5a) de anjos e demônios. STRONG, James. Léxico Hebraico, Aramaico e Grego de Strong Versão eletrônica. São Paulo: Sociedade Bíblica do Brasil, 2005.

${ }^{133}$ RODRIGUES, R. G. O evangelho do Poder. In: STEUERNAGEL, Valdir. No princípio era o Verbo. Evangelho, Cultura e Missão. Curitiba: Encontrão, 1994. p. 132.
} 


\subsection{O ministério de Jesus como referência ao exercício de poder}

Para conceituação e análise dessa questão será feita uma abordagem sobre a vida e o ministério de Jesus, como fundamentação teórica para o ministério cristão.

Diferente dos ministérios profissionais de sua época, Jesus não se conformou aos moldes da religião formal. Seu ministério não se encaixa dentro da estrutura padrão do primeiro século. E já começou de modo diferente: ele simplesmente chamou alguns homens para segui-lo. Nada de programas espetaculares para atrair multidões, nada de campanhas grandiosas, nem mesmo um planejamento ministerial. Ele apenas reuniu em torno de si um punhado de homens com os quais mantinha comunhão íntima, e fez deles o ponto central de todo o seu ministério ${ }^{134}$

Jesus Cristo revela a verdadeira natureza da onipotência Divina. Feita de Aniquilamento de um exercício do poder concebido essencialmente como um serviço: "Se alguém quiser ser o primeiro, seja o último de todos e o servo de todos" (Mc 9.35). Primeiro homem a viver totalmente seu poder como serviço ("Eu, porem estou no meio de vos como aquele que serve", Luc 22,27; Mc 10.45; Jo13,1-20), Jesus contesta as formas de poder que esmagam, escravizam, recusamse a reconhecer seus próprios limites (Jo 18,36) ou se servem de Deus para garantir seu próprio prestigio e sobrevivência (Mt 23,1-33). Ao manifestar mediante todas as dimensões de sua vida que não existe verdadeiro poder senão no serviço, ele se oferece como vítima ao poder dos homens e salva a humanidade da incapacidade, na qual ela se encontrava, de realizar sua vocação. Assim abre-se aos homens o acesso a um uso do poder perfeitamente de acordo com a sua vocação e com a missão que Deus lhes confiou ${ }^{135}$

Jesus é o paradigma para a reflexão bíblica a respeito do poder, com práticas contextuais e objetivas Ele consegue agir dentro da cultura e do contexto social e político de sua época. Sua convivência com as pessoas, o Seu posicionamento político de forma antagônicas ao do povo judeu, fez com que Ele reagisse e ao mesmo tempo se apresentasse como uma ameaça aos poderosos de seu tempo. De certa forma, o governo romano era aparentemente um governo de paz, conduzido por interesses políticos e egoístas. Seus governantes desejavam influenciar todo o seu território conquistado, somente o povo judeu não compactuava com suas práticas vigentes, não se submetiam às questões religiosas.

Jesus apresentou uma nova alternativa de vida no Seu ministério para o

\footnotetext{
${ }^{134}$ SWINDOLL, Charles. Firme e seus valores. Belo Horizonte: Betânia, 1985. p. 110.

${ }^{135}$ LEVY, B. H. La Barbarie à visage humain. Paris: Grasset, 1977. p.86
} 
povo que ansiava por um messias libertador. As ações de Jesus apontavam caminhos para a libertação e traziam esperança para as pessoas que estavam sofrendo, aqueles que estavam sendo explorados e doente. Entre os religiosos, existia uma casta de sumos sacerdotes ${ }^{136}$, estes compravam o cargo por dinheiro e depois procuravam fazer com que o cargo permanecesse na posse do próprio clã, essa prática ilegal era malvista e odiada pelo povo. ${ }^{137}$

Nesse mesmo tempo, Ananias que era um sacerdote de mérito, conquistava o coração de todos. Não havia quem não o honrasse pela liberdade; não se passava um dia sem que ele não desse presentes a Albino e ao sumo sacerdote. Mas ele tinha servos tão maus que iam pelas granjas com outros que não eram melhores do que eles, tomar a força as décimas, que pertenciam aos sacerdotes e batiam nos que se recusavam a dá-las. Outros faziam também a mesma coisa; assim, os sacerdotes, que não tinham outro meio de vida, achavam-se reduzidos aos extremos, sem que ninguém se resolvesse a dar um remédio a isso. ${ }^{138}$

A multidão percebia as suas aspirações sendo sufocadas pela grandeza do

Império Romano e o seu amplo domínio sobre o mundo da época. Nesse contexto, Jesus se apresenta e propõe um modelo de vida libertador, totalmente diferente dos moldes romanos, que dominavam, escravizavam e matavam aqueles que não

\footnotetext{
${ }^{136}$ Segundo Flávio Josefo: No início, o sumo sacerdócio era um cargo hereditário e vitalício, mas os asmoneus o usurparam no segundo século. Herodes, o Grande, nomeava e destituía os sumos sacerdotes, deixando claro que era ele a verdadeira autoridade. Os governadores romanos da Judeia seguiam uma prática semelhante. Esses acontecimentos levaram à formação de um grupo que as Escrituras chamam de "principais sacerdotes". (Mateus 26:3,4) Além de Caifás, esse grupo incluía ex-sumos sacerdotes, tais como Anás que havia sido deposto, mas continuava com o título. O grupo também incluía familiares imediatos dos sumos sacerdotes, tanto dos em exercício como dos antigos. Os romanos deixavam a administração diária da Judeia a cargo da aristocracia judaica, incluindo os principais sacerdotes. Isso deu a Roma o controle da província e garantiu a arrecadação de impostos, não sendo necessário enviar muitos soldados para lá. Roma esperava que a hierarquia judaica mantivesse a ordem e defendesse os interesses do império. Os governadores romanos não tinham muita afeição pelos líderes judeus, que, por sua vez, não viam o domínio romano com bons olhos. Mas a cooperação mútua visava os melhores interesses de ambos os grupos, e era para o bem de um governo estável. Na época de Caifás, o sumo sacerdote era o líder político judeu. Anás foi nomeado para esse cargo por Quirino, governador romano da Síria, Ganância, nepotismo, opressão e violência eram, segundo a tradição rabínica, características das famílias aristocráticas judaicas proeminentes. Certa escritora conclui que, como sumo sacerdote, Anás se certificaria de que seu genro fosse "rapidamente promovido para algum cargo de destaque no templo; afinal, quanto maior o cargo que Caifás ocupasse, mais útil ele seria para Anás". Valério Grato, governador da Judeia, destituiu Anás. Outros três, incluindo um dos filhos de Anás, ocuparam o cargo de sumo sacerdote numa rápida sucessão. Caifás se tornou sumo sacerdote por volta de 18 a.C. Pôncio Pilatos, que foi nomeado governador da Judeia manteve o cargo de Caifás durante todo seu mandato de dez anos. Esse período abrangeu a época do ministério de Jesus e o começo da pregação de seus discípulos. Mas Caifás era hostil para com a mensagem cristã. JOSEPHUS, Flavius. (Flavius) Josephus: With an English Translation by H. St. J. Thackeray and Ralph Marcus In 8 Volumes. In 9 Volumes. William Heinemann, GP Putnam's Son : Harvard University Press, 1965.

${ }^{137}$ GNILKA, J. Jesus de Nazaré: Mensagem e história. Petrópolis-RJ: Vozes, 2000. p. 47.

${ }^{138}$ JOSEFO, F. História dos Hebreus. Rio de Janeiro: CPAD, 2004, p. 940.
} 
concordavam com suas leis.

$\mathrm{Na}$ época de Jesus, ocuparam o cargo cinco governadores romanos. Os períodos em que eles governaram só podem ser indicados de forma aproximada: 1) Copônio 6-9,20, 2) Marcos Antibulo 9-12, 3) Ânio Rufo 12-15, 4) Valério Grato 15-26, 5) Pôncio Pilatos 26-36. Do segundo e do terceiro governadores quase não se sabe coisa alguma. Valério Grato, nos onze anos em que exerceu o cargo, instituiu quatro Sumos Sacerdotes, dos quais, com exceção do último, todos exerceram o cargo por um ano apenas. O último foi José Caifás. Valério Grato já foi nomeado por Tibério. A política deste imperador com relação aos governadores consistia em deixá-los no cargo tanto tempo quanto fosse possível.

É o que se pode ver pelo fato de que os dois últimos governadores mencionados acima haverem permanecido na Judeia por onze anos e dez anos, respectivamente. Curiosa, porém, é a razão desta política. Tibério era de opinião de que os governadores faziam como as moscas no corpo de um ferido. Depois de haverem saciado, eles se tornam mais moderados em suas extorsões. ${ }^{139}$

\begin{abstract}
Quando Jesus nasceu, provavelmente a função de sumo sacerdote em Jerusalém ainda era exercida por Simão Bem Boethos (circa 24-5 a.C.), que pertencia a uma família alexandrinense de baixa progênie sacerdotal. Sua nomeação como sumo sacerdote por Herodes o Grande lança uma luz sobre as condições políticas características da época e sobre a posição do segundo homem no estado judeu, logo após o rei. Simão tinha uma filha, chamada Marimna, que era considerada a mais bela mulher de seu tempo. Herodes, que a desejava ter por esposa, superou o obstáculo da distância social promovendo o pai ao posto de sumo sacerdote. Com o filho a que Mariamne deu à luz, e que também se chamava Herodes, já nos deparamos mais acima. Ele casou-se com Herodíades, a quem Antipas fez com que o abandonasse mais tarde, o que provocou as objeções de João Batista. Mas por fim o Sumo Sacerdote Simão caiu em desgraça junto com Herodes o Grande, por razões ligadas à conspiração de Antípater. Ele foi sem mais nem menos deposto pelo rei, e em seu lugar entrou Matias bem Theophilos, um cidadão de Jerusalém. ${ }^{140}$
\end{abstract}

Para saber alguma coisa sobre a relação de Jesus com o estado e com o poder do estado, é bom lembrar que Ele terminou sendo uma vítima desse poder. Isto não significa que Ele tivesse uma atitude de rejeição à autoridade de seu tempo. Mas, do que nos foi transmitido e que pode ser considerado como patrimônio autêntico de Jesus, não é difícil perceber certa reserva e ceticismo, que correspondem a uma reação interior, contra os modelos opressores e exploradores

\footnotetext{
${ }^{139}$ GNILKA, J. Jesus de Nazaré: Mensagem e história. Petrópolis-RJ: Vozes, 2000. p. 43.

${ }^{140}$ GNILKA, J. Jesus de Nazaré: Mensagem e história. Petrópolis-RJ: Vozes, 2000. p. 45.
} 
de governo. "Sabeis que os que parecem governar as nações as oprimem e os grandes tiranizam" (Mc 10,42).

Era uma comunidade de contrastes. O julgamento dos que dominam neste mundo é a um só tempo realista e crítico, mas não lhe falta o fundo teológico. $\mathrm{O}$ esperado domínio de Deus, que porá um fim a todo domínio terreno, e com isso também a toda opressão e a todo abuso do poder, e que já agora quer se mostrar antecipadamente na comunidade dos discípulos, onde há de vigorar uma lei diferente da lei da opressão, declara o poder político, que dura pouco, como ilusória aparência. Os potentados terrenos não são os dominadores definitivos do mundo, existe um poder maior e transcendente. ${ }^{141}$

Esta é a realidade política, sociológica e religiosa em que Jesus estava inserido. O compromisso com a mensagem do reino de Deus praticada por Ele, apesar de ser o próprio Deus feito homem, se acultura, convive com a realidade e ao mesmo tempo pratica um enfrentamento que lhe custa a vida, porque sua proposta confronta o modelo de governo reinante na época. Seu exemplo se torna forte e marcante e tem sobrevivido na história da humanidade, e se tornou uma nova opção ou alternativa para o exercício do poder.

Sua postura e sua mensagem causam tamanho impacto dentro do sistema religioso da época que Ele consegue desestruturar aqueles que faziam propostas contrárias aos ensinos do Reino de Deus. A tradição que declara que Jesus sentava-se à mesa com publicanos e pecadores e comia com eles. Este comportamento rompe a ordem até então vigente, que valorizava diferentemente as classes sociais e estabelecia divisões.

Mesmo na comunidade judeu-cristã mais tarde acontece o chamado incidente Antioqueno, quando o Apóstolo Paulo discorda abertamente da posição de Pedro sobre determinadas questões (Gl 2,11-14). E também na comunidade de Corinto ocorreram incompreensões e dificuldades nas refeições comuns (Cor.11,17-22). A comunhão na mesa também se ajusta perfeitamente ao estilo de vida de Jesus. Durante o tempo de sua vivência, Ele levava uma vida nomade, sem uma casa com residência fixa. Possivelmente dispunha da casa da família de Simão Pedro, em Cafarnaum, local de refúgio para uma permanência provisória. $^{142}$

${ }^{141}$ GNILKA, J. Jesus de Nazaré: Mensagem e história. Petrópolis-RJ: Vozes, 2000. p. 220.
${ }^{142}$ GNILKA, J. Jesus de Nazaré: Mensagem e história. Petrópolis-RJ: Vozes, 2000. p.105. 
Suas declarações éticas "nada convencionais" fazem com que vários conceitos sejam revistos e as práticas religiosas sejam questionadas e comparadas com os princípios por Ele apresentados. E na forma de um servidor, de um escravo, que está disponível para o seu próximo, segue sua jornada de vida e apresenta alternativas para libertar o povo da escravidão.

No relato do Evangelho de João isso se concretizou quando Jesus lavou os pés de seus discípulos (Jo.13,2-17). Vale a pena repetir aqui as palavras chaves:

"Se eu, que sou o Senhor e Mestre, tenho lavado vossos pés, também vocês devem lavar os pés uns dos outros. Tenho lhes dado o exemplo para que vocês façam o que lhes tenho feito. Porque em verdade lhes digo: $\mathrm{O}$ escravo não é nada mais do que o seu amo, nem o enviado maior do que aquele que o envia. Agora que vocês sabem isto, serão felizes se o põem em prática" (Jo 13,14-17). ${ }^{143}$

O conceito de poder cristão foi influenciado pela cultura secular, e não necessariamente pela revelação bíblica que passa inevitavelmente pelo calvário, onde se culminou o triunfo do amor sobre o poder. É preciso resgatar o significado do poder de que Jesus fala, a partir de uma compreensão da natureza do amor manifestado na cruz. ${ }^{144}$

O objetivo do movimento de Jesus era uma reconfiguração transformadora da sociedade, visionariamente definida pela metáfora do "Reino de Deus" e até mesmo a transformação do mundo todo, embora o reino de Deus não devesse ser realizado por seres humanos, mas por Deus. O ser humano era participe dessa transformação. $\mathrm{O}$ chamado ao arrependimento visava a sua renovação redentora. Cabia-lhe transformar sua conduta de vida desde os alicerces. ${ }^{145}$

No processo de anunciar a mensagem do reino de Deus (amar a Deus acima de todas as coisas e ao seu próximo como a si mesmo) e oferecer redenção da queda, Jesus pôs de cabeça para baixo os conceitos convencionais a respeito do poder. Quando os discípulos arguiram sobre quem era o maior, Jesus reprovouos, dizendo: "o maior entre vós seja como o menor; e aquele que dirige seja como o que serve" (Lc 22,26). Imagine o impacto que sua declaração causaria nas salas laterais da política ou nos escritórios atapetados dos grandes negócios - ou, em alguns dos impérios religiosos atuais. ${ }^{146}$

Nesse período, as camadas sociais apresentavam sérias diferenças entre a

\footnotetext{
143 JULIO, A. Pelas trilhas a caminho do Reino. São Paulo: Imprensa Metodista, 1998. p. 40.

${ }^{144}$ RICARDO, B. Janelas Para Vida. Curitiba: Encontrão, 1999. p.38-39.

${ }^{145}$ THEISSEN, G. O movimento de Jesus. São Paulo: Loyola, 2008, p.142.

${ }^{146}$ MICHAEL, H. Religião do Poder. São Paulo: Cultura Cristã, 1998. p. 23.
} 
população. Bem no alto encontrava-se uma pequena faixa de latifundiários, que se podia dar o luxo de morar numa casa em Jerusalém. Embaixo ficava a massa dos pequenos agricultores e diaristas. Estes últimos eram os que se achavam em pior condição. Viviam "da mão para a boca", geralmente não encontravam trabalho a não ser por um tempo limitado ou por um dia, tendo então que esperar dia após dia para encontrar alguém que os contratasse.

Ficavam nas praças e nos mercados, sem ter o que fazer, tal como é retratado na parábola dos trabalhadores na vinha, à espera do trabalho (Mt 20,116). Podiam ser contratados não apenas para a agricultura, mas também para a pesca e outros trabalhos. De Zebedeu, o pai de Tiago e João, ouvimos que ele tinha empregados para a pesca (Mc 1,20). A diária consistia por via de regra em um denário. ${ }^{147}$

Jesus atuava a favor do povo, suas propostas eram em busca de igualdade e liberdade para todos os que o seguissem. As estruturas governamentais da época privilegiavam os ricos e os descendentes das famílias tradicionais de Israel, mas para Jesus essa não é a forma de agir. Ele propõe que o rico atenda ao pobre, que o senhor assuma a posição de servo e que o pobre, o órfão, a viúva e o estrangeiro sejam atendidos em suas necessidades.

A compreensão a respeito do poder na época de Jesus passa pela religião ${ }^{148}$. Os deuses eram poderosos, também eram criadores e condutores de toda criação. Para os judeus representados por seus diversos grupos, fariseus, saduceus, escribas, essênios, Jeová, eterno, imutável, todo poderoso, não se comparava com os deuses pagãos, cultuados pelos romanos. Roma "recebe" dos gregos a mitologia e as práticas concernentes da sua religião.

O poder, longe de impedir o saber, o produz. Se foi possível constituir um

\footnotetext{
${ }^{147}$ GNILKA, J. Jesus de Nazaré: Mensagem e história. Petrópolis-RJ: Vozes, 2000. p. 64.

${ }^{148} \mathrm{O}$ termo religião traz à mente ideias diferentes para pessoas diferentes. Alguns o consideram como fé em Deus ou o ato de orar e participar de um ritual. Outros o entendem como um ato de meditação sobre algo de divino, outros ainda pensam que o termo tem a ver com atitude emocional e individual que ultrapassa esse mundo, há alguns que simplesmente identificam religião como moralidade. Segundo a conhecida etimologia do termo de Cícero, palavra latina religio deriva de religere, que significa "estar atento", refletir e observar, manter unido junto em contraste com negligere: negligenciar, enfraquecer ou seja religião quer significa cumprimento consciente do dever, reverente temor do poder superior. Lactancio o apologista tardio por volta de 260-340 d.C., pensava que o termo derivava de religare, que significa ligar, manter junto, uma relação íntima e duradoura com o divino. A religião não engloba não somente as crenças os hábitos e as tradições e os ritos que pertencem a grupos sociais específicos; inclui também as experiências individuais. LATOURELLE, R.; FISICHELLA, R; Dicionário de Teologia Fundamental. Rio de Janeiro: Vozes, 1994, p. 746-747.
} 
saber sobre o corpo, isso se deu através de um conjunto de disciplinas militares e escolares. Foi a partir de um poder sobre o corpo que se tornou possível um saber fisiológico, orgânico. O enraizamento do poder e as dificuldades que se enfrenta para se desprender dele vêm de todos esses vínculos. É por isso que a noção de repressão, à qual geralmente se reduzem os mecanismos do poder, parece muito insuficiente, e talvez até perigosa. ${ }^{149}$

Na Grécia, Homero afirmava que os reis eram "filhos de Júpiter, alimentados por Júpiter". Entre os romanos César se proclamava autor da vida e se fazia objeto de culto depois de morto. O mesmo autor considerava Cristo um produto de uma verdadeira revolução nas ideias sobre divindade dos Césares e em geral dos homens revestidos de poder, quando exclamou: "Dá ao César o que é de César, e a Deus o que é de Deus" Assim estabeleceu uma clara separação entre os reinos temporal e o reino espiritual. ${ }^{150}$

Jesus se opõe aos reinos humanos, aos impérios egoístas e comprometidos com a exploração do mais fraco e a preservação de valores meramente religiosos e institucionais. Jesus deixa bem claro com sua proposta e declarações que os princípios de Deus são antagônicos aos princípios apresentados pelo império romano. Para Jesus, o único reino totalmente legitimo é o reino de Deus, sendo Ele o seu principal protagonista e divulgador. Ao se levantar contra os reinos humanos, Jesus está se apresentando como Deus, e isto choca, mexe, desestrutura os impérios, principalmente o romano, que na época é o maior referencial de poder e esplendor humano.

A mais espetacular liderança na história da humanidade teve lugar quando o Filho de Deus se tornou o judeu galileu ${ }^{151}$ do primeiro século. Nessa identificação renunciou ao "status" e aos direitos que gozava como Filho de Deus. Dentre eles,

${ }^{149}$ GNILKA, J. Jesus de Nazaré: Mensagem e história. Petrópolis-RJ: Vozes, 2000. p. 148.

${ }^{150}$ LUCIO, M. N.. Sociologia de Poder. México: Universidade Autônoma de México Cidade Universitária, 1976. p. 21- 22.

${ }^{151}$ Jesus não passou apenas os seus primeiros anos na Galileia, ele lá viveu quase toda sua vida pública. Se adotarmos a cronologia dos evangelhos sinóticos (Mateus, Marcos e Lucas), com seu ministério de um ano, deixando-se de lado breves excursões à Fenícia (hoje Líbano) e Pereia (a atual parte norte da transjordania), ele só deixou sua província uma vez- para a fatídica jornada a Jerusalém, na Páscoa. Mas ainda que sigamos a cronologia mais longa do Quarto Evangelho de João, as temporadas judeias de Jesus correspondem às peregrinações obrigatórias ao Templo e, como tais, tiveram curta duração. Por conseguinte, para compreendê-lo, teremos que atentar para o mundo Galileu. A Galileia de Jesus, especialmente a parte onde ele atuou, a Baixa Galileia, situada ao redor do Lago Genesaré (ou Tiberíades), era um país rico, e, principalmente agrícola. Seus habitantes tinham orgulho de sua independência e eram ciosos de sua judaicidade, a qual, apesar das dúvidas frequentemente expressas pelos judenses, consideravam sem par. Eles eram também bravos e fortes. Josefo, comandante em chefe da região durante a primeira Guerra Judaica, louvalhes a coragem e os descreve como um "povo desde a infância acostumado a com a guerra" (BJ III,41). GEZA, V. Jesus e o Mundo do Judaísmo. São Paulo: Loyola, 1996. p. 14. 
Jesus abriu mão de qualquer direito à independência, tendo nascido numa manjedoura. Ele pregou dentro de um barco, comeu a última ceia num cenáculo, morreu numa cruz e foi sepultado. Em consciente renúncia, se expôs à tentação. Embora tenha se identificado completamente com os seres humanos, não perdeu a sua identidade. Permaneceu o mesmo. E assim sua encarnação ensinou-nos a respeito da identificação com os seres humanos ${ }^{152}$

A encarnação de Jesus foi providencial para resolver o problema do pecado da humanidade. Seu reino, Seu império e Sua forma de governo se evidenciam a partir dessa proposta. Jesus não estava interessado apenas em estabelecer o reino de Deus, como um império igual aos outros, mas o reino é resultado do Seu serviço. Todos aqueles que estiverem dispostos a segui-Lo irão encarnar e anunciar as mensagens concernentes a esse Reino. Jesus rompe com a pompa dos imperadores, se propõe a viver uma vida simples, de acordo com o modo de vida, do povo de sua época, um rei que não pretende ser melhor do que seus súditos, um rei que se identifica, nos pontos chaves da cultura e da sociedade.

O povo não tinha contato com o Imperador, nem com os líderes religiosos da época. Jesus conversava com o povo, curava os necessitados, dormia entre eles, comia a mesma comida, e não estava preocupado em ser reconhecido como rei, sabia que seu reino seria consequentemente estabelecido através de sua mensagem e por seus seguidores.

Através de suas práticas, Jesus confronta ${ }^{153}$ o modelo de governo e ao mesmo tempo propõe uma nova forma de liderança, ressalta a questão do poder, como uma oportunidade para servir ao próximo. Assim, o poder religioso para ser

\footnotetext{
${ }^{152}$ LEIGHTON, F. Jesus: O maior revolucionário. Rio de Janeiro: Vinde Comunicações, 1984. p.31-32.

${ }^{153} \mathrm{Na}$ distante Roma, Tibério reinava supremo. Valério Grato e Pôncio Pilatos governavam a Judeia. José Caifas era o sumo sacerdote dos judeus, presidente do Sinédrio de Jerusalém e dirigente dos saduceus. Hilel e Shamai, os líderes mais influentes das escolas farisaicas, Gamaliel, o Velho, tornou-se sucessor de Hilel. Não muito longe de Jerusalém, alguns quilômetros ao sul de Jericó, as margens do Mar Morto, os ascéticos essênios cultuavam a Deus em sagrado recolhimento e planejavam a conversão do resto do povo Judeu ao verdadeiro judaísmo, conhecido somente por eles, os seguidores do Mestre de Justiça. E, no vizinho Egito, em Alexandria, o Filósofo Filon ocupava-se de harmonizar o estilo de vida judaico com a sabedoria da Grécia sonho cultivado pelos judeus civilizados da Diáspora. Na Galileia, o tetrarca Herodes Antipas permanecia como senhor da vida e da morte, continuando a alimentar (em vão) a esperança de que um dia o imperador pusesse fim a sua humilhação, concedendo-lhe o título de rei. Ao mesmo tempo depois da revolta que se seguiu ao cadastramento de contribuintes, ou censo, ordenado em 6 d.C. pelo imperador da Síria, Públio Sulpicio Quirino, Judas, o Galileu, e seus filhos estimulavam as tendências revolucionárias dos violentos nortistas, tendências que resultaram na fundação do movimento zelote. GEZA, V. GEZA, V. Jesus e o Mundo do Judaísmo. São Paulo: Loyola, 1996. p.15-16.
} 
legítimo deve resultar no serviço, fora disso é apenas uma ferramenta para sustentar ou estabelecer as instituições humanas e religiosas.

\title{
3.3 Jesus é o modelo para o ministério cristão
}

A encarnação manifesta as características desse ser espiritual historificado. Jesus Cristo manifesta poder incomparável a) ao atrair discípulos por seu caráter e sua palavra (Mt.4,18, Mc 2,14); b) ao refutar os mais entendidos e influentes adversários que o enfrentam com argumentos e perguntas (Mt.22,26, Mc 12,34); c) ao expulsar do templo aqueles que desonravam o espaço sagrado (Mt. 21,12); d) ao operar milagres como expressão de sua compaixão pelas pessoas e como sinal que produzia fé (Mt. 11,5); e) ao expressar misericórdia e perdão aos pecadores, levando-os a uma nova dimensão de vida (Lc. 7,47); f) ao confrontar os poderes constituídos, colocando-se acima deles (Lc. 13,32); g) ao exercer autoridades sobre demônios (Lc. 5,1-20); h). Seu poder é visto também quando padece, pois, mostra que tem domínio sobre a morte. Por isso ressurge vitorioso, demonstrando que nem a morte e nem a sepultura triunfaram sobre o Filho de Deus (At. 2). ${ }^{154}$

\begin{abstract}
Jesus contesta as formas de poder que esmagam, escravizam, recusam-se a reconhecer seus próprios limites (Jo 18,36) ou se servem de Deus para garantir seu próprio prestígio e sobrevivência (Mt 23,1-33). Ao manifestar mediante todas as dimensões de sua vida que não existe verdadeiro poder senão no serviço, ele se oferece como vítima ao poder dos homens e salva a humanidade da incapacidade, na qual ela se encontrava, de realizar sua vocação. Assim abre-se aos homens o acesso a um uso do poder perfeitamente de acordo com a sua vocação e com a missão que Deus lhes confiou ${ }^{155}$
\end{abstract}

Jesus viveu em Nazaré a maior parte do tempo de sua vida. Por isso é necessário que se digam algumas palavras sobre Nazaré, de onde ele recebeu a alcunha de "O Nazareno" (Mc.1,24). No Antigo Testamento, esse lugar não é mencionado em parte alguma, como também não o é por Flávio Josefo. Isto só pode ter a ver com a pouca importância que tinha. Não obstante, Nazaré deve ter existido pelo menos na era helenística, como é demonstrado pelos túmulos na

\footnotetext{
${ }^{154}$ RODRIGUES, R. G. O evangelho do Poder. In: STEUERNAGEL, Valdir. No princípio era o Verbo. Evangelho, Cultura e Missão. Curitiba: Encontrão, 1994. p.129.

${ }^{155}$ DEBERGÉ, Pierre. Ética do Poder, Abordagem Bíblica e Teológica. São Paulo: Paulinas, 2002. p. 86.
} 
pedra encontrados na região. De acordo com as ofertas encontradas, em um destes túmulos pode ser datado de cerca de 200 a.C.

Admite-se que Nazaré foi fundada a partir de Jafa, distante apenas de trÊs quilômetros a sudoeste, uma cidade que já figura na lista das comunidades da tribo de Zabulon em Js.19,10-16. Nazaré também fica na região de Zabulon. É rodeada de colinas, ao norte fica o Nebi As'in, uma fonte ainda existente demonstra a proximidade do local com a antiga localidade. Na direção sudeste, um profundo vale leva em para uma íngreme descida ao Lago de Genesaré, situado 550 metros mais abaixo, admitindo que o lugar ficasse a cerca de 340 metros sobre o nível do mar.

Para os habitantes do lugar era difícil o caminho que os colocava em contato com o mundo, pois em direção a leste, a cerca de dez quilômetros de distância, passava a Via Maris, que ligava Damasco ao sul de Israel e ao Egito. ${ }^{156}$ Percebese na pessoa de Jesus uma participação cultural e de vivência, que conseguia inserir-se neste contexto sem passar por um conflito social e cultural.

Sob o ponto de vista da alta política romana, o tempo de vida de Jesus coincide com os governos de dois imperadores, o de Otaviano Augusto (27 a.C.14 d.C.) e o de Tibério (14-37). Nenhum dos dois esteve nestas paragens orientais do império, nenhum dos dois pisou o território da Síria ou da palestina. Porém a longa duração de seus governos garantiu paz e bem-estar ao mundo político.

Ao nome de Augusto, que o imperador obteve ao acabar com as guerras civis, e cujo prudente governo teve a sorte de ocorrer numa época feliz, está associada a lembrança da "Paxá Romana ${ }^{157}$ Augustana". Poetas e sacerdotes o aplaudiram. Virgílio, em sua quarta ácloga ${ }^{158}$, anuncia os tempos áureos.

Horácio, que compôs ocarmem saeculare, exalta Augusto em outra passagem como o maior dos monarcas. Embora não o aceitassem em Roma, o

\footnotetext{
${ }^{156}$ GNILKA, J. Jesus de Nazaré: Mensagem e história. Petrópolis-RJ: Vozes, 2000. p. 71.

157 PAX ROMANA. Lat. Paz Romana. Tb. chamada Pax Augusta, porque a ideia foi concebida pelo fundador do Império Romano, o imperador Caio Júlio César Otávio (63 a.C.-14 d.C.) chamado Augusto depois de derrotar Antônio, quando então se tornou senhor único. A pax de Augusto não tinha nada a ver com pacifismo. Baseava-se na superioridade militar de Roma. Quem a ela se subordinasse teria paz; quem a desafiasse seria esmagado. SCHULLER, A. Dicionário Enciclopédico de Teologia. Rio Grande do Sul: Concórdia, 2002. p. 359.

${ }^{158}$ Écloga é um pequeno poema pastoral que se apresenta, na maioria das vezes, em forma de um diálogo entre pastores. O termo foi inicialmente aplicado aos poemas de Virgílio e as suas obras tornaram-se conhecidas como Éclogas. As Éclogas de Virgílio foram escritas entre 42 e 37 a.C. A. T. M. Nova tradução das Éclogas de Virgílio; com notas e uma notícia da vida ao poeta. Porto: Ribeiro e Filhos, 1825.
} 
imperador permitiu que no oriente do Império venerassem-no como deus, sobretudo quando este culto fosse associado ao da deusa Roma. Um sinal bastante visível disto é o templo em Ancira (hoje Ancara), dedicado a ele, em cujos muros já no século XVI foi descoberta a extensa inscrição em latim e grego "das res gestae divi Augusti”.

Nessa relação de seus feitos, composta pelo próprio imperador, ele termina observando com especial satisfação que o senado, os nobres e todo o povo romano lhe conferiam o título de "pater patrie". Embora Augusto nunca tivesse estado na Palestina, seu poder se fazia sentir no país, representado pelo Rei Herodes e depois por seus filhos e pelo procurador romano na Judeia. ${ }^{159}$

Para governar os judeus, o governo romano incumbiu Herodes, em cujo governo ocorreu o nascimento de Jesus. Proveniente de uma rica linhagem idumeia - seu pai chamava-se Antípater, sua mãe uma nabateia chamada Cipros —, ele sempre foi visto pelo povo judeu como um intruso e um usurpador estrangeiro. Seu governo carrega o estigma das disputas com a família real dos asmoneus, que governou antes dele; disputas politicamente compreensíveis, porém sangrentas.

Também a princesa asmoneia Mariemne, sua segunda mulher, foi vítima da violência política. Ele conseguiu unificar um reino que abrangia a Indumeia, Judeia, Samaria, Galileia, Pereia e os amplos territórios ao nordeste da Palestina, e governá-los em paz por quase trinta anos. Pelo fim do ano 40 a.C., por decisão do senado romano e por iniciativa dos triúnviros Antônio e Otaviano, mais tarde Augusto, Herodes foi nomeado rei da Judeia.

Os detentores do poder romano viram nele a pessoa adequada para pacificar o insubordinado povo judeu, estabelecido nos limites do império, e submetê-lo ao poder de Roma. Seria atribuir a Herodes uma mentalidade por demais mesquinha julgar que ele agiu unicamente a partir da busca egoísta do poder. Estava, pelo contrário, convencido da vocação política de Roma, à qual procurou aderir, e sobretudo da missão ecumênica de Augusto, que depois de sua vitória sobre Marco Antônio recebeu Herodes com benevolência, embora ele tivesse sido anteriormente um partidário do seu opositor. ${ }^{160}$

Herodes, no entanto, empenhou-se por erguer sua realeza acima da instância

\footnotetext{
${ }^{159}$ GNILKA, J. Jesus de Nazaré: Mensagem e história. Petrópolis-RJ: Vozes, 2000. p. 35.

${ }^{160}$ GNILKA, J. Jesus de Nazaré: Mensagem e história. Petrópolis-RJ: Vozes, 2000. p. 36.
} 
do poder político e conferir-lhe uma aura religiosa. Fez isto, na verdade, de uma maneira que não podia deixar de parecer contraditória a todo fiel judeu e provocar-lhe a repulsa. Uma vez o rei foi ao encontro do sentimento judeu. Mandou reconstruir com renomado esplendor o templo de Jerusalém, o que aumentou o prestígio da cidade dentro e fora do país. Com isto ele edificou um reino que em sua grandeza lembrava o reino de Davi. Mas Davi era o protótipo do Messias. Por outro lado, no entanto, para Herodes, a garantia da paz, do bem-estar e da redenção não estava em Israel nem no Messias esperado, mas sim em Roma e no imperador universal, sobretudo Augusto. ${ }^{161}$

O uso do poder na época de Jesus vem acompanhado de forte ênfase religiosa. Deus e deuses determinam o modo de vida de uma nação. Quando o governante conseguia inserir este modelo no seu governo, tinha chance de ser bem-sucedido. Mas com o povo judeu essa prática não funcionava, porque seu Deus era outro, sua religião era outra, seu objetivo era servir ao Deus verdadeiro.

Jesus não estava interessado nas grandes instituições da sua época, não seguiu o modelo dos poderosos do seu tempo, pelo contrário, disse: "o grande deve servir ao necessitado". Com Sua mensagem, Jesus dirige-se ao público, e ao povo de forma geral. Mas, para Ele, apenas estar voltado para o povo não era o suficiente.

\begin{abstract}
No ano de 27-28, Jesus começou a sua atividade itinerante que leva da Galileia a Jerusalém, onde seria executado provavelmente no dia 7 de Abril do ano 30. Se trata, portanto, de uma atividade intensa porem breve, pois não chegou a durar 3 anos. Não é possível reconstruir com exatidão os lugares de suas atividades e suas rotas de viagem. Certamente se moveu nas margens do Lago da Galileia. Passava de uma aldeia para outra, porém nunca aparece visitando Seforis nem Tiberiades, as duas cidades mais importantes da Galileia. Durante algum tempo, seu centro de operações foi Cafarnaum, nas margens do Lago da Galileia. Jesus se locomovia de um lugar para outro acompanhado por um grupo de discípulos e discípulas. Sua atividade se concentrava em duas tarefas: curar enfermos de diversos males e anunciar a mensagem sobre o "reino de Deus". Sua fama cresceu rapidamente e as pessoas se mobilizavam para encontrar-se com ele. Jesus tinha o costume de retirar-se de noite a lugares separados para poder orar. ${ }^{162}$
\end{abstract}

Nos evangelhos há um grupo de pessoas que Lhe eram mais próximas. Este fato é esclarecedor e ajudar a melhor entender sua personalidade, pois demonstra que ele queria estar perto das pessoas, que não desejava percorrer seu caminho

\footnotetext{
${ }^{161}$ GNILKA, J. Jesus de Nazaré: Mensagem e história. Petrópolis-RJ: Vozes, 2000. p. 36.

162 PAGOLA, J. A. Jesus: aproximação histórica. Petrópolis: Vozes, 2011. p. 26.
} 
como um solitário. ${ }^{163}$

Sua proposta de vida e de ministério fazia contraste com as práticas autoritárias dos governantes e até dos líderes religiosos. Seu principal interesse era capacitar aquele grupo de pessoas que $\mathrm{O}$ seguia para que eles pudessem dar prosseguimento ao Seu projeto redentor da humanidade.

A questão que se levanta entre seus contemporâneos e também entre os líderes religiosos, é o fato de Jesus ser um mestre, "Rabi", "Doutor da Lei”, mas seus interesses não estão voltados somente para as questões institucionais da religião, mas em conviver com o povo, se identificar com suas dores e seus anseios, que eram muitos: a exploração do mais pobre, a cobrança exagerada de impostos, a manipulação religiosa, e a obrigação de prestar obediência absoluta para os governantes de Roma.

\begin{abstract}
Um princípio ilustra a necessidade de fazer tudo para que cada um possa exercer seu poder dentro do acolhimento das exigências e das necessidades de todos: é o princípio da subsidiariedade. Aplicado a comunidade política pelo Papa Pio XI na encíclica Quadragésimo ano (n.85), esse princípio se caracteriza pelo cuidado de se aproximar o mais possível os lugares de decisão da situação em que vivem os problemas de maneira a promover a responsabilidade de todos os cidadãos, permitindo que a cada um deles exercer verdadeiramente seu poder. Estendido a todos os domínios da vida em sociedade, ele caracteriza-se igualmente pela necessidade de um equilíbrio incessante que seja construído "entre a intervenção do Estado para regular o jogo social e a participação de cada um na sociedade, além do Estado" 164
\end{abstract}

Os evangelistas também se preocuparam em deixar registrado que Cristo entendeu que o "poder" tinha uma dimensão perigosa, e que necessitava ser redimensionado a partir dos princípios do Reino de Deus, que consistiam em amar a Deus acima de todas as coisas e ao seu próximo como a si mesmo. Já no início de seu ministério, Ele lutou contra o diabo no deserto, e Sua batalha envolvia as dimensões do poder. Na transformação das pedras em pães, foi desafiado a exercer o poder que O preservasse; e no alto da cidade sua tentação foi de cunho ideológico-espiritual: que usasse o poder para Seu próprio benefício (Mt 4,1-11). Mais tarde Jesus refutaria a atitude dos discípulos, que viam na convivência com Ele uma possibilidade de exercer poder. Jesus declarou, então, que no Seu reino o

163 RODRIGUES, R. G. O evangelho do Poder. In: STEUERNAGEL, Valdir. No princípio era o Verbo. Evangelho, Cultura e Missão. Curitiba: Encontrão, 1994. p.155.

${ }^{164}$ DEBERGÉ, Pierre. Ética do Poder, abordagem bíblica e teológica. Coleção Ética e Sociedade. São Paulo: Paulinas, 2002. p.150. 
poder não seria exercido hierarquicamente de cima para baixo, mas através do serviço (Lucas 22,24). ${ }^{165}$

Jesus não destacou na sua mensagem os temas relacionados a igreja, mas a respeito da mensagem do Reino de Deus que trazia como ênfase a libertação para o pobre, o consolo para os que choram, justiça, paz, perdão e amor para todo aquele que nEle crer. Jesus não anuncia uma ordem hierárquica estabelecida; não convoca o súdito para ser mais submisso, humilde e leal; mas propõe a libertação para viver em liberdade e para o amor, que na sua essência permite ao súdito ser súdito, mas livre, crítico e leal sem ser subserviente, é o detentor de poder servo, um servo irmão e também livre de apetência de maior poder. ${ }^{166}$

O povo pobre e sofrido era o alvo principal do ministério de Jesus, e Sua estratégia de trabalho era aplicada através do consolo, conforto e acompanhamento pessoal; ações que passam a ser uma estratégia fundamental para sua proposta. Pensando no escravo, Jesus pretendia ver a libertação do ser humano.

O modelo ministerial de Jesus tem a ver com o ser humano na sua formação integral, por isso se constrói uma mensagem a partir do cotidiano e do modo de vida de cada pessoa. No convívio com os discípulos, uma ou outra vez Jesus se preocupa em interpretar situações abstratas a seus seguidores, em uma capacitação na qual se mescla o espontâneo e o sistemático, pois Ele tinha pretensão de ensinar-lhes um modelo de vida e liberdade permanente.

Jesus aproveita os acontecimentos reais para perguntar-lhes: "Que dizeis vós outros?”. E por meio de um sistema pedagógico bem claro, os ajuda a compreender a situação. Em outros momentos, os chama: "Venham vós outros a parte" porque é necessário concentrar-se em oração e reflexão, pois o pensamento profundo era comum nos ensinamentos de Jesus. Ele delega tarefas a eles e os envia de dois a dois para proclamarem Sua palavra e a preparar o caminho para Ele. Assim, Jesus dá à tarefa pastoral uma série de princípios e de condicionantes estreitamente vinculados com sua época e com os problemas concretos que os toca enfrentar. ${ }^{167}$

\footnotetext{
${ }^{165}$ RODRIGUES, R. G. O evangelho do Poder. In: STEUERNAGEL, Valdir. No princípio era o Verbo. Evangelho, Cultura e Missão. Curitiba: Encontrão, 1994. p.130.

${ }^{166}$ BOFF, Leonardo. Igreja: Carisma e Poder. Rio de Janeiro: Vozes, 1982. p. 99.

${ }^{167}$ COSTAS, Orlando E. El Protestantismo en America Latina Hoy. Ensayos del camino. Pasadena. California: Publicaciones INDEF, 1975. p.92.
} 
Jesus exerce o papel de bom pastor. Dele se diz que cuida, protege, apascenta e dá sua vida pelas ovelhas (Jo.10). Mas por ser o enviado de Deus, sua ação pastoral também tem um caráter missionário. O Deus da Bíblia é, pois, um Deus missionário pastoral. Tem um propósito redentor na história. Vê-se a si mesmo como o grande pastor da humanidade, e vê essas ovelhas como desgarradas. Por isso envia Seu Filho em uma missão de serviço pastoral: para dar Sua vida pelas ovelhas perdidas. Pai e Filho enviam o Espírito a continuar esse trabalho, e chamam, portanto, para a comunidade de fé à missão pastoral de Deus no mundo. ${ }^{168}$

Através do seu exemplo, Jesus apresenta um modelo a ser seguido, o qual leva em conta o indivíduo em seus aspectos preponderantes e fundamentais. A procurar mais uma vez obter uma visão do conjunto que envolve o ser discípulo e o seguir a Jesus, a conclusão será que a sua característica primordial é incluir os discípulos em suas atividades cotidianas, fazê-los participar e praticar os princípios ensinados por Jesus.

Deve-se observar, no entanto, que os discípulos estão na completa dependência de Jesus, que eles não atuam em seu próprio nome, mas no nome de Jesus. Sem Ele, o anúncio da "Basileia" perde sua força. Nesta "escola" não se chegou a nenhum ensino sistemático nem a criar nenhuma tradição, mas também não se deve imaginar os discípulos como se eles percorressem as aldeias e cidades impelidos por uma ardente expectativa ou por uma pressa incansável. O tempo, de certo, era urgente, mas também era suficiente, eles não tinham a ideia de urgência e compreensão de que o tempo de Jesus era curto. ${ }^{169}$

Aprende-se no modelo ministerial de Jesus que o caráter é construído através das escolhas, e estas são fundamentais para o exercício de um "poder que não se corrompe", que não se deixa levar pela sedução de nosso tempo, nem se dedica à exploração dos outros.

Em Jesus, pois, a função do pastor não é só religiosa: tem a ver com o propósito último de Deus que, nas palavras do autor da epístola aos Efésios, é "reunir sob uma só cabeça" (anakefalaiosis) Cristo e tanto os seres celestiais como os terrestres $($ Ef.1,10). É uma função que tem dimensão cósmica, mas também histórica. Na linguagem da época, os seres “celestiais” são os poderes

\footnotetext{
${ }^{168}$ GNILKA, J. Jesus de Nazaré: Mensagem e história. Petrópolis-RJ: Vozes, 2000. p. 90.

${ }^{169}$ GNILKA, J. Jesus de Nazaré: Mensagem e história. Petrópolis-RJ: Vozes, 2000. p. 162.
} 
religiosos, do conhecimento, os políticos etc.

Jesus adotou uma conduta provocativa para sua época. Rompeu constantemente com os códigos de comportamento vigentes naquela sociedade. Não praticava as normas estabelecidas sobre a pureza ritual. Não se preocupava com o rito de limpar as mãos antes das refeições. Não praticava o jejum. Em determinadas ocasiões rompia com as normas prescritas sobre o sábado. Vivia rodeado por pessoas indesejáveis como arrecadadores de impostos e prostitutas. Vivia acompanhado de mendigos famintos e pessoas marginalizadas. De fato, confraternizava e comia com os "pecadores" e arrecadadores de impostos. Ao contrário do que era socialmente estabelecido, tratava publicamente com mulheres e as admitia entre seus discípulos. Concretamente, Maria Madalena ocupou um lugar importante no seu movimento. Ao que parece Jesus teve uma atitude especialmente acolhedora para com as crianças. Todas essas atitudes provocativas que ele adotou, resultou em reações contrárias da sociedade de sua época. Sua intenção era fazer ver a todos de maneira clara e específica que o reino de Deus está aberto para todos, sem excluir ninguém. ${ }^{170}$

O propósito de Cristo é conectar, sob Sua soberania, todas as esferas da existência: as pessoais, as sociais, as econômicas, as políticas, as culturais, assim como também as que têm a ver com a vida religiosa dos seres humanos. ${ }^{171}$

Aqueles que se propõem a seguir o ministério cristão devem seguir o modelo do Mestre, os princípios ensinados, o exemplo deixado, o trabalho árduo, a constância e a irresoluta disposição de cumprir com a vontade do Pai. Assim deve ser a atuação daqueles que se candidatam e são vocacionados para exercer o ministério cristão.

$\mathrm{Na}$ pessoa de Cristo encontram-se as respostas para dois dos maiores problemas de ego no ministério. O primeiro é o medo e o senso de inadequação “eu não sou bom ou não sou forte o suficiente para ser um líder!”. Um orgulho que pode nos fazer recuar de responsabilidades inerentes a tarefa.

Jesus não se deixa servir; ele mesmo serve a mesa (Lc 22,27). Isso não é nenhuma mistificação da humanidade. A insistência de Jesus sobre o poder como serviço e sobre o último que é o primeiro (Mc 10,42-44; 9,35; Mt 28,8-12) quer checar o relacionamento do senhor-escravo ou a estrutura de poder em termos de pura submissão cega e de privilégios. Não um poder que se basta autocraticamente a si mesmo, mas a um serviço para o bem de todos é o que Jesus quer. Uma instância menos eclesiástica que se auto afirma independentemente da comunidade dos fieis não é uma instância que pode reclamar para si a autoridade de Jesus. Jesus mesmo exercita semelhante atitude: sua argumentação nunca é fanática exigindo submissão passiva ao que diz; tenta sempre persuadir argumentar e fazer apelo ao bom senso e à razão. O que afirma não é autoritativo, mas persuasivo. Sempre leva

\footnotetext{
${ }^{170}$ PAGOLA, J. A. Jesus: aproximação histórica. Petrópolis: Vozes, 2011. p. 46.

${ }^{171}$ JULIO, A. Pelas trilhas a caminho do Reino. São Paulo: Imprensa Metodista, 1998. p. 36.
} 
em conta a liberdade do outro. Seus discípulos não são educados ao fanatismo de sua doutrina, mas ao respeito até para com os inimigos e daqueles que se lhe opõem. Nunca usa de violência para fazer vingar seus ideais. Apela e fala às consciências ${ }^{172}$

A segunda tentação opõe-se à primeira: "É a fome de poder que me leva a querer ser superior aos outros". Um orgulho que pode, de fato, fazer com que se exalte a si mesmo. $\mathrm{O}$ antídoto está na realização do que significa estar em Cristo.

O orgulho de considerar-se incapaz pode levar a uma postura independente. Com o artifício de que não se tem condições de desempenhar a vontade de Deus, nem de cumprir com os requisitos necessários para o ministério, o indivíduo se afasta e não contribui de forma significativa para a prática dos princípios ensinados por Jesus. O Mestre vai de encontro a esta atitude, apresentando uma alternativa que pode ser desempenhada por todos, e de acordo com as capacitações dadas por Deus. Para Jesus "poder" pressupõe serviço, uma dedicação do coração para ajudar ao próximo, sem interesse pessoal ou busca de "vantagens religiosas" como a salvação por obras, o reconhecimento pessoal etc.

Outra questão a ser levantada diz respeito a "sede de poder", o desejo de estar dominando, um anseio de ser reconhecido, a vontade de "brilhar" mais do que Jesus, uma busca pelo controle das pessoas e circunstâncias, um anseio pelo conhecimento com vistas a ser superior aos outros.

Essas práticas são confrontadas por Jesus. Ele não está interessado em ser conhecido, Seu desejo é cumprir com a vontade do Pai, tudo se realiza quando se está servindo ao próximo e cumprindo com o plano de Deus para com sua vida.

Se o ministério cristão é para ser modelado pela missão de Cristo, certamente implicará em fazer o que Ele fez e assim como Ele fez, deve-se participar do modo de vida das pessoas. Em se tratando de evangelização isso significa entrar no mundo dos seus pensamentos, no mundo da sua tragédia e solidão a fim de compartilhar Cristo.

Para ficar parecido verdadeiramente com o Mestre é necessário assumir o mandamento do amor, que Ele quis chamar seu e novo: "Amem-se uns aos outros, como eu os amei" (Jo 15,12). Este amor, com a medida de Jesus, com total dom de si, além de ser o diferencial de cada cristão, não pode deixar de ser a característica de sua Igreja, cujo testemunho de caridade será o primeiro anúncio, "todos reconhecerão que sois meus discípulos" (Jo 13,35). No seguimento de Jesus Cristo, praticamos as bem-aventuranças do Reino, o estilo de vida do próprio Jesus: seu

\footnotetext{
${ }^{172}$ BOFF, Leonardo. Paixão de Cristo Paixão do Mundo. Petrópolis: Vozes, 1978. p. 31.
} 
amor e obediência ao Pai, sua compaixão frente à dor humana, sua proximidade aos pobres e aos pequenos, sua fidelidade à missão seu amor até a doação de sua vida. Hoje, contemplamos a Jesus Cristo tal como os Evangelhos nos transmitiram para conhecer o que Ele fez e para discernir o que nós devemos fazer nas atuais circunstâncias ${ }^{173}$

Socialmente falando, isso significa ter a disposição para renunciar ao conforto e à segurança d a fim de doar-se em serviço aos indivíduos de outras culturas, cujas necessidades também sejam desconhecidas. Essa é uma missão encarnada, seja ela evangelística ou social ou mesmo ambas, exige uma custosa identificação com as pessoas em sua real situação. ${ }^{174}$

$\mathrm{Na}$ América Latina temos muitas respostas teológicas experimentais a essa responsabilidade. Há numerosas agências cristãs de serviço social que estão tratando, de uma ou outra forma, de ministrar as necessidades do povo latinoamericano. Sem dúvida, faz falta uma reflexão crítica pastoral sobre o significado dessa ação no contexto socioeconômico, político e cultural da América Latina. Uma reflexão que analise o papel que compete desempenhar a comunidade de fé nessa situação. Uma reflexão que absorva profundamente, examinando os problemas pessoais e estruturais das pessoas, as famílias, as comunidades, cidades e países a quem servem as referidas agências, assim como os problemas profundos da existência (vida, culpa, morte, etc.). Uma reflexão que levante a pergunta de como introduzir o evangelho feito carne em sua situação socioeconômica e cultural, ao nível de sua vida íntima e pessoal ${ }^{175}$.

$\mathrm{Na}$ sociedade atual é preciso colocar em prática alguns dos princípios ensinados por Jesus para poder superar as pressões e os modelos de ministérios que existem atualmente. Cavalcanti ${ }^{176}$ diz que "precisamos ter a mente de Cristo; sua forma de pensar, sua percepção para entender a existência humana, sua maneira de ver as coisas, prestar atenção aos seus ensinamentos, meditar nas suas palavras, aplicar seus ensinamentos com a experiência diária”. A mente de Cristo é desafiada a cada dia, pela mente deste século por ideologias contrárias aos princípios cristãos.

É preciso haver um programa sério de leitura da bíblia para conhecer os ensinos de Jesus e identificar-se ao máximo com sua maneira de pensar e de perceber o mundo. Jesus olha para o mundo com um olhar redentor, pensando no

\footnotetext{
${ }^{173}$ CELAM. Documento de Aparecida. Brasília: CNBB, 2007.

${ }^{174}$ JOHN, S. O Cristão em uma sociedade não cristã. RJ: Vinde Comunicações, 1989. p. 41.

${ }^{175}$ COSTA, Orlando E. Evangelizacíon contextual, fundamentos teológicos e pastorais. San José: Sebila, 1986. p. 89.

${ }^{176}$ CAVALCANTI, R. A Igreja, o país e o mundo; desafios a uma fé engajada Viçosa (MG):
} Ultimato. Revista Reflexão, 2000. p. 269. 
que se pode fazer para resolver os problemas da humanidade. O ser humano, por sua vez, tem se relacionado com o seu próximo pensando em como fazer para ser superior e tirar algum tipo de vantagem da situação. Não está interessado em ajudar e incentivar as pessoas a ter uma melhor qualidade de vida, nem incentivo algum para seguir os caminhos do Senhor.

Outro fator preponderante é o caráter de Cristo, cujo modelo, sua justiça, dedicação, seu posicionamento a favor do pobre, das crianças e daqueles que sofrem deve ser referência para os seus adeptos. Ao seguir o exemplo de Cristo a sociedade poderá ser melhor, as pessoas serão melhores, as boas ações serão transmitidas através das escolhas e dedicação das pessoas que servem a Jesus

$\mathrm{Na}$ pessoa de Jesus percebe-se exemplos de honestidade, faz parte da vida de Jesus o interesse genuíno por seu próximo, Seus motivos não são fabricados nem incentivados pelos instrumentos de comunicação. Ser honesto para com os outros é um desafio para o cidadão atual. Os seguidores de Jesus precisam se relacionar com seu próximo, visando ajudá-lo sem nenhum interesse escuso, seus motivos devem ser genuínos e sinceros. A misericórdia e a compaixão devem fazer parte da vida daqueles que se identificam com Jesus.

Pode-se observar ainda o temperamento de Cristo; sua maturidade emocional, sua bondade, sua humildade e mansidão, o domínio próprio precisam ser imitados, como também a forma como Ele pratica o amor. O temperamento de Cristo é desafiado a cada dia quando as doenças emocionais se tornam o assunto em questão. Jesus representa um modelo aos agressivos e aos desequilibrados, aos orgulhosos e aos vaidosos, aos promotores de dissensões, aos impiedosos, aos sectários e aos cultivadores da falsa moral e da falsa superioridade espiritual. Encontrar equilíbrio emocional nesta situação de pressão do mundo moderno torna-se um valor de referência para o cristão.

Assim como Ele foi enviado pelo Pai, também envia aqueles que nEle creem. Jesus foi encarnado, humano, ser social, aculturado, solidário, vivenciou os valores do reino de Deus (justiça e paz) na história, tomando partido ao lado da verdade e dos "pequeninos" (o órfão, o estrangeiro, o enfermo, o encarcerado, o pobre e a viúva) e esses critérios serão usados no julgamento no dia final.

A atitude de Cristo é desafiada, cada dia, pela incoerência, pela tibieza, pela contradição, pela sede pelo poder, pela falsidade, pelo egoísmo, pelo silêncio omisso das pessoas diante das injustiças, pela busca dos interesses egoístas 
daqueles que se dizem seguidores de Cristo. Os cristãos não podem pactuar com este sistema egoísta, em que prevalece o prazer e os interesses tanto pessoais quanto institucionais; é preciso romper com esse modelo e fazer a diferença.

Além disso, o cristão é desafiado a continuar a missão de Cristo: anunciar as boas novas, proclamar todo conselho de Deus, promover a comunhão e curar os enfermos do corpo, da mente e da alma, o expulsar dos demônios etc. Essa missão ampla, abrangente, integral é desafiada a cada dia pela parcialização, pelo unilateralismo, pelo esquecimento, pelos exageros, pelos desvios e desobediências de seu povo.

Parte da realidade extraordinária da fé cristã o ato que começa não simplesmente com a encarnação do Filho de Deus, mas com sua vinda com Jesus de Nazaré. Deus envia seu filho como uma pessoa de carne e osso para comunicar seu amor ao mundo. Como um fiel evangelista, Jesus se situa culturalmente, condicionado pelo tempo e espaço. Não leva a cabo sua missão evangelizadora em primeira instância como o todo poderoso Filho de Deus, mas como pessoa enviada por Deus num momento particular da história e numa situação cultural específica. Identifica-se com um povo concreto, fala sua língua e vê a realidade desde sua situação sociocultural. ${ }^{177}$

O modelo de Jesus precisa ser reproduzido, não se pode deixar-se levar pelo fascínio aos modelos gerenciais de trabalho. A simplicidade na convivência e a disposição de ajudar pessoas a se encontrarem consigo mesmo, e a descobrirem seus dons pessoais e ministeriais, torna-se uma tarefa importante a ser desenvolvida no ministério cristão.

Jesus anunciou o domínio de Deus de uma maneira única e inimitável. É certo que o domínio de Deus também deve ser anunciado junto com a mensagem da salvação, e depois ajudar as pessoas a seguirem esse caminho. E os que $\mathrm{O}$ aceitarem devem fazê-lo assim como Ele fez. Estes, porém, só conseguem fazê-lo a mandato dEle e em Seu nome, participando daquilo que Ele fez.

Com simplicidade, Jesus reage contra as estruturas de poder, pela convivência com seus seguidores, acompanhando o dia a dia das pessoas, discipulando aqueles que estavam interessados, proclamando e praticando a mensagem proclamada por Jesus, compreendendo e exercendo a vontade do Pai, rompendo com as instituições religiosas de seu tempo, não se deixando levar pelas vaidades pessoais. Essas e outras posturas tornam-se as armas de Jesus para

${ }^{177}$ COSTAS, Orlando. Evangelizacíon contextual, fundamentos teológicos e pastorais. San José: Sebila, 1986. p. 45. 
incomodar, questionar e apresentar um novo caminho para a humanidade.

Assim deve ser o ministério cristão, o modelo já está proposto, cabe aos que exercem o serviço cristão e aqueles que postulam esse cargo a seguirem o modelo de Jesus, o formato o conteúdo e as propostas do mestre estão disponíveis para aqueles que se propuserem a praticá-las.

\subsection{O modelo de poder-serviço proposto pelo Apóstolo Paulo} (Atos 20,17-38)

O Apóstolo Paulo, de certa forma, dá continuidade aos ensinamentos de Jesus e aplica os princípios no desenvolvimento do seu ministério e no treinamento dos líderes das respectivas igrejas que foram estabelecidas por ele e seu grupo de líderes. Esta análise abordará o discurso do apóstolo Paulo para seus companheiros de ministério, esse fato ocorreu na cidade de Mileto, durante a terceira viagem missionária do apóstolo. Também será analisada a fala e o conteúdo do discurso a partir de uma perspectiva pastoral. Paulo apresenta seu exemplo e postura durante seu ministério, exorta a seus líderes para que se comportem da mesma forma e por fim, apresenta uma série de procedimentos éticos a serem reproduzidos por aqueles que seguem a Jesus e desempenham tarefas ministeriais.

Para uma melhor compreensão do assunto cabe destacar aqui no texto uma possível cronologia da vida de Paulo ${ }^{178}$.

Uma possível cronologia da vida de Paulo e de suas cartas.

36 Conversão de Paulo a caminho de Damasco.

39 Visita a Jerusalém.

40-44 Estadia na Cilicia (Ásia Menor), região natal de Paulo.

\footnotetext{
${ }^{178}$ Paulo se mostrava satisfeito em ser "judeu" (At 21,39; 22,3, Israelita (2 Co 11,22; Rm 11,1) "Hebreu nascido de hebreus" e quanto a Lei, fariseu (Fp 3,6 e At 23,6). Vivi como fariseu de conformidade com o partido mais radical de nossa religião (At 26,5 e Gal 1,14). Foi educado aos pés de Gamaliel (At 22,3) se refere a Gamaliel o velho cujo apogeu em Jerusalém se situa nos anos 20-50. Ao chamar-se "hebreu", Paulo provavelmente queria dar a entender que era um judeu de língua grega, porém que podia falar aramaico (At 21,40;26,14). Jerônimo consigna ao rumor da família de Paulo procedia de Giscala, cidade Judeia. A primeira educação de Paulo se realizaria na sua maior parte em Jerusalém: "Eu sou judeu, nascido em Tarso na Cilícia, criado nessa cidade (Jerusalém) e educado aos pés de Gamaliel" (At 22,3), isso implicaria que na realidade a língua materna de Paulo era o aramaico que sua maneira de pensar era semítica. BROWN, R., FITZMYER, J. A., MURPHY, R. E., CARM, O. Comentário Bíblico San Jerónimo. v. 3. Madrid: Ediciones Cristiandad, 1972. p. 553.
} 
40-45 Chegada e estadia em Antioquia (Síria).

46-49 Primeira viagem missionária: Antioquia, Chipre e depois ao Sul da Ásia Menor. Regresso a Antioquia.

50-52 Segunda viagem missionária: Antioquia pelo Sul da Ásia Menor, Galácia, Macedônia e Corinto (I Ts). Regresso a Antioquia.

53 O Concílio de Jerusalém.

54-58 Terceira viagem missionária: Antioquia pela Galácia, Éfeso, onde Paulo permanece por três anos é preso (Gl, Fp, 1 e 2 Co).

57 Inverno em Corinto $(\mathrm{Rm})$ e regresso a Jerusalém.

58-60 Jerusalém - Encarceramento na Cesárea Marítima.

60-61 Viagem a Roma pelo mar.

61-63 Prisioneiro em Roma (durante dois anos).

65 Morto em Roma debaixo do governo de Nero ${ }^{179}$

De Mileto, mandou a Éfeso chamar os presbíteros da igreja ${ }^{180}$. E, quando se encontraram com ele, disse-lhes: "Vós bem sabeis como foi que me conduzi entre vós em todo o tempo, desde o primeiro dia em que entrei na Ásia - servindo ao Senhor com toda a humildade, lágrimas e provações e muito trabalho para sobrevivência pessoal" (1 Co 4,11-12).

Numa determinada época, Paulo se encontrava em Corinto e teve a oportunidade de conhecer ali um casal: Áquila e Priscila, eles tinham acabado de chegar da Itália. São trabalhadores que tem um bazar de lonas. São cristãos, porque Paulo não menciona seus nomes entre aqueles que ele batizou em Corinto (1 Co 1,14). Unemse a Paulo e compartilham alojamento, trabalho e comida. Temos então a seguinte situação: durante a semana Paulo trabalha manualmente e todo o sábado falava na sinagoga, tratando de convencer aos judeus e gregos (At 18,4) Porém quando Silas e Timóteo chegam da Macedônia, Paulo poderá dedicar-se integralmente a pregação da palavra $(\text { At } 18,5)^{181}$

Recorrendo ao mapa, observa-se o itinerário que, ao contrário das demais vezes em Atos, é narrado com tanta precisão. Aqui, Lucas incorporou à sua obra

\footnotetext{
${ }^{179}$ DEBERGE, P. Ética do Poder, abordagem bíblica e teológica. Coleção Ética e Sociedade. São Paulo: Paulinas, 2002. p. 12.

${ }^{180}$ Portanto, as cidades, uma a uma, tinham seu colégio de presbíteros, que eram pastores e mestres. Ora, nem todos exerciam entre o povo o ofício de ensinar, de exortar e de corrigir, o qual Paulo impõe aos bispos; mas também, para que deixassem semente após si, empenhavam-se diligentemente em instruir aos mais jovens que se haviam alistado na sagrada milícia. A cada cidade era atribuída certa região, a qual daí recebesse seus presbíteros e fosse como que integrada ao corpo dessa igreja. Os colégios presbiteriais, cada um deles, como disse, meramente no interesse de conservar-se uma boa gestão e a paz, estavam sob a direção de um bispo, o qual aos outros de tal modo precedia em dignidade, que estivesse sujeito à assembleia dos irmãos. Se, porém, o campo que lhe estava sob o episcopado era amplo demais para que pudesse cumprir por toda parte a todos os deveres de bispo, designavam-se presbíteros para certos lugares através do próprio campo, que lhe fizessem às vezes em questões de importância menor. A esses chamavam bispos regionais, porque representavam o bispo geral através da própria província. CALVINO, João. As Institutas da Religião Cristã: Edição especial com notas para estudo e pesquisa. São Paulo: Cultura Cristã, 2008. p. 76.

${ }^{181}$ DEBERGE, Pierre. Ética do Poder, abordagem bíblica e teológica. Coleção Ética e Sociedade. São Paulo: Paulinas, 2002. p. 15.
} 
um breve trecho de seu diário de viagem. Paulo "determinou" que seus companheiros fossem de navio à frente dele para Assôs, 25 quilômetros ao sul de Trôade, recebendo-o no navio somente ali. Ele mesmo percorre o trajeto por terra. Lucas não informa a razão dessa determinação. Quantas coisas havia para refletir e orar: todo o enorme campo de trabalho, no qual havia "terminado" sua atividade (Rm 15.23), e "Jerusalém", "Roma" e "Espanha", descortinando-se diante dele de modo ameaçador e convocador ( $\mathrm{Rm} 15,22-32)$.

$\mathrm{Na}$ sequência, a viagem passa pelas ilhas da costa da Ásia Menor, por Mitilene e Quios, até os contrafortes de Trogiliom, que também são especialmente mencionados nos manuscritos ocidentais. Aqui Paulo tinha de decidir se desembarcaria e iria até Éfeso ou se seguiria viagem no mesmo navio. Mas Paulo estava, com efeito, resolvido a evitar a escala em Éfeso, para não perder tempo na Ásia.

Ele só tinha uma urgência: estar em Jerusalém ${ }^{182}$ se possível para o dia de Pentecostes. Novamente não é mencionado o motivo principal de toda a viagem: a entrega da grande coleta para a igreja de Jerusalém, que tinha necessidades financeiras. Paulo deseja estar em Jerusalém no próximo grande dia festivo, o Pentecostes, porque então poderá encontrar um número especialmente grande de membros da igreja, até mesmo das redondezas de Jerusalém.

Talvez lhe pareça mais discreto visitar a cidade hostil em meio ao alvoroço da festa. Dependemos desse tipo de conjecturas, uma vez que Lucas não fornece motivos para esse insistente desejo de Paulo. Na verdade, justamente Éfeso teria demandado uma permanência mais demorada, por causa de sua importante igreja e de seus contatos com o interior da Ásia. Portanto a viagem prossegue até Mileto.

\footnotetext{
${ }^{182}$ Retornou a Jerusalém depois de muitos anos de permanência entre as nações, tivera comunhão de mesa com gentios, pelo que era altamente "impuro" conforme os conceitos levitas. "Ele não podia ser purificado disso apenas por um banho ao pôr-do-sol do mesmo dia, mas, de acordo com Nm 19,12, o sacerdote tinha de aspergi-lo duas vezes com água da purificação, no terceiro e no sétimo dia". Tiago e os presbíteros esperam que: "Saberão todos que não é verdade o que se diz a teu respeito; e que, pelo contrário, andas também, tu mesmo, guardando a lei." A questão dos cristãos das nações não é afetada por esse gesto, ela foi decidida pelo "decreto dos apóstolos", como Tiago torna a lembrar expressamente. Portanto, Paulo não precisa se preocupar de que, obedecendo à sugestão feita por Tiago, poria em perigo a liberdade da lei de suas igrejas formadas em outras nações. Esse esclarecimento se tornava muito mais necessário em vista do fato de que os representantes dessas igrejas rodeavam a Paulo e acompanhavam todo o diálogo. Com toda a liberdade ele era capaz de ser um judeu para os judeus (1 Co 9,20). Também nesse episódio podemos afirmar como os cristãos em Cesareia: "Faça-se a vontade do Senhor!". BOOR, Werner de. Carta aos Colossenses. Comentário Esperança. Curitiba: Evangélica Esperança, 2002. p. 309.
} 
Naquele tempo Mileto ${ }^{183}$, cerca de 60 quilômetros ao sul de Éfeso, era uma cidade importante por causa de seus quatro portos. Provavelmente Paulo teve ali uma parada mais longa - talvez para trocar de navio. Até que seus emissários chegassem a Éfeso e novamente voltassem a Mileto com os presbíteros ${ }^{184}$ transcorreriam dois a três dias, mesmo sob condições favoráveis de navegação. Ainda assim, isso consumiu menos tempo para Paulo do que se retornasse outra vez pessoalmente a Éfeso. Assim sendo, “mandou a Éfeso chamar os presbíteros da igreja".

Para Paulo está claro que as igrejas precisavam de uma ordem firme, ainda que numericamente não fossem muito grandes. Não é de surpreender que ao estabelecê-las, segue o comprovado exemplo das congregações judaicas. $\mathrm{O}$ fato de chamar esses presbíteros de "supervisores" (em grego "epískopos", que formou a palavra "bispo"), como no mundo grego havia essas funções necessárias em associações e comunidades, seculares ou religiosas, os "supervisores" = “epískopoi”. O número desses presbíteros em Éfeso não é informado. Naquela época tais detalhes da ordem eclesiástica nem sequer tinham importância. Por isso o discurso de Paulo aos presbíteros também é uma palavra puramente espiritual e não entra de forma alguma nas "questões da estrutura".

Deberge apresenta alguns ensinamentos de Paulo a respeito do cristão e as autoridades. Primeiro: Paulo recorda que os cristãos vivem nesse mundo e que,

${ }^{183}$ Mileto era a cidade mais distante ao sul, de todas as grandes cidades iônicas (gregas) da costa da Ásia Menor. Pertencia à região de Caria, que agora fazia parte da província romana da Ásia. A cidade ficava num promontório que se projetava da praia sul do golfo de Latmian, que formava o estuário do rio Meânder. Nos tempos romanos Mileto ainda era cidade de alguma importância, embora Éfeso a houvesse eclipsado havia muito tempo tanto comercial como politicamente. Sabese que Mileto havia abrigado uma comunidade judaica; todavia, não sabemos se Paulo pregou nela, ou se a igreja foi estabelecida ali durante os anos de sua estada na Ásia. WILLIAMS, David J. Novo comentário bíblico contemporâneo - Atos. São Paulo: Vida, 1998. p. 214

${ }^{184}$ At 11,10. Paulo e Barnabé ordenaram esses presbiterios nas igrejas que organizaram durante a sua primeira viagem missionária, At 14,23. Evidentemente, havia presbíteros em ação em Éfeso, At 20,17, e em Filipos, Fp 1,1. As epístolas pastorais repetidamente fazem menção deles, $1 \mathrm{Tm}$ 3,1.2; Tt 1,5.7. Merece atenção o fato de sempre serem mencionados no plural, 1 Co 12,28; $1 \mathrm{Tm}$ 5,17; Hb 13,7, 17. 24; 1 Pe 5,1. Os presbíteros são escolhidos pelo povo como homens especialmente qualificados para governar a igreja. É evidente intenção da Escritura que o povo sempre tenha voz nas questões da seleção deles, embora não fosse assim na sinagoga judaica, At 1,21-26; 6,1-6; 14,23. Nesta última passagem, porém, a palavra cheirotoneo pode ter perdido o seu sentido original de designar estendendo a mão, e pode significar simplesmente designar. Ao mesmo tempo, é mais que evidente que o Senhor mesmo coloca estes governantes sobre o povo e os reveste da necessária autoridade, Mt 16,19; Jo 20,22.23; At 1,24.26; 20,28; 1 Co 12,28; Ef 4,11.12; Hb 13,17. A eleição feita pelo povo é apenas uma confirmação externa da vocação interna feita pelo Senhor. Além disso, os presbíteros, embora representantes do povo, não derivam sua autoridade do povo, mas do Senhor da igreja. Eles exercem o governo sobre a casa de Deus, em nome do Rei, e são responsáveis unicamente perante Ele. BERKHOF, Louis. Teologia Sistemática. Campinas: Luz para o Caminho, 1990. p. 581. 
portanto, não podem situar-se nem por cima nem junto daqueles que exercem o poder. Posto que este seja um imperativo que regula a atitude dos discípulos de Cristo diante dos reinos, o de César e o de Deus (Mc 12,17) é preciso assumir a dupla responsabilidade do reino de César e do Reino proposto por Jesus. ${ }^{185}$

Segundo ensinamento: Paulo reconhece que as autoridades e as instituições civis não são más ou malditas. São um reflexo do Poder Divino e participam de sua obra. "Instrumento de Deus para ajudar a fazer o bem"; para compartilhar a justiça e castigar aquele que faz o mal. Portanto a cada um, e sobre cada cristão, corresponde o dever de ser um bom cidadão buscando em sua época e nas situações, as modalidades concretas de um civismo plenamente vivido e reconhecido.

Terceiro ensinamento: Paulo afirma que o exercício da autoridade deve apontar para o bem comum; e como ministro de Deus, aquele que exerce autoridade deve procurar o bem comum e se opor contra aquele que faz o mal.

Seguindo a mesma linha de raciocínio, o autor da carta a Timóteo convidará os cristãos a orar pelos reis e por todos aqueles que possuem autoridade, para que se possa gozar de uma vida tranquila, sossegada e digna (1 Tm 2,2). Portanto, a comunidade cristã não pede a conversão dos representantes do poder pagão nem o reconhecimento de um estatuto especial para a vida religiosa, mas que aqueles que possuem autoridade façam de tudo para favorecer a paz e a prosperidade.

Mais que um direito, o poder se apresenta então como um dever que obriga aqueles que o possuem a contribuir para o bem de todos, assegurando-lhes condições de vida serenas e tranquilas. Assim se consolida sua legitimidade.

Quarto ensinamento: Paulo reconhece que a submissão deve ser vivida "por convicção pessoal” (Rm 13,5). Ao contrário de uma submissão passiva, resignada ou cega, deve ser fruto de uma aceitação ou uma escolha interior que se concretiza no cumprimento dos deveres cívicos, como por exemplo, o pagamento dos impostos (Rm 13,6).

Último ensinamento: reis, imperadores, governadores ou magistrados, todos devem exercer autoridade debaixo dos olhos de Deus. Paulo afirma

\footnotetext{
${ }^{185}$ DEBERGE, Pierre. Ética do Poder, abordagem bíblica e teológica. Coleção Ética e Sociedade. São Paulo: Paulinas, 2002. p. 50-52
} 
claramente quando escreve: "não há autoridade que não venha de Deus", e que a autoridade é um "instrumento de Deus" (Rm 13,1).

Isso é bom e agradável aos olhos de Deus, pois é um sinal de que o exercício do poder não tem afrontado a capacidade de escolha de seus seguidores. Pelo contrário, é exatamente o que reflete a argumentação de Paulo, as autoridades não podem ultrapassar seus direitos, especialmente violando o princípio do bem comum, quando faz isso perderá a sua autoridade. Dessa maneira, possibilitam argumentos que não justificam seu poder e se privam, portanto do direito que os seguidores têm de obedecer. Assim as pessoas podem se levar ao direito legítimo de não obedecer.

\subsubsection{Paulo e o seu exemplo no serviço}

Lucas apresenta um exemplo - o único em sua obra - de Paulo falando diante de cristãos. Por isso não surpreende que esse discurso contenha muitas semelhanças às cartas dele. "Vós bem sabeis como foi que me conduzi entre vós em todo o tempo, desde o primeiro dia em que entrei na Ásia.” (Atos 20).

Com a chegada dos anciãos, Paulo lhes falou, de início, de seu próprio ministério. Este lhes era bem conhecido, embora ele tivesse em mente não apenas a obra em Éfeso, mas na província toda. Todavia, a maior parte de seu tempo ele passou em Éfeso, de modo que eles tinham razão especial para expressar gratidão pelo seu ministério. Daí a ênfase no grego no pronome pessoal vós, na frase "vós bem sabeis, desde o primeiro dia [...] Como em todo esse tempo me portei no meio de vós" (Atos 20). Esse apelo à memória do povo é traço familiar da fala de Paulo (Fp 1,5; 4,15; Cl 1,6; 1 Ts 2, 15), embora o verbo "saber" seja característica de Lucas.

Paulo não começa com princípios, regras ou instruções, mas com seu próprio exemplo. Foi assim que também escreveu aos Filipenses: "Irmãos, sede imitadores meus e observai os que andam segundo o modelo que tendes em nós" (Fp 3,17). Isso faz parte da essência do evangelho, em contraposição a toda a "lei": Da realidade concreta pode-se depreender como se conduz uma vida cristã. Não é o rígido cumprimento de prescrições, mas a "imitação" viva de uma vida atraente (cf. também 1 Co 11,1; Ef 5,1s) que nos leva à configuração correta de nossa própria vida. Por conseguinte, também agora na despedida Paulo não entrega aos presbíteros uma "ética cristã", mas lhes lega seu exemplo ${ }^{186}$

${ }^{186}$ WILLIAMS, David J. Novo comentário bíblico contemporâneo - Atos. São Paulo: Vida, 
Nesse legado aparece em primeiro lugar um traço fundamental: "servindo ao Senhor", um "escravo do Cristo Jesus", como ele afirma diante dos Filipenses (Fp 1,1), mas também dos Gálatas (Gl 1,10).

\begin{abstract}
"Servo de Cristo Jesus, escolhido como Apóstolo e destinado a proclamar o Evangelho de Deus" (Rm 1,1). Paulo reivindica sua autoridade sobre as comunidades que tinha fundado. Suas visitas e suas cartas o "envio" dos colaboradores demonstram que mesmo sem estar presente segue sendo a verdadeira autoridade sobre as comunidades. Qualquer questionamento sobre sua pessoa parece ser uma ofensa a genuinidade do evangelho (Gl 1,6-10). Frequentemente Paulo justifica sua autoridade por pertencer ao grupo apostólico, em virtude de sua visão e da aparição do Cristo Ressuscitado (1 Co 9,1). Outra coisa é a argumentação que ele usa em (Gl 1,15-16) onde menciona sua própria vocação profética em particular relacionadas às de Jeremias e do "servo" em Isaias. Longe de querer controlar ou dirigir tudo (2 Co 1,24). Paulo define seu ministério e de todos os pregadores do evangelho como um ministério de administração e serviço (2 Co 4,1-2). Em várias passagens de suas cartas, manifesta sua consciência de não ter outra missão a não ser obedecer pela fé (Rm 1,5; 6,16 - 17,10, 16,5.18). E para edificar o corpo de Cristo, pois Cristo tem dado seu poder para a edificação e não para destruição $(2 \text { Co } 10,8)^{187}$
\end{abstract}

Ter encontrado um "Senhor", poder viver a vida integralmente no "serviço" a esse Senhor, é isso que caracteriza a nova existência do cristão propriamente dito, bem como do "ministro" em particular. Paulo ressalta três aspectos desse "serviço": "humildade, lágrimas e provações". Qualquer "função" na igreja de Jesus estará deturpada se não for integral e resolutamente "serviço". Afinal, a "humildade" é "coragem de servir". Qualquer leitor atento das cartas de Paulo poderá constatar pessoalmente com que direito ele podia remeter à sua "humildade".

Em algumas situações da vida e do ministério do Apóstolo Paulo, podemos subestimar às vezes o sofrimento e as provas que Paulo suportou. Às vezes temos na mente um missionário seguro de si mesmo, infatigável, sempre disposto a lutar e a guerrear contra os inimigos do evangelho, um herói e imune ao menor fracasso. Porém nos deparamos com numerosas passagens em suas cartas em que Paulo faz alusão aos castigos, as penas e aos fracassos que marcaram suas numerosas missões (1 Co 4,9-11; 2 Co 4,8-10; 6,4-10; 11,22-23; 12,10; Rm 8,35-36). Como entender esta confissão na segunda carta aos Corintos: Não queremos que ignoreis, irmãos as tribulações que temos passado na província da Ásia. Vemo-nos apertados além de nossas forças, que até perdemos a esperança de continuar vivendo (2 Co 1,8-9). De fato, em diferentes aspectos a vida e o ministério do Apóstolo Paulo

1998. p. 216.

${ }^{187}$ DEBERGE, Pierre. Ética do Poder, abordagem bíblica e teológica. Coleção Ética e Sociedade. São Paulo: Paulinas, 2002. p. 20. 
estiveram marcados pelo sofrimento: fracassos, castigos e privações por causa do evangelho ${ }^{188}$

Ele vinha servindo ao Senhor com toda a humildade em um mundo onde a humildade era considerada falta, não uma virtude - era alguma coisa adequada para um escravo apenas (as palavras "toda" e "humildade" são típicas de Paulo; Ef 4,2; Fp 2,3; $\mathrm{Cl} 2,18-23 ; 3,12$ ). No entanto, Paulo via a si mesmo como um "escravo do Senhor ${ }^{189}$; quanto à expressão "ser um escravo" (Rm 12,11; 14,18; 16,18; Ef 6,7; Fp 2,22; Cl 3,24; Ts 1,9); quanto ao substantivo "servo" (Rm 1,1; Gl 1,10; Fp 1,11; Tt 1,1).

Outras passagens confirmam as atividades manuais de Paulo. Na primeira carta aos Tessalonicenses, por exemplo, Paulo recorda de suas dores e cansaços. "Recordais irmãos, nossas dores e fadigas, trabalhamos dia e noite para não ser pesados a nenhum de vós, enquanto vos anunciávamos o Evangelho de Deus (1 Ts 2,9)" "Conheceis perfeitamente o exemplo que vos temos dado, porque não temos vivido ociosamente entre vós nem temos comido o pão de ninguém; pelo contrário temos trabalhado com esforço e fadiga dia e noite para não ser pesado a nenhum de vós" $(2 \text { Ts } 3,7-8)^{190}$

Paulo se identifica com Jesus, quando expressa compaixão e sentimentos em várias situações. Em diversas situações Jesus demonstra compaixão, extasia-Se com a fé de um pagão (Lc 7,9) e com a sabedoria de um escriba (Mc 12,34). Admira-Se da incredulidade de seus compatriotas de Nazaré (Mc 6,6). Ao assistir o enterro do filho único de uma viúva, sentiu-Se comovido e "tomado de grande compaixão" aproxima-se dela e a consola dizendo: "Não chores" (Lc 7,13). Sente compaixão pelo povo faminto, errando como uma ovelha sem pastor (Mc 6,34). Quando Jesus chora a morte do amigo todos comentam: "Vede como ele o amava" (Jo 11,23)! "Aristóteles dizia que entre divindade e o ser humano, por

${ }^{188}$ DEBERGE, Pierre. Ética do Poder, abordagem bíblica e teológica. Coleção Ética e Sociedade. São Paulo: Paulinas, 2002. p. 15.

189 "Se agradasse ainda a homens, não seria servo de Cristo". Era evidente que não se negava que Paulo estivesse a serviço de Cristo. A tática transcorria de modo diferente. De forma condescendente, permitia-se que ele fosse aceito como servidor de Cristo. Enfim, as igrejas na Galácia tinham surgido por meio dele. Contudo, alegava-se que seu serviço fora apenas uma etapa preparatória. É a isso que Paulo alude. Se o reconhecem como um escravo de Jesus, e se o sentido da vida de um escravo reside em agradar a seu Senhor, como é que podem reduzir sua atuação à fórmula do agrado a pessoas? Se fossem coerentes, teriam de desacreditá-lo totalmente e admitir a oposição fundamental deles próprios. Deixar aparentemente que seu serviço continue válido e, não obstante, solapá-lo - ambas as atitudes não combinam. A propaganda deles é quebradiça. POHL, Adolf. Comentário Esperança Evangelho de Marcos. Curitiba: Evangélica Esperança, 1998. p. 46.

${ }^{190}$ DEBERGE, Pierre. Ética do Poder, abordagem bíblica e teológica. Coleção Ética e Sociedade. São Paulo: Paulinas, 2002. p. 16. 
causa diferença de natureza não seria possível a amizade", Jesus demonstra que a amizade e possível quando existe um verdadeiro sentimento de compaixão. ${ }^{191}$

O apóstolo Paulo sabia que o serviço na igreja não é viável sem dores ardentes. Tinha aprendido com os ensinos de Jesus e deveria reproduzir através de sua vida e com o relacionamento com os irmãos. Em absoluto representa sempre "alegria", mas requer "lágrimas". Também disso ele fala em suas cartas, em 2 Co 2,4; Fp 3,18. E o serviço conduz para a luta e "provações", não porque exercemos o serviço com erros e mau desempenho, mais precisamente quando o realizamos com sinceridade e amor. Paulo o descreveu pessoalmente em 2 Co 6,4-10; 11,2329; 1 Ts 2,2.15. Contudo são essas "provações" que transformam pessoas firmes e aprovadas. Paulo não diz com queixas e lamentos, mas com plena aprovação aquilo que preencheu seus anos em Éfeso. Considerou-o como "exemplar".

\begin{abstract}
Depois de trinta e nove açoites, flagelos e outros sofrimentos. Paulo menciona os perigos que se expos durante suas viagens, perigos de naufrágio, de salteadores e de falsos irmãos: "Três vezes foi naufragado; passou um dia e uma noite à deriva em alto mar. As viagens tem sido incontáveis; com perigos provenientes dos salteadores, de meus próprios compatriotas de pagãos: perigos nas cidades, perigos no mar e perigos por falsos irmãos (2 Co 11,25-26). Para terminar, Paulo menciona suas condições de vida, particularmente suas privações. Em outras cartas menciona a natureza de suas "tribulações"; as noites sem dormir (2 Co 6,5) a fome, a sede, o jejum e a indigência $(\operatorname{Rm} 8,35 ; 1 \text { Co 4,11; } 2 \text { Co } 6,5)^{192}$
\end{abstract}

O ministério paulino havia sido marcado pelo autossacrifício. As muitas lágrimas não foram derramadas por causa de suas dificuldades ("provações ${ }^{193 " ~ o u}$ "tentações"), que foram, ao contrário, uma fonte de alegria, mas pelo sofrimento alheio - por causa dos irmãos "em Cristo" que enfrentavam aflições (Rm 9,2; 2 Co 2,4; Fp 3,18), e por causa das pessoas sem Cristo que viviam num mundo "sem esperança e sem Deus" (Ef 2,12).

\footnotetext{
${ }^{191}$ BOFF, Leonardo. Jesus Cristo Libertador. 10 ed. Petrópolis: Vozes, 1985. p. 65.

${ }^{192}$ DEBERGE, Pierre. Ética do Poder, abordagem bíblica e teológica. Coleção Ética e Sociedade. São Paulo: Paulinas, 2002. p. 20.

${ }^{193} \pi \boldsymbol{\pi} \iota \boldsymbol{\rho} \alpha \boldsymbol{\mu} \mu \mathrm{s}$ peirasmos, experimento, tentativa, teste, prova; tentação, prova: a tentação gerada nos gálatas pela condição física do apóstolo, já que a mesma serviu para testar o amor dos gálatas por Paulo $(\mathrm{Gl} 4,14)$; tentação da fidelidade do homem, integridade, virtude, constância; sedução ao pecado, tentação, seja originada pelos desejos ou pelas circunstâncias externas; tentação interna ao pecado da tentação pela qual o diabo procurou desviar Jesus, o Messias, de sua divina jornada; da condição das coisas, ou um estado mental, pelo qual somos seduzidos ao pecado, ou a um desvio da fé e santidade; adversidade, aflição, aborrecimento: enviado por Deus e servindo para testar ou provar o caráter, a fé, ou a santidade de alguém; Deus sendo tentado (julgado) pelos homens; rebelião contra Deus, pela qual seu poder e justiça são colocados à prova e desafiados a serem demonstrados STRONG, James. Léxico Hebraico, Aramaico e Grego de Strong. Versão eletrônica. São Paulo: Sociedade Bíblica do Brasil, 2005. S. H8679.
} 
Tribulações e dificuldades não o levaram a "omitir nada do que vos seja salutar, de vos anunciar e ensinar o evangelho de Deus". Paulo praticou as duas modalidades de serviço que constantemente se tornam necessárias: "anunciar" a mensagem e "ensinar" em todas as questões que surgem da mensagem para a fé e a vida de cada pessoa e da comunhão. Com zelo intenso, ele aproveitou cada oportunidade para agir "publicamente e também nas casas".

Dirigiu-se "tanto a judeus como a gregos"; num comparativo com a realidade atual, seria "tanto a pessoas ligadas à igreja e afastadas como a pessoas religiosas e secularizadas". Conteúdo e alvo de sua proclamação eram simples, ainda que poderosos. Estava em jogo nada mais e nada menos que "o arrependimento para Deus e a fé em nosso Senhor Jesus".

Não havia uma instrução detalhada "sobre" Deus, mas a ação pessoal decisiva de voltar-se para Deus, "deixando os ídolos" (1 Ts 1,9), libertos do “império das trevas" $(\mathrm{Cl} 1,13)$, estando de volta para o único e legítimo Senhor e Criador. E o principal novamente não é o conhecimento teológico correto de Jesus, mas a "fé" em Jesus como o "Senhor", a entrega confiante e obediente da vida a ele. Paulo também esperou e pregou esse "arrependimento para Deus" do mesmo modo como Pedro fez no dia de Pentecostes (At 2,38).

Também o judeu devoto estava "morto para Deus" (Ef 2,3), precisando "salvar-se desta geração perversa" (At 2,40). No entanto, também para o "grego" (para o afastado, a pessoa do mundo secularizado) essa salvação é viável de modo imediato e sem o desvio pela "lei". Isso significa, inicialmente para rebater os judaístas: o "grego" não precisa tornar-se "judeu" antes que possa alcançar a salvação.

Ao mesmo tempo, porém, também significa: "o ser humano de fora" não precisa tentar tornar-se "melhor" ou "mais devoto" pelo cumprimento de quaisquer mandamentos, por exercícios místicos ou ascéticos, ou pela submissão a cerimônias eclesiásticas. A libertação plena e integral encontra-se também para ele unicamente na "fé em nosso Senhor Jesus" (At 16,31).

Do passado, o olhar se dirige para a gravidade do presente. Plenamente convicto, Paulo segue seu caminho. Desconhecido é somente o fim desse caminho. Ele está “constrangido pelo Espírito".

Ao andar nesse caminho, ele se encontra sob a direção do Espírito de Deus, ao qual obedece sem questionar. Essa certeza firme e tranquila também paira 


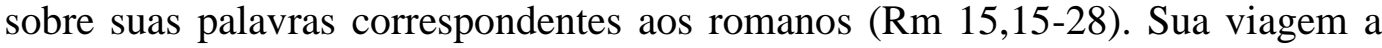
Jerusalém não representa um risco incerto e arbitrário. Ele sabe pelo Espírito Santo que precisa realizá-la.

Por essa razão tampouco constitui um abalo de sua certeza que o Espírito Santo de cidade em cidade, me assegura, que me esperam cadeias e tribulações. Estando "constrangido no Espírito", também pode tornar-se de fato constrangido com cadeias de ferro. (Atos 20,23).

A "cruz", a "morte de Jesus" nunca representou uma mera grandeza dogmática para Paulo, mas sempre um poder que configurou sua vida de forma concreta (2 Co 4,10; Fp 3,10.18). Os caminhos de Deus não são marcados por sucesso e felicidade. Novamente Paulo expõe sua vida interior como "exemplar" perante as pessoas que assumiram o serviço na igreja em Éfeso.

\subsubsection{Paulo e o oficio dos prepostos}

Nas suas ações relacionadas ao serviço cristão, Paulo reconhece a participação de seus colaboradores. Na primeira carta aos Tessalonicenses, Paulo escreve: "Decidimos enviar-vos a Timóteo, irmão nosso e colaborador de Deus na proclamação do Evangelho de Cristo. Confiamos-lhe a missão de fortalecer-vos e de alentá-los na fé" (1 Ts 3,2). Paulo não diz: "nosso" colaborador, mas sim "aquele que trabalha para Deus". Em 1 Co 3,9, Paulo inclui: "Trabalhamos unidos na obra de Deus".

O fato de que essa colaboração se situe junto a Deus, esclarece as menções nas cartas de Paulo a seus colaboradores (do grego "synergoi") fazendo menção de Silvano (1 Ts 1,1; 2 Co 1,19), Timóteo, seu "filho querido e fiel no Senhor" (1 Co 4,17; 16,10-11); Tito (2 Co 2,12-13; 7,6-7,13-15) incluindo Priscila e Áquila que ajudam a Paulo, primeiro em Corinto e depois em Éfeso (1 Co 16,19; Rm 16,3.9.21). Sem esquecer a Epafrodito, Evódia e Sintique (Fl 4,3), Filemom, Marcos, Aristarco, Dimas e Lucas (Fl 1,24).

$\mathrm{Na}$ sua lista não relaciona suas qualidades espirituais em si, mas sua atuação anterior ao lado dele e de acordo com o seu pensamento. Como tais, Paulo os recomenda à comunidade, de forma bem semelhante como fez a pouco no v. $2 \mathrm{com}$ Febe: "Ela prestou assistência a muitos, inclusive a mim pessoalmente!" Se, pois, 
ele solicita a comunidade toda com essa insistência, para que saúda esses representantes do "seu" evangelho ( $\mathrm{Rm}$ 2.16) em seu meio, o procedimento extrapola o quadro do usual e extrai do ato da saudação um sentido peculiar, a saber, seu sentido originário: anula-se uma eventual indiferença ou até um distanciamento, constrói-se a comunhão, começa a fluir a relação. Tudo isso acontece, é o que Paulo espera, por inspiração da impressão que a leitura pública de sua carta causou. Um ato de saudação com beijo fraterno deve confirmar (v. 16) que, nesse momento, os membros estão se aceitando mutuamente no sentido de Rm 14,15, assim como o próprio Deus nos aceitou em Cristo. Desde que em 1908 A. Deissmann investigou os nomes gregos, latinos e judaicos dessa lista no seu livro Licht aus dem Osten [Luz vinda do Oriente], traçam-se conclusões das formas desses nomes que, a meu ver, são demasiado avançadas. Da lista de nomes deduzse, além da origem étnica do portador, também seu testamento social (livre, escravo remediado, alforriado, relação com casas de nobres), acrescentando-lhe às vezes verdadeiros romances. Contudo, nomes gregos não tornavam alguém grego, nomes latinos não vinculavam a Roma. O próprio Paulo constitui um exemplo suficiente de que um romano-judeu da melhor estirpe era conhecido, apesar disso, por um cognome latino. Basta termos presente a facilidade com que em nossas famílias adotam nomes da moda europeus, americanos ou nórdicos ${ }^{194}$

Com reconhecimento e destaque, Paulo faz menção das penas e dos trabalhos que compartilha com esses obreiros ( $\mathrm{Rm}$ 16,3). Todos são “colaboradores de Deus" (1 Co 3,9; 16,10). E cada um receberá seu próprio "salário", segundo o seu trabalho (1 Co 3,8). Porém essa responsabilidade comum se exerce debaixo da direção e da fidelidade ao que se faz e ao que se ensina. Assim Timóteo é enviado a Corinto para lembrá-los das doutrinas que Paulo ensina "por todas as partes e em todas as igrejas" (1 Co 4,17). De igual modo, quando tem a impressão de que alguns pregadores anunciam outro evangelho, diferente do seu, Paulo não deixa de condená-los severamente (Gl 1,69; Ap 3,2; 2 Co 10-13).

Isso significa que se os companheiros e colaboradores de Paulo estão em "comunhão" esta deve ser marcada por certa "submissão". Por isso mesmo a colaboração não se considera contrária à existência e ao reconhecimento de uma autoridade, como os demais, isso não exclui a presença de uma obediência ou de uma subordinação entre os servidores.

194 POHL, Adolf. Comentário Esperança Evangelho de Marcos. Curitiba: Evangélica Esperança, 1998. p. 249. 


\subsubsection{O poder requer compromisso com a vocação}

Paulo fala: "Aliás, eu na verdade não atribuo valor algum à minha vida ${ }^{195}$. Minha meta é levar a bom termo a minha carreira e o serviço que o Senhor Jesus me confiou". Muitas vezes Paulo caracterizou a existência do cristão com a metáfora da "corrida para o alvo" (1 Co 9,24-27; Fp 3,13s; 2 Tm 4,7).

Estava profundamente preocupado em "concluir" a corrida até o alvo. Além disso, o "serviço" não era para ele um dever penoso, mas a expressão da admirável graça que seu Senhor lhe "confiou" (1 Tm 1,12s; 2 Co 4,1). Apesar de seus múltiplos aspectos, esse serviço é somente um único: "testemunhar o evangelho da graça de Deus".

A partir dessa situação, o que importa é que esse serviço confiado a ele, e do qual depende a vida eterna de muitas pessoas, seja executado. Diante da magnitude e importância desse serviço, "não atribui valor algum" ao destino pessoal. Para Paulo, a vida não tem um valor em si mesma em detrimento de seu serviço. Aqui a palavra de Jesus de Marcos 8,35 foi cumprida de forma genuína, e não como "moral cristã".

A vista disso, Paulo pode afirmar, na sequência, com toda a clareza: "Agora, eu sei que todos vós, em cujo meio passei pregando a mensagem ensinada por Jesus, não vereis mais o meu rosto." (Atos 20,25). Mais uma vez é por meio dessa forma de expressão que o caráter universal da mensagem se torna perceptível. A

\footnotetext{
${ }^{195}$ O fim da vida de Paulo termina com um breve relato do domicílio de Paulo. Sua chegada a Roma e a pregação ininterrupta do evangelho culminam com o relato que consigna a difusão da boa notícia desde Jerusalém até a capital do mundo civilizado da época: Roma simboliza o "término da terra" (At 1,8) Porém foi no final da vida de Paulo. Alusão "dois anos completos" (At 28,30) não implica que morrera imediatamente depois, a margem de como se interpreta enigmaticamente de forma final em Atos. Se as cartas pastorais (foram catalogadas no segundo século, existem várias teorias sobre as cartas, se Paulo escreveu apenas sete cartas ou se escreveu as trezes cartas, na sua maioria os documentos tendem a se fundamentar no fato de ter escrito apenas sete cartas, romanos, gálatas, primeiro e segundo coríntios, filipenses, primeiro tessalonicenses, e filemon) se consideram escritos paulinos autênticos, haveria sido composta por Paulo depois de seu domicílio em Roma. Sabendo que se aproximava o final de sua vida, Paulo constituía a Tito chefe da igreja de Creta e a Timóteo de Éfeso. Essas duas cartas haviam sido escritas para seus discípulos e suas igrejas(vale destacar que existem outros pontos de vistas a respeito das autorias das cartas paulinas). 2 Timóteo seria a última vontade de Paulo, foi escrita quando estava muito perto da sua morte. Isto sugere que pode ter sido encarcerado novamente em Troade $(2 \mathrm{Tm} 4,13)$ e levado a Roma de novo $(2 \mathrm{Tm} 1,17)$ onde essa carta haveria sido escrita desde a prisão (2 Tm 1,8.16-17; 2,9). BROWN, R., FITZMYER, J. A., MURPHY, R. E., CARM, O. Comentário Bíblico San Jerónimo. v. 3. Madrid: Ediciones Cristiandad, 1972. p. 564.
} 
igreja de Jesus não precisa esforçar-se artificialmente para construir o "caráter público" de sua atuação.

Quando fala dos ensinamentos do Mestre, ele aborda a questão mais pública que existe: aquilo que abrange toda a criação, a humanidade inteira, céus e terra, presente e futuro. Por isso a sua proclamação, conforme descrita aqui por Paulo é "pregar", anunciar como arauto. Os mensageiros de Jesus não são mestres místicos secretos, mas "arautos", que anunciam no mercado e nas ruas, da forma mais simples e audível possível, o que Deus tem a dizer a cada pessoa.

Como alguém que se despede, é importante para Paulo que ele esteja certo do dever cumprido, pois a responsabilidade repousa sobre os ombros dos mensageiros de Jesus. Ambas as coisas são simultaneamente verdadeiras: unicamente Deus desperta para a fé viva (1 Co 3,7), e apesar disso o pregador tem a tarefa de anunciar o evangelho para todos, não adianta amabilidade falsa, tentar agradar as pessoas, ficar indeciso, ser lerdo, abalar-se diante do espírito da época e outras coisas mais podem enleá-lo em culpa desse tipo. "Pois sou devedor tanto a gregos como a bárbaros, tanto a sábios como a ignorantes; por isso, quanto está em mim, estou pronto a anunciar o evangelho também a vós outros, em Roma" (Romanos 1,14).

Quando estava para completar sua tarefa naquela região, quando sabe que não pode "recuperar" nada, "consertar" nada. Quando os seres humanos que o ouviram por acaso se perderem, será culpa deles mesmos. Paulo não "deixou de anunciar" nada. Ele sabe que está "limpo do sangue de todos". Pode agora se despedir com a certeza do dever cumprido.

Paulo: "anunciou todo o desígnio de Deus" (Atos 20,27). Talvez isso tenha sido formulado enfaticamente por Paulo porque via chegar aquele movimento que mais tarde abalou profunda e especialmente as igrejas da Ásia Menor: a "gnose". Ela pretendia conhecer mistérios divinos que os pregadores teriam "deixado de anunciar" ou "ocultado".

Com essas palavras, Paulo já previa a respeito do futuro da igreja: não se iludia sobre a gravidade desse futuro. Agora, porém, não está temendo o ódio judeu, nem as aflições e perseguições por parte de um mundo hostil. Paulo estava convicto de que "havíamos de sofrer aflições" que existem para que justamente nelas a igreja confirme sua fé (1 Ts 3,3). 
No entanto, preocupa-se com a invasão dos hereges, que como lobos vorazes não pouparão o rebanho. Além do mais, prevê funestamente que das próprias fileiras dos presbíteros "se levantarão homens falando coisas pervertidas para arrastar os discípulos atrás deles”. (Atos 20,29). Assim ele já alertara os romanos quando estava em Corinto ( $\mathrm{Rm} 16,17)$. Dessa forma o serviço iria sendo sufocado pela ambição e o desejo de dominar. Os líderes que estavam se levantando na época e outros que viriam, chegariam com sede de poder e pouca disposição para servir.

Esses temores também movem o apóstolo quando pensa na igreja que está estabelecida em Éfeso ${ }^{196}$ e em toda a Ásia. Mesmo em cristãos verdadeiros o "eu" poderá retomar o comando, projetar-se com novas doutrinas e descobertas, tentando assumir um papel dominante. Em todo ser humano estão profunda e tenazmente arraigados o orgulho e a vaidade. Entre os cristão daquela época o próprio Paulo representava uma poderosa proteção por meio de sua autoridade espiritual e apostólica. Seus ensinos e doutrinas tinha a função de prevenir e orientar aos seguidores de Jesus.

Novamente Paulo pode remeter a seu próprio exemplo. "Portanto, vigiai, lembrando-vos de que, por três anos, noite e dia, não cessei de admoestar, com lágrimas, a cada um." Paulo, o fundador de igrejas, que em muitos locais levou multidões a aceitar Jesus, preocupou-se, portanto, individualmente com cada pessoa (cf. também 1 Ts 2,12). Noite e dia, incessantemente, teve tempo para cada um. Levou cada pessoa plenamente a sério, investindo nela o coração. Nesse empenho o homem duro, acostumado a sofrimentos, podia derramar lágrimas. Nele de fato vivia Cristo, o bom Pastor, que não abria a mão facilmente de uma ovelha, só porque tinha as noventa e nove outras, porém que procurava exatamente essa

${ }^{196}$ Paulo "permaneceu algum tempo na Ásia". Também em Éfeso teve de passar por uma tempestade, que lhe mostrou (e mostra a nós) que a igreja de Jesus continua ameaçada pelos poderes do mundo sobrenatural e o que está por trás deles. Isso vale mesmo quando "a palavra cresce pela força do Senhor, demonstrando o poder dele". "Foi nessa época que se deram perturbações bastante graves a respeito do Caminho". Como em Filipos, os distúrbios surgiram no ponto que o próprio Jesus já designara muito seriamente de um dos mais perigosos para nosso relacionamento com Deus: as "riquezas", o dinheiro. Em Éfeso havia o templo, mundialmente famoso, de "Ártemis", o "Artemision". O primeiro templo queimara na noite em que nasceu Alexandre Magno. Depois disso, ele fora reconstruído maior e mais suntuoso. Com suas 128 colunas de $19 \mathrm{~m}$ de altura e seus ricos ornatos artísticos, é considerado como uma das sete maravilhas mundiais da Antiguidade. Num nicho encontrava-se a imagem da deusa supostamente caída do céu, de madeira negra. Quem vinha a Éfeso - o tráfego marítimo e a grande via comercial para o leste traziam muitas pessoas para a ativa cidade - gostava de levar consigo, como "lembrança" de viagem, uma pequena réplica do templo. Foram encontradas réplicas dessas de terracota. Lucas informa que também eram confeccionadas, em grande número, de prata. Um grande setor da indústria local vivia desse comércio de lembranças, sob a direção de Demétrio. A repercussão da proclamação de Paulo é tão forte que se pode percebê-la nos negócios, e esse é um ponto muito sensível nas pessoas. BOOR, Werner de. Carta aos Colossenses. Comentário Esperança. Curitiba: Evangélica Esperança, 2002. p. 283. 
uma de modo incansável, até tê-la encontrado ${ }^{197}$

Contudo, o que aconteceria "depois de sua partida", independentemente se essa palavra se refere à sua atuação na distante Itália e Espanha ou à sua morte? Por isso, brota de seu coração a insistente advertência: "Cuidai de vós mesmos e de todo o rebanho". A despreocupação consigo mesmo é algo impróprio neste tempo e mundo. Até mesmo com vistas à nossa própria vida e obra.

Sendo "presbíteros" estão ainda mais ameaçados do que os demais. O inimigo, o verdadeiro "lobo", que se esconde atrás dos "lobos" (Jo 10,12), tem a intenção de vitimar especialmente a eles. Terá conquistado muito se fizer a natureza egocêntrica flamejar no coração de um presbítero, tirando assim muitos membros da igreja do caminho da verdade límpida!

Da mesma forma, porém, o cuidado vigilante também vale para a igreja. Ela não se desenvolve simplesmente "por si mesma" da maneira correta. Até mesmo uma conversão e um renascimento genuínos representam um começo, não um final, a entrada na arena de lutas, a largada, contudo não a chegada ao alvo e a conquista do prêmio. Por quantos perigos e ameaças também passa uma igreja de “fiéis”! É precisamente nessa situação que os presbíteros foram "constituídos supervisores". Essa eleição deu-se pelo Espírito de Deus, e não por pessoas ou instituições eclesiásticas.

No entanto, diante do grande número de atividades diárias não se reserva mais tempo nem energias para o "indivíduo". Apesar disso, a vida de toda uma igreja depende da vida dos "indivíduos". Pessoas isoladas, abandonadas à própria sorte, atolam, definham, adoecem, tornando-se assim um empecilho oculto e um foco de enfermidade espiritual para a igreja. Não é possível considerar como secundário ou supérfluo algo em que Paulo investiu sua força noite e dia nas novas igrejas vivas. Servir a cada irmão, com cuidado e proteção é uma das principais tarefas ministeriais.

Naquele tempo já era recomendado para cada presbítero o que Paulo escreve a Timóteo em 1 Tm 4,14: "Não desprezes o dom que há em ti, o qual te foi dado por profecia, com a imposição das mãos do presbitério." Sob a liderança do Espírito, Paulo e seus colaboradores agiram em At 14,23 e também nas demais

197 BOOR, Werner de. Carta aos Colossenses. Comentário Esperança. Curitiba: Editora Evangélica Esperança, 2002. p. 229. 
ocasiões em que instituíram presbíteros ${ }^{198}$ para exercerem determinadas funções ministeriais. O Concilio Vaticano II diz:

Estes pastores, escolhidos para apascentar o rebanho do Senhor, são ministros de Cristo e dispensadores dos mistérios de Deus (cfr. 1 Co 4,1); a eles foi confiado o testemunho do Evangelho da graça de Deus (cfr. Rm 15,16; At 20,24) e a administração do Espírito e da justiça em glória (cfr. 2 Co 3,8-9). Para desempenhar tão elevadas funções, no caso dos Apóstolos foram enriquecidos por Cristo com uma efusão especial do Espírito Santo que sobre eles desceu (cfr. At 1,8; 2,4; Jo 20,22-23), e eles mesmos transmitiram este dom do Espírito aos seus colaboradores pela imposição das mãos $(1 \mathrm{Tm} 4,14 ; 2 \mathrm{Tm} 1,6-7)^{199}$.

Como se torna grande a responsabilidade em vista dessa vocação; no entanto, também podem ter certeza da necessária preparação para sua tarefa, ainda que os "lobos vorazes" tentem invadir ou que no próprio grupo se levante uma heresia. O que lhes foi confiado não é nada menos que "a igreja de Deus, a qual ele comprou com o Seu próprio sangue (ou: pelo sangue de Seu próprio Filho)". Cabe aos presbíteros exercerem o cuidado do rebanho. O Concilio citado afirma:

\begin{abstract}
Desempenhando, segundo a medida da autoridade que possuem, o múnus de Cristo pastor e cabeça, reúnem a família de Deus em fraternidade animada por um mesmo espírito e, por Cristo e no Espírito Santo, conduzem-na a Deus Pai. No meio do próprio rebanho adoram-no em espírito e verdade (Jo. 4,24). Trabalham, enfim, pregando e ensinando (1 Tim 5,17), acreditando no que leem e meditam na lei do Senhor, ensinando o que creem e vivendo o que ensinam . Bispo, ao qual estão associados com ânimo fiel e generoso e cujos encargos e solicitude assumem, segundo a própria medida, e exercem com cuidado quotidiano. Em virtude da comum sagrada ordenação e missão, todos os presbíteros estão entre si ligados em íntima fraternidade, que espontânea e livremente se deve manifestar no auxílio mútuo, tanto espiritual como material, pastoral ou pessoal, em reuniões e na comunhão de vida, de trabalho e de caridade ${ }^{200}$.
\end{abstract}

Um grupo de pessoas que custou tão caro para Deus precisa ser conduzido com muita seriedade e cuidado, cabe aos presbíteros exercer suas tarefas peculiares, entre elas o serviço cristão! Paulo enfatiza: "todo" o rebanho. Também

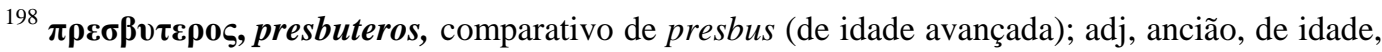
líder de dois povos, avançado na vida, ancião, sênior, antepassado, designativo de posto ou ofício, entre os judeus, membros do grande concílio ou sinédrio (porque no tempos antigos os líderes do povo, juízes, etc. eram selecionados dentre os anciãos), daqueles que em diferentes cidades gerenciavam os negócios públicos e administravam a justiça, entre os cristãos, aqueles que presidiam as assembléias (ou igrejas). O Novo Testqmento usa o termo bispo, ancião e presbítero de modo permutável, os vinte e quatro membros do Sinédrio ou corte celestial assentados em tronos ao redor do trono de Deus. STRONG, James. Léxico Hebraico, Aramaico e Grego de Strong. Versão eletrônica .São Paulo: Sociedade Bíblica do Brasil, 2005. S. H8679 .

199 CONCílio VATICANO II. Compêndio do Vaticano II: Constituições, decretos e declarações. 23a . Rio de Janeiro, Petrópolis: Vozes, 1994. p.28.

200 CONCílio VATICANO II. Compêndio do Vaticano II: Constituições, decretos e declarações. 23a. ed. Petrópolis: Vozes, 1994. p.28
} 
em suas cartas pode-se ouvir o insistente "todos... todos..." (Fp 1,1; 4,21; 1 Ts $5,27)$. Na igreja de Deus também existem vários tipos de pessoas: "desordeiros”, os "de pouco ânimo", os "fracos" (1 Ts 5,14). Existem vários filhos de Deus que não têm nada de impressionante e animador. Não obstante, fazem parte do rebanho e foram comprados por preço, é por isso todo o cuidado e amor deve ser devotado a eles.

\subsubsection{No serviço há o desgaste emocional}

O serviço cristão exige um envolvimento emocional e consequentemente acaba produzindo certos desgastes para aqueles que servem ao Senhor no ministério. Novamente Paulo volta a remeter para o seu próprio exemplo. "Portanto, vigiai, lembrando-vos de que, por três anos, noite e dia, não cessei de admoestar, com lágrimas, a cada um.” (Atos 20,31). O apóstolo Paulo, fundador de igrejas, que em muitos locais levou multidões a crerem em Jesus, preocupouse, portanto, individualmente com cada pessoa (cf. também 1 Ts 2,12). Noite e dia, incessantemente, teve tempo para cada um. Levou cada pessoa plenamente a sério, investindo nela o coração estava disposto a dar sua própria vida ${ }^{201}$. Ensina o Vaticano II:

Como todos os cristãos, devem os irmãos abraçar prontamente, com obediência cristã, todas as coisas que os sagrados pastores, representantes de Cristo, determinarem na sua qualidade de mestres e guias na Igreja, a exemplo de Cristo, o qual com a sua obediência, levada até à morte, abriu para todos o feliz caminho da liberdade dos filhos de Deus. Nem deixem de encomendar ao Senhor nas suas orações os seus prelados, já que eles olham pelas nossas almas, como devendo dar contas delas, a fim de que o façam com alegria e não gemendo $(\mathrm{Hb} 13,17) .{ }^{202}$

\footnotetext{
201 "Prontos a partilhar não apenas o evangelho de Deus, mas também nossas próprias almas". Será que a "partilha do evangelho" ainda inclui uma "prontidão" especial? Até mesmo Timóteo precisa ser advertido mais tarde por Paulo: "Anuncia a palavra, esteja presente - oportuno ou não - insta as consciências, critica, encoraja, com muita paciência e de todas as formas de instrução" ( $2 \mathrm{Tm}$ $4,2)$. Muito mais frequentes, porém, são entre nós os que por um lado são pródigos com o evangelho, mas por outro poupam a si e suas vidas. Novamente nosso serviço corre o risco de se tornar mera "profissão". O servo autêntico de Jesus doa-se integralmente, assim como seu Senhor não apenas entregou sua palavra, mas a si mesmo, por inteiro. A expressão "Nossas almas" consta no texto. É bem verdade que no NT "alma" muito frequentemente pode significar simplesmente "vida". Nesse caso a frase representaria o empenho total da vida a que os mensageiros estiveram dispostos em Tessalônica. BOOR, Werner de. Carta aos Colossenses. Comentário Esperança. Curitiba: Evangélica Esperança, 2002. p. 43.

${ }_{202}$ CONCílIO VATICANO II. Compêndio do Vaticano II: Constituições, decretos e declarações. 23ª . ed. Petrópolis: Vozes, 1994. 37.
} 
Nesse empenho, o homem duro, acostumado a sofrimentos, podia derramar lágrimas. Nele de fato vivia Cristo $^{203}$, o bom Pastor, que não abria a mão facilmente de uma ovelha, só porque tinha as noventa e nove outras, porém que procurava exatamente essa uma de modo incansável, até tê-la encontrado. Essa figura bíblica apresenta o serviço de maneira genuína, o interesse pelo rebelde, a disposição de ir procurar, encontrando ao perdido coloca no ombro e traz de volta para o rebanho. As pessoas vocacionadas por Deus têm essa sublime missão de ajudar aqueles que estão perdidos.

\begin{abstract}
"Fomos aprovados por Deus, a ponto de ele nos confiar o evangelho", é que a sorrateira busca de honra humana perde o poder sobre nós. Que nós, obreiros do Reino de Deus, paremos de considerar nosso serviço como uma obviedade a que estamos acostumados! Que compreendamos também que intensa confiança pessoal o santo e vivo Deus demonstrou ao nos chamar para seu serviço e que coisa inconcebível na verdade é ele ter "confiado o evangelho" a nós! Até nas mais escondidas profundezas de nosso coração e de nossas motivações, nosso serviço seria diferente do que frequentemente é agora! Como um fogo purificador essa consciência consumiria todo cansaço, toda indisposição e todas as motivações impuras $^{204}$
\end{abstract}

Paulo exortou e mostrou aos presbíteros a magnitude de sua responsabilidade e trabalho ${ }^{205}$. Agora, porém, ao despedir-se, ele não olha para a fidelidade e competência desses homens, mas abriga-os pessoalmente sob uma proteção diferente: "Agora, pois, encomendo-vos ao Senhor e à palavra da sua graça." (Atos 20,32). Foi assim que ele também agiu em At 14,23, nas igrejas da primeira expedição missionária. O Senhor ressuscitou, vive e atua, e a própria palavra possui em si o poder de edificar a igreja e até de levar àquele alvo final em que pecadores, antes perdidos, recebem "a herança entre todos os que são santificados". Como "filhos de Deus", afinal, também são "herdeiros", "herdeiros de Deus e coerdeiros de Cristo" $(\mathrm{Rm} 8,17)$.

\footnotetext{
${ }^{203}$ Logo já não sou eu quem vive, mas Cristo vive em mim, esse viver que tenho na carne, vivo pela fé no Filho de Deus que me amou e se entregou por mim ( $\mathrm{Gl} 2,20)$.

${ }^{204}$ BOOR, Werner de, Carta aos Colossenses. Comentário Esperança. Curitiba: Evangélica Esperança, 2002. p. 45.

${ }^{205}$ No grego "trabalhar" ocorre sempre na forma "medial", isto é, uma peculiar voz intermediária entre a ativa e a passiva. Nela existe a conotação de "trabalhar para si" ou "ganhar seu pão por meio do trabalho". Isso combina muito bem com o contexto. Não está em questão o trabalhar em si, a "virtude" da laboriosidade, mas assegurar o alimento por meio do trabalho próprio, abrir mão de se aproveitar de outros e seu amor.
} 
Paulo faz mais um retrospecto sobre sua atuação ${ }^{206}$ e ressalta o que também expôs com muita insistência aos tessalonicenses (1 Ts 2,9): "De ninguém cobicei prata, nem ouro, nem vestes; vós mesmos sabeis que estas mãos serviram para o que me era necessário a mim e aos que estavam comigo." Justamente no mundo grego, que menosprezava o trabalho corporal, Paulo levava a sério o propósito de que os membros da igreja de Jesus comessem seu próprio pão e que o amor que socorre de fato se limitasse aos "fracos".

De outra forma a maneira como Paulo concebe o exercício de sua autoridade: porque é exercida em nome do Evangelho (2 Co 4,5) e com uma finalidade para a construção e o crescimento do corpo de Cristo (1 Co 10,23-24; $12-13 ; \mathrm{Rm} 14,19)$, esta autoridade não pode se manter viva mais que a comunhão e o serviço a todos os homens, sobretudo aos mais fracos e necessitados ${ }^{207}$.

Isto aparece em numerosas passagens das cartas de Paulo, como esta exortação tão conhecida na carta aos Romanos: "Os que têm a fé bem fortalecida, devem suportar as fraquezas de quem não têm, sem buscar agradar a nós outros" ( $\operatorname{Rm} 14,1 ; 1$ Co 12,22-26; Gl 6,2). No mesmo sentido pode-se mencionar as numerosas recomendações enviadas aos dirigentes das comunidades para que renunciem aos benefícios e a dominação e se tornem em modelos para o seu rebanho (1 Tm 3,2; Tt 1,7-8). Finalmente, envia conselhos nas cartas pastorais, na sua capacidade para saber governar sua casa e seus filhos, para os bispos e diáconos é o critério para exercer suas aptidões e responsabilidades (1 Tm 3,4-5).

\footnotetext{
${ }^{206}$ Paulo conhecia a língua grega e tinha até certo ponto uma educação grega. Não chegou a ser um rhetor profissional na sua forma de expressão, revela algumas vezes a influência da retórica grega. Temos bons exemplos em Rm 2,1-20 e 1 Co 9. Muitas das antíteses literárias de Paulo têm sido atribuídas a influência grega. Houve tempo em que estava na moda atribuir aos antecedentes helenísticos de Paulo expressões tais como "Senhor", "Filho de Deus", "corpo", "carne e espírito", "mistério" BROWN, R., FITZMYER, J. A., MURPHY, R. E., CARM, O. Comentário Bíblico San Jerónimo. v. 3. Madrid: Ediciones Cristiandad, 1972. p. 763.

${ }^{207}$ Esse engajamento possuía ainda outra configuração na vida de Paulo - e naquele tempo com certeza também na de seus colaboradores: "Noite e dia labutando para não ser peso para nenhum de vós, proclamamos entre vós o evangelho de Deus. ” Em toda a sua atuação Paulo insistiu em assegurar seu sustento por meio do trabalho de suas mãos. Apenas aos Filipenses ele permitiu, excepcionalmente, que contribuíssem para seu sustento pessoal (Fp 4,15). Paulo não aceita dinheiro das igrejas, ele se sustenta com seu próprio trabalho. Mas não obstante: ao lado do trabalho integral de evangelização com extenso aconselhamento pastoral ("exortei a cada de vocês...") ele ainda fabricava tendas (ou tecia tapetes) durante longas horas. "Porque, vos recordais, irmãos, do nosso labor e fadiga" era algo que ele realmente podia afirmar, e o "noite e dia trabalhando" não era exagero! Seguramente era preciso investir muitas horas noturnas no trabalho profissional e na oração abrangente e incessante. "Vós sois testemunhas e Deus. "É de um "atestado" desses que todo obreiro do reino de Deus precisa. BOOR, Werner de. Carta aos Colossenses. Comentário Esperança. Curitiba: Evangélica Esperança, 2002. p. 47.
} 
Também nesse caso o exemplo pessoal era mais importante do que quaisquer ensinamentos e exortações. Com certeza o exemplo do dirigente da grande e trabalhosa missão, que não aceitava sustento da igreja, mas adquiria com seus companheiros o mais necessário através do trabalho manual, era poderoso. Quem ainda poderia, pois, abusar da beneficência cristã sem se envergonhar? Quando Paulo levanta as mãos - "estas mãos" - e os mostra a todos como mãos calejadas pelo trabalho. "Tenho-vos mostrado em tudo que, trabalhando assim, é mister socorrer aos necessitados." Em seguida Paulo acrescenta uma palavra do Senhor que não foi transmitida em nenhum outro texto: "Mais bem-aventurado é dar que receber." (Atos 20,35).

A presente palavra não nega que também o receber pode ser algo bemaventurado. O fraco pode aceitar auxílio com alegria, exercitando a arte de receber com gratidão. Afinal, receber é a atitude básica que todos nós temos de assumir perante Deus. Contudo, o egoísta temeroso pode constatar que "dar" não é uma obrigação que exige que nos superemos a nós mesmos, mas que é algo "bemaventurado", ainda "mais bem-aventurado que receber". Nesse aspecto podemos ser "imitadores" de nosso Deus, que é doador.

Paulo, o mensageiro de Jesus, encerrou com uma palavra do Senhor Jesus, não com sua própria palavra. Na sequência, acontece a oração com todo o grupo. O aconselhamento espiritual resulta na oração, e esse "retiro de presbíteros" é finalizado com a comunhão de oração de joelhos. Isso era um fruto visível de seu trabalho. Por fim, acontece a despedida. "Então, houve grande pranto entre todos, e, abraçando afetuosamente a Paulo, o beijavam.” (Atos 20,38).

Pessoas santificadas por Deus não se transformam em seres sobrenaturais que transitam dura e friamente pelos acontecimentos desta vida. Vivenciam tudo com um coração humano caloroso e vivo, conhecendo, por isso, as alegrias e os sofrimentos de nossa existência nesta terra não de forma limitada, mas bem mais rica e profunda. $\mathrm{O}$ fato de ser assim e de poder ser assim é evidenciado pela descrição dessa despedida. Em vista disto, é preciso ser cautelosos com um julgamento precipitado de "apego a pessoas".

Mensageiros de Jesus que levaram a outros a melhor coisa que existe hão de ser amados por eles também humanamente, como Paulo (Gl 4,13-15). É verdade, porém, que até mesmo um amor assim é sacrificado por ambas as partes em prol dAquele que por Sua incomparável ação de amor na cruz conquistou 
integralmente o direito sobre todo o nosso coração e nossa vida. Por isso, os efésios não retêm o amado apóstolo, mas "acompanharam-no até o navio".

Neste ponto Lucas, não fez uma subdivisão clara no seu livro, mas permite que a terceira viagem missionária se ligue sem maiores interrupções à última viagem para Jerusalém. O apóstolo se despede definitivamente de todo o seu campo de trabalho, um retrospecto sobre a obra missionária de Paulo. Após essa despedida, a história aponta alguns detalhes sobre o final da sua vida. ${ }^{208}$

O que, afinal, aconteceu? Será que não foram realizadas apenas viagens interessantes de um homem muito ativo, nas quais sucedeu uma série de episódios? Em 2 Coríntios 5,19-21, Paulo incluiu diretamente na obra de reconciliação de Deus. Levando em consideração o fato de que Ele "nos confiou a palavra da reconciliação”. Deus reconciliou o mundo consigo mesmo na cruz, mas a reconciliação ali consumada chega às pessoas apenas quando é anunciada por mensageiros da parte de Cristo e crida por pessoas. Ocorre que essa "palavra da reconciliação" não é um "querigma" que paira no ar, agora disponível no mundo por meio do evangelho, podendo ou não ser ouvida pelos humanos.

Pelo contrário, a proclamação dessa palavra é em si o agir do Deus vivo, que se realiza numa história bem específica, de forma plenamente real. Precisamente esse "exortar" do Deus vivo, esse "rogar" do Cristo ressuscitado, aconteceu na obra da vida de Paulo. Por essa razão ele é narrado por Lucas em At

\footnotetext{
${ }^{208}$ Quanto a outros detalhes referentes ao final da vida de Paulo, dependemos da tradição eclesiástica posterior, que se embelezou com traços lendários. Fica difícil dizer se Paulo chegou a visitar a Espanha ou se trata meramente de uma historificação de seus planos consignados em Rm 15,24-28. A tradição nos conta que Paulo, livre depois de passar dois anos preso em seu domicílio, marchou para a Espanha. Clemente de Roma (1 Co 5,7) afirma que "Paulo ensinou a todo o mundo a justiça e viajou até ao extremo ocidental. E depois que deu testemunhos diante das autoridades foi arrebatado deste mundo e chegou ao lugar santo, havendo-se acreditado como o maior modelo de perseverança". O testemunho de Clemente sugere a visita a Espanha, um novo juízo e mártir. O fragmento Muratoriano implica no fato de que a última parte de Atos, em que se narrava um novo juízo e martírio. Durante essa prisão escreveu a segunda epistola a Timóteo,(cabe destacar que existem outros pontos de vistas a respeito das autorias das cartas paulinas) indicando ao mesmo tempo em que tenha feito sua primeira defesa como mártir iminente. Porém a data preferida para a morte de Paulo é o ano 67, com aspectos finais da perseguição de Nero, como parece sugerir o relato de Eusébio. Esta cronologia, sem dúvida, não deixa de apresentar dificuldades. Paulo foi enterrado junto a Via Ostiense, nas imediações da moderna basílica de São Paulo Extramuros. O ano 258, com motivo de perigo de profanação das tumbas cristãs durante a perseguição de Valeriano, os restos de Paulo foram trasladados a um lugar chamado Ad Catacumbas, junto a Via Apia, onde permaneceram algum tempo. Mais tarde foram devolvidos a um sepultamento original sobre o qual se levantou a basílica de Constantino. BROWN, R., FITZMYER, J. A., MURPHY, R. E., CARM, O. Comentário Bíblico San Jerónimo. v. 3. Madrid: Ediciones Cristiandad, 1972. p. 564.
} 
13-20 como "história" com uma solidez impossível de inventar, tendo acontecido com pessoas bem específicas e de um modo bem determinado.

No entanto, não é uma história humana variada, em cujo decorrer aprendemos a admirar um homem de nome Paulo, mas como história ela constitui ao mesmo tempo "revelação", ação do próprio Deus vivo, no qual a salvação consumada na cruz é levada a pessoas concretas e deve se transformar em serviço.

Essa ação de Deus vale "primeiro aos judeus". Por essa razão, sempre que pode, Paulo dirige-se primeiramente às sinagogas. Isso não é um esquema narrativo de Lucas, mas algo que Paulo declarou pessoalmente em Rm 1,16. Essa ação de Deus é proclamação com um conteúdo claramente definido (cf. também 1 Co 1,23s; 2,2; Gl 3,1), e uma revelação que não possui eficácia a partir de uma qualidade retórica qualquer, mas no poder do Espírito Santo. Por isso também pode acontecer exclusivamente sob a direção do Espírito e resulta na ajuda e cuidado para com os necessitados.

A exposição de Lucas é confirmada pelas afirmações do próprio Paulo (1 Co 2,1-3; 2 Co 2,14-17). Pelo fato de que a mensagem redentora como tal já constitui uma ação maravilhosa de Deus, ela também vem quase "naturalmente" acompanhada de sinais e prodígios de múltiplas espécies. Acima de tudo, fazem parte do serviço do apóstolo as curas e a libertação de pessoas cativas, como já fizeram parte da vida de Jesus. Novamente o próprio Paulo O confirma (2 Co $12,12)$.

Da mesma forma, anunciar um Cristo que sofre e é crucificado forçosamente leva à participação nos sofrimentos de Cristo, transformando a trajetória do mensageiro num caminho de constantes dificuldades, aflições e perigos. Lucas mostrou isso de forma impactante em todas as expedições missionárias de Paulo. O próprio Paulo teve um cuidado quase ciumento, na controvérsia com os coríntios, para que esse lado de sua vocação apostólica não fosse esquecida e sempre dando destaque para a santidade. (1 Co 4,9-13; 2 Co 4,7-12; 2 Co 11,23). Afirma o Vaticano II,

A nossa fé crê que a Igreja, cujo mistério o sagrado Concílio expõe, é indefectivelmente santa. Com efeito, Cristo, Filho de Deus, que é com o Pai e o Espírito ao único Santo, amou a Igreja como esposa, entregou-Se por ela, para a santificar (Ef 5,25-26) e uniu-a a Si como Seu corpo, cumulando-a com o dom do Espírito Santo, para glória de Deus. Por isso, todos na Igreja, quer pertençam à Hierarquia quer por ela sejam pastoreados, são chamados à santidade, segundo a 
palavra do Apóstolo: «esta é a vontade de Deus, a vossa santificação» (1 Ts 4,3; Ef 1,4).Esta santidade da Igreja incessantemente se manifesta, e deve manifestar-se, nos frutos da graça que o Espírito Santo produz nos fiéis; exprime-se de muitas maneiras em cada um daqueles que, no seu estado de vida, tendem à perfeição da caridade, com edificação do próximo; aparece dum modo especial na prática dos conselhos chamados evangélicos. A prática destes conselhos, abraçada sob a moção do Espírito Santo por muitos cristãos, quer privadamente quer nas condições ou estados aprovados pela Igreja, leva e deve levar ao mundo um admirável testemunho e exemplo desta santidade ${ }^{209}$.

As pessoas salvas pela proclamação da palavra da verdade formam "a igreja", sem que tenham de ser especialmente convidadas e instruídas para isso. É na igreja que as pessoas vivem a expectativa daquele dia em que Deus plenificará sua obra na nova revelação de Jesus. Isso não exclui muitos esforços, preocupações e lutas em torno dessa igreja, como o próprio Paulo declarou aos presbíteros de Éfeso.

Na vida do apóstolo Paulo se pode ver a consolidação da Igreja de Cristo na terra, seu ardor missionário, sua atitude altruística, sua disposição sem limites de levar o evangelho para locais remotos e distantes, pagando com sua própria vida a disposição de testemunhar para quem precisava ouvir as palavras salvadoras. Através desta breve análise, avaliou-se a realidade do serviço cristão, as pessoas que foram ajudadas e salvas, as barreiras que foram vencidas pela dedicação e intensidade das ações do apóstolo e de seus companheiros de ministério.

\subsection{A relação entre a teologia e o poder}

A partir dos ensinamentos de Jesus seu referencial deixado para o ministério cristão, também o Apóstolo Paulo, sua trajetória de vida e exemplos para aqueles que postulam a graça de servir a Deus através do ministério, cabe uma análise a respeito da relação entre a teologia e o poder. Deve-se levar em conta que:"A verdade que liberta" já não é uma novidade, atualmente vive-se uma religião mercantilizada, que tem trocado o sagrado pelo financeiro. Aliás, esse não é um assunto novo, mas sem pretensão de ser repetitivo, pode-se dizer que atualmente: "vende-se a fé, por um preço módico e acessível" para todo aquele que se disponha a crer e esteja disposto a seguir as normas estabelecidas pelo mercado.

${ }^{209}$ CONCíllo VATICANO II. Compêndio do Vaticano II: Constituições, decretos e declarações. 23a . ed. Petrópolis: Vozes, 1994. 39. 
Sem generalizar, há alguns aspectos em que a religião se vendeu.

O sentido ideológico das pregações nas igrejas manifesta-se na medida em que manipulam ao seu proveito os espaços sensíveis e problemáticos dos fiéis, sobretudo no que se relaciona a saúde, a problemas financeiros e a vida sentimental das pessoas, pois, em troca de uma "pseudo" solução dos problemas, os pregadores exigem contribuições para "Jesus e a sua adesão à igreja”. Em determinadas situações tem sido apresentada uma religião manipuladora, que faz uso de ofertas misteriosas e mágicas que provém de um "deus" (ideologia do mercado) que se agrada somente dos presentes e dos compromissos inconsequentes da parte de seus seguidores, portanto para os seguidores fica a decepção pelas graças não alcançadas.

A religião tem sido um lugar de exploração e, infelizmente, vários abusos têm sido cometidos contra pessoas sinceras e tementes a Deus. Esses seguidores se submetem a determinados sujeitos manipuladores e desejosos de destaque, que usam subterfúgios absurdos para lesar a boa-fé de pessoas incultas e fascinadas pela sagrado.

Esta situação está arraigada na América Latina. Nossa América Latina foi e continua sendo um dos continentes mais convulsionados do mundo, especialmente nos últimos cinquenta anos, devido a diversos fatores, a crise física e sócio econômica de nossos povos vem se tornando mais aguda. As condições humanas vão se deteriorando mais e mais e a saúde física, social e moral de nosso povo clama por uma mudança radical que nos permita viver com dignidade e como filhos de Deus, criados à sua imagem e semelhança.

A figura de Deus tem sido abolida do espaço social e civilizatório no ambiente da pós-modernidade. Deus não mais será entendido como força sobrenatural que se exterioriza através de um domínio absoluto do destino cósmico e humano, mas como produto da própria vontade e presente na construção humana. Deixa de ser entendido como Criador Supremo de todas as coisas. Será reduzido à ideia e ao conceito de mera produção da mente humana. ${ }^{210}$

Há uma nova "espiritualidade" em gestação: é preciso colocar a "fé" no mercado. A elite fala em sacrifício da classe trabalhadora e da classe média. Sacrifício que tem como resultado a crescente marginalização de milhões de

\footnotetext{
${ }^{210}$ SIQUEIRA, Ruy Dos Santos. Da ritualização da sociedade ao fetiche consumogônico. São Paulo: UMESP, 2006.
} 
pessoas do sistema produtivo e, consequentemente, do mercado. A elite integrada no mercado (vida, econômico-social) são os principais adeptos desta nova espiritualidade, marcada também pela insensibilidade. ${ }^{211}$

Atualmente, experimenta-se nas cidades vários tipos de religiosidade. Há uma presença muito forte de diferentes manifestações de espiritualidade. Encontram-se "igrejas-supermercados" especializadas em vendas de produtos religiosos e bens simbólicos. Franz Hinkelammert e Hugo Asmann afirmam que a “idolatria do templo" são os shopping centers. O novo discurso é marcado pela competitividade (competição) e pelo individualismo, assim como o projeto de vida e ascensão social a qualquer custo.

O cotidiano das cidades, especialmente dos grandes centros urbanos, tem uma expectativa pela presença do sagrado. Homens, mulheres, crianças, jovens e idosos, pertencentes às diversas classes sociais, estão experimentando, no dia a dia das cidades, a solidão, o stress, a depressão e síndromes que comprovam a incapacidade do ser humano de viver sua humanidade de forma plena. As cidades são espaços desumanos. ${ }^{212}$ Numa desenfreada busca por humanidade, o indivíduo se torna animalesco, perde-se em seus próprios conflitos e se deixa contagiar por alucinantes propostas religiosas.

Num contexto como esse, cabe uma proposta libertadora que alcance o indivíduo em todos os aspectos existenciais. Não seria inadequado dizer que é preciso uma "libertação" (romper com determinados paradigmas) dessas religiões que não conduzem à Deus, que cumprem um papel manipulador e não colocam em prática os ensinos de Jesus; que não estão voltadas para a verdadeira libertação em todos os sentidos, como se propõe no "evangelho integral" (O Evangelho Todo, para o ser humano Todo a Todo tempo).

Deve-se considerar ainda que a América Latina é um contingente heterogêneo, pluricultural e plurilíngue, e que os diferentes grupos humanos não estão isolados, mas vivem lado a lado, inter-relacionando-se e se influenciando mutuamente. Os processos culturais da América Latina são dinâmicos, mutantes e complexos.

No continente latino americano vivem aproximadamente 500 milhões de habitantes, sendo que em torno de $70 \%$ são considerados pobres. Sendo assim,

\footnotetext{
${ }^{211}$ PINTO, C. C. A cidade é a minha paróquia. São Paulo: Editeo, 1996. p. 104.

${ }^{212}$ PINTO, C. C. A cidade é a minha paróquia. São Paulo: Editeo, 1996. p. 105.
} 
não se pode negligenciar de forma nenhuma as necessidades que tenham. ${ }^{213}$

A exploração tem sido uma marca na América Latina desde seu "achamento". A terra rica e produtiva despertou os olhares do europeu no sentido de se aproveitar de suas riquezas, o povo original e autóctone não tinha como avaliar o tipo de saque que estava sofrendo.

A Espanha foi uma grande exploradora das riquezas da América Latina, como afirma Galeano: Entre 1503 e 1660 chegaram ao porto de San Lúcar de Barrameda 185 mil quilos de ouro e 16 milhões de quilos de prata. A prata transportada para Espanha em pouco mais de um século e meio excedia três vezes o total das reservas europeias. E é preciso levar em conta que essas cifras oficiais são sempre minimizadas. Os metais arrebatados aos novos domínios coloniais estimularam o desenvolvimento europeu e pode-se mesmo dizer que o tornaram possível. $^{214}$

A partir de uma abordagem filosófica pode-se considerar o que pressupõe Arendt: Além das condições nas quais a vida é dada ao homem na terra e [...]a partir delas, os homens constantemente criam as suas próprias condições que, a despeito de sua variabilidade e sua origem, possuem a mesma força condicionante das coisas naturais. Neste contexto filosófico, as culturas são estabelecidas e perpetuadas entre os povos, e não foge à regra o povo latino. $\mathrm{O}$ que quer que toque a vida do ser humano, ou entre em duradoura relação com ela, assume imediatamente o caráter de condição da existência. Tudo que adentra o mundo humano, ou para ele é trazido pelo esforço humano, torna-se parte da condição humana.

A objetividade do mundo - o seu caráter de coisa ou objeto - e a condição humana complementam-se uma à outra; por ser uma existência condicionada, a existência humana seria impossível sem as coisas, e estas seriam um amontoado de objetos incoerentes, um não mundo, se esses artigos não fossem condicionantes da vida. ${ }^{215}$

Pode-se afirmar então que a exploração passa a ser uma condição que é difícil de ser alterada, a não ser que haja uma proposta impactante e

\footnotetext{
213 SALAMA,Pierre,Pobreza e exploração do trabalho na América Latina, São Paulo, Boitempo,1999,p,131

${ }^{214}$ GALENO, Eduardo. As veias abertas da América Latina. Rio de Janeiro: Editora Paz e Terra, 1980. p. 38.

${ }^{215}$ HANNDT, A. A Condição Humana. Rio de Janeiro: Forense Universitária, 1989. p. 23.
} 
transformadora, que afete o indivíduo nos seus mais elevados valores, mesmo que seja preciso for dar a sua própria vida para que experimente a libertação e viva um ideal ainda mais elevado.

A lógica colonialista europeia consistiu em depreciar a cultura dos povos colonizados. Segundo essa lógica, modernizar o mundo significava retirar qualquer resquício de envolvimento mitológico, através do espírito da razão, da ciência e do progresso. Contudo, não seriam essas novas categorias míticas? Encontra-se, ainda, nos escritos positivistas de Comte, uma tentativa de superação da etapa mítica, presente na clássica teoria dos três estados de progresso da humanidade. 1) $\mathrm{O}$ estado teológico, em que a humanidade vê o mundo e se organiza a partir dos mitos e das crenças religiosas; 2) O estado metafísico, baseado na descrença em um Deus todo-poderoso, mas também em conhecimentos sem fundamentação científica; 3) O estado positivo, marcado pelo triunfo da ciência, que seria capaz de compreender toda e qualquer manifestação natural e humana.

De acordo com essa teoria, o primeiro estado é o que se refere, especificamente, ao mito, Deus e religião, considerados estados primários de qualquer civilização. Esse estado - teológico - é simbolizado pela ignorância e pelo temor às forças sobrenaturais. Mito ${ }^{216}$, Deus, e religião são considerados estados primários (teológico) de qualquer civilização. É o estado da ignorância e do temor as forças sobrenaturais.

Surge assim a oposição entre os detentores do monopólio da gestão dos sagrados e os leigos, objetivamente definidos como profanos, no duplo sentido de ignorantes da religião e de estranhos ao sagrado e ao de administradores do sagrado. A base do princípio da oposição entre o sagrado e o profano se constitui, paralelamente, entre a manipulação legítima (religião) e a manipulação profana e profanadora (magia ou feitiçaria) do sagrado, quer se trate de uma profanação objetiva (ou seja, a magia ou a feitiçaria como religião dominada), quer se trate da profanação internacional (a magia como antirreligião) ou religião invertida). ${ }^{217}$

A partir dessa análise conceitual surge a principal variável desta reflexão, o poder. Parafraseando Kant, pode-se dizer que o poder é chamado ao serviço, mas inclinado à dominação. Esse é o seu paradoxo e sua trama. A raiz disso é que a

\footnotetext{
${ }^{216}$ Interpretação primitiva a respeito da origem do mundo.

${ }^{217}$ PIERRE, B. A economia das trocas simbólicas. São Paulo: Perspectiva. 1987. p. 43.
} 
potência busca a onipotência. Esse é o dinamismo autoexpansivo do poder, exposto de modo muito realista por Hobbes no Leviatã: "O poder quer sempre poder e mais poder".

É o que se chama hoje o "lado demoníaco" do poder, lado esse percebido desde sempre, mas posto à luz mais recentemente, depois da experiência histórica dos vários totalitarismos (de Jouvenel, Meinecke, Ritter, Tillich etc.). A teologia não vê nessa dinâmica interna do poder algo de sua estrutura criacional, mas de sua estrutura histórico-concreta.

A fonte da "lógica demoníaca" do poder se encontra no próprio ser humano em sua situação pecaminosa. De fato, porque "se tornou vulnerável pelo pecado" uma pessoa é incapaz de integrar totalmente suas pulsões vitais, no caso, a "vontade do poder", a ambição ou libido dominandi (Agostinho).

Segundo Clodovis Boff, A “tentação do poder" pertence à experiência quotidiana. Exprime-se na expressão: “O poder subiu-lhe à cabeça." Pricipatus virum ostendit - disse Bias, um dos sete sábios da Grécia, repetido por Tomás de Aquino (De Reg. Princ. I,10). Contudo, é verdade também que o holismo do poder acaba fracassado. É a tragédia de todo poder despótico. Pois nenhum poderoso faz o que quer. Encontra sempre pela frente outro poder, nem que seja a dignidade do mártir. A martyria faz frente à Hhybris. Perante o rei sempre se levanta o profeta, individual ou coletivo. ${ }^{218}$

Nesse contexto, o poder deve ser exercido a favor do fraco e do oprimido, não deve ser praticado ou exercido de forma egoísta, nem deve se aproveitar da ignorância ou os valores distorcidos para manipular ou exercer e estimular o fascínio dos desprovidos de capacitação intelectual.

Em detrimento a essa situação surge como proposta os conceitos do evangelho. O evangelho parte do real. Ora, o real do poder é a dominação. Daí o apelo à conversão do poder em serviço. As referências nesse sentido são muitas. Há duas tradições entrecruzadas: a relativa do "primeiro" e "grande", que é chamado a se tornar "último", "servo", “ escravo" (Mc 10,43-44; Mt 20,26-27 e Lc 22,24-29); e a tradição da criança", como o "maior" no reino deve ser igual a uma criança (Mc.9,33-37; Mt 18,1-5 e Lc 9,46-48.)

Mas existe também o exemplo do próprio Jesus: “O Filho do homem não

${ }^{218}$ BOFF, Clodovis, A igreja e o exercício do poder. Teologia do Poder. (Teses). p. 45. 
veio para ser servido mas para servir" (Mc.10,45); "Eu, que sou Mestre e Senhor, vos lavei os pés...” (Jo.13,14). A concepção que Jesus tem do poder está no nítido contraste que ele estabelece entre o poder-dominação das nações. "Não é assim entre vós": essa é a marca da ruptura revolucionária que apresenta Jesus, entre o poder vigente e um poder alternativo.

Essa visão não suprime a ideia de poder, mas a supera, dando-lhe outro conteúdo e outra direção. Surpreendentemente, é desse modo que Jesus recupera o sentido originário do poder que é e deve ser o serviço. O poder-dominação não é o poder verdadeiro. Governar homens não é o mesmo que dominar escravos, segundo Rousseau. De fato, é como serviço que o poder político foi apresentado na grande tradição antiga, especialmente a representada por Platão e Aristóteles.

Assim, o que serve aos interesses do povo merece de verdade o título de rei; o que serve a seus interesses chama-se tirano. O evangelho procura, pois, a "restitutio ou "reinventio" da verdade primária do poder na sociedade. Mas se isso for feito sob forma profética, é com um vigor e uma radicalidade que não se encontram paralelos na reflexão filosófica antiga. Desse modo, o Evangelho só faz radicalizar ao extremo o conceito racional do poder, o que dá a sua mensagem uma eficácia que a filosofia antiga desconhecia. ${ }^{219}$

É preciso não confundir o efeito de consagração que todos os sistemas de práticas e de representações religiosas tendem a exercer sobre o povo, de maneira direta ou imediata, no caso da religiosidade das classes dominantes, ou de maneira indireta, no caso da religiosidade das classes dominadas. Com efeito de conhecimento-desconhecimento que todos os sistemas de práticas e de representações religiosas exercem necessariamente, enquanto imposição de problemática, e que constitui de fato a mediação mais dissimulada pela qual se exerce o efeito de consagração.

Os esquemas de pensamentos e de percepção constitutivos da problemática religiosa podem produzir a objetividade que gera somente o desconhecimento dos limites do conhecimento (isto é, a adesão imediata sob a modalidade da crença ao mundo da tradição vivida como "mundo natural”) e do arbitrário da problemática, um verdadeiro sistema de questão que não é questionado. ${ }^{220}$

Se não se admitir e praticar a ética cristã, o espaço será cedido para a ética

\footnotetext{
${ }^{219}$ BOFF,Clodovis. A igreja e o exercício do poder. Teologia do Poder. (Teses). p. 49.

${ }^{220}$ PIERRE, B. A economia das trocas simbólicas. São Paulo: Perspectiva. 1987. p. 47.
} 
secular e para cultura política dos países. Sem essa conscientização, pode-se partir para a militância política apenas para tomar vantagens e em busca de status, poder, prestígio ou alguma vantagem materialista.

Robson Cavalcanti afirma que não há futuro nem presente para aqueles que desconhecem e desvalorizam seu passado, renegam ou desvalorizam ou até mesmo espiritualizam os ensinos políticos da palavra de Deus, e a construção teórica e a prática de uma ética política de expressão mais abrangente do compromisso ético do convertido. ${ }^{221}$

Quando se analisa a questão de se praticar uma postura teológica, ou o retorno do sagrado ao seu estado legítimo, se está afirmando que não se pode vender o que de mais sagrado foi deixado pelo Senhor Jesus Cristo. Este é o cerne do cristianismo: a estrutura da religião cristã é voltada para cuidar do órfão, do estrangeiro, da viúva e dos pobres.

\subsubsection{O poder- serviço ${ }^{222}$ na prática}

As ações de poder devem resultar no serviço a favor das pessoas. Não se pode exercer o poder para manipular ou coagir indivíduos. O poder usado para explorar, denigre o ser humano, a exploração do mais fraco traz à tona a má índole e expõe a opressão e a tirania do mais forte. A partir desses pontos serão

\footnotetext{
${ }^{221}$ ROBSON, C. No princípio era o Verbo. In: F. T. L., Curitiba (PR): Encontrão, 1986. p.179.

${ }^{222}$ O conceito do serviço cristão: No Antigo Testamento, o termo hebraico para serviço é abad, usando tanto no contexto religioso quando de trabalho. Um exemplo de serviço é a condição de servidão de Esaú em relação a Jacó (Gn. 25.23). Quando o termo serviço, em hebraico, está relacionado ao contexto religioso, tem o sentido de adoração. O verbo hebraico sarat também denota "ministrar, servir, oficializar", comumente usados para se referir aos trabalhos realizados no palácio real (II Sm. 13,17; I Rs. 10,5) ou nos serviços públicos (I Cr. 27,1; 28.1; Et. 1,10) Sarat aponta para a condição de "ministro" ou "servo", como Josué que servia a Moisés (Ex. 24,13; 33,11; Nm. 11,28) e aos anjos que servem a Deus (Sl. 104,4) O conceito bíblico de serviço, no Novo Testamento, vem do grego diakonia, do verbo diakoneo, e diz respeito, inicialmente, ao ato de servir às mesas (At. 6.1-6), serviço ministrado pelos diáconos (I Tm. 3,10,13). O ato de Jesus ter entregue a Si mesmo pelos outros é descrito como um ato de serviço (Mt. 20.28). O verbo douleuo, em grego, também se refere ao serviço do cristão, com uma singularidade, esse termo também é usado para "ser escravo", ou de "alguém que se conduz em total serviço ao próximo". Jesus destaca, em Mt. 6.24, que ninguém pode servir a dois senhores. Em Rm. 6,6, Tt. 3,3 e Gl. 4,8,9 Paulo explica que todos aqueles que se encontra fora da esfera da graça são servos do pecado. Mas quando passamos a servir a Cristo, passamos a servir uma ao outro em amor (Gl. 5,13). Em sentido amplo, o serviço cristão não está restrito àqueles que exercem o ministério de diáconos, pois desde os primórdios, os crentes serviam uns aos outros, conforme a necessidade de cada um (At. 4,32-37; II Co. 9,13) para a edificação do Corpo de Cristo (Ef. 4,12). AGOSTINHO, Santo. Trindade. São Paulo: Paulus, 1994. VIII 10, 14.
} 
estudados alguns princípios e exemplos apresentados no Novo Testamento que servirão como referencial teórico, a respeito do serviço e socorro aos fracos e oprimidos, pois segundo os ensinamentos de Cristo, o mais forte deve servir ao mais fraco.

É preciso elaborar ações para ser a voz daqueles que não têm voz. o cristão deve ser a mão amiga e proclamadora da verdade para aqueles que não são ouvidos pela sociedade, principalmente no ambiente da religião. Foi assim que Jesus desenvolveu seu ministério.

Através de suas ações ministeriais, Jesus deixou exemplos para serem seguidos. Com sua disposição para servir, ensinou lições para que os discípulos o imitassem. O apóstolo Paulo encarnou o serviço como ação principal do seu ministério. Suas atividades foram caracterizadas pela ajuda aos necessitados. Paulo afirmou: "Ai de mim se não pregar o evangelho..." (1 Co 9,16), "Sede meus imitadores assim como eu sou de Cristo..." (1 Co 11,1).

Analisando de forma generalizada, o serviço se evidencia através de ações a favor do próximo.

\begin{abstract}
Em termos gerais, o servir é um querer, atuar ou fazer através dele uma pessoa a atuar, não conforme seus próprios fins ou planos, mas sim tendo como finalidade a outra pessoa e com dedicação atender uma necessidade e disposição para ir aos outros. E um ato cuja liberdade está limitada e determinada pela liberdade da outra pessoa, um ato cuja glória chega a ser cada vez maior ao ponto de quem o faz e não se preocupa com sua glória, mas sim com a glória do outro. ${ }^{223}$
\end{abstract}

Fica a lição de Jesus: "Entre vós não será assim, ao contrário quem quiser ser o primeiro, deve ser o servo de todos" (Mc 10,43). Essa verdade tem sido ressaltada de forma veemente e ilustrativa em vários aspectos, com a intenção de ensinar e transmitir os princípios cristãos sobre o poder-serviço. Como disse Foster parafraseando Francisco de Assis: Sendo servo de todos, estou obrigado a servir a todos e administrar as palavras suavizadoras de meu Senhor. ${ }^{224}$

W. Law $^{225}$ entendia que a disciplina do serviço é que traz humildade à vida.

\footnotetext{
${ }^{223}$ GERHARD, B. A Primeira Epístola de Pedro. São Leopoldo-RS: Sinodal, 1979.

${ }^{224}$ FOSTER, Richard. Celebração da disciplina. Rio de Janeiro: Editora Vida 1984, p. 170.

${ }^{225}$ Willian Law (1686-1761): Teólogo e estudioso inglês. Estudou em Cambridge, porém por causa de suas convicções políticas foi proibido ao uso do púlpito, mas pregou através de seus livros. Dentre estes pode-se citar: Christian Perfection, Spirit of Love, Spirit of Prayer, e o mais conhecido de todos: A Serious Call To a Devout and Holy Life, publicado em 1728. A tese deste último livro é que Deus não se limita a perdoar nossa desobediência, ele nos chama à obediência, e para uma vida completamente centrada n'Ele.
} 
Ele aconselha a condescender em todas as fraquezas e enfermidades do próximo, ocultar suas fragilidades, enxergar o que ele tem de melhor, incentivar suas virtudes, aliviar suas necessidades, regozijar-se em suas prosperidades, compadecer-se de suas tristezas, receber sua amizade, ignorar suas indelicadezas, perdoar-lhe a malícia, ser servo de servos, e condescender em executar o mais inferior dos ofícios para os mais íntimos da humanidade.

"Aprenda esta lição: se você tem de fazer o trabalho de um profeta, você precisa não de um cetro mas de uma enxada", diz Bernardo de Claraval ${ }^{226}$. Se for feita uma analise através de simbolos: "Como a cruz é o símbolo da submissão, assim a toalha é o símbolo do serviço".

Poder também consiste na capacidade em potencial, a força ativa em operação; é o direito de ser ou de fazer alguma coisa; é qualquer forma de energia. Nas leis físicas, o poder é a opção em que a energia é convertida em trabalho. No ponto de vista da Bíblia, Deus é o Ser Todo-Poderoso.

A palavra "autoridade", que se traduz "exousia", vem da palavra latina "auctoritas", que, por sua vez, deriva de "auctor": aquele que aumenta, que faz avançar, progredir. Todos esses termos, que são habitualmente associadas à família do verbo "augere" (fazer crescer, aumentar, acrescentar) traçam, pois, os contornos da autoridade compreendida com a "capacidade de fazer crescer" ou “de ser o autor do crescimento de alguém”.

Percebe-se a capacidade de influenciar o outro. Quanto mais poder, mais capacidade de influência o indivíduo terá. Dependendo do caráter do agente será expresso o tipo de influência, tanto para o bem como para o mal: há pessoas que influenciam para ajudar ao outro, outras para explorar o mais fraco, ambas distintas entre si.

Agostinho $^{227}$ disse que há dois tipos de pessoas, porque há duas formas de

\footnotetext{
${ }^{226}$ Bernardo, nasceu em 1090, filho de pais ricos e poderosos, cresce um menino que gosta de meditação, estudioso e tímido. Seus pais o confiam aos cônegos de São Vorle, cuja linda igreja se ergue as margens do Sena. No convívio com grandes escritores ele lê os clássicos, Virgilio, Horácio, Cicero, etc. As lições dos mestres o marcaram para a vida inteira. Quando retorna ao castelo da família após a morte de sua mãe, decide ir para a Alemanha a fim de concluir seus estudos. Depois vai para a Abadia de Citetaux. Trabalha com serviço pesado e se dedica ao arado e ao brandir da foice. Aos 25 anos em companhia de doze monges, parte para criar uma nova abadia a de Bernardo de Claraval. RICHE, P. Vida de São Bernardo. São Paulo: Edições Loyola, 1991. p. $12-15$.

${ }^{227}$ Santo Agostinho é considerado um dos pais da Teologia, com sua principal obra De Trinitate, em quinze livros. Suas obras mais conhecidas, cujo interesse perdura, são as Confissões (Confessiones), obra autobiográfica, e a Cidade de Deus (De civitate Dei) em que discute o
} 
amor. Um amor santo, outro egoísta. Um se preocupa com o bem comum a favor do entendimento mútuo e da fraternidade espiritual; o outro procura submeter o bem comum ao próprio bem, satisfazendo a arrogância e a ânsia de domínio; um é submisso a Deus, enquanto o outro trabalha para igualar-se a Deus.

Enquanto um trabalha pela paz, o outro é insubordinado; um prefere a verdade às honras humanas; o outro anseia pelos louvores, ainda que sejam falsos; um é amigo, o outro é invejoso; um deseja para o próximo o mesmo que deseja para si, o outro deseja submeter o próximo a si mesmo; um ajuda os demais, está interessado neles; o outro se interessa por si mesmo.

\subsection{Conclusão e considerações finais}

Neste capítulo estudaram-se as fundamentações conceituais e teológicas a respeito do poder, começando com as terminologias adequadas para melhor entendimento a respeito do assunto.

Após a conceituação técnica foi desenvolvida uma análise dos aspectos teológicos a respeito do poder, abordando tanto os eixos da teologia quanto das ideologias, tendo em vista o ambiente da religião e seu diálogo como a teologia, também o contexto latino americano onde se estabelece a plataforma de análise, pois teologia se faz a partir do contexto em que o teólogo está inserido.

A partir da teologia, percebe-se que o poder é neutro, depende do caráter de quem o exerce, também se aborda a questão sobre as tentações a respeito do poder, o domínio vem à tona, a exploração sobre os mais fracos. A questão ética é fundamental para que o exercício do poder aconteça de acordo com os princípios ensinados por Deus.

É feita então uma análise do poder como serviço a partir do ministério do

problema do bem e o mal, as relações do mundo material e espiritual. Seu estilo literário era primoroso, tomando partido total da flexibilidade da língua. Era um formidável formador de frases, que muitas vezes se tornaram ponto de partida para controvérsias (como a da predestinação). Suas obras exerceram imensa influência sobre o pensamento filosófico-religioso de toda Idade Média. Sua doutrina trinitária é fundamental. Ensinou que não há subordinação entre as pessoas da Santíssima Trindade, como queriam Tertuliano e Orígenes. Seu pensamento reapareceria com Lutero e principalmente com Calvino e com os jansenistas (pertencente à doutrina de Cornélio Jansen, bispo de Ipres, sobre a graça e a predestinação), exercendo hoje, decisiva influência na teologia dialética de Karl Barth. Agostinho, Santo. As confissões. Quadrante-Sociedade de Publicações Culturais, 1999.p,128 
Apóstolo Paulo, pode-se se dizer que a consolidação do poder acontece quando o serviço se torna evidente. Tomando como base o exemplo de Jesus, que no seu ministério deixou exemplos a serem seguidos, quando se assume a posição de servo. Na pessoa do Apóstolo Paulo destaca-se a dedicação e a coragem para fazer os enfrentamentos necessários e ensinar para os seus cooperadores os fundamentos para o serviço cristão.

Para uma melhor compreensão, foram estudadas as diversas instâncias de poder na época de Jesus, levando em conta principalmente o poder religioso. A partir dessa compreensão, observou-se que Jesus apresenta caminhos e princípios que devem ser seguidos por aqueles que são vocacionados ou por outros que tem aspirações para tal. A figura principal no ministério cristão é o pastor, aquele que tem a tarefa de cuidar e de certa forma reproduzir os ensinamentos de Jesus. Após estudos percebe-se como o ministério pastoral midiático tem sido poluído por diferentes formas de ação correndo o risco de ser descaracterizado dos ensinos bíblicos a respeito do assunto.

Os perigos do poder pastoral devem ser evitados tendo em conta os ensinamentos do Mestre. Tendo em conta a abrangência dessa análise, este capitulo teve por objetivo analisar conceitos teológicos a respeito do ministério cristão e apontar caminhos preventivos e adequados para comunicar as palavras de salvação e justiça para a sociedade. 


\section{Ministério Midiático na Perspectiva do Poder- Serviço}

A partir da pesquisa ${ }^{228}$ desenvolvida para a tese, foi feita uma constatação: há falta de material teórico e teológico para pautar o ministério cristão midiático. As regras que têm sido seguidas por muitos obedecem aos padrões da mídia convencional. Mas é preciso uma análise bíblica e teológica para que aqueles que exercem esse serviço possam se pautar. Neste capítulo serão feitos alguns apontamentos que podem servir de referência para aqueles que atuam nessa área. A partir da interação com os líderes midiáticos pesquisados, serão abordados alguns tópicos que servirão de auxílio para aqueles que exercem a tarefa de influenciar milhares de pessoas. Arrisca-se a dizer que essa geração de pregadores do nosso tempo tem a melhor oportunidade já dada para os seres humanos na comunicação do evangelho, esse mundo virtual e sem fronteiras possibilita que todos habitantes do planeta possam ouvir a mensagem da salvação.

Pode se dizer que o ministério midiático tem sido desenvolvido de forma intuitiva e que existe uma expectativa da parte daqueles que exercem essa tarefa de um material conceitual e teológico que possa servir de referência para suas ações.

Para entender o ministério cristão midiático e refletir sobre ele, um referencial teológico a respeito do assunto será de grande valia, inclusive para aqueles que atuam nessa modalidade. $\mathrm{O}$ ministério cristão deve ser pautado no serviço, o qual, por sua vez, tem sido copiado dos modelos gerenciais modernos, que não levam em conta as pessoas e suas necessidades, pois desempenham um foco mais comercial, com a preocupação de melhor vender o produto apresentado na mídia. Assim, cabe àquele que se candidata ou que exerce o ministério seguir o exemplo de Jesus; este é o ponto de partida para que o ministério seja

\footnotetext{
${ }^{228}$ Pesquisa realizada nos meses de novembro de 2015 a janeiro de 2016, foram contatados quatro líderes cristãos midiáticos e expoentes no segmento protestante e católico, sendo dois padres e dois pastores. Esses líderes exercem o ministério midiático e têm um alcance de milhares de pessoas tanto no Brasil quanto em outros países. Foi dado liberdade de expressão para os líderes, e respeitou-se a confidencialidade de suas abordagens; além disso, não será citado o nome de cada líder entrevistado. A partir das considerações do entrevistados foram desenvolvidas abordagens com vistas a fundamentar o ministério midiático e oferecer material conceitual para o exercício da tarefa.
} 
consolidado.

O documento Pastores Davo Vobis afirma que no Antigo Testamento, a partir do profeta Jeremias, Deus faz uma promessa de cuidado para com o Seu povo, "Dar-vos-ei pastores segundo o Meu coração" (Jer 3, 15). Com essas palavras do profeta, Deus promete ao Seu povo que jamais o deixará sem pastores que os reúnam e os guiem: "Eu estabelecerei para elas (as minhas ovelhas) pastores, que as apascentarão, de sorte que não mais deverão temer ou amedrontar-se" (Jer 23, 4).

O povo de Deus, experimenta continuamente a realização desse anúncio profético e, na alegria, continua a dar graças ao Senhor. Ela sabe que o próprio Jesus Cristo é o cumprimento vivo, supremo e definitivo da promessa de Deus: "Eu sou o Bom Pastor" (Jo 10, 11).

Jesus, o grande Pastor das ovelhas (Heb 13, 20), confiou aos apóstolos e aos seus sucessores o ministério de apascentar o rebanho de Deus (Jo 21, 15-17; 1 Ped $5,2)$. Sem sacerdotes, de fato, a igreja não pode viver aquela fundamental obediência que está na essência da sua existência e da sua missão na história - a obediência à ordem de Jesus: "Ide, pois, ensinai todas as nações" (Mt 28, 19) e "fazei isto em minha memória" (Lc 22, 19; 1 Cor 11, 24), ou seja, a ordem de anunciar o Evangelho e de renovar todos os dias o sacrifício do Seu corpo entregue e do Seu sangue derramado pela vida do mundo ${ }^{229}$

O preceito pastoral acontece na igreja e a partir da igreja, o povo de Deus precisa ser orientado. Dessa forma, Deus constituiu pastores para orientar o seu povo, para ensinar e a cuidar daqueles que amam ao Senhor.

No Novo Testamento, tudo começa quando Jesus chamou aos doze. A diferença das instruções dadas aos setenta discípulos de Mat 10,1-16, e aos doze apóstolos são diferentes. Os doze não são enviados de dois em dois, para os apóstolos Deus indica uma orientação específica: na igreja primitiva, cada um dos doze era independente em virtude de seu carisma pessoal e do seu oficio, poder e autoridade.

Antes de Pentecostes, Jesus ainda não tinha orientado aos doze que pregassem um conhecimento mais profundo do mistério da salvação, mas que anunciassem que "o reino de Deus está próximo". A atividade de curar ao mesmo

\footnotetext{
${ }^{229}$ Papa João Paulo II. Pastores Dabo Vobis. Exortação Apostólica. 4. ed. Pós Sinodal, 1992.
} 
tempo em que se prega supõe que o reino não é simplesmente uma entidade espiritual, mas que aponta para a plena renovação do ser humano: espírito, corpo e alma.

Curar as enfermidades era uma ação sobrenatural (Mat 4,33-37,40; 5,18-26). O mesmo direito que os levitas do Antigo Testamento receberam, os doze herdaram: o direito de serem mantidos pela comunidade da fé (Nm 18,31; I Cor $9,17-18) .{ }^{230}$ João Calvino, teólogo protestante, faz a seguinte declaração a respeito dos Apóstolos:

\begin{abstract}
Apóstolos, e todos os ministros eclesiásticos, visto que são todos enviados pelo Senhor e são seus mensageiros. Contudo, visto que importava muitíssimo que se tenha seguro conhecimento acerca da missão desses que apresentariam uma mensagem nova e inaudita, foi conveniente que esses doze, a cujo número mais tarde se acrescentou Paulo [At 9,15; Gl 1,1], sejam mencionados acima dos outros por um título especial. Na verdade, o próprio Paulo, em alguma parte ( $\mathrm{Rm} 16.7)$, atribuiu este título a Adrônico e Júnias, a quem diz que eram insignes entre os apóstolos; quando, porém, quer falar acuradamente, o atribui exclusivamente àquela primeira ordem. E este é o uso comum da Escritura. Os pastores, entretanto, exceto os que regem, um a um, determinadas igrejas a si designadas, mantêm com os apóstolos o mesmo cargo. Além disso, de que natureza seja esse encargo ainda ouviremos mais claramente. ${ }^{231}$
\end{abstract}

O ministério cristão não é uma invenção humana; antes, é uma instituição do próprio Deus. Pois lemos que Paulo e Barnabé estabeleceram presbíteros nas igrejas individuais da cidade de Listra, de Antioquia, de Icônio (At 14.21-23); e Paulo mesmo ordena a Tito que constitua presbíteros de cidade em cidade ( $\mathrm{Tt}$ 1.5). Assim, em um lugar (Fp1.1) se menciona os bispos dos filipenses e em outro (Cl 4.17) Arquipo, bispo dos Colossenses.

E Lucas se refere ao discurso dirigido por Paulo aos presbíteros da igreja de Éfeso (At 20.17-35). Portanto, quem quer que haja assumido o governo e o cuidado de uma igreja saiba que foi atado a esta lei da divina vocação; não como se "atado à gleba", como dizem os jurisconsultos, isto é, o sujeito é como que "preso", mas enquanto assim o requeira o benefício público, desde que isso se faça retamente e em ordem.

$\mathrm{Na}$ igreja de Jerusalém aparecem três categoria: apóstolos, anciãos e

\footnotetext{
${ }^{230}$ BROWN, R., FITZMYER, J. A., MURPHY, R. E., CARM, O. Comentário Bíblico San Jerónimo. v. 3. Madrid: Ediciones Cristiandad, 1972. p. 372.

${ }^{231}$ CALVINO, João. As Institutas da Religião Cristã: Edição especial com notas para estudo e pesquisa. São Paulo: Cultura Cristã, 2008.
} 
auxiliares. A antiga hierarquia precisava se reestruturar. O termo discípulos ${ }^{232}$ não havia sido aplicado aos cristãos desde Lc 22,45; mas reaparece na história de Paulo (Atos 9,1.10.19). Quanto ao termo helenistas, desde João Crisóstomo se havia entendido como "judeus de fala grega". Cadbury susteve que hellenistés significa simplesmente Hellen, "um grego", porque era um derivado de hellenizó, que significa "viver como um grego", não "falar em grego".

Helenistas era o nome dos membros gentios da igreja da Palestina. No livro de Atos, Lucas não dá indício de uma igreja judaico-cristã. Sendo que Paulo era um judeu da diáspora que falava grego, e se chama "hebreu" a si mesmo (Fp 3,5), pode se concluir que os "helenistas" eram "judeus que só falavam grego" enquanto "judeus que eram capazes de expressar-se em grego".

No relato de Lucas, os doze são os apóstolos $(1,26 ; 2,14)$. Posteriormente há aqueles são chamados diakonoi (auxiliares) e mais tarde "diáconos", seu trabalho é uma diakonia (Atos 6,1), "serviço" e deles se dizem que "servem" (diakonein). Essa ideia básica de ministério na igreja estruturada não difere do "serviço da palavra", que é a tarefa dos apóstolos; em ambos casos, se "serve", de boa forma, cheios do Espírito Santo (Nm 27,18). Semelhantes qualidades poderiam parecer supérfluas com vistas à função para que foram selecionados.

Quanto ao ministério ordinário de beneficência da igreja, o Senhor tenciona que a igreja cuide dos pobres. Ele fez alusão a esse dever quando disse aos seus discípulos: "Porque os pobres sempre os tendes convosco", (Mt 26.11; Mc 14.7).

Por meio de uma comunhão de bens, a Igreja Primitiva providenciou para que a ninguém faltasse nada do necessário para a vida (At 4,34). "E quando as viúvas dos gregos estavam sendo negligenciadas na ministração diária, os apóstolos providenciaram para que sete homens bem qualificados fossem encarregados daquele serviço necessário" (At 6.1-6). Eles deviam "servir às mesas", o que parece significar, neste contexto, supervisionar o atendimento às mesas dos pobres, ou providenciar uma divisão equitativa das provisões que eram postas nas mesas. Diáconos e diaconisas são mencionados repetidamente na Bíblia (Rm 16,1; Fp 1,1; 1 Tm 3,8-12). Essa figura e sua função correspondente

\footnotetext{
${ }^{232}$ Discípulo é aquele que se coloca de forma voluntária debaixo da direção de seu mestre e que compartilha suas ideias. Essa palavra quase ausente no Velho Testamento é usada no Judaísmo (Heb talmid) que se eleva ao termo de uma tradição bíblica e se fala no Novo Testamento (Greg matherste) porém com o sentido original que Jesus a usa. DUFOUR, Xavier Leon. Vocabulário de Teologia Bíblica. Barcelona: Xavier, HERDER, 2001. p. 213.
} 
têm uma conotação pastoral.

Além disso, o Novo Testamento contém muitas passagens que instam sobre a necessidade de se fazerem ofertas ou coletas para os pobres (At 20.35; 1 Co 16.1, 2; 2 Co 9.1, 6, 7, 12-14; Gl 2.10; 6.10; Ef 4.28; 1 Tm 5.10, 16; Tg 1.27; 2.15, 16; 1 Jo 3.17). Assim, não pode haver dúvida quanto ao dever da igreja nesta questão. E os diáconos são os oficiais incumbidos da tarefa de realizar o trabalho da beneficência cristã com referência a todos os necessitados da igreja.

Cabe-lhes planejar métodos e meios para coletar os necessários fundos, devem responsabilizar-se pelo dinheiro coletado, e devem providenciar a sua prudente distribuição entre a comunidade da familia da fé e aos outros que necessitam de ajuda. Contudo, o seu trabalho não se limita a este oferecimento de auxílio material. Eles devem também instruir e consolar os necessitados (função pastoral). Em todo o seu trabalho, eles devem considerar seu dever de aplicar os princípios espirituais quando estão dando cumprimento ao seu serviço.

Lamentavelmente, no entanto, esta função está sendo negligenciada em muitas igrejas hoje. Há a tendência de partir da suposição de que se pode deixar que o Estado supra as necessidades até dos pobres da igreja. Mas, ao agir com base nesse pressuposto, a igreja negligencia um dever sagrado, empobrece a sua vida espiritual, priva-se da alegria que se experimenta ao atender às necessidades dos que padecem, e priva os que estão passando por dificuldades, os que se veem em condições deprimentes, e os que muitas vezes caem no desânimo, da consolação, da alegria das ministrações do amor cristão, em regra inteiramente alheias às obras de caridade administradas pelo estado que as vezes visam apenas promover suas ações politicas. ${ }^{233}$

Os anciãos se mostraram como verdadeiros pastores do rebanho (I Pd 5,15). Os "presbyteroi" teriam confiada uma função oficial (administrativa, I Tm $5,17)$ na comunidade cristã. Esses indivíduos eram designados pelos apóstolos itinerantes (At 14,23). Nota-se que Pedro escreve como "sympresbyteros", "copresbítero". O cuidado pastoral do rebanho de Deus está confiado a esses “anciãos", como em Atos 20,17,28. Seu dever é "vigiar" e "cuidar" do rebanho na disciplina e na doutrina. Alguns manuscritos citam episkopountes (inspecionando); não por proveito próprio. Semelhante motivação tem que estar

\footnotetext{
${ }^{233}$ BERKHOF, L. Teologia Sistemática. São Paulo: Editora Luz Para o Caminho, 1990.
} 
muito longe dos pensamentos dos que são anciãos da Igreja de Deus (Ti 1,7; I Tim $3,8)$.

No Novo Testamento, o próprio Espírito de Cristo introduz a esse ministério aqueles que foram escolhidos de entre os irmãos. Por meio do gesto da imposição das mãos (At 6, 6; $1 \operatorname{Tim} 4,14 ; 5,22 ; 2 \operatorname{Tim} 1,6$ ), que transmite o dom do Espírito, eles são chamados e habilitados a continuar o mesmo serviço de reconciliar, de apascentar o rebanho de Deus, e de ensinar (At 20, 28; 1 Ped 5, 2).

Portanto, os presbíteros são chamados a prolongar a presença de Cristo, sumo pastor, atualizando o seu estilo de vida e tornando-se como que a sua transparência no meio do rebanho a eles confiado. Assim se lê, de modo claro e preciso, na Primeira Carta de Pedro: "recomendo aos presbíteros que estão entre vós, eu presbítero como eles, testemunha dos sofrimentos de Cristo e participante da glória que se deve manifestar: apascentai o rebanho de Deus que vos foi confiado, olhando por ele não constrangidos, mas de boa vontade segundo Deus, não por ganância, mas por dedicação; não como dominadores sobre aqueles que vos foram confiados, antes vos tornando modelo do rebanho. E quando aparecer o supremo Pastor, recebereis a coroa eterna da glória" (1 Ped 5,1-4).

Os presbíteros são, na Igreja e para a Igreja, uma representação sacramental de Jesus Cristo, cabeça e pastor, e devem proclamar a Sua palavra com autoridade, repetindo os seus gestos de perdão e oferta de salvação, com o batismo, a penitência e a eucaristia, exercitando a sua solicitude até o dom total de si mesmos, pelo rebanho que reúnem na unidade e conduzem ao Pai por meio de Cristo no Espírito. Numa palavra, os presbíteros existem e agem para o anúncio do Evangelho ao mundo e para a edificação da Igreja em nome e na pessoa de Cristo Cabeça e Pastor ${ }^{234}$.

Mas, o que dizer dos pastores? Paulo fala não apenas em relação a si próprio, mas de todos eles, quando diz: "Assim nos considere o homem como ministros de Cristo e despenseiros dos mistérios de Deus" [1Co 4.1]. Igualmente, em outro lugar: "Importa que o bispo seja pertinaz nessa palavra fiel que é segundo a doutrina, para que seja poderoso para exortar mediante a sã doutrina e para refutar os contradizentes" (Tt. 1.7,9).

Analisar a "pastoral" equivale a reconhecer que esta função na Igreja tem que se

\footnotetext{
${ }^{234}$ Papa João Paulo II, Pastores Dabo Vobis, Exortação Apostólica, Pós Sinodal, 1992.
} 
concretizar em meio aos conflitos da sociedade, que a luta frente aos poderes que se opõem a Cristo é inevitável: "pensem em Jesus, que sofreu tantas contradições da gente má, e não se cansarão e nem desanimarão. Vocês estão enfrentando o mal, mas todavia não têm tido que resistir até o sangue" (Hb 12.34). Por isso, a pastoral deve reconhecer sua relação com aqueles aspectos da vida humana, onde há tensões, das quais as de caráter político são de suma importância. É ao povo seguidor de Jesus, formado por aqueles que hoje integram seu movimento (e que durante anos na Igreja Primitiva era conhecido como "os do caminho"), que compete cumprir a função pastoral. Para isso vão contar com força e inspiração do Espírito Santo. É ao binômio unido "Espírito-povo" que lhe é dada a função pastoral. $^{235}$

Destas e de passagens afins, é possível inferir que também na função dos pastores estas são as duas partes primordiais: anunciar o evangelho e ministrar os sacramentos. No entanto, a maneira de ensinar consiste apenas não em discursos públicos, mas diz respeito também às admoestações particulares e às ações práticas.

Assim sendo, Paulo cita os efésios como suas testemunhas de que daquelas coisas que lhes eram do interesse a nada se esquivou que lhes anunciasse e os ensinasse publicamente e de casa em casa testificando a judeus, ao mesmo tempo para os gregos, o arrependimento e a fé em Cristo (At 20.20, 21). Igualmente, pouco depois diz que não cessou de, com lágrimas, admoestar a cada um deles (At 20.31). O ministério pastoral faz parte dos planos de Deus para o cuidado do seu povo, através de serviço a ação cuidadora de Deus é revelada entre os seres humanos.

\subsection{A figura do pastor no ministério cristão midiático}

A imagem do pastor é uma metáfora estabelecida, uma linguagem figurada do antigo oriente para designar os governantes, assim como "apascentar" equivale frequentemente a "governar". É o pastor que conduz o rebanho para o local de bons pastos e que multiplica a gordura e o leite das ovelhas nos apriscos. O ofício pastoril do rei abraça toda a atividade governativa, inclusive a expectativa pelo bem-estar econômico e político do país.

No Antigo Testamento, o próprio Yahveh é designado como o "pastor de

235 ANA, Júlio Santa de. Pelas trilhas a caminho do Reino. São Paulo: Imprensa Metodista, 1998. p. 38. 
Israel", e se aplicam diversas imagens do mundo dos pastores ou do pastoreio (S1 80,2-4). Segundo Eichrodt, a imagem pastoril designa "a bondade de Yahveh como cumprimento da aliança que estabeleceu uma vez com Israel"; correspondente a Israel como rebanho de Yahveh: "Pois nós somos o teu povo, o rebanho dos teus pastos" 236 .

Como diz o teólogo João Calvino: Contudo, não se pretende expor minuciosamente os dotes do bom pastor, um a um, mas apenas indicar para os que professam e os que se chamam pastores, isto é, para presidirem à igreja de tal forma que não têm uma dignidade ociosa, antes que, com a doutrina de Cristo, instruem o povo à piedade, administram os sagrados mistérios e preservam o exercício da disciplina.

Pois todos quantos foram postos por atalaias na igreja, o Senhor lhes anuncia que, se alguém pereça por ignorância, em razão de negligência deles, ele requererá de suas mãos seu sangue $(\mathrm{Ez} 3.17,18)$. Também a todos eles compete o que de si diz Paulo: "Ai de mim se não pregar o evangelho, quando uma dispensação me foi confiada (1Cor 9.16, 17).Enfim, o que os apóstolos fizeram para o mundo inteiro, isso cada pastor deve a seu rebanho, para o qual foi designado.

\begin{abstract}
Para ficar parecido verdadeiramente com o Mestre é necessário assumir o mandamento do amor, que Ele quis chamar seu e novo: "Amem-se uns aos outros, como eu os amei" (Jo 15,12). Este amor, com a medida de Jesus, com total dom de si, além de ser o diferencial de cada cristão, não pode deixar de ser a característica de sua Igreja, cujo testemunho de caridade será o primeiro anúncio, "todos reconhecerão que sois meus discípulos" (Jo 13,35). No seguimento de Jesus Cristo, praticamos as bem-aventuranças do Reino, o estilo de vida do próprio Jesus: seu amor e obediência ao Pai, sua compaixão frente à dor humana, sua proximidade aos pobres e aos pequenos, sua fidelidade à missão seu amor até a doação de sua vida. Hoje, contemplamos a Jesus Cristo tal como os Evangelhos nos transmitiram para conhecer o que Ele fez e para discernir o que nós devemos fazer nas atuais circunstâncias ${ }^{237}$
\end{abstract}

Socialmente falando, isso significa ter a disposição para renunciar ao conforto e à segurança de sua própria formação cultural, a fim de se doar em serviço aos indivíduos necessitados. Essa é uma missão encarnada, seja ela evangelística, social ou mesmo ambas, que exige uma custosa identificação com

\footnotetext{
${ }^{236}$ JOSEF, B. El Evangelio Segun San Juan. Barcelona: Editorial Herder, 1984. p. 87.

${ }^{237}$ CELAM. Documento de Aparecida. Brasília: CNBB, 2007.
} 
as pessoas em sua real situação. ${ }^{238}$

$\mathrm{Na}$ América Latina temos muitas respostas teológicas experimentais a essa responsabilidade. Há numerosas agências cristãs de serviço social que estão tratando, de uma ou outra forma, de ministrar as necessidades do povo latinoamericano. Sem dúvida, faz falta uma reflexão crítica pastoral sobre o significado dessa ação no contexto socioeconômico, político e cultural da América Latina. Uma reflexão que analise o papel que compete desempenhar a comunidade de fé nessa situação. Uma reflexão que absorva profundamente, examinando os problemas pessoais e estruturais das pessoas, as famílias, as comunidades, cidades e países a quem servem as referidas agencias, assim como os problemas profundos da existência (vida, culpa, morte, etc.). Uma reflexão que levante a pergunta de como introduzir o evangelho feito carne em sua situação socioeconômica e cultural, ao nível de sua vida íntima e pessoal ${ }^{239}$.

Jesus anunciou o governo de Deus de uma maneira única e inimitável. É certo que a mensagem de Deus também deve ser anunciada com a proclamação da salvação, e depois ajudar as pessoas a seguirem esse caminho. E os que o aceitarem devem fazê-lo assim como Ele fez. Estes, porém, só conseguem fazê-lo a mandato dEle e em Seu nome, participando daquilo que Ele fez.

Com simplicidade Jesus acompanhava o dia a dia das pessoas, discipulando aqueles que estavam interessados, proclamando e praticando os valores do reino de Deus, compreendendo e exercendo a vontade do Pai, rompendo com as instituições religiosas de seu tempo e não se deixando levar pelas vaidades pessoais, estas e outras posturas tornaram-se as armas de Jesus para incomodar, questionar e apresentar um novo caminho para a humanidade.

Assim deve ser o ministério cristão midiático, o modelo já está proposto, cabe aos que exercem o serviço cristão e aqueles que postulam a esse cargo seguir o modelo de Jesus, o formato o conteúdo e as propostas do mestre estão disponíveis para aqueles que se propuserem a praticá-las.

\subsection{O ministério midiático tem sido desenvolvido num ambiente pós-moderno}

A proclamação da fé jamais se dirige ao ser humano num vazio, porém sempre a homens e mulheres que estão vivendo em uma época histórica e numa

\footnotetext{
${ }^{238}$ JOHN, S. O cristão em uma sociedade não cristã. 1989,p.41.

${ }^{239}$ COSTA, Orlando E. Evangelizacíon contextual, fundamentos teológicos e pastorais. San José: Ed. Sebila, 1986. p. 89.
} 
sociedade concreta. Sendo assim, não se pode pensar na proclamação da fé sem levar em conta o momento histórico, social e cultural que o indivíduo está inserido. A realidade de vida, o cotidiano e o contexto em que a pessoa existe deve ser levado em conta.

Pensando na atual sociedade pluralista, instável, diversificada, participativa, secularizada, dominada por uma racionalidade de cunho científico experimental e econômico, assim também como pragmática e utilitarista, que vê o discurso cristão apenas como mais um entre tantos que são proclamados. ${ }^{240} \mathrm{O}$ crescimento dos que se declaram sem religião e a indiferença de muitos fiéis com relação ao magistério eclesiástico, além do surto das religiões esotéricas e a religiosidade separada da instituição são alguns dos sintomas socioculturais da sociedade contemporânea.O tema da pós-modernidade está em evidência nos estudos atuais. "As características da pós-modernidade podem ser resumidas em alguns pontos: 1) propensão a se deixar dominar pela imaginação das mídias eletrônicas; 2) colonização do seu universo pelos mercados (econômico, político, cultural e social); 3) celebração do consumo como expressão pessoal; 4) pluralidade cultural; 5) polarização social devido aos distanciamentos acrescidos pelos rendimentos; 6) falências das metanarrativas emancipadoras como aquelas propostas pela Revolução Francesa: liberdade, igualdade e fraternidade". ${ }^{241}$

Se alguns autores entendem essa fase como uma ruptura com o moderno, outros afirmam ser uma transformação do moderno, uma mistura de conceitos modernos com os eixos da tecnologia. Vários teóricos têm emitido opinião a esse respeito e essas discussões revelam a complexidade do tema, pois essa transformação tem gerado novas formas de pensar etc.

Nas formulações de Huyssen ${ }^{242}$, apesar do pós-moderno estar longe de tornar o moderno obsoleto, oferece-lhe novas interpretações, apropria-se de muitas de suas estratégias, ideias e conceitos, inserindo-os e fazendo-os operar em

\footnotetext{
${ }^{240}$ Uma reportagem publicada na Folha de São Paulo mostra que o número de evangélicos que não mantêm vínculo com nenhuma denominação cresceu significativamente nos últimos anos. Os dados foram baseados em uma pesquisa do Instituto Brasileiro de Geografia e Estatística (IBGE) sobre "Orçamentos Familiares". Ela mostra que em 2003 era apenas 4\% dos evangélicos que não mantinham ligação com uma igreja e que em 2009 esse número já era de 14\%, um salto de 4 milhões de pessoas. Esse número representa pessoas que apesar de continuarem se assumindo como evangélicas, não frequentam nenhuma denominação, algo parecido com os católicos não praticantes. Também entram nessa amostragem as pessoas que frequentam duas e até mesmo três igrejas, sem criar vínculo com nenhuma. A pesquisa também revelou queda de fiéis entre católicos e protestantes históricos e também o crescimento das pessoas que se declaram sem religião e entre os neopentecostais. Os sem religião representavam $5,1 \%$ da população e hoje já são $6,7 \%$. Embora a categoria seja em geral identificada com ateus e agnósticos, pode incluir quem migra de uma fé para outra ou criou seu próprio "blend" de crenças - o que reforça a tese da desinstitucionalização. Disponível em: <http://noticias.gospelprime.com.br/cresce-o-numero-de-evangelicos-sem-ligacaocom-igrejas $>$. Acesso em: 30/05/2015.

${ }^{241}$ FRITJOF, C. O Ponto de Mutação. São Paulo: Cultrix, 2000. p,38

${ }^{242}$ HUYSSEN, A. Mapeando o pós-moderno. In: Hollanda, H. B. de (Org.). Pós-Modernismo e Política. Rio de Janeiro: Rocco, 1992. p. 23.
} 
novas perspectivas.

Os pós-modernos parecem marcar posições opostas ao que eles caracterizam como a linha modernista acerca da morte do sujeito, trabalhando em direção a novas teorias e práticas dos sujeitos na fala, na escrita e na ação. A questão da constituição da subjetividade por códigos, textos, imagens e outros artefatos culturais vem sendo cada vez mais levantada como uma questão a ser enfrentada. Segundo Huyssen, "não é certamente por acidente que as questões sobre subjetividade e autoria têm surgido com grande vigor no contexto pós-moderno". 243

Quadro 1 - Uma análise da pós-modernidade com perspectivas pastorais

\section{Fundamentos Pretende alcançar o sujeito}

a) deve levar em conta o momento histórico, social e cultural que o A proclamação da indivíduo está vivendo;

fé não ocorre num b) precisa manter padrões de conduta e aparência que o grupo social vazio associa a ele;

c) incorpora valores oficialmente reconhecidos pela sociedade.

Sociedade pluralista, instável, diversificada, participativa, As marcas da secularizada, dominada por uma racionalidade de cunho científico sociedade atual experimental e econômico assim também como pragmática e utilitarista.

a) emergem como produto da interação social e socialização;

Os que se b) a indiferença de muitos fiéis com relação ao magistério declaram sem eclesiástico, o surto das religiões esotéricas e a religiosidade separada religião da instituição.

a) é aquele que reage, contesta qualquer forma de controle;

b) não é só individualizado nem só racionalizado, é o ator que articula ambas as dimensões para se construir como sujeito;

As reações do

c) impossível separar indivíduo da sua situação social;

sujeito pós-

d) só existe como movimento social, como contestação lógica da moderno ordem;

e) age a partir da razão e do afeto;

f) age a partir do desejo próprio e da relação com o outro, da autonomia e da interdependência.

Alternativa conceitual para alcançar o sujeito

A nova evangelização, a mensagem do evangelho com uma roupa nova mas com o mesmo conteúdo histórico e Bíblico.

Nessa base, a teologia deve se fazer presente apresentando os eixos e os

${ }^{243}$ HUYSSEN, A. Mapeando o pós-moderno. In: Hollanda, H. B. de (Org.). Pós-Modernismo e Política. Rio de Janeiro: Rocco, 1992. p. 28. 
fundamentos do cristianismo. Se os teólogos se omitirem, os princípios cristãos serão tratados de forma relativa e a ética e a moral cristã serão relegadas a um segundo plano; se não existir juízo de valor perante as ações do sujeito na sociedade, a humanidade ficará à deriva, sem um referencial moral para seguir.

Os movimentos, ecológicos e raciais trouxeram à tona questões políticas, sociais e culturais que, se antes estavam à margem das discussões, são, no contexto atual, objetos de investigação crítica e análises conceituais. Por sua vez, a teologia deve emitir opinião a respeito desses temas, e a igreja tem a responsabilidade de apresentar os caminhos bíblicos para a reflexão, deve lançar luz ao tema, fundamentada nos valores e princípios cristãos.

E é exatamente nesse ambiente da emergência de novos movimentos sociais que surgem novos grupos, novas vozes, novos sujeitos, antes excluídos da ação comunicativa e intelectual, conduzindo a novas interpretações da história, das relações sociais e de outro sujeito que, diferentemente de Giddens, transcende as fronteiras de uma modernidade eurocêntrica (tendo a Europa como centro de referência conceitual). ${ }^{244}$

A este processo de ruptura, Huyssen tende a caracterizar como processo de emergência de um sujeito pós-moderno. Neste sentido, no meio ou nas fronteiras deste debate. "A nova evangelização, uma abordagem teológica contextualizada, uma ação fundamentada na teologia Bíblica" ${ }^{245}$, apresenta conceitos bíblicos e princípios cristãos que devem ser seguidos por uma sociedade que transcende aos seus conceitos teóricos.

\subsection{O ministério midiático frente a teoria da ação comunicativa de Habermas.}

O desenvolver da pesquisa uma constatação foi feita, aqueles que estão atuando no ministério cristão midiático tem agido de forma espontânea, falta uma base teórica para servir de referência para suas ações. Percebe-se determinados

\footnotetext{
${ }^{244}$ HUYSSEN, A. "Mapeando o pós-moderno". In: Hollanda, H. B. de (Org.). Pós-Modernismo e Política. Rio de Janeiro: Rocco, 1992.

${ }^{245}$ CATÃO, Francisco. A Nova Evangelização. Revista de Cultura Teológica. ISSN (impresso) 0104-0529 (eletrônico) 2317-4307 74 (2011): 11-29.
} 
comportamentos que acabam reproduzindo certos fundamentos desenvolvidos na sociedade sem se dar conta dos resultados e as implicações. Pensando nessa situação cabe analisar os conceitos relacionados a ação comunicativa de Habermas e sua influência na sociedade midiática e também sua influência no ambiente da religião.

Habermas (1929) é um filósofo e sociólogo alemão contemporâneo, que, ao lado de Gadamer, é o mais importante filósofo alemão do pós-guerra. Ele se coloca como continuador e inovador da tradição "antiacadêmica", sobretudo aquela ligada a Karl Marx e ao, assim chamado, "marxismo ocidental", uma vez que nas suas reflexões não há espaço para o marxismo oriental-leninista. Até 1979 o seu nome foi associado à Escola de Frankfurt.

Habermas aproximou-se de Marx mediante as leituras dos marxistas ocidentais como Luckács e Korsch. Entre os anos de 1956 e 1961 foi assistente de Adorno. ${ }^{246} \mathrm{O}$ principais representantes da Teoria Crítica da Escola de Frankfurt são Adorno (1903-1969), Marcuse (1898-1979), Horkheimer (1895-1973) e Benjamin (1892-1940). Não obstante as diferenças de pensamento desses filósofos, um tema perpassa a obra de todos eles: a crítica radical à sociedade moderna. Esses autores desenvolveram uma análise em que a sociedade deve ser mapeada e orientada em função do sujeito ${ }^{247}$.

Duas coisas chamaram a atenção de Habermas para Adorno: o fato de falar de Marx como se fosse um contemporâneo e a ignorância em relação a Heidegger e à filosofia alemã recente. Diferentemente de Adorno, Habermas mantinha contato com a tradição filosófica recente. Em 1981, diz em entrevista que o seu caminho autônomo o levou a temáticas comuns à da Escola de Frankfurt. ${ }^{248}$

Ele estuda a influência da intelectualidade hebraica na tradição alemã de Kant aos tempos atuais. Segundo ele, quase todos os pensadores originais desta tradição filosófica são judeus. Os raros não hebreus foram, no século $\mathrm{XX}$, abertamente antissemitas e foram os únicos a continuar ensinando na Alemanha nazista. ${ }^{249}$

Com o processo de modernização, passou a prevalecer nas sociedades

\footnotetext{
${ }^{246}$ HABERMAS, J. Direito e democracia:entre facticidade e validade. RJ: Tempo Brasileiro, 1997.

${ }^{247}$ HABERMAS, J. Técnica e ciência como ideologia. In: Os pensadores. São Paulo: Abril Cultural, 1975.

${ }^{248}$ HABERMAS, J. Discurso Filosófico da Modernidade. Lisboa Publicações D. Quixote, 1990.

${ }^{249}$ HABERMAS, J Consciência Moral e Agir Comunicativo. RJ: Tempo Brasileiro, 1989.
} 
industriais uma forma de racionalidade instrumental ${ }^{250}$. Essa racionalidade definese pela relação meios-fins, ou seja, pela organização de meios adequados para atingir determinados fins ou pela escolha entre alternativas estratégicas com vistas à consecução de objetivos.

Habermas partilha dessa crítica. Não permanece, no entanto, no momento da negatividade, mas tenta salvar a razão da perplexidade e do pessimismo. Ao repensar a ideia de razão e racionalização, ele busca superar as oposições que transpassam a cultura contemporânea, que, como resume McCarthy, são "modernidade versus pós-modernidade, racionalismo versus relativismo, universalismo versus contextualismo, subjetivismo versus objetivismo humanismo versus 'morte do homem', etc.". ${ }^{251}$

Habermas busca superar o conceito de racionalidade instrumental, ampliando o conceito de razão, para o de uma razão que contém em si as possibilidades de reconciliação consigo mesma: a razão comunicativa. Serão apresentados a seguir esses dois conceitos básicos no pensamento de Habermas.

A análise de Habermas possibilita um horizonte para o pensamento no qual ele não se sustenta sozinho, mas pela articulação de movimentos sociais emancipados da articulação político-partidária, crítica aos resultados da política pós Segunda Guerra, e que dê luz aos modelos de racionalidade comunicacionais, o que estreitaria as relações entre sociedade civil e a centralidade do Estado.

As análises realizadas por Habermas em $O$ Discurso Filosófico da Modernidade (2002) são exemplos de alguns processos reflexivos para a consolidação de uma agenda filosófica na qual linguagem e pensamento concretizam-se no mundo da vida. “[...] a consciência transcendental deve-se concretizar-se na prática do mundo da vida, adquirir carne e sangue em encarnações históricas". ${ }^{252}$

Com sua teoria, Habermas pretende mostrar que as ideias de verdade, liberdade e justiça inscrevem-se de forma quase transcendental nas estruturas da

\footnotetext{
${ }^{250}$ No seu livro "Eclipse da Razão" publicado em 1955, Horkheimer define mais amplamente o conceito racionalidade instrumental. Ele distingue duas formas de razão: a razão subjetiva (interior) e razão objetiva (exterior).

${ }^{251}$ HABERMAS, J. Direito e democracia: entre facticidade e validade. RJ: Tempo Brasileiro, 1997.

${ }^{252}$ JURGEN, H.S. Dialética e Hermenêutica - para a crítica da hermenêutica de Gadamer. P.A, L\&PM, 1988.
} 
fala cotidiana ${ }^{253}$. As comunicações que os sujeitos estabelecem entre si, mediadas por atos de fala, dizem respeito sempre a três mundos: 1) o mundo objetivo das coisas, 2) o mundo social das normas e instituições e 3) o mundo subjetivo das vivências e dos sentimentos. As relações com esses três mundos estão presentes, ainda que não na mesma medida, em todas as interações sociais.

Ao inserir esses conceitos no ambiente da religião começa-se a notar implicações amplas. Aquele que exerce o ministério cristão midiático deve se dar conta sobre a força da subjetividade no mundo da pessoas, também deve entender as normas da sociedade e a força das instituições, essas relações estão entrelaçadas na sociedade e muito forte no ambiente da religião.

Assim, em primeiro lugar, as pessoas, ao interagirem, coordenam suas ações. Do conhecimento que elas partilham do mundo objetivo depende o sucesso ou o insucesso de suas ações conjuntas, sendo que a violação das regras técnicas conduz ao fracasso. Em segundo lugar, as pessoas interagem orientando-se segundo normas sociais que já existem previamente ou que são produzidas durante a interação. Essas normas definem expectativas recíprocas de comportamento, sobre as quais todos os participantes têm conhecimento.

Esse tipo de ação não é avaliada pelo seu êxito, mas pelo reconhecimento intersubjetivo e pelo consenso valorativo, sendo que sua violação gera sanções.

Em terceiro lugar, em todas as interações as pessoas revelam algo de suas vivências, intenções, necessidades, de seus temores etc., de tal modo que deixam transparecer sua interioridade. Embora as pessoas, em maior ou menor grau, possam controlar as manifestações de suas vivências subjetivas, das suas ações podem-se tirar conclusões a respeito da sua veracidade.

Quadro 2 - Elementos constitutivos e constituintes do sujeito

\begin{tabular}{|l|l|l|}
\hline \multicolumn{1}{|c|}{ Matriz } & $\begin{array}{l}\text { Elementos constitutivos } \\
\text { e constituintes }\end{array}$ & $\begin{array}{l}\text { Como esse sujeito fronteiriço } \\
\text { se inscreve nesse contexto? }\end{array}$ \\
\hline \begin{tabular}{l|l} 
a) O mundo objetivo das \\
coisas
\end{tabular} & - coordenação de ações & $\begin{array}{l}\text { Via participação; } \\
\text { via consolidação da identidade; } \\
\text { via demonstração de } \\
\text { sentimentos; } \\
\text { via razão e afetividade } \\
\text { simultaneamente. }\end{array}$ \\
\hline $\begin{array}{l}\text { b) O mundo social das } \\
\text { normas e instituições }\end{array}$ & $\begin{array}{l}\text { - normas sociais } \\
\text { previamente estabelecidas }\end{array}$ \\
\hline $\begin{array}{l}\text { c) O mundo subjetivo das } \\
\text { vivências e dos } \\
\text { sentimentos }\end{array}$ & $\begin{array}{l}\text { - todas as intenções } \\
\text { revelam algo de sua } \\
\text { vivência }\end{array}$ & \\
\hline
\end{tabular}

${ }^{253}$ HORSTER, Detlef et alii. Habermas zur Einführung. Hamburg: Soak, 1988. 
Sob o estímulo do empenho político, muito forte nos anos 70 do século $\mathrm{XX}$, Habermas vê com preocupação o emergir, na Alemanha e no Ocidente, de tendências contrapostas (neoconservadoras e neoanárquicas) que rejeitam as sociedades democráticas. Nesse contexto, surge a obra Teoria do Agir Comunicativo, em 1981. Trata-se de uma obra de arquitetura complexa cujo objetivo é a formulação de uma teoria orgânica da racionalidade crítica e comunicativa; uma teoria fundada sob a dialética entre agir instrumental e agir comunicativo ou, como ele diz, entre "sistema e mundo da vida".

O sistema está vinculado ao agir instrumental; é o Estado com seu aparato e a sua organização econômica. O mundo da vida está vinculado ao agir comunicativo; é o conjunto de valores que cada um de nós individualmente ou comunitariamente "vive" de maneira imediata, espontânea e natural.

Segundo Habermas, estado e sociedade se tornaram autônomos mediante meios de controle que são o valor de troca e o poder administrativo. Foram condensados em um complexo monetário-administrativo; tornaram-se autônomos em relação ao mundo da vida estruturado comunicativamente (com esfera privada e pública); tornaram-se manifestadamente "supercomplexos".

Esta complexidade do sistema faz com que ele interfira nos mundos da vida que são ameaçados por uma colonização interna que coloca em risco a autonomia. Esta tese de Habermas clareia os limites do marxismo. Os imperativos sistêmicos intervêm em âmbitos da ação estruturados em modo comunicativo. Trata-se de questões da produção cultural da integração social e da socialização. São questões que têm pouco a ver com aqueles clássicos do marxismo (luta de classes, opressão, coisificação).

Atualmente, os imperativos da economia e da administração, transmitidos mediante o dinheiro e o poder (imperativos do sistema) penetram nos ambientes (nos mundos da vida) de tal maneira que os destroem. Esses imperativos são controlados pela mídia. O conflito principal deste tempo, nas sociedades capitalistas avançadas e democráticas, não é um conflito de classe, mas um conflito que deriva do processo em ato de "colonização" por parte do sistema em relação aos mundos da vida. A religião e o ambiente religioso, os contornos existentes a partir das ações religiosas são afetados, em questão aqueles que exercem o ministério midiático devem estar a par dessa influência e reagir de 
acordo com os princípios da palavra de Deus.

Diante desse conflito, não são utilizáveis as teorias enraizadas no velho marxismo e as recentes teorias pós-modernas e anti modernas, que rejeitam em bloco a "herança do racionalismo ocidental" com suas feições humanísticas e iluministas. Habermas olha com confiança os vários tipos de movimento que lutam em defesa dos mundos da vida para enriquecê-los e torná-los autônomos em relação às ameaças de colonização, apresentadas continuamente pelo sistema.

Ele não propõe programas políticos precisos, mas se mantém no âmbito teórico. Ele propõe uma "revisão e adequação do marxismo em relação aos problemas e conflitos do nosso tempo, que não é o de Marx e de seus sucessores.

O Professor Mario França faz uma leitura da sociedade moderna e pós$\operatorname{moderna}^{254}$ :

A sociedade pluralista se orienta por uma ampla gama de sentidos e de orientações para que o indivíduo possa construir sua biografia sem enquadrá-lo como no passado em que havia apenas uma única visão aceita e imposta pela sociedade. Aquele que exerce o ministério pastoral midiático contemporâneo precisa entender que sua mensagem não é a única. ${ }^{255}$

O cristianismo precisa entender que as sociedades exercem suas escolhas religiosas a partir de diversas variáveis, não apenas os princípios cristãos. Quando a igreja entender esse fator, ela poderá dialogar com as várias tendências, apresentando o cristianismo como verdade orientadora para o indivíduo e apresentar a salvação proposta por Jesus. Essa é a diferença do cristianismo para as outras religiões, apesar de se identificar em outros aspectos, pois a questão da salvação é uma marca única do cristianismo, só Jesus salva, liberta o indivíduo do egoísmo e lhe conceda a possibilidade da vida eterna.

Presencia-se na atualidade na América Latina sociedades construídas a partir dos princípios cristãos, portanto a transformação é um fator que pode-se chamar de desenraizamento da fé cristã. No entanto, a transmissão da fé cristã já não ocorre de forma convencional. Na sociedade pós-moderana as crianças e os jovens recebem muito mais informação através dos meios de comunicação social - como a televisão e as redes sociais - do que de suas famílias e escolas e também

\footnotetext{
254 MIRANDA, M. F. Igreja e Estado democrático na sociedade secularizado. In: Revista Eclesiástica Brasileira. Vol. 71. Fasc. 283. Julho de 2011. p. 548-576.

${ }^{255}$ MIRANDA, M. F. Igreja e Estado democrático na sociedade secularizado. In: Revista Eclesiástica Brasileira. Vol. 71. Fasc. 283. Julho de 2011. p. 548-576.
} 
das igrejas.

É necessário compreender que uma sociedade aberta pode ainda transmitir sem maior dificuldade, pelo menos durante algum tempo, uma vaga adesão ao cristianismo. Em outras palavras, o desenraizamento não significa que se passe automaticamente do cristianismo para a incredulidade.

Mas há um problema a ser enfrentado: um cristianismo apenas nominal. Em outras palavras, a adesão ao cristianismo dentro de uma sociedade aberta não significa que o indivíduo assimilou os ensinos cristãos. O ambiente já não cria ou substitui a convicção pessoal. Essa é uma explicação para a religiosidade sem transformação da pessoa, o cidadão gosta da religião e até se identifica com alguns aspectos, esse seu interesse não gera ações nem atitudes de mudança e comprometimento.

No mundo pós-moderno, com suas descobertas e o avanço da tecnologia, surgem novos desafios que precisam ser enfrentados a luz da globalização. A vida social atual tem nas suas estruturas sinais de instabilidade e os valores morais são frágeis, as instâncias políticas têm se enfraquecido, os fatores econômicos têm sido afetados por um consumismo desequilibrado. Além de tudo isso, há o crescimento da religião islâmica, com suas características próprias.

Essas transformações socioculturais afetam a todos, como também as estruturas da sociedade, assim como a igreja, porque os membros das igrejas fazem parte dessa sociedade. É na sociedade que os cristãos vivem a realidade da sua fé e proclamar as verdades da palavra de Deus. No ambiente em que o egoísmo impera, onde a cultura dominante se impõe sobre cristianismo, é nesse contexto o cristão precisa manter a sua fé.

As transformações históricas das sociedades exigem um reposicionamento dos cristãos. Isso tem sido assim no decorrer dos tempos, sempre que a igreja foi afrontada, ela precisou se posicionar; a igreja passa a ser igreja quando ela precisa demonstrar sua essência. Quando ela pactua com a sociedade e se identifica com suas estruturas dominantes, perde sua força e deixa de cumprir seu propósito no mundo.

O cristianismo tem como princípios fazer os enfrentamentos necessários, abordar temas novos, (como aborto, manipulação genética, eutanásia), também existe a intransigência e a intolerância religiosa, a influência de sistemas de pensamento (não religiosos) que acabam repercutindo no ambiente da igreja. $\mathrm{O}$ 
cristão não pode aderir a neutralidade cabe a ele exercer sua identidade como portador da palavra, vivendo num ambiente comunitário.

$\mathrm{Na}$ relação com o estado, cabe ao cristão levar em conta o que diz o filósofo Habermas: Pois a participação de todos no processo democrático garante uma elaboração jurídica que respeita tanto os direitos fundamentais liberais como políticos. Deste modo o poder estatal é todo afetado pelo direito, que não deixa lacunas a serem preenchidas por elementos pré-jurídicos". 256

De certa forma, o Estado deve funcionar com a participação de todos, numa discussão racional, mesmo que não se possa prever o seu resultado. A livre escolha se faz evidente e o cidadão deverá participar do estado podendo exercer sua fé com liberdade.

Um dos desafios para um estado secularizado é desenvolver o dialogo-interreligioso, num ambiente plural as diversas opiniões e posicionamentos da religião precisam ser interpretados pelo estado de maneira que o cidadão tenha liberdade de expressar e viver suas crenças.

Naturalmente, o Estado não pode ficar indiferente diante de uma tradição religiosa que questione seus princípios básicos. Mas pode se dar por satisfeito se a mesma não atentar contra sua ordem jurídica fundamental, mesmo mantendo uma "reserva interior" com relação à ordem vigente.

A liberdade religiosa, reconhecida pelo Estado, não pode confinar a religião à esfera da vida privada, já que seus membros não só a professam e expressam, mas também procuram vivê-la socialmente através de atitudes e comportamentos específicos. Não se pode exigir do adepto de uma religião, que fundamenta a própria existência em suas convicções religiosas, que renuncie às mesmas sempre que estiver lidando com a esfera pública, como se ele devesse buscar suas convicções de outra fonte não religiosa.

O cristão vive e exerce seus direitos no Estado, o Estado existe pela formação dos cidadãos, incluindo aqueles que exercem a fé cristã. Assim sendo, a igreja sempre exercerá influência no Estado; a neutralidade da igreja pode deixar o Estado sem direção. Os servos de Deus têm a tarefa de apontar os caminhos a serem trilhados pela sociedade, principalmente relacionados aos princípios cristãos.

\footnotetext{
${ }^{256}$ HABERMAS, Jurgen. LUHLWR H GHPRFUDFLD - Entre faticidade e validade. Rio de Janeiro: Tempo, 1997. p. 38.
} 
A igreja deve exercer um papel de referência na sociedade, no diálogo com Bento XVI, Habermas reconhece que a fé cristã é sensível ao destino dos últimos da sociedade, dos fracassados, dos sofridos, oferecendo-lhes uma salvação definitiva e fortalecendo sua esperança. Além disso, reafirma a força inspiradora e mobilizadora da religião, não só funcionalmente, mas substantivamente, por seus próprios conteúdos religiosos. Todos os cidadãos, cristãos ou não, devem promover e defender a base da vida social, a justiça, a liberdade, o respeito à vida e os direitos da pessoa.

A tarefa política do cristão deve ser objetiva e intencional, ele tem o dever de apresentar um programa bem determinado, alianças táticas, bem como os meios à disposição. Vive-se hoje numa sociedade pluralista na qual a diversidade dos campos do saber, dos valores culturais, das experiências de vida, dos objetivos imediatos, da formação recebida, das crenças religiosas, das faixas etárias, das classes sociais, provoca uma inevitável pluralidade de percepções inclusive das ações políticas a serem realizadas.

Esta diversidade também é encontrada entre os cristãos, sendo que a mensagem bíblica, atuando como inspiração, motivação, e orientação para a ação política, pretende fornecer opções concretas que não ignorem o contexto social. Com isto se evita um sobrenaturalismo que pretende deduzir de forma mecânica a mensagem do Evangelho com ações concretas para a atuação política, evitando o "evangelismo político" que se esquece que a fé cristã não pode se identificar com opção alguma política.

A Igreja, por sua vez, deve respeitar sua essência de comunidade cristã com suas doutrinas e padrões éticos. Pois também em seu interior se depara com a pluralidade de experiências, de formações, de teologias, de preocupações, de leituras da realidade que, mesmo com respeito à Palavra de Deus e à doutrina do evangelho, podem avaliar diversamente e, por conseguinte, querer agir de forma diferente diante de uma situação determinada.

Como afirma o Concílio Vaticano II com relação à ação dos cristãos na sociedade: Se depois as soluções apresentadas, mesmo sem intenção das partes, são facilmente ligadas por muitos à mensagem evangélica, é preciso se lembrar de que não é lícito a ninguém, nos casos citados, reivindicar exclusivamente para sua sentença a autoridade da Igreja. Mas procurem, em diálogo sincero, esclarecer-se 
reciprocamente, conservando a caridade mútua e preocupados em primeiro lugar com o bem comum. ${ }^{257}$

A igreja é a forma de Deus agir na sociedade; com a participação da igreja Deus está agindo. Quando a igreja intervém, a ação de Deus se consolida; quando a igreja ajuda as pessoas, a bondade de Deus está sendo exercida. Apesar da tecnologia, apesar dos novos desafios, a igreja deve continuar a mesma em essência; pode-se dizer que as estratégias são novas, mas o conteúdo deve ser o mesmo.

Nesse contexto e a partir dessa análise, a igreja precisa ensinar e apregoar a respeito da experiência pessoal com Jesus. Essas experiências com Deus, com Jesus e com o Espírito Santo se constroem a partir de momentos em que o indivíduo experimenta o sentido de tais percepções que o levam a ultrapassar a si mesmo. Quando Deus entra na vida da pessoa, ela passa a perceber a realidade de si mesmo que só a experiência cristã pode proporcionar.

\subsection{Desafios para o ministério cristão midiático}

Tendo em vista o desenvolvimento do modo de vida atual, deve-se levar em conta os fundamentos do ministério cristão para que possa ser uma opção de serviço e anúncio da mensagem de Jesus. O ministério cristão foi instituído por Deus. Através de um chamado sobrenatural, Ele vocacionou homens e mulheres para o serviço, pessoas com um dom especial para cuidar de outros e ajudar as pessoas a encontrarem o caminho da salvação. Cabe a essas pessoas servirem de referência e, ao mesmo tempo, contribuírem por meio de seu exemplo para que a sociedade seja harmônica e amorosa.

Esta vocação apostólico-pastoral se mostra claramente ao longo do N.T. A igreja é enviada a buscar, sob a direção do Espírito, as outras ovelhas do aprisco (Jo.10:14$17 ; 20: 21-23 ; 21: 15-17)$. É constituída sal da terra e, portanto, enviada a dar sabor e preservar. É agente de reconciliação (2 Co.5:19,20; 6:1). É comunidade sacerdotal (Heb.13:15,16; 1 Pe. 2:5) e profética (1 pe. 2:9,10, chamada a ser um testemunho vivo das virtudes de Deus e comprometer-se com os que sofrem. (Tiago 1:26,27; Lc.10:25. $)^{258}$

\footnotetext{
${ }^{257}$ Pastoral, Constitución. "Gaudium et Spes." Compêndio do Vaticano II (1966).

${ }^{258}$ COSTA, Orlando E. Evangelizacíon contextual, fundamentos teológicos e pastorais. San José: Ed. Sebila, 1986. p. 91.
} 
É necessário criar instrumentos de conscientização dos princípios cristãos e do modo de vida em Cristo que ajudem a propagar o cristianismo. Desde os anúncios em peças publicitárias até a pregação nos púlpitos, a proposta cristã dever ser apresentada com clareza e com objetividade. O discurso deve ser coerente, apresentando o fato de que é possível viver uma vida honesta, sincera e franca, mesmo em algum contexto social em que não se favoreça a prática da honestidade.

A questão fundamental do evangelho é a fé, a crença de que que o evangelho que faz diferença na vida das pessoas e fundamental para todos, esse encontro do evangelho que te ajuda a viver, e fundamento para entender o teu jeito de se posicionar na sociedade, a grande pergunta e desenvolver um ministério pastoral comunitário, esse evangelho tem uma dimensão, bíblica quando uma dimensão comunitária publica, ele gera uma vida que faca diferença, se expressa em comunidade mas tem uma dimensão, quais são as peças que a gente junta no ministério pastoral, uma boa formação, ele precisa espiritualidade e precisa de testemunho público e boa gestão, nossa igrejas se tornam grandes e nesse fato se tornam vítimas do mercado, precisa ser desenvolvida uma resistência ao mercado. Essa formação e uma espiritualidade sólida e que vai fortalecer seu testemunho. O testemunho do evangelho tem pouco de uma ética pública, tem muito mais do mesmo, ele precisa vencer o mercado, a gestão vai te ajudar a vencer o equilíbrio, o ministério pastoral hoje é complexo, não se pode ceder ao mercado e a cultura, e não se pode perder a relevância, cada geração precisa enfrentar seus desafios. ${ }^{259}$

Alguns chegam a afirmar que é mais fácil viver uma vida desonesta do que praticar a honestidade. Existe uma forte tendência de transferir o problema: "A culpa é do outro", todos são culpados de uma forma ou de outra pelos desatinos existenciais dessa caminhada.

Miséria, analfabetismo, criminalidade urbana, crianças de rua, nada disso é responsabilidade do cidadão. A culpa é dos corruptos, dos incapazes do governo, dos bandidos, do sindico ou do vizinho antipático. Em épocas de seca, puxam-lhes as orelhas e acusam-nos de irresponsáveis. A proliferação de informações, a pluralidade de padrões sexuais e sentimentais, a insegurança profissional, a relativização das verdades morais e, enfim, a fragilidade das instituições formadoras de identidades desorientam os indivíduos. ${ }^{260}$

O sujeito pós-moderno, vive um tipo de fuga de si mesmo, e nessa "corrida"

\footnotetext{
${ }^{259}$ Entrevistas, Apêndice 1, S1, 2016, p. 208.

${ }^{260}$ COSTA, Freire Jurandir. Campeonato de irrelevâncias. Folha de São Paulo, Caderno Mais, junho 2001, p. 4.
} 
desenfreada, acaba seguindo os acontecimentos televisivos que desembocam na religião, que ele mesmo não sabe quais serão os resultados finais. É preciso mudar esse quadro. Um dos caminhos para a libertação é um ministério pastoral efetivo, contextualizado e relevante na sua ação, que esteja comprometido em ajudar as pessoas.

De acordo com dados levantados por Boff e que refletem um pouco dessa realidade, no caso do Brasil, $75 \%$ da população que vive em situação de marginalidade relativa; $43 \%$ da população condenada a sobreviver apenas com um salário mínimo.

Não é de admirar que $40 \%$ dos brasileiros vivam, trabalhem e durmam com fome crônica; que haja 10 milhões de deficientes mentais, 8 milhões atacados de esquistossomose, 6 milhões com malária, 650 mil são tuberculosos e 25 mil leprosos. $^{261}$

Apesar de já ter passado tempo desde que essa pesquisa foi realizada, se for feito um levantamento atual, os dados coletados serão mais ou menos semelhantes. No meio desta situação: Não nos faltam vontade e determinação; faltam-nos grandeza de objetivos que espelhem o tamanho de nosso poder de agir e iniciar o novo. De tanto querer pouco acabamos por medir o esforço da busca pela insignificância do que é buscado. Usa-se a potência da vontade humana para atingir propósitos mesquinhos, assim como o insensato que resolvesse acender holofotes para procurar alfinetes na escuridão. ${ }^{262}$

"Temos metas, bem aquém de nosso poder de criar." ${ }^{263}$ Pode-se até dizer que nos acostumamos com nossa pequenez, nos enquadramos de acordo com as orientações do mercado.

É preciso uma postura ministerial abrangente e relevante, que ajude o indivíduo a desenvolver suas capacidades de criar, a ter esperança neste contexto desesperançado, a criar e propor objetivos e propósitos claros e definidos, como ampla deve ser a fé de um cristão.

Um exemplo: O papa Francisco não pediu, estava quieto em Buenos Aires, andando de guarda chuva e de metrô, gostava de andar no meio do povo, tinha um

\footnotetext{
${ }^{261}$ BOFF, Leonardo. Igreja: Carisma e Poder. Rio de Janeiro: Editora Vozes, 1982. p. 71. ${ }^{262}$ ALMEIDA, Fernando José de. O educador: magnanimidades e ambiguidades. São Paulo em Perspectiva, v. 15, n.2, 2001, p. 92-95.

${ }^{263}$ COSTA, Freire Jurandir. Campeonato de irrelevâncias. Folha de São Paulo, Caderno Mais, junho 2001, p. 4.
} 
carro muito simples, sempre escolheu ser pobre, quando o fizeram papa, por conselho do Dom Cláudio de São Paulo, um jesuíta e um franciscano, qual o nome devo dar para o Papa, o seu nome deve ser Francisco, você é pobre igual a Francisco, ele disse é mesmo, eu vou chamar Francisco, influência de um cardeal franciscano, e um jesuíta, é um modelo de misericórdia, se mistura com os pobres quer dialogo com todas as religiões, vai para o meio do povo, Ele escreveu o livro o nome de Deus é compaixão, estão se escrevendo muito sobre perdão, compaixão e misericórdia, estamos reinaugurando a era da compaixão, todas as igrejas estão buscando juntas, se existe uma prova que o ecumenismo pode funcionar é a compaixão. Se lutarmos contra a violência estava trilhando um novo caminho para o evangelho, a meu ver e a nova era da compaixão. ${ }^{264}$

Quando se diz que a diferença será feita através do "ministério pastoral" (O agir de Deus no mundo, modelado em Cristo Jesus), pressupõe-se que não se pode depender das estruturas governamentais ou até mesmo religiosas para mudar este quadro catastrófico da sociedade.

Escobar $^{265}$ afirma que na formação ministerial para latino americanos do futuro não basta simplesmente imitar e traduzir as metodologias forjadas em países ricos com seu triunfalismo e sua dependência de técnicas de mercado e persuasão.

A partir deste diagnóstico, deve-se desenvolver um ministério que consiga fazer uma leitura de seu tempo e do que tem acontecido no decorrer da história, e que sejam fatores relevantes para ações ministeriais transformadoras. Não há futuro nem presente para aqueles que desconhecem o seu passado, não levam em conta os ensinos da palavra de Deus.

Não se pode espiritualizar o que não é espiritual, não se pode trocar os ensinos do reino de Deus por planos humanos e egoístas, mas é preciso avaliar e descobrir que os princípios Divinos são coerentes com a existência humana. Os planos de Deus são aplicáveis e cabíveis em qualquer sociedade.

Durkhein encaminha-se neste sentido, mas sem tirar quaisquer conclusões, pois seu objetivo não é esse quando quer distinguir as "religiões primitivas" das "religiões complexas" caracterizadas pelo "choque das teologias, as variações dos rituais, a multiplicidades dos grupos, a diversidade dos indivíduos".

Numa sociedade complexa, a Igreja deve se "complexificar" internamente. "Complexidade indica que na sociedade contemporânea se reduziu pela necessidade ou pelo costume, e que, do outro lado, se amplia um espaço de

\footnotetext{
${ }^{264}$ Entrevistas, Apêndice 2, S4, 2016, p. 228.

${ }^{265}$ ESCOBAR,Samuel, Mission in Latin America: An Evangelical Perspective,Missiology, 1992.p 244.
} 
indeterminação, ou seja, de liberdade, [...] há também a disponibilidade para a vida social de mais instrumentos de intervenção face aos desafios do ambiente, físico ou humano, que se torna sempre mais heterogeneamente relativo em relação aos sistemas sociais. Complexidade é também crescimento de autonomias internas na organização social. ${ }^{266}$

Por sua vez, os teólogos propõem que a Igreja adote um modelo "sinodal", entendendo que com isso um modo de organização em que diversos tipos de comunidades, grupos, movimentos caminham juntos e, embora conservando a sua fisionomia própria, encontram-se periodicamente para manifestar a recíproca comunhão em Cisto e reforçar a solidariedade de uns com os outros. ${ }^{267}$ Em tese, essa estrutura é fascinante, mas na prática não se pode, de forma nenhuma, descaracterizar a igreja por questões culturais; a adoração supera essas diferenças.

Frente a um sofrimento que continua existindo, intervém uma emoção - a emoção do consolo que entra numa estrutura narrativa coletiva. O consolo apazigua, não dá qualquer meio para curar senão o sentimento de viver dignamente, porque se tem o seu lugar na história bíblica. Emoção experimentada mesmo que apenas nesses poucos instantes. Participa-se assiduamente aos cultos para obtê-la. Às vezes esta emoção dá a ideia de que a dignidade também pode ser encontrada lá fora: em casa, na rua. Mas não é uma ilusão para os demais pobres, os mais abandonados, os mais desfavorecidos? $?^{268}$

Um ministério pastoral midiático significativo deve levar em conta essas questões, pois precisa ser a expressão de uma compreensão da fé e da Igreja no contexto pluralista e diversificado da realidade de hoje. Deve-se partir do entusiasmo pela missão, de uma "consciência missionária" viva, mas também deve ter seu momento de racionalidade para organizar as ações frente à complexidade dos desafios do mundo e a compreensão da Igreja que influenciam novas formas de atuação como Igreja na sociedade e o ministério pastoral. ${ }^{269}$

Um ministério pastoral midiático que consiga fazer essa leitura, e que seja contextualizado ao ponto de propor um culto e uma participação comunitária simultânea, que seja significativo e que se torne uma ferramenta para estabelecimento do reino de Deus, não pode se perder, exercendo uma função

\footnotetext{
${ }^{266}$ ALBERTO, A. A presença da Igreja na cidade. Rio de Janeiro: Vozes, 1994. p. 95.

${ }^{267}$ ALBERTO, A. A presença da Igreja na cidade. Rio de Janeiro: Vozes, 1994. p. 105

${ }^{268}$ CORTEN, André. Os Pobres e o Espírito Santo: O Pentecostalismo no Brasil. Rio de Janeiro: Vozes, 1996. p. 77.

${ }^{269}$ ALBERTO, A. A presença da Igreja na cidade. Rio de Janeiro: Vozes, 1994. p. 105.
} 
apenas cultualista, ritualista e conformista. Precisa, sim, participar ativamente do modo de vida das pessoas, ter uma ação comunitária e apresentar propostas para a sociedade, que sejam permeadas pelos princípios do reino de Deus.

Eu sou pároco, coordeno uma paróquia e uma capela, tenho um instituto e sou o vice-presidente, de uma organização Amigos da Fé, organização com cunho pedagógico, cuida de crianças que são filhos de pais portadores de vírus HIV, estamos atingindo outras realidades, como creches e alfabetização de crianças, as minhas atividades na área de comunicação tem ajudado no desenvolvimento dos projetos, favela da fumaça , favela do pantanal, tem um marco de violência. Eu não sou um padre de uma grande cidade apenas. Minha experiência vem das CEBS, a própria teologia da libertação, e a renovação carismática católica, tenho as ações sociais, mais de duas mil famílias atendidas, o conselho tutelar que atua junto a paróquia e a pastoral da criança, e a dimensão do samaritano com cestas básicas. ${ }^{270}$

Uma ação do ministério pastoral midiático bem articulada tem a chance de ser eficiente quando desemboca num programa social, nesse caso, um programa de pastoral na cidade ou pastoral urbana. As diretrizes indicam que uma organização pastoral eficaz deve atender aos vários níveis em que a vida das pessoas e das comunidades se desenvolve.

A realidade urbana atual exige, em primeiro lugar, que se preste atenção à emergência da situação e que se valorize a participação da pessoa. Para isso, a ação pastoral deve estar atenta à experiência religiosa subjetiva dos fiéis, ao primado da consciência, e a ligação entre fé e vida quotidiana. Para exemplificar: o desafio é fazer da família cristã um lugar de "personalização" da iniciação à fé cristã, em sintonia com a comunidade eclesial, gerada pela experiência da fé.

Num segundo momento, há o desafio de gerar novas formas comunitárias de vida cristã, que sejam adequadas ao contexto urbano plural, tanto numa base cultural quanto na religiosa. Nesse aspecto, é preciso buscar respostas novas que fujam da polarização. Nem a diversidade anárquica, nem a uniformidade monótona são normas para isso. O caminho é achar um ponto de equilíbrio entre os ensinamentos teológicos e as práticas cristãs atuais.

A questão fundamental e a questão do evangelho, a fé, a crença de que o evangelho faz diferença na vida das pessoas é fundamental para todos, esse encontro do evangelho que te ajuda a viver, é importante para entender o teu jeito de se posicionar na sociedade, a pergunta é como desenvolver um ministério pastoral comunitário, esse evangelho tem uma dimensão, bíblica quando uma dimensão comunitária publica, ele gera uma vida que faca diferença, se expressa

${ }^{270}$ Apêndice 1, Entrevistas, S3, 2016, p. 204 
em comunidade mas tem uma dimensão bíblica, quais são as pecas que a gente junta no ministério pastoral, ele precisa espiritualidade e precisa de testemunho público e boa gestão, nossa igrejas se tornam grandes e nesse fato se tornam vítimas do mercado, precisa ser desenvolvida uma resistência ao mercado. Essa formação e uma espiritualidade solida é que vai consolidar seu testemunho. O testemunho do evangelho tem pouco de uma ética pública, tem muito mais do mesmo, ele precisa vencer o mercado, a gestão vai te ajudar a encontrar o equilíbrio, o ministério pastoral hoje é complexo, não se pode ceder ao mercado e a cultura e não se pode perder a relevância, cada geração precisa enfrentar seus desafios. ${ }^{271}$

Há elementos objetivos e subjetivos que devem orientar a ação do ministério pastoral, sem excluir as pessoas e os grupos, mas ser capaz de manter uma coerência básica com as opções de fundo da Igreja particular. Basta lembrar, como exemplo, a exigência de renovação da paróquia da pastoral sacramental, da relação agente de pastoral e comunidade, pároco e fiéis etc.

Num terceiro aspecto, o desafio da Igreja é se tornar visível na sociedade, ou seja, articular uma presença pública da igreja perante o povo, não mais nos moldes da cristandade, que era baseada na tutela da sociedade, na relação ambígua com o poder, mas decididamente baseada no testemunho profético de que ela é capaz e pela sua radicação no Evangelho de Jesus Cristo. Dessa forma, a articulação pastoral midiática cumprirá seu papel: que a igreja, como comunidade viva, deve ser reconhecida como sinal do Reino de Deus. Noutros termos: a articulação pastoral como expressão institucional da Igreja está a serviço da Igreja enquanto acontecimento libertador, gerador de vida e esperança para a sociedade. $^{272}$

Essa atuação deve ser exercida através do serviço, Jesus é o modelo para o exercício do poder, o modelo do poder serviço representado no lava-pés, tem dimensões comportamentais humanas, se Jesus é o modelo, o fator galileia ${ }^{273}$, por

${ }^{271}$ Apêndice 1, Entrevistas, S1, 2016, p. 198.

${ }^{272}$ CALIMAN, Cleto; PINHEIRO, J. Ernanne (Orgs.). O evangelho nas culturas. América Latina em missão. $5^{\circ}$ Congresso Missionário Latino-americano - COMLA 5. Petrópolis: Vozes, 1996. p.108 e 110.

${ }^{273}$ Deixamos com Josefo (Guerra Judaica 3,41-42) profundo conhecedor da Região por causa das suas campanhas militares a apresentação do lugar: Há duas Galileias, uma chama-se a alta e a outra a baixa, ambas são limitadas pela Fenícia e Síria. Do lado do ocidente estão as cidades de Tolemaida, todo o seu território e o Monte Carmelo, que outrora pertencia aos galileus e agora é dos tírios, perto do qual está a cidade de Gamala, chamada a cidade dos cavaleiros, porque o rei Herodes para lá mandava os dispensados. Do lado do Sul tem, na fronteira, a Samaria e Citópolis, até o Rio Jordão. Do lado do oriente os seus limites são Hipom, Gadaris e Galaunita, que são também os do reino de Agripa. E do lado do norte confinam com Tiro e seus territórios. O povo galileu, embora estas duas províncias estejam rodeadas de tantas e diversas nações, todavia elas sempre lhe resistiram em todas as suas guerras, porque além de serem instruídos desde a infância na arte da guerra. As terras são férteis e tão bem plantadas com todas as espécies de arvores, que 
onde Jesus andou, com quem Jesus andou, contato com as crianças, com o pobre, sua decisão de ir para Jerusalém para morrer, é o poder do serviço, fundamentalmente e o poder do amor, o poder religioso, deve ser exercido com amor que te leva para o serviço que é sacrificial, serviço ao pobre e a mulher sofrida, ao estrangeiro. A teologia sendo analisada do ponto de vista da vítima, não do conquistador. Uma das vertentes do movimento de Laussane é a vida simples, encarnação, viver de forma consistente servindo, não vive o poder do comercio nem do palácio, mas da simplicidade, do abraço e do serviço. ${ }^{274}$

É pertinente considerar que a modernidade pensa o ser humano a partir da liberdade, como autor de seu próprio destino. O homem, já dizia Humboldt, apreende sobre os objetos principalmente, assim, poder-se-ia dizer que seus sentimentos e ações dependem de suas percepções e da forma como a linguagem os apresenta.

Segundo o mesmo processo pelo qual cada ser humano desfia a linguagem para fora de seu próprio ser, acaba por se confundir com ela; cada linguagem desenha um círculo mágico em torno do povo a que pertence, um círculo que não se pode sair sem saltar para dentro de outro. Esta teoria da linguagem como modo de conhecimento que Bourdier estendeu a todas as "formas simbólicas" e, em particular, aos símbolos do rito e do mito, quer dizer, a religião concebida como linguagem, aplica-se também e, sobretudo, às teorias da religião como instrumentos de construção de fatos científicos. ${ }^{275}$

A partir de sua autonomia, o ser humano precisa ser orientado por princípios que o ajudem a ser uma pessoa melhor. A partir dessa compreensão, o ministério cristão midiático pode ser uma alternativa de ajuda para o cidadão e também para a sociedade em geral. Devido ao seu alcance e dinâmica multimídia e com uma mensagem transformadora, interessante e dinâmica que desperte interesse para os indivíduos, pode ajudar muitas pessoas em todos os locais em que seja possível acesso..

sua abundância convida a cultivá-las mesmo aqueles que têm pouca inclinação para a lavoura e não há terras inutilizadas. Não somente há uma grande quantidade de aldeias e vilas, mas também grande número de cidades, tão populosas que a menor delas tem mais de quinze mil habitantes. ANDRE, L. Judaísmo, Cristianismo e Helenismo, São Paulo, Editora Fapesp, 2007. p. 172.

${ }^{274}$ Apêndice 1, Entrevistas S1, 2016, p,198

${ }^{275}$ PIERRE, B. A economia das trocas simbólicas. São Paulo: Perspectiva. 1987. p. 27. 


\subsection{Repensando o ministério midiático cristão}

Para que esta tese pudesse ser desenvolvida de forma atual e respondesse à pergunta “ ministério midiático está atendendo as necessidades das pessoas?" foi desenvolvida uma pesquisa baseada em entrevistas com quatro líderes midiáticos. Assim, foram entrevistados dois padres católicos e dois pastores protestantes, todos com grande impacto na mídia e com alcance de milhões de pessoas através de seus programas de rádio, televisão, escrita de livros, revistas, jornais, como também uso das redes sociais. A partir dessas entrevistas, serão apresentadas algumas questões que foram destacadas e que se espera que possam servir de referência para aqueles que exercem o ministério mediático ou para aqueles que pretendem participar de tão sublime tarefa.

Em primeiro lugar, o ministério cristão precisa ser repensado. Deve-se seguir um modelo que focalize a comunidade e não os indivíduos isolados e, além disso, é preciso anular o "estrelismo" (a vontade de brilhar e de aparecer a partir dos modelos religiosos), dando lugar a uma pastoral midiática que preze pelo serviço e pelos cuidados para com as pessoas. A verdade perturbadora sobre os modelos pastorais contemporâneos é que, em grande parte, não podem ser reproduzidos.

O ministério midiático deve ser resposta a uma vocação:

Acredito por causa da vocação, tem a ver com o mistério do chamado de Deus, a experiência de que Deus estava me chamando, essa experiência, determinou minha vida, essa experiência de vocação, saber ser colocado no mundo a partir daquilo que Deus tem para mim. Eu acredito na minha vocação e quero ser uma pessoa sensível a realidade humana, principalmente a necessidade de escutar o gemido humano, quanto mais santo mais humano, o ser humano carece desse evangelho, esse encontro com o evangelho torna a pessoa mais humana. A vocação e o serviço ao outro. ${ }^{276}$

Aqueles que são chamados e vocacionados tem a responsabilidade de cumprir com a vocação, mas estar dispostos a obedecer às ordens de seu Mestre. Cabe a eles entenderem as implicações dessa nobre tarefa, estar conscientes de seu papel no mundo e, de certa forma, buscar o preparo necessário para atuar de forma relevante e atender o clamor daqueles que sofrem. Nesse caso, se a mídia é uma alternativa de serviço eficaz, e faz-se uso dela de forma adequada, não se

${ }^{276}$ Apêndice 1, Entrevistas S1, 2016, p. 198. 
pode perder a essência do evangelho na sua apresentação.

No ponto de vista teológico vive-se em vantagens e desvantagens, cidadão do reino dos céus e do reino encarnado. Cada tempo e cada época precisa fazer essa leitura, é um período de anjos e demônios, nesse sentido não se demoniza o mundo de hoje e santifica o mundo de ontem. Tem desafios que precisam ser respondidos com as ferramentas de nossa época e não com o instrumental de ontem. Não adianta apenas dizer que se vive em uma sociedade liquida, precisamos aprender a se comunicar com essa sociedade. Precisamos aprender a nos comunicar no padrão do twitter. Qual seria o critério fundamental para isso, o que é que impede de anunciar o evangelho na sua totalidade para o público que você quer conversar, você tem espaço para o anuncio do evangelho na sua totalidade, se a tua mídia te permite falar do evangelho. O vídeo tem limitações para o anuncio do evangelho mais integral, precisa entrar numa análise mais profunda, sobre que tipo de mídia nós estamos falando, e como essa mídia nos ajudará na pregação do evangelho na dimensão profética, a mídia comercial, você converte o evangelho a mídia que você usa, nenhuma mídia e neutra nem ontem e nem hoje. ${ }^{277}$

Os vocacionados precisam desenvolver essa formação e esse entendimento de que a mídia é apenas uma ferramenta para comunicar o evangelho de Jesus Cristo, e que não se deve usar a mídia como um fim em si mesmo. Por sua vez, essas alternativas midiáticas são neutras em si, o que indica que uma abordagem para o bem ou para o mal é relevada pelo conteúdo veiculado por aquele que exerce determinada tarefa. $\mathrm{O}$ ministério midiático deve ser exercido para o bem e por pessoas do bem. Infelizmente, o contrário também é possível.

O poder religioso precisa influenciar a mídia apresentando pautas para uma agenda não contraditória. A mídia é como o quarto poder, a mídia não é neutra, ela precisa ser descortinada, precisa revelar a serviço de quem ela está. O evangelho diz para a mídia a serviço de quem ela está, porque a essência do Evangelho é verdade e justiça. A mídia precisa ser denunciada quando está a serviço da exploração e da riqueza, basicamente o poder religioso, precisa denunciar e precisa conseguir anunciar o evangelho para a necessidade de uma sociedade justa, onde a verdade seja importante, onde o pobre seja protegido, o evangelho precisa ajudar a mídia a ter esse olhar. A mentira prevalece na sociedade atual, a mentira e um componente político atual, o evangelho deve ajudar a mídia a vencer a mentira e proclamar a justiça e a verdade. ${ }^{278}$

Aquele que exerce o ministério midiático deve estar consciente de que a mídia precisa ser pautada com os temas do evangelho. Assim, as oportunidades que surgirem de participação no ambiente midiático devem ser aproveitadas de tal maneira que apresentem os princípios da verdade e da justiça. O evangelho de

\footnotetext{
${ }^{277}$ Apêndice 1, Entrevistas, S1, 2016, p. 191.

${ }^{278}$ Apêndice 1, Entrevistas, S1, 2016, p. 197.
} 
Jesus Cristo é uma defesa para o pobre e para aquele que sofre, e através dessa ferramenta de grande impacto que consegue se comunicar com toda a sociedade, pode-se apresentar os temas relacionados ao evangelho, as boas notícias a respeito da salvação, o cuidado do pobre, da viúva, da criança e do estrangeiro. Pode-se se pensar em uma alternativa para que haja maior alcance para comunicar as boas notícias da parte de Deus.

No decorrer das entrevistas, percebeu-se que os entrevistados valorizam a importância da formação pastoral e teológica para o desempenho das tarefas do ministério midiático, o qual não pode ser desenvolvido apenas de maneira intuitiva e ingênua, mas exige capacitação adequada para o exercício dessa tarefa.

Parece que existe um esforço muito grande das lideranças religiosas, de formar melhor os padres e pastores, hoje há muita gente que estuda a comunicação direito, sociologia e psicologia. Pregadores que estão estudando muito, mas é preciso acentuar mais ainda a formação do pregador, há os que improvisam demais, os novos avivalistas que aparecem do nada que brincam de pregação. Há muitos pregadores despreparados vão encantados com o seu visual, valorizam demais aparecer na televisão e não falam em nome de suas igrejas, há muito individualismo, assumem a mídia como se fosse deles o microfone e não da sua igreja, ocupam o tempo todo quando há outros que também poderiam falar, há muitos que ocupam de oito a dez horas por dia de televisão, minha crítica às igrejas não estão conseguindo controlar seu pregadores famosos. ${ }^{279}$

O preparo para o exercício da tarefa é fundamental e percebe-se a abrangência dos estudos, ou seja, o indivíduo deve ter uma qualificação ampla, para que possa comunicar-se de maneira eficaz, evitando deter-se em um determinado assunto apenas. Seu trabalho é intenso e suas leituras devem ser múltiplas. A seguir é apresentada a rotina de trabalho de um dos entrevistados para que possa servir de referência a respeito da dedicação e o aprimoramento para tão sublime tarefa.

Por quarenta e cinco anos levantava às cinco e meia e deitava à meia noite, muito trabalho, cheguei a dar oito conferências por dia, fiquei doente, tive um AVC, diabetes, tive que diminuir bastante, recuperei a fala, recuperei do diabete e o câncer que foi controlado, hoje levanto pelas seis e meia, pesquiso, estudo, escrevo, três a quatro horas de pesquisa por dia, escrevo muito e leio muito sobre ecumenismo, psicologia, pedagogia, história, sociologia e comunicação, a partir dessas áreas escrevo meus livros. Não vou à televisão, eles vêm a mim, dou muitas entrevistas, moro em São Paulo e Taubaté, assessoro padres que estudam comunicação, meu cotidiano é ensinar, pesquisar e escrever, também fazer rádio, rádio gravado, e mando para mais de cinquenta emissoras, que retransmitem.

${ }^{279}$ Apêndice 1, Entrevistas, S4, 2016, p. 214. 
Programas curtos de cinco a dez minutos por programa. ${ }^{280}$

O trabalho é intenso e a dedicação deve ser séria para exercer o ministério midiático; não pode ser uma ação intuitiva de pessoas que querem se promover através do rádio, televisão e das redes sociais. Aqueles que exercem essa tarefa devem estar conscientes dessa oportunidade que não deve ser usada para vantagens pessoais ou para promoção individual. A tarefa é extenuante e exige muita disciplina e organização pessoal para poder exercer o serviço com excelência.

Um caos organizado, tenho uma agenda básica, que tento seguir, trabalho muito na igreja, dou expediente, preparo sermão, segunda-feira, é um dia administrativo, financeiro, secretaria, telefonemas, terça-feira reunião com colegiado de pastores, discipulado com os pastores, para dar uma sequência nas decisões da reunião anterior, terça-feira tem uma reunião de oração com a equipe, a noção de organização é fundamental, se você deixar todos querem fazer a sua agenda, tenho atendimento no fim do dia da terça-feira. À noite faço visitas para as famílias da igreja, quarta-feira, preparo de sermão na parte da manhã, quarta à tarde gabinete pastoral, quarta à noite com a família, as viagens são programadas pelo menos uma vez por mês. Às vezes, preciso fazer uma gestão de horário por causa das viagens, almoços durante a semana são aproveitadas para reunião. Quinta-feira o dia inteiro para preparar o sermão, aproveito para almoçar com alguém, não escrevo o sermão inteiro, tem um roteiro a seguir na média de 4 a 5 páginas, todo esquema ligado com Power Point. Sexta-feira, dia de folga, às vezes um compromisso sexta à noite, normalmente tenho um dia de folga na sexta, tenho enxaqueca e procuro não tirar um dia de folga na segunda, sábado tento dar um dia de folga, se consigo cumprir com todas as atividades procuro dar o sábado livre. Domingo é o principal dia de atividades, cultos, no sábado estou em casa, sábado à tarde tiro livre, e domingo dia inteiro de trabalho ${ }^{281}$

Essa é uma marca dos pastores midiáticos, organização e muito trabalho.

Destacam-se alguns pontos:

1) Uma agenda pessoal rigorosa e muito bem organizada, pois não se faz um trabalho intenso de gravações, entrevistas, viagens, pregações, escrever livros e textos, sem ter uma agenda pessoal detalhada.

2) A noção do trabalho em equipe é fundamental, não se faz um trabalho abrangente sem ter um bom grupo de pessoas capacitadas para fazer a assessoria.

3) A agenda precisa de acompanhamento e filtro para ver a sua eficácia, não adianta planejar as tarefas e depois deixar as coisas sem serem

\footnotetext{
${ }^{280}$ Apêndice 1, Entrevistas, S4, 2016, p. 213.

${ }^{281}$ Apêndice 1, Entrevistas, S2, 2016, p. 201.
} 
executadas, é preciso voltar para os pontos marcados e ver o que foi realizado.

4) $\mathrm{Na}$ agenda pessoal, deve-se levar em conta o lado humano (família, lazer), atividades que, de certa forma, ajudam a relaxar e a manter a saúde emocional em dia, por exemplo, se presentear com um dia de folga, um jantar em família ou uma viagem de lazer.

Tenho vários sites conduzidos por 50 pessoas, atinjo 500 mil pessoas, tenho a coragem de dizer que entendo sobre todos os assuntos, e tenho coragem de dizer que errei e vou corrigir, faço questão de corrigir se não foi bom, se a pessoa reclama, peço desculpas, nas redes sociais não pode ser mentira, deve ser verdadeira e didática, verdadeira e ética, indico livros de Roger Olsen, Karen Armstrong, Baumam, Jean Paul Baudrillard, leio livros de ateus, evangélicos e católicos, na área de comunicação, tenho lido mais de 250 livros nessa linha de comunicação, quase todos já estão traduzidos. ${ }^{282}$

A assessoria é fundamental porque o alcance é imenso. Outra questão que surge é a importância da verdade, pois a mentira é algo que acaba com o trabalho de alguém que exerce o ministério midiático. Devido ao alcance das imagens e das mensagens, uma hora ou outra, serão confrontadas com a verdade. Não se deve vacilar, a verdade em primeiro lugar, a humildade para reconhecer quando errou, voltar atrás diante de um posicionamento que não foi correto ou até mesmo quando não está de acordo com os princípios bíblicos.

Aquele que exerce o ministério midiático não pode ter uma relação antagônica com a mídia.

A importância da mídia para vida pastoral, precisamos entender a realidade de hoje das redes sociais, web, rádio, tv aberta e fechada. Como formador de opinião, compreendo que o ser humano e um ser social e tenho interesse de mudar a sociedade falando da fé e de Deus, tudo isso tem impacto na vida pastoral, todos os veículos de comunicação estão no dia a dia de todo cidadão, a internet vai a todos os pontos do país. Por que não atingir aqueles lugares de sombra, por que não atingir com a rádio e a tevê, por que não atingir, com as rádios difusoras de $\mathrm{AM}$ e FM? Eu vejo como uma ferramenta fundamental para a ação pastoral, o negativo e o positivo de toda essa ação. Eu não sei quem está me assistindo, mas eu compreendo que vou impactar alguém de uma forma ou de outra, quem não se interessa pelo assunto pode desenvolver um senso crítico. Sem perder a realidade daquele que é um ser social. Eu continuo indo à padaria perto da minha comunidade, faço almoço e janta na padaria e lanches e tenho o convívio na vida comum, circulando junto à comunidade no meu espaço pastoral. Com a liberdade de caminhar com o povo tenho a ideia que esse ministério não é para estrelismo,

${ }^{282}$ Apêndice 1, Entrevistas, S4, 2016, p. 207. 
não sou artista, atuo como padre, não pretendo ser artista. Fama e lama caminham juntas. Será que estimulamos o fanatismo, se existe idolatria, será que nós somos responsáveis por isso. Precisamos equilibrar fé e razão. ${ }^{283}$

Aquele que exerce o ministério midiático deve estar consciente da realidade em que vive, o cidadão está conectado, os veículos de comunicação alcançam todos os pontos do país e fazem parte da vida das pessoas. Essa consciência e responsabilidade deve ser levada em conta. Pessoas serão impactadas pela mensagem, quem se interessar pelo assunto vai receber os benefícios. Analisando dessa forma, cabe ao ministro midiático fazer o melhor uso possível dessa ferramenta para comunicação.

Com o advento do computador, temos mais de 30 instrumentos para fazer evangelização. Ensinei isso para os alunos, mostrando as possibilidades da computação, como utilizar todos os veículos a sua disposição, mostrava os estúdios e gravações, o valor do som e da sonoridade, a importância dos templos para ensinar a falar no microfone e a repercutir, não só por show no palco, como do padre que usa o microfone e ensinar a usar técnicas de sonoridade e também visual, e também das capacidades de explorar as cores e os valores da televisão. Deve ficar claro que não pode ser uma televisão amadora, deve ser profissional e com muita ética, sem mentira, sem marketing e números falsos, isso acontece muito, reúne cinco mil, depois fala que tinha cinquenta mil, $150 \mathrm{mil}$, diz que tinha cinco milhões, tem vinte mil e fala que tem cem mil, a câmera só mostra um lado da igreja e passam isso para enganar o povo, isso tomou conta dos templos evangélicos e católicos. $\mathrm{O}$ fiel pensa que faz parte de uma igreja de 3 milhões quando na verdade só tem 200 mil, padres e pastores que vendem 30 mil e dizem que foi 3 milhões de livros, que vendeu 3 mil e dizem que foi $30 \mathrm{mil}$, isso é desonesto e uma igreja assim não tem credibilidade e não tem chance de prosperar espiritualmente. $^{284}$

Com o bom uso da mídia, de forma honesta e equilibrada, o alcance do evangelho será maior, mais pessoas serão abençoadas com a mensagem da salvação. Essas ações devem ser realizadas de forma autêntica, não se pode enganar as pessoas. Agir com sinceridade conta com a benção de Deus, quando se parte para o engano e a ilusão, deve-se estar certo que a benção de Deus não fará parte desse projeto. Segue algumas recomendações:

Não fique sozinho, ande em comunidade, não se distancie da realidade comunitária, essa realidade te ajuda no processo de socialização. Não deixe de olhar para o pobre, não deixe de investir e se relacionar com o pobre. Não deixe de dar uma boa risada de você mesmo, não pense de você além do que você é, não

\footnotetext{
283 Apêndice 1, Entrevistas, S3, 2016, p. 204.

${ }^{284}$ Apêndice 1, Entrevistas, S4, 2016, p. 220.
} 
pense de si mesmo, mais do que deve pensar. A fé crista é comunitária, falar do pobre é pensar que o poder não é neutro ele corrompe, ilude e mente. Essa coisa do poder que engana, essa coisa que você considerar o outro e o pobre é relativizar a si mesmo, como sobreviver diante das tentações. Eu fui falar no Comibam (2007) no México eu cheguei em uma cadeira de rodas, falei uma vez por dia e estava fragilizado, a questão do assédio, você não tem resistência. Uma questão do poder midiático é você ter resistência para não se deixar seduzir. ${ }^{285}$

A vida em comunidade de certa forma protege aquele que atua nos ambientes midiáticos. No entanto, a tendência quando o indivíduo se torna famoso é cair na solidão e não ter mais um grupo ou pessoas para prestar contas. Não se pode esquecer de onde veio e de suas dificuldades pessoais, deve-se ficar atento aos abusos do poder e seus desatinos, as fragilidades humanas mantém a pessoa atenta as suas limitações, esquecer-se disso é um risco.

O desafio do ministério pastoral é não perder a pessoalidade, não se pode ignorar as mídias o fator da digitalização da vida e ao mesmo tempo não pode fazer de conta que somos feitos de chip e de plástico. O mundo digitalizado não substitui o carinho, o afeto, o caminhar na praia, o contato com a esposa e os filhos. A vida digital não pode substituir os relacionamentos, é fácil refletir a sociedade impessoal, que tem cinco mil amigos nas redes sociais e não tem amigo de fato, se a igreja não é lugar para compartilhar sobre a minha dor, se não posso falar sobre o que está acontecendo comigo, a igreja é qualquer outra coisa menos igreja. ${ }^{286}$

Essa é uma tarefa do comunicador midiático, ao mesmo tempo em que ele tem um zelo por sua postura diante das câmeras e diante da vida e das pessoas, tem a preocupação de não perder a pessoalidade. Seus relacionamentos são sinceros e francos, porque sabe que é humano, e a mídia é apenas uma ferramenta de trabalho, não é a essência do ser humano nem o principal elemento para o ministério midiático, o qual se constrói a partir de um verdadeiro relacionamento com Deus, no cotidiano da oração e da espiritualidade encarnada.

Outro ponto a destacar é que as pessoas que atuam no ministério midiático não desejaram inicialmente estar nessa área. Há também a importância de Deus usar uma outra pessoa para motivar e capacitar o indivíduo para essa tarefa. As oportunidades que surgiram na caminhada também se fizeram importante.

Descobriram que eu tinha talento, nunca pensei, até os 27 anos, que iria fazer mídia, eu queria ser educador. Descobriram que eu cantava bem, que minhas músicas chegavam aos jovens. Comecei a ser chamado para pregar, formei jovens

\footnotetext{
${ }^{285}$ Apêndice 1, Entrevistas, S1, 2016, p. 202.

286 Apêndice 1, Entrevistas, S2, 2016, p. 205.
} 
para falar, me chamaram para falar nos estádios, para multidões, eu sou muito aceito, já cantei para 150 mil pessoas, muita gente chegou para aprender sobre como cantar e fazer show como motivar a multidão, e isso me levou para a multidão. Sempre fiz mídia católica, não me encantei com as grandes redes de televisão. Fiz uma opção de ser midiático religioso, quis trabalhar mais com o evangelho e editoras que publicassem temas religiosos, antes não havia editora que tinha interesse por assuntos religiosos. Achei que deveria desenvolver a nossa mídia, para não ficar à mercê das grandes gravadoras, eu fiz essa opção e nunca mudei, achei que fui formado pela igreja, e não era justo passar meu talento para outros grupos. Os motivadores foram Dom Elder, Dom Paulo, irmã Dulce, Dom Luciano, grandes bispos conhecidos na igreja. Cantei para quatro papas, fui a vários países para mostrar como o canto pode ajudar a orar e fazer catequese. ${ }^{287}$

Uma pessoa que tem a percepção para descobrir uma habilidade e se dispõe a desenvolvê-la para que as oportunidades apareçam, é padrão comum entre aqueles que exercem o ministério midiático. A recomendação é que sempre se procura de novos talentos nessa área e o processo deve continuar. Quem desejar exercer esse ministério precisa ter em mente a disposição de ajudar aos novos talentos, acreditar nas pessoas, dar oportunidade para elas, empenhar-se para ajudar os novos para que eles cresçam no ministério e possam ajudar muitas pessoas.

A partir das entrevistas e no decorrer da tese foi abordado a questão do poder midiático, cabe então abordar as questões relacionadas ao uso equilibrado e adequado do poder numa perspectiva midiática.

\begin{abstract}
O poder religioso é como uma espada de cinco pontas; se você não fizer um bom uso, vai machucar alguém. Todas as vezes que você tem uma câmera um microfone nas mãos, ou for imprimir um livro, e você não souber o que você está dizendo, pode criar um problema gravíssimo para a pessoa, às vezes não tem cura, às vezes pode se ensinar o medo, orgulho, visões erradas da bíblia. Com o poder na mão, pode se brincar de evangelizar, isso afeta e deturpa o legado do evangelho. É muito grande o número de pastores despreparados e padres ingênuos e depois dizem coisas que as pessoas saem dos templos com medo de Deus, pode ser um instrumento errado nas mãos erradas. Na maioria dos lugares, pregador errado, do jeito errado com o conteúdo errado. ${ }^{288}$
\end{abstract}

Percebe-se a seriedade do bom uso das ferramentas do ministério midiático, o rádio, a televisão, as redes sociais, a mídia impressa. Essas alternativas de comunicação devem ser usadas de forma adequada e pautadas na Bíblia, que é a base de fé para o discurso cristão.

Assim, os homens e as mulheres apresentados nas conferências como

\footnotetext{
${ }^{287}$ Apêndice 1, Entrevistas, 2016, p. 224.

${ }^{288}$ Apêndice 1, Entrevistas, S4, 2016, p. 224.
} 
aqueles aos quais vale a pena ouvir são pessoas carismáticas, servos altamente dotados; no entanto, esses são singularmente dotados em seus talentos naturais. Seus dons e personalidade não podem ser dobrados, postos numa caixa, embrulhados para presente, e enviados para casa. ${ }^{289}$

O ministério midiático precisa ser genuíno e ser construído a partir do serviço e da comunhão com Deus. No lugar-comum da existência humana, o cotidiano passa a ser "educativo" (aprender com as atividades do dia-a-dia). O indivíduo constrói sua identidade pastoral a partir de uma legitimidade recebida da parte de Deus, evidenciada pelos dons pessoais e ministeriais, e pelo reconhecimento do corpo.

Para ficar parecido verdadeiramente com o Mestre é necessário assumir a centralidade do Mandamento do amor, que Ele quis chamar seu e novo: "Amem-se uns aos outros, como eu os amei" (Jo 15,12). Este amor, com a medida de Jesus, com total dom de si, além de ser o diferencial de cada cristão, não pode deixar de ser a característica de sua Igreja, comunidade discípula de Cristo, cujo testemunho de caridade fraterna será o primeiro e principal anúncio, "todos reconhecerão que sois meus discípulos" (Jo 13,35). No seguimento de Jesus Cristo, aprendemos e praticamos as bem-aventuranças do Reino, o estilo de vida do próprio Jesus: seu amor e obediência filial ao Pai, sua compaixão entranhável frente à dor humana, sua proximidade aos pobres e aos pequenos, sua fidelidade à missão encomendada, seu amor serviçal até a doação de sua vida. Hoje, contemplamos a Jesus Cristo tal como os Evangelhos nos transmitiram para conhecer o que Ele fez e para discernir o que nós devemos fazer nas atuais circunstâncias. ${ }^{290}$

Isto é fundamental para orientar a ação da igreja, para dar uma referência, à itinerância, à caminhada do povo de Deus na história. "Postos os olhos em Jesus", quer dizer, no Bom Pastor, seu povo caminha e abre novas pistas em meio à realidade diária, referindo-se àqueles acontecimentos que experimentam a sua conjuntura; discernindo entre os mesmos a presença do Reino. Esses sinais do Reino, que se dão no tempo, devem ser apoiados, ratificados, através da ação pastoral. $^{291}$

A autoridade deve ser derivada da Palavra, não do cargo. Se um ministro não é fiel à Palavra e ao evangelho que ela proclama, ele é um usurpador. Não existe algo tal como "o ungido do Senhor" para pregadores que se colocam acima da Palavra de Deus, de cuja proteção foram encarregados. Qualquer reivindicação

\footnotetext{
${ }^{289}$ HORTON, Michael. Religião do Poder. São Paulo: Editora Cultura Cristã, 1998. p. 26.

${ }^{290}$ CELAM. Documento de Aparecida. Brasília: CNBB, 2007.

${ }^{291}$ ANA, Júlio Santa de. Pelas trilhas a caminho do Reino. S. P: Imprensa Metodista, 1998. p. 57.
} 
da autoridade divina através de comandos, expectações, "revelações" ou orientações, que não estejam firmadas nas páginas das Santas Escrituras, são marcas de tirania espiritual e de farisaísmo. ${ }^{292}$

O ministério cristão deve ser desenvolvido a partir de iniciativas do próprio Deus. Não adianta projetar um ministério pessoal baseado em alternativas humanas, como a exploração do místico e do sensacionalismo da religião ou desenvolver um estilo de vida alienado ao contexto em que se está inserido.

Há mais algumas considerações sobre esse poder pastoral. Pode-se observar uma mudança em seu objetivo. Já não se trata mais de uma questão de dirigir o povo para sua salvação no outro mundo, mas, antes, assegurá-la neste mundo. "Alguns dizem que vivemos numa realidade que terminou com as utopias, não existe mais lugar para o sonho e a esperança do porvir." 293

Herrmann comenta a frase de Lord Acton: "O poder tende a corromper, e o poder absoluto corrompe absolutamente" ${ }^{294}$, tornou-se um jargão após um século da nietzschiana "vontade de potência", no despertar da "morte de Deus". Nietzsche, filósofo alemão, predisse esta "era" e argumentou que, de agora em diante, poder, e não persuasão; ideologia, e não doutrina religiosa, preencheriam o vácuo deixado pelo esvaziamento de significado do cristianismo. ${ }^{295}$

Assim, a figura ministerial deve ter estas finalidades: gerar e incentivar novos sonhos, exercer um poder benevolente que incentive os outros a encontrarem seu espaço na sociedade, e a servirem da melhor maneira possível. Qualquer comunicador pastoral midiático que deixe de proteger seu povo com os cuidados e ensinos bíblicos, que não consiga distinguir um lobo na pele de um carneiro, subestima imensamente as responsabilidades de sua posição. As destrutivas falsas doutrinas e os erros graves de conduta dispersam o rebanho ou levam-no para uma armadilha ou a um precipício para sua destruição. ${ }^{296}$

Esse modelo traz consigo implicações distintas e variadas. A figura da igreja, da comunidade religiosa, com o advento de uma série de novas instituições

\footnotetext{
${ }^{292}$ HORTON, Michael. Religião do Poder. Trad. Wadislau Martins Gomes. São Paulo: Editora Cultura Cristã, 1998. p. 21.

${ }^{293}$ ROCHA, Zeferino. Esperança não é esperar, é caminhar. Revista Latino-americana de Psicopatologia Fundamental, v. 10, a. 2, 2007, p. 255-273.

${ }^{294}$ HERRMANN, Fabio. Análise didática: uma história feita de críticas. Jornal de Psicanálise, V.41, n.74, 2008, p. 71-111.

${ }^{295}$ HORTON, Michael. Religião do Poder. Trad. Wadislau Martins Gomes. São Paulo: Editora Cultura Cristã, 1998. p. 11.

${ }^{296}$ SHEDD, Russel P. Nos Passos de Jesus. São Paulo: Vida Nova, 1993. p. 87.
} 
sociais, não pode, através de sua figura pastoral, deixar fragmentar o seu nível de influência, mas deve provocar reações das mais diversas na sociedade.

Também se constata que a figura do ministro cristão, bem trabalhada e articulada, pode fazer diferença quando entende sua função numa perspectiva abrangente e social, tornando-se participante das diferentes classes, com uma proposta teológica contextualizada e midiatica conservando os valores das escrituras.

E isto implica que o poder do tipo pastoral que durante séculos - por mais de um milênio - foi associado a instituições religiosas, ampliou-se substancialmente por todo o corpo social; encontrou apoio numa multiplicidade de instituições. E, em vez de um poder pastoral e de um poder político, mais ou menos ligados um ao outro, mais ou menos rivais, havia uma "tática" individualizante que caracterizava uma série de poderes: da família, da medicina, da psiquiatria, da educação e dos empregadores. ${ }^{297}$

É preciso considerar algumas questões. A figura daquele que exerce o ministério midiático é forte. Ele exerce um poder abrangente porque conta com as estruturas religiosas em que está inserido. Cabe àqueles que exercem tal tarefa estarem fundamentados no "modelo bíblico de poder" (conduzir outros a salvação), servir à comunidade e estimular os sonhos e esperança do povo.

O desafio contemporâneo para a figura pastoral midiática é não se deixar levar e ceder aos encantos da modernidade, que na verdade não propõem muita coisa nova, mas estimula a repetição dos modelos tiranos que foram desenvolvidos no decorrer da história. A religião é um excelente palco para que indivíduos com más intenções e com sede de poder se estabeleçam sobre muitos, em nome de Deus, mas agindo para si.

Os que exercem as funções pastorais midiáticas devem tomar o cuidado e evitar o abuso do poder, não devem ser "dominadores dos que vos foram confiados". Muitos cristãos elevam os pastores a um alto pedestal. Alguns chegam até a adorar o homem que Deus tem usado para transformar vidas.

A adulação indevida encoraja o líder a manipular as pessoas, abusando de sua autoridade. Tais pastores são como os "falsos apóstolos" que perturbavam a igreja de Corinto (2 Co 11.13). Jesus advertiu seus discípulos quanto à tentação

\footnotetext{
${ }^{297}$ RABINOW, Paul; DREYFUS, Hubert. Michel Foucault. Uma trajetória filosófica para além do estruturalismo e da hermenêutica. Rio de Janeiro: Forense Universitária, 1995. p. 238.
} 
universal de "reinar" (Lc 22.25). Era um mau exemplo a famosa maneira pela qual os governantes romanos intimidavam e forçavam os subordinados a submeter-se a exigências opressivas. ${ }^{298}$

Há a necessidade de referenciais como o de João Wesley (século XVIII), a quem Deus escolheu para proclamar a mensagem da Reforma na Inglaterra. Ele percebeu que o evangelho era o poder de Deus para libertar o povo inglês, dentre outros pecados, da opressão da escravidão. No poder do evangelho do reino de Deus, ele enfrentou principados e potestades da economia, da política e da religião. E os enfrentou com a vontade divina que não deseja que nenhum dos seus pereça, mas que todos sejam salvos e libertos do grilhão da morte. Sua obra teve grande repercussão junto ao povo oprimido e empobrecido. ${ }^{299}$

Um modelo pastoral a ser seguido deve interagir com a sociedade, seguindo a ordenança divina e fazendo diferença onde for possível, apresentando um evangelho que seja orientador, libertador, e capaz de gerar esperança.

${ }^{298}$ SHEDD, Russel P. Nos Passos de Jesus. São Paulo: Vida Nova, 1993. p. 93.

${ }^{299}$ PAULY, Evaldo Luís, SCHÜNEMANN, Rolf. Org. Oneide Bobsin. Desafios Urbanos à Igreja. Et al. Arzemiro Hoffman. São Leopoldo, RS: Sinodal, 1995, p. 37. 


\section{Conclusão}

O tema a respeito do poder eclesial e sua relação com o ministério midiatico é fascinante. Nesta tese foram abordados conceitos e princípios que precisam ser divulgados e estudados a respeito desse assunto. Por meio do ensino pretende-se não perder a verdadeira essência do "poder" que se consolida com o "serviço", resultando assim nas abordagens da pesquisa.

Percebe-se já nas ações de Jesus essa preocupação. Ele pretendia consolidar o serviço como uma forma de identificação cristã. Para responder às questões relacionadas ao ministério midiático foi desenvolvida uma pesquisa através de entrevistas com quatro líderes midiáticos do Brasil com um alcance de milhares de pessoas. Através de estudos e das entrevistas, constatou-se a necessidade de oferecer material de apoio e conceitual tanto para aqueles que exercem essa tarefa quanto para aqueles que postulam a esse ministério.

No desenvolvimento deste trabalho foram estudados vários princípios que devem ser praticados por todos os seguidores de Jesus. Vários livros e movimentos cristãos foram levados em conta durante a pesquisa. Porém com o passar do tempo, os princípios e os conceitos foram se diluindo e se transformando em ilusões e mitos, pois cabe aquele que exercer o ministério midiático ser um guardião da verdade. Assim, os princípios precisam ser praticados para que não caiam no esquecimento e os valores devem ser reproduzidos por todos que neles acreditam. É preciso entender e divulgar que a influência do mais forte deve se transformar em serviço benéfico, de tal maneira que solucione e supra as necessidades do mais fraco.No desenvolver da pesquisa foram analisados vários aspectos relacionados ao assunto: $\mathrm{Na}$ origem dos termos entende-se que "o poder na sua essência é a capacidade de tomar decisões", porém, para os cristãos, deve resultar em serviço, tal qual o exemplo de Cristo. Jesus decidiu servir, Seu serviço era resultado de Seu interesse de ajudar aos necessitados. A força de Jesus era transmitida para o mais fraco. Quando Jesus falava, Seus pronunciamentos eram a favor daquele que não tinha voz e quando Se dispôs a morrer, foi por aqueles que precisavam resolver o problema do pecado.Assim como o poder é exercido através de sua influência, o poder midiático acontece a partir de um poderoso sistema, montado por diferentes 
correntes ideológicas que pretendem atingir o cidadão moderno. Desse modo, deve-se buscar contra essa força uma forma de proteção, a qual pode ser encontrada nas Escrituras Sagradas, que dizem que o poder pertence a Deus, e esse é um bom poder pois está baseado no amor.

O poder, numa análise mais ampla e geral, é a capacidade de agir em busca de seus interesses. A questão que deve ser salientada é que os interesses devem ser puros e não ter objetivos escusos. Weber define o poder como a possibilidade de fazer triunfar numa relação social a sua própria vontade, conseguir passar para uma pessoa, um sistema, uma sociedade, uma religião, pontos de seu próprio interesse, assim se consolida o poder.

O poder está presente desde o início, foi a partir do desejo de dominar que o ser humano foi se organizando em sociedade. Esse interesse pelo domínio sobre outros foi se consolidando de tal forma que o ser humano foi aperfeiçoando o uso do poder. Na essência, Deus concedeu ao ser humano a capacidade de escolher entre um ou outro caminho, ou seja, entre o bem e o mal, entre a submissão ou a insubmissão, e, dessa forma, o poder acontece.

Exercer poder de forma legítima é uma arte a ser conquistada pelos governantes. Na sua essência, esse poder deve ser exercido para o bem comum.

Um dos atributos do poder é a justiça, pois num ambiente de injustiça o poder se corrompe e perde a sua legitimidade. Para que a justiça aconteça precisa haver igualdade e os motivos devem ser justos. Cada indivíduo debaixo dessa ação do poder deve ter a liberdade de escolha e também deve ser responsável por seus atos e suas respectivas consequências. A Bíblia chega a ponto de exclamar: "Bem-aventurado o justo" (Salmo 1.1). A justiça é uma das formas de encontrar a felicidade.

Esse poder que a Bíblia apresenta através das ações de Deus e de seus servos e profetas, também a partir de Jesus e o Seu ministério, devem servir de referência para o bom uso dessa capacidade de influenciar outras pessoas. A essência do poder é amar e glorificar a Deus acima de todas as coisas, esse é um dos principais ensinamentos bíblicos.

Para que o exercício do poder seja genuíno, precisa ser exercido em um ambiente adequado.

O poder atrai e seduz, a força do poder está em apresentar possibilidades diferentes tanto para o bem quanto para o mal. Aqueles que se deixam seduzir 
sofrerão as devidas consequências de suas escolhas, engana-se aquele que acha que vai ser seduzido pelo poder sem sofrer as consequências.

O poder na mídia e a mídia e o poder, uma força imensurável de alcance, pois os diversos interesses que estão por trás das ações midiáticas, os grandes conglomerados midiáticos, que usam seu poder para vender, para influenciar e até mesmo para traçar o rumo da história.

Com os desenvolvimento dos veículos de comunicação, novas formas têm surgido, e uma nova conceituação do poder. A influência se torna maior, o alcance é sem fronteiras, o cidadão recebe o impacto da comunicação no seu próprio espaço geográfico e de tempo, assim se consolida o poder ultrapassando as distâncias.

Os computadores criaram novas possibilidades de transmissão, armazenamento e acesso à informação. Esse desenvolvimento está integrando a indústria da mídia aos diferentes interesses de uma sociedade. No entanto, pode-se afirmar que não existe comunicação neutra, sempre alguma ideologia está sendo defendida ou apresentada e os interesses não podem ser contrariados. O poder midiático vai se consolidando apesar de parecer invisível.

Tudo isso resulta em um sistema global de informações e influência. As indústrias da mídia são parte de conglomerados de informações que fazem acontecer um processo de transnacionalização.

Com o progresso nos sistemas de transmissão por cabo e por satélite, os argumentos tradicionais de controle vieram por terra. As grandes redes precisam vender seus produtos, o comércio prevaleceu, as organizações se profissionalizaram de forma comercial, com isso eles vão aumentando seu papel de dominação na nova economia global da informação e comunicação.

O consumismo exagerado criado pela mídia ${ }^{300}$ em geral pretende alcançar principalmente jovens e adolescentes para que se transformem em consumidores, apresentando modelos de roupas, estereótipos de modelos ideais a serem seguidos. Assim, essas pessoas da sociedade promovem o crescimento da indústria cosmética e farmacêutica, com seus produtos para inibir o apetite, e a indústria de roupas, com seus modelos novos que são lançados a cada dia

A teoria do agendamento afirma que as notícias que pautam o dia a dia e as

\footnotetext{
${ }^{300}$ FERREIRA, A. J.; STOBAUS, C. D.; GOUlART, D; MOSQUERA, J. J. M. Educação e Envelhecimento. Rio Grande do Sul: Edipucrs, 2012.
} 
conversas são definidas pelo poder da mídia de selecionar o mais importante no seu ponto de vista. Às vezes, o poder de convencimento da mídia parece manipulação, pois a mídia deve expor as notícias que julga importante e o público tradicionalmente deve analisar o seu conteúdo a partir do seu sistema de valores.

O fato é que o "poder" está passando por uma transformação histórica, a forma convencional do exercício do poder está enfrentando novos e surpreendentes modelos.

O poder está se transferindo daqueles que têm a força bruta para aqueles que têm o conhecimento e a tecnologia. Enquanto está sofrendo uma mutação, estados, empresas, partidos políticos, movimentos sociais e instituições ou lideranças lutam por ele.

O poder está se tornando mais frágil e vulnerável. Vive-se em tempos em que o poder se tornou mais concentrado e que aqueles que o detêm são mais fortes. Muitos pensam que o poder é igual o dinheiro que se tem na conta, quem tem mais dinheiro, tem mais poder, pois a partir desse ponto de vista o ciclo de concentração de poder e as riquezas se tornaram a mola mestra de funcionamento da história humana. No entanto, o poder se tornou mais disponível no mundo atual, mais pessoas têm mais poder.

O discurso religioso pós-moderno tem características próprias, pois além de buscar soluções imediatas para os problemas da vida, as quais geralmente estão nas pessoas e não no divino, permitem que haja uma busca em diversas religiões devido às incertezas. Os indivíduos passam a dar valor para o prazer, até mesmo o prazer religioso; o O futuro deixa de ser levado em questão, sendo que a realidade é viver o presente, sem levar em conta o passado e o que faz o sujeito feliz é o desenvolvimento de suas capacidades.

O poder religioso tem uma dimensão política. Com isso, pretende-se dizer que o poder religioso está relacionado com o poder institucional. Os líderes da sociedade precisam da religião para santificar os valores sociais e apoiar o controle social, por isso tendem a se proteger de ameaças da religião e as instituições religiosas. Os "poderosos" se entendem e fazem arranjos, geralmente, sem que o povo saiba o que está acontecendo.

As igrejas da pós-modernidade são ávidas na busca pelo sujeito religioso plural, fragmentado, desejoso por uma experiência e que vivem migrando de um local para outro. Nesse meio surge a cultura midiática que serve como base para 
apresentar novas estratégias e táticas para o recrutamento de novos adeptos.

Os cristãos tem como causa, buscar uma sociedade mais justa e igualitária, onde o cidadão tenha voz, onde os sistemas não sejam opressores ou totalitários, de forma que cada membro da sociedade possa se fazer representar ou representar o outro, tendo como base os valores e princípios apresentados pela palavra de Deus.

Deve-se buscar um poder santo, uma inspiração divina, um sistema que se assemelhe ao reino de Deus, onde as pessoas vivam em paz e contribuam para o bem geral de todos, um poder que se manifeste através do serviço e atenda às necessidades das pessoas.

Para isso, o ambiente da religião deve se manter puro, sem se contaminar pelos sistemas manipuladores das instituições midiáticas e os grandes oligopólios do poder de comunicação. A agenda da sociedade deve ser pautada pela justiça e a solidariedade entre os povos.

Parafraseando Kant, o poder é chamado ao serviço, mas inclinado à dominação. Esse é o seu paradoxo e sua trama. A raiz disso é que a potência busca a onipotência. Esse é o dinamismo auto expansivo do poder, exposto de modo muito realista por Hobbes no Leviatã: "O poder quer sempre poder e mais poder”.

As ações de poder devem resultar no serviço a favor das pessoas. Não se pode exercer o poder para manipular ou coagir indivíduos. O poder usado para explorar denigre o ser humano, a exploração do mais fraco traz à tona a má índole e expõe a opressão e a tirania do mais forte.

Os líderes religiosos atuais devem seguir Jesus. O ponto de partida são os ensinos de Jesus. Vários líderes têm sido afetados pelo secularismo, o qual afasta Deus das ações humanas. Jesus é Deus e deixou uma série de orientações para serem seguidas no cotidiano.

Jesus é o paradigma para a reflexão bíblica a respeito do poder. Com práticas contextuais e objetivas, Ele conseguiu agir dentro da cultura e do contexto social e político de sua época. Sua convivência com as pessoas e o Seu posicionamento político fizeram com que Ele reagisse e ao mesmo tempo se apresentasse como uma ameaça aos poderosos de seu tempo.

Jesus atuava a favor do povo, Suas propostas eram em busca de igualdade e liberdade para todos os que $\mathrm{O}$ seguissem. Apesar de as estruturas governamentais da época privilegiarem aos ricos e descendentes das famílias tradicionais de Israel, 
para Jesus essa não era (e não é) a forma de agir. Ele propõe que o rico atenda ao pobre, que o senhor assuma a posição de servo e que o pobre, o órfão, a viúva e o estrangeiro sejam atendidos em suas necessidades.

Em Jesus, pois, a função do pastor não é só religiosa: tem a ver com o propósito último de Deus que, nas palavras do autor da epístola aos Efésios, é "reunir sob uma só cabeça" (anakefalaiosis), Cristo, tanto os seres celestiais como os terrestres $($ Ef.1,10). É uma função que tem dimensão cósmica, mas também histórica.

Se o ministério cristão é para ser modelado pela missão de Cristo, certamente implicará em fazer o que Ele fez, assim deve-se participar do modo de vida das pessoas. Em se tratando de evangelização, isso significa entrar no mundo dos seus pensamentos, no mundo da sua tragédia e solidão a fim de compartilhar Cristo.

Além de Jesus, a Bíblia apresenta o Apóstolo Paulo como aquele que, de certa forma, dá continuidade aos ensinamentos do Mestre e aplica os princípios no desenvolvimento do seu ministério e no treinamento dos líderes das respectivas igrejas que foram estabelecidas por ele e por seu grupo de líderes.

Nas suas ações relacionadas ao serviço cristão, Paulo reconhece a participação de seus colaboradores. Na primeira carta aos Tessalonicenses, Paulo escreve: "Decidimos enviar-vos a Timóteo, irmão nosso e colaborador de Deus na proclamação do Evangelho de Cristo. Confiamos-lhe a missão de fortalecer-vos e de alentá-los na fé" (1 Ts 3,2). Paulo não diz: "nosso" colaborador, mas "aquele que trabalha para Deus". Em 1 Co 3,9, Paulo inclui: “Trabalhamos unidos na obra de Deus".

O líder cristão deve, portanto, exercer o poder a favor dos outros, não deve visar os seus interesses nem oprimir o mais fraco. Assim, o ministério deve ser pautado no serviço. Cabe àquele que se candidata ou que exerce o ministério, seguir o exemplo de Jesus, esse é o ponto de partida para que o ministério seja consolidado.

O ministério cristão não é uma invenção humana; antes, é uma instituição do próprio Deus, e o Senhor tenciona que a igreja cuide dos pobres. Diversas vezes Jesus faz alusão a este dever aos seus discípulos.

Se o ministério cristão é para ser modelado pela missão de Cristo, certamente implicará em fazer o que Ele fez. Em se tratando de evangelização, 
isso significa entrar no mundo dos seus pensamentos, no mundo da sua tragédia e solidão a fim de compartilhar Cristo.

Um ministério pastoral midiático que consiga fazer essa leitura e ser contextualizado ao ponto de propor um culto e uma participação comunitária simultânea, será significativo e se transformara numa ferramenta para o estabelecimento do reino de Deus. O ministério não pode se perder, exercendo uma função apenas cultualista, ritualista e conformista, mas precisa participar ativamente do modo de vida das pessoas, ter uma ação comunitária e apresentar propostas para a sociedade, que sejam permeadas pelos princípios do reino de Deus.

Aquele que exerce o ministério midiático deve estar ciente de que a mídia precisa ser pautada com os temas do evangelho.

O trabalho é intenso e a dedicação deve ser séria, exercer o ministério midiático não é uma tarefa "aventuresca" de pessoas que querem se promover através do rádio, televisão e das redes sociais. Aqueles que exercem essa tarefa devem estar conscientes dessa oportunidade não deve ser usada para vantagens pessoais ou para promoção individual. A tarefa é extenuante e precisa muita disciplina e organização pessoal para poder exercer o serviço com excelência.

Com o bom uso da mídia, de forma honesta e equilibrada, o alcance do evangelho será maior, mais pessoas serão abençoadas com a mensagem da salvação.

O ministério cristão não é uma invenção humana; antes, é uma instituição do próprio Deus, e o Senhor tenciona que a igreja cuide dos pobres. Diversas vezes Jesus faz alusão a este dever aos seus discípulos.

Um ministério pastoral midiático que consiga fazer essa leitura e ser contextualizado ao ponto de propor um culto e uma participação comunitária simultânea, será significativo e se tornará em uma ferramenta para o estabelecimento do reino de Deus.

O ministério não pode se perder, exercendo uma função apenas cultualista, ritualista e conformista, mas precisa participar ativamente do modo de vida das pessoas, ter uma ação comunitária e apresentar propostas para a sociedade, que sejam permeadas pelos princípios do reino de Deus.

Aquele que exerce o ministério midiático deve estar ciente de que a mídia precisa ser pautada com os temas do evangelho. 
“Ora, os dons são diversos, mas o Espírito é o mesmo. E também há diversidade nos serviços, mas o Senhor é o mesmo. E há diversidade nas realizações, mas o mesmo Deus é quem opera tudo em todos. A manifestação do Espírito é concedida a cada um visando a um fim proveitoso." (1 Co 12,4-6)

Soli Deo Gloria!

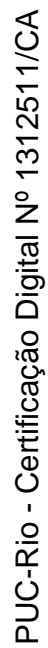




\section{Referências bibliográficas}

ACORDI, A. A influência da televisão na vida das pessoas. Criciúma: SATC - Educação e Tecnologia, 2012.

AGOSTINHO, S. Trindade. São Paulo: Paulus, 1994. VIII 10, 14.

ALBERTO, A. A presença da Igreja na cidade. Rio de Janeiro: Vozes, 1994.

ALLEN, C. J. Comentário bíblico Broadman. v. 12. Rio de Janeiro: JUERP, 1985.

ALMEIDA, Fernando José de. O educador: magnanimidades e ambiguidades. São Paulo em Perspectiva, v. 15, n.2, 2001, p. 92-95.

ALVES, R. Colarinho de Padre (Resenha). In: Religião e Sociedade, Rio de Janeiro, n. 6, p. 238, nov. 1980.

. Dogmatismo e Tolerância. São Paulo: Paulinas, 1982.

ANA, J. S. de. Pelas trilhas a caminho do Reino. São Paulo: Imprensa Metodista, 1998.

ANDERSON, P. As origens da pós-modernidade. Rio de Janeiro: Jorge Zahar, 1999.

ANDRE, L. Judaísmo, cristianismo e helenismo, São Paulo: Fapesp, 2007.

APPLE, M. W. Poder, significado e identidade - ensaios de estudos educacionais críticos. São Paulo: Porto Editora, 2003.

ARAUJO, M. P. N. 1968, quarenta anos depois. São Paulo: 7 Letras, 2009

ASSMANN, H. A igreja eletrônica e seu impacto na América Latina. Petrópolis: Vozes, 1986.

. Um rumor de anjos: A sociedade moderna e a redescoberta do sobrenatural. Petrópolis: Vozes, 1973.

Vozes, 1983.

Perspectivas sociológicas - uma visão humanística. Petrópolis:

ASSMANN, H.; LUCKMANN, Thomas. A construção social da realidade. Petrópolis: Vozes, 1999.

BAGDIKIAN, B. H. O monopólio da mídia. São Paulo: Scntta, 1993. 
BARBOSA, Ricardo. A igreja no mercado e o profissionalismo religioso. Contexto Pastoral, a. 7, n. 35, jan/fev, 1997. p. 6-7.

BARCLAY, W. The letters of James and Peter. Philadelphia (EUA): Westminster Press, 1976.

BARROS FILHO, C. Ética na comunicação: da informação ao receptor. São Paulo: Moderna, 1995.

BARTH, G. A primeira epístola de Pedro. 2. ed. São Leopoldo: Sinodal, 1979.

BARTH, K. Introducción a la teología evangélica. Salamanca (Espanha): Ediciones Sígueme, 2006.

BAUDRILLARD, J. A sociedade de consumo. Lisboa (Portugal): Edições 70, 2007.

BERGER, P. L. O dossel sagrado: Elementos para uma teoria sociológica da religião. São Paulo: Paulinas, 1985.

BERKHOF, L. Teologia sistemática. Campinas-SP: Luz para o caminho, 1998.

BERTRAND, R. Bertrand Russell in 90 minutes. Rio de Janeiro: Jorge Zahar, 2003.

BíBLIA. Português. Bíblia de Jerusalém. São Paulo: Paulus, 1985.

BIGNOTTO, N. Maquiavel. Rio de Janeiro: Jorge Zahar Editor Ltda, 2003.

BLANK, J. El evangelio según san Juan. Barcelona (Espanha): Editorial Herder, 1984.

BOFF, C. El Evangelio del poder-servicio. Bogotá (Colômbia): CLAR/Confederación Latinoamericana de Religiosos, 1988.

A igreja e o exercício do poder. Teologia do Poder. Maria Helena Arrochellas (org). Rio de Janeiro: ISER, 1992, p.42-52.

BOFF, L. Paixão de Cristo paixão do mundo. Petrópolis: Vozes, 1978.

. Igreja: Carisma e poder. Rio de Janeiro: Vozes, 1982. . Jesus Cristo libertador. 10 ed. Petrópolis: Vozes, 1985.

BOOR, W. de. Carta aos Colossenses. Comentário Esperança. Curitiba: Evangélica Esperança, 2002. 
- Evangelho de João. Comentário Esperança. Curitiba: Evangélica Esperança, 2002.

- Primeira Carta aos Tessalonicenses. Comentário Esperança.

Curitiba: Evangélica Esperança, 2007.

BOUDON, R. A ideologia. São Paulo: Ática, 1989.

BRATCHER, R. G. A translator's guide to the letters from James, Peter, and Jude. New York (USA): United Bible Societies, 1984.

BROWN, C.; COENEN, L. Dicionário internacional de teologia do Novo Testamento. 2. ed. São Paulo: Vida Nova, 2000.

BROWN, Raymond E. Comentario bíblico San Jerónimo. SS Union Theological Seminary, Nueva York. Tomo III. Madrid: Ediciones Cristiandad, 1972.

BROWN, R.; FITZMYER, J. A.; MURPHY, R. E.; CARM, O. Comentário Bíblico San Jerónimo. v. 3. Madrid: Ediciones Cristiandad, 1972.

BUCCI, E. Brasil em tempo de TV. São Paulo: Boitempo, 1996.

CALIMAN, C.; PINHEIRO, J. E. (Orgs.). O evangelho nas culturas. América Latina em missão. $5^{\circ}$ Congresso missionário latino-americano - COMLA 5. Petrópolis: Vozes, 1996.

CALVINO, J. As institutas da religião cristã: Edição especial com notas para estudo e pesquisa. São Paulo: Cultura Cristã, 2008. 4 vols.

CAMPOS, L. S. Destino pessoal e organização religiosa - um estudo de carreiras pastorais no interior de uma organização religiosa. São Bernardo, 1987. Dissertação (Mestrado). Instituto Metodista de Ensino Superior.

Teatro, templo e mercado: organização e marketing de um empreendimento neopentecostal. Petrópolis: Vozes, 1997.

A crise na formação do pastor protestante em um contexto de pós-modernidade. Contexto Pastoral, a. 7, n. 39, set., 1997. p. 23-28.

As mudanças no campo religioso brasileiro e seus reflexos na profissionalização do pastor protestante. Teoria e Pesquisa, Universidade Federal de São Carlos, jan./jul., 2002. p. 34-39

CAPOSSA, R. F. J. A mulher na comunidade do discípulo amado e sua dinâmica evangelizadora, a partir de João 4,1-43, tendo em conta os aspectos sociais, políticos, econômicos e religiosos. São Leopoldo (RS), março de 2006, 162 f. Dissertação (Mestrado em Teologia 
e Bíblia) - Instituto Ecumênico de Pós Graduação em Teologia, Escola Superior de Teologia.

CARVALHO, A.; MARTINS, S.; VELOZO, V. O poder da mídia. São Paulo: Lê, 1997.

CASTELLS, M. A sociedade em rede. São Paulo: Paz e Terra, 1999.

CATÃO, Francisco. A Nova Evangelização. Revista de Cultura Teológica. ISSN (impresso) 0104-0529 (eletrônico) 2317-4307 74 (2011): 11-29. Disponível em: http://revistas.pucsp.br/index.php/ culturateo/article/view/15340. Acesso em: maio 2016.

CAVALCANTI, R. A Igreja, o país e o mundo; desafios a uma fé engajada Viçosa (MG): Ultimato. Revista Reflexão, 2000.

CELAM. Puebla: A evangelização no presente e no futuro da América Latina. Petrópolis: Vozes, 1979.

. Documento de Aparecida. Brasília: CNBB, 2007.

CHAMPLIN, R. N. Enciclopédia de bíblia, teologia e filosofia. 4. ed. São Paulo: Candeia, 1997.

. O novo testamento interpretado. São Paulo: Candeia, 1995.

O novo testamento interpretado versículo por versículo. v. 2. Guaratinguetá: A Voz Bíblica, 1998.

C.M.I. Uma igreja para o mundo - um estudo das estruturas missionárias da congregação. Conselho Mundial de Igrejas. Edições Oikomene, 1969.

COHEN, B.; WESTFALL, R. S. (orgs.). "Isaac Newton-Textos, antecedentes, comentários/escolhidos.". Rio de Janeiro: ContrapontoEDUERJ, 2002.

COLSON, C. W. Religião de poder. São Paulo: Cultura Cristã, 1998,

COMSTOCK, L. K. Anton Koberger e sua marca. Louis K. Comstock, 1930. Disponível em: http://tipografos.net/historia/koberger.html. Acesso em: 07/04/2016.

CONCÍLIO VATICANO II. Compêndio do Vaticano II: Constituições, decretos e declarações. 23ạ. Petrópolis: Vozes, 1994.

CRUZ, R. TV digital no Brasil - tecnologia versus política. São Paulo: SENAC, 2008.

CORTEN, A. Os pobres e o Espírito Santo: O pentecostalismo no Brasil. Petrópolis: Vozes, 1996. 
COSTA, J. F. Campeonato de irrelevâncias. Folha de São Paulo, Caderno Mais, Junho 2001.

COSTA, O. E. El protestantismo en America Latina hoy. Ensayos del camino. Pasadena, California: Publicaciones INDEF, 1975.

Evangelizacíon contextual, fundamentos teológicos e pastorais. San José: Sebila, 1986.

CURTIS, A. K.; LANG, J. S.; PETERSEN, R. Os 100 acontecimentos mais importantes da história do cristianismo. São Paulo: Vida, 2003.

DANIEL-ROPS, H. A vida diária nos tempos de Jesus. São Paulo: Vida Nova Editora, 2003.

DEBERGE, Pierre. Ética do poder, abordagem bíblica e teológica. São Paulo: Paulinas, 2002. (Coleção Ética e Sociedade.)

DEBORD, G. A sociedade do espetáculo. São Paulo: Editora Verso, 1990. p. 240.

DE FLEUR, M. L. Teorias de comunicação de massa. Rio de Janeiro: Zahar, 1971.

DENHAM, J. R. Concordância fiel do Novo Testamento. São José dos Campos: Fiel, 1994.

DESCARTES, R. Discurso do Método: meditações, objeções e respostas. As paixões da Alma e Cartas. São Paulo: Abril Cultural, 2000.

DIJK, T. A. V. Discurso e poder. São Paulo: Contexto, 2008.

DONNER, D. História de Israel e dos povos vizinhos. São Leopoldo: Sinodal, 1997.

DREYFUS, H. L.; RABINOW, P. "Sobre a genealogia da Ética: uma visão do trabalho em andamento". Michel Foucault. O Dossier: últimas entrevistas. Rio de Janeiro: Taurus, 1984.

DUFOUR, X. L. Vocabulário de Teologia Bíblica. Barcelona: Herder, 2001.

DUPUIS, J. Rumo a uma teologia cristã do pluralismo religioso. São Paulo: Paulinas, 1999.

EAGLETON, T. Ideologia. São Paulo: Boi Tempo Editorial,1997.

ELLIOT, P. Sociología de las profesiones. Madrid (Espanha): Tecnos, 1975. 
. Dinheiro, sexo e poder. São Paulo: Mundo Cristão, 1988.

EYLER, F. M. S. História Antiga, Grécia e Roma: a formação do Ocidente. Petrópolis, R.J.: Vozes, PUC Rio, 2014.

FERREIRA, A. J.; STOBAUS, C. D.; GOULART, D; MOSQUERA, J. J. M. Educação e Envelhecimento. RS, Porto Alegre, Edipucrs, 2012.

FONSECA, M. A. Michel Focault e a constituição do sujeito. São Paulo: EDUC, 2011.

FOUCAULT, Michel. Microfísica do poder. Rio de Janeiro: GRAAL, 1999.

. O Sujeito e o poder. Rio de Janeiro: Graal. 1999.

FREIDSON, E. Renascimento do profissionalismo. São Paulo: Edusp, 1998.

FREITAS, B. P. A beleza hiper real. São Paulo: Clube dos Autores, 2008.

FOSTER, R. Celebração da disciplina - O caminho do crescimento espiritual. São Paulo: Vida, 1984.

FURIATI, C. Fidel Castro, uma biografia consentida. São Paulo: Revan, 2002.

FRITJOF, C. O ponto de mutação. São Paulo: Cultrix, 2000.

GALENO, Eduardo. As veias abertas da América Latina. Rio de Janeiro: Editora Paz e Terra, 1980. p. 38.

GERHARD, B. A primeira epístola de Pedro. São Leopoldo: Sinodal, 1979.

GEZA, V. Jesus e o mundo do judaísmo. São Paulo: Loyola, 1996.

GIMENEZ, J.; PERDIGÃO, Z. O quarto poder. São Paulo: Asa, 2002.

GNILKA, J. Jesus de Nazaré: mensagem e história. Petrópolis: Vozes, 2000.

GREJO, C. B.; BUNGE, C. O.; INGENIEROS, J. Entre o científico e o político, pensamento racial e identidade nacional na argentina (18801920). São Paulo: Unesp, 2009.

GRIMAL, P. Mitologia gGrega. Porto Alegre: LSPM, 2013. 
GUNDRY, R. H. Panorama do Novo Testamento. 2. ed. São Paulo: Vida Nova, 1998.

GUTIERREZ, B.; CAMPOS, L. S. No poder do Espírito, pentecostais e protestantes históricos na América Latina. São Paulo: Pendão Real, 1996.

GYARMATI, G. et al. Las profesiones: dilemas del conocimiento y del poder. Santiago (Chile): Ediciones Universidad Católica de Chile, 1984.

HABERMAS, Jungen Consciência moral e agir comunicativo. Rio de Janeiro: Tempo Brasileiro, 1989.

. Teoria do agir comunicativo: sobre a crítica da razão funcionalista. WMF Martins Fontes, 2012.

. Direito e democracia: entre facticidade e validade. Rio de Janeiro: Tempo Brasileiro, 1997.

Discurso filosófico da modernidade. Lisboa: Publicações D. Quixote, 1990.

. Técnica e ciência como ideologia. São Paulo: Abril Cultural, 1975. (Coleção Os Pensadores)

. LUHLWR H GHPRFUDFLD - Entre faticidade e validade. Rio de Janeiro: Tempo, 1997. p. 38.

HALE, B. D. Introdução ao estudo do Novo Testamento. 2. ed. Rio de Janeiro: JUERP, 1986.

HALL, S. A identidade cultural na pós-modernidade. Rio de Janeiro: DP \& $A, 2001$.

HANNDT, A. A condição humana. Rio de Janeiro: Forense Universitária, 1989.

HANNUCH, M. E. M. Conflitos no exercício do ministério pastoral. Cadernos de Pós-Graduação. Questões pastorais contemporâneas. Ciências da Religião, São Bernardo do Campo, UMESP, n. 7, out. 1992.

HARPER, A. F. Beacon Bible Commentary. Kansas City (USA): Beacon Hill Press, 1967.

HARRISON, E. F. Comentário bíblico Moody. São Paulo: EBR, 1983.

HENDRIKSEN, W. Comentário al Nuevo Testamento: El Evangelio según San Marcos. Michigan (EUA): Libros Desafío, 1998.

HERNANDES, N. A mídia e seus truques. São Paulo: Contexto, 2010. 
HERRMANN, Fabio. Análise didática: uma história feita de críticas. Jornal de Psicanálise, v. 41, n.74, 2008, p. 71-111.

HOLLANDA, H. B. de (Org.). Pós-Modernismo e Política. Rio de Janeiro: Rocco, 1992.

HOLMER, U. Primeira carta de Pedro. Comentário Esperança. Curitiba: Esperança, 2008.

HORTON, M. Religião do poder. Cambuci-SP: Cultura Cristã, 1998.

HORSTER, D. et alii. Habermas zur Einführung. Hamburg: Soak, 1988.

HÖRSTER, G. Introdução e Síntese do Novo Testamento. Curitiba: Esperança, 1993.

HUYSSEN, A. Mapeando o pós-moderno. In: HOLLANDA, H. B. de (Org.). Pós-Modernismo e Política. Rio de Janeiro: Rocco, 1992.

INSTITUTO CATEQUÉTICO SUPERIOR DE NIJENGEN. BUENO, Nuevo Catecismo para adultos. Versión íntegra del Catecismo Holandés. Espanha: Editorial Herder, 1969.

JAMESON, F. A cultura do dinheiro: ensaios sobre a globalização. Petrópolis: Vozes, 2001

JAMIESON, R.; FAUSSET, R.A.; BROWN, D. Comentario exegético y explicativo de la Biblia. 8. ed. El Passo (USA): Casa Bautista de Publicaciones, 1983.

JOÃO PAULO II. Pastores Dabo Vobis: sobre a formação dos sacerdotes. Exortação Apostólica. 4. ed. Pós Sinodal, 1992.

JOHN, H. Seja um líder de verdade. Belo Horizonte: Betânia, 1986.

JOHN, S. O cristão em uma sociedade não cristã. Niterói: Vinde Comunicações, 1989.

JONES, P. A ameaça pagã. Mukilteo (WA): Wine Press Publishing, 1998.

JOSEF, B. El evangelio según San Juan. Barcelona: Editorial Herder, 1984.

JOSEFO, F. História dos hebreus. Rio de Janeiro: CPAD, 2004.

JOSUTTIS, M. Prática do evangelho entre política e religião. São Leopoldo: Sinodal, 1979.

JULIO, A. S. Pelas trilhas a caminho do Reino. São Paulo: Imprensa Metodista, 1998. 
JURGEN, H. Dialética e Hermenêutica - para a crítica da hermenêutica de Gadamer. Porto Alegre: L\&PM, 1988.

. Teoria de la acción comunicativa, Racionalidad de la acción y racionalización social. Madri: Taurus, 1987.

KIRCHHEIM, H. Pastorado em discussão. São Leopoldo: Sinodal, 1979.

KNIGHT, A. E., ANGLIN, W. História do cristianismo. Rio de Janeiro: Casa Publicadora das Assembleias de Deus, 1983.

LASSWELL, H.; KAPLAN, A. D. Poder e sociedade. Brasília: Universidade de Brasília, 1999.

LATOURELLE, R.; FISICHELLA, R. Dicionário de Teologia Fundamental. Rio de Janeiro: Vozes, 1994.

LAUBACH, F. Carta aos hebreus. Comentário Esperança. Curitiba: Evangélica Esperança, 2000.

LEIGHTON, F. Jesus: O maior revolucionário. Niterói: Vinde Comunicações, 1984.

LEONARD, E. G. O protestantismo brasileiro. Estudo de eclesiologia e história social. 2. ed. Rio de Janeiro / São Paulo: JUERP/ASTE, 1981.

LEVY, B. H. La barbarie à visage humain. Paris: Grasset, 1977. p.86

LIPPMANN, W. Public Opinion. Nova York: MacMillan, 1922.

LUCIO, M. N. Sociologia de poder. México: Universidade Autônoma de México Cidade Universitária, 1976.

LUTERO, M. Coleção Lutero Para Hoje. Concórdioa: Sinodal, 2000

LYOTARD, J. F. O pós-moderno. Rio de Janeiro: José Olympio, 1986.

MACHIAVELLI, N. B. D. O Príncipe. Rio de Janeiro: Civilização Brasileira, 1976.

MAISELS, C. K.. Early Civilizations of the Old World, The formative histories of Egypt, the levant, Mesopotamia, India and China. EUA: Routledge, 2001.

MARIANO, R. Neopentecostais: Sociologia do novo pentecostalismo no Brasil. São Paulo: Loyola, 1999.

MARTELLI, S. A religião na sociedade pós-moderna. São Paulo: Paulinas, 1995. 
MATTHES, J. Introduccion a la sociologia de la religión. Madrid: Alianza Editorial, 1971.

MEDELLIN, II Conferência Geral do Episcopado Latino Americano, 1968.

MEDINA, J. Ortega y Gasset no exílio português. Centro de História: Universidade de Lisboa, 2004.

MENDONCA, A. G. A versão protestante nacional de ministério. In. Cristianismo y Sociedad. São Bernardo do Campo: UMESP, 1981.

. Protestantes, pentecostais e ecumênicos. O campo religioso e seus personagens. São Bernardo do Campo: UMESP, 1997.

. O celeste porvir: A inserção do protestantismo no Brasil, São Paulo: Paulinas, 1984

A identidade reformada e as transformações sociais. Revista Teológica, Campinas, Seminário Presbiteriano do Sul, v. 59, n. 48, jan./abr., 1998.

MENDONCA, A. G.; VELASQUES FILHO, P. Introdução ao Protestantismo no Brasil, São Paulo: Loyola, 1990.

MENDOZA, Á. C. El colapso del sujeto posmoderno: Nihilismo y Mistica, La ruta fenomenológica de la subjetividad expuesta. México: Universidad Iberoamericana, 2008.

MIRANDA, M. F. Igreja e Estado democrático na sociedade secularizado. In: Revista Eclesiástica Brasileira. v. 71, fasc. 283, julho de 2011.

MOISES, N. O fim do poder. São Paulo: Texto Editores, 2013.

MORA-ANDA, E. História dos ideais. Brasília: Thesaurus, 2006.

MORAIS, R. C. Neoliberalismo, de onde vem, para onde vai. São Paulo: SENAC, 2001.

MUELLER, E. R. I Pedro: Introdução e Comentário. São Paulo: Vida Nova, 1988.

NASCIMENTO, S. Os novos escribas. Porto Alegre: Arquipélago Editorial, 2010.

NOELLE-NEUMAN, E. La espiral del silencio. Opinión Publica: nuestra peil social. Barcelona: Paidós, 1995.

O’DEA, T. F. Sociologia da religião. São Paulo: Pioneira, 1969. 
O'REILLY, A. J. Os Mártires do Coliseu. 3. ed. Rio de Janeiro: Casa Publicadora das Assembleias de Deus, 2005.

ORLANDO, C. El Protestantismo en America Latina hoy (1972-1974). Ensayos del Camino. 1975. San José: INDEF, 1975.

PAGOLA, J. A. Jesus: aproximação histórica. Petrópolis: Vozes, 2011.

PAULY, E. L.; SCHÜNEMANN, R. Desafios Urbanos à Igreja. São Leopoldo: Sinodal, 1995.

PAUPÉRIO, A. M. Teoria democrática da soberania. Rio de Janeiro: Florense Universitária, 1997.

PEDROSO, D.; COUTINHO, L.; SANTI, V. J. Comunicação midiática, matizes, representações e reconfigurações. R.S, Porto Alegre: Edipucrs, 2011.

PIERRE, B. A economia das trocas simbólicas. São Paulo: Perspectiva. 1987.

PIERUCCI, A. F. Reencantamento e dessecularização: O propósito do auto-engano em sociologia da religião. Novos Estudos Cebrap, n. 49, 1997.

PINTO, C. C. A cidade é a minha paróquia. São Paulo: Editeo, 1996.

PLONER, K. S., et al., (org). Ética e paradigmas na psicologia social. Rio de Janeiro: Centro Edelstein de Pesquisas Sociais, 2008. 313 p.

POHL, A. Comentário esperança evangelho de Marcos. Curitiba: Evangélica Esperança, 1998.

- Evangelho de Marcos. Comentário Esperança. Curitiba: Evangélica Esperança, 1998.

RABINOW, P.; DREYFUS, H. Michel Foucault. Uma trajetória filosófica para além do estruturalismo e da hermenêutica. Rio de Janeiro: Forense Universitária, 1995.

RIBEIRO, A. P. G.; FERREIRA, L. M. A. Mídia e Memória: a produção de sentidos nos meios de comunicação. Rio de Janeiro: Mauad Editora, 2007.

RICARDO, B. Janelas para vida. Curitiba: Encontrão, 1999.

RICHE, P. Vida de São Bernardo. São Paulo: Edições Loyola, 1991.

RIENECKER, F. Evangelho de Lucas. Comentário Esperança. Curitiba: 
Evangélica Esperança, 2005.

- Evangelho de Mateus. Comentário Esperança. Curitiba: Evangélica Esperança, 1998.

RIENECKER, F.; ROGERS, C. Chave linguística do novo testamento Grego. São Paulo: Vida Nova, 1995.

ROBSON, C. No princípio era o Verbo. In: F. T. L., Curitiba (PR): Encontrão, 1986. p.179.

ROCHA,Zeferino. Esperança não é esperar, é caminhar. Revista Latino americana de Psicopatologia Fundamental, v. 10, a. 2, 2007, p. 255273.

RODRIGUES, R. G. O evangelho do Poder. In: Fraternidade Teológica Latino Americana, No princípio era o Verbo. Curitiba (PR): Encontrão Editora, 1994.

ROGERS, Juan D. Ideologia e Conhecimento da Realidade SócioEconômica-Política. Curitiba: Editora Encontro, 1986. p. 196.

SACKS, H. 'Some Technical Considerations of a Dirty Joke'. (1978) In: SCHENKEIN, J. (ed.). Studies in the Organization of Conversational Interaction. New York, NY: Academic Press. pp. 249-269.

SANTOS, Tarcyanie Cajueiro. A sociedade de consumo, os média e a comunicação nas obras iniciais de Jean Baudrillard. Revista Galáxia, São Paulo, jun 2011, n. 21, p. 125-136.

SAVAZONI, R.; COHN, S. Cultura digital.br. São Paulo: Azougue Editorial, 2009.

SAYÃO, L. A. Novo Testamento trilíngue: grego, português e inglês. São Paulo: Vida Nova, 1998.

SCHULLER, A. Dicionário Enciclopédico de Teologia. R,S, Porto Alegre: Concórdia, 2002.

SELWYN, E. G. The first epistle of st. Peter. London: Macmillan, 1958.

SHEDD, R. P. I Pedro, Abordagens Pastorais. São Paulo: Vida Nova, 1983.

Nos passos de Jesus. São Paulo: Vida Nova, 1993.

SILVA, M. P. Reforma do Estado e democracia, uma comparação entre o Brasil e a Rússia. Brasília: Vestnik, 2014.

SILVEIRA, J. R. A profissão de pastor presbiteriano na cidade de São 
Paulo. São Bernardo do Campo, 2005. Dissertação (Mestrado), UMESP.

SILVEIRA, R. A.; FOCAULT, M. Poder e análise das organizações. Rio de Janeiro: FGV, 2005.

SIQUEIRA, Ruy Dos Santos. Da ritualização da sociedade ao fetiche consumogônico. São Paulo: UMESP, 2006.

SODRÉ, N. W. História da imprensa no Brasil. São Paulo: Mauad, 1999.

SOUZA, W. E. Pastores em crise: O conflito da identidade social do pastor Presbiteriano. São Bernardo do Campo, 1998. Dissertação (Mestrado), UMESP.

STEURNAGEL, V. R. No princípio era o verbo. Evangelho, Cultura e Missão. Curitiba: Encontrão, 1994.

STIBBS, A. M., WALLS, A.F. Tyndale new testament comentaries. Grand Rapids: Eerdmans, 1959.

STOTT, John R. W. A mensagem de 2 Timóteo. 3. ed. São Paulo: ABU, 1989.

STRONG, J. Léxico Hebraico, Aramaico e Grego de Strong. Versão eletrônica. São Paulo: Sociedade Bíblica do Brasil, 2005.

SWINDOLL, C. Firme e seus valores. Belo Horizonte: Betânia, 1985.

TARDE, G. A opinião e as massas. São Paulo: Martins Fontes, 1992.

TEIXEIRA, F.; MENEZES, R. (Orgs). As religiões no Brasil: continuidades e rupturas. Petrópolis: Vozes, 2006.

TENNEY, M. C. O novo testamento: sua origem e análise. 3. ed. São Paulo: Vida Nova, 1995.

THEISSEN, G. O movimento de Jesus. São Paulo: Loyola, 2008.

THOMPSON, J. A mídia e a modernidade. Uma teoria social da mídia. Petrópolis: Vozes, 1998.

THOMPSON, T. H. O. Ideologia e cultura moderna. Teoria Social Crítica na era dos meios de comunicação de massa. Petrópolis: Vozes, 1995.

TOFFLER, A. As mudanças do poder. Rio de Janeiro: Record, 1990.

TOLSTÓI, L. 0 reino de Deus está em vós. 2 ed. Rio de Janeiro: Rosa Dos Tempos, 1994. 
TRIPP, D.; HODGE, R. I. V. Children and television: A semiotic approach. Stanford University Press, 1986.

TUANA, N. (ed.) Feminism and science. Bloomington: Indiana University Press, 1987.

TURNER, D. D. Introdução ao novo testamento. São Paulo: Imprensa Batista Regular, 1987.

VICENTE, M. M. História e comunicação na nova ordem internacional. São Paulo: Cultura Acadêmica, 2009.

V.V.A.A. O clero num mundo em crise. Atas da IX Conferência Internacional de Sociologia Religiosa, Montreal, 1967. Petrópolis: Vozes, 1969.

WACH, J. Sociologia da religião. São Paulo: Paulinas, 1985.

WEBER, M. Economia e sociedade. Fundamentos da sociologia compreensiva, v.1. Brasília: Editora da UNB, 1991.

. Ensayos sobre sociologia de la religión. Madrid: Taurus, 2001.

. Ciência e política, duas vocações. São Paulo: Pensamento Cultrix Ltda, 2005.

WIERSBE, W. W. Comentário bíblico expositivo. Santo André: Geográfica, 2006.

WILLAIME, J.P. O pastor protestante como tipo específico de clérigo. Estudos de Religião, São Bernardo do Campo, UMESP, n. 25, dez., 2003.

Prédica, culto protestante e mutações contemporâneas do religioso. Estudos de Religião, São Bernardo do Campo, UMESP, n. 23, dez., 2002.

- O Protestantismo como objeto sociológico. Estudos de Religião, São Bernardo do Campo, UMESP, n.18, jun., 2000.

WILLARD, D. O Espírito das disciplinas. Rio de Janeiro: Danprewan, 2003.

WILLIAMS, D. J. Novo comentário bíblico contemporâneo - Atos. São Paulo: Vida, 1998.

ZUP, R. Oficio y modelos pastorales: analisis y reflexiones sociológicas desde Nicarágua. Managua: Cieets-Vision Mundial//ndef, 1996. 


\title{
APÊNDICE A
}

\section{Transcrição Das Entrevistas}

\author{
ROTEIRO PARA ENTREVISTA
}

ENTREVISTA 01 - SE1

\section{PERFIL DO ENTREVISTADO}

Nome: SE1

Escolarização: Mestrado e Doutorado com ênfase em Missiologia nos EUA

Você possui ou participa:

Facebook: (X) Sim ( ) Não

Lista de discussão em comunidades virtuais: ( $x$ ) Sim ( ) Não

Participa de alguma comunidade virtual: ( x ) Sim ( ) Não

\section{1) Quem é você de acordo com suas atividades?}

Acredito por causa da vocação, tem a ver com o mistério do chamado de Deus, a experiência de que Deus estava me chamando, essa experiência, determinou minha vida, essa experiência de vocação, saber ser colocado no mundo a partir daquilo que Deus tem para mim. Eu acredito na minha vocação e quero ser uma pessoa sensível a realidade humana, principalmente a necessidade de escutar o gemido humano, quanto mais santo mais humano, o ser humano carece desse evangelho, esse encontro com o evangelho torna a pessoa mais humana. A vocação e o serviço ao outro.

\section{2) Fale sobre sua vocação}

A vocação me levou para o estudo da teologia, eu estudei teologia clássica eu me aprofundei fui fazer Mestrado e Doutorado com ênfase em Missiologia nos EUA, a vocação me levou para necessidade de abraçar uma vocação mais acadêmica, para ser qualificado para vivencia da vocação, essa teologia, e continuo estudando. 
Eu não conclui o curso de ciências sociais, voltando a minha vocação, tem a ver com o sentido da vida, com o pobre. Eu sempre procurei que aminha teologia você uma teologia encarnada, o meu envolvimento com a visão mundial, me levou para o serviço ao pobre, formação precisa ser acadêmica e também em precisa ser relacional, precisa ser mística, precisa ter abertura para a o mistério, para o outro para essa escuta, preciso escutar o acadêmico e o espiritual. A visão mundial foi fundamental para a minha vocação.

\section{3) Quais são as suas atividades midiáticas?}

O exercício da vocação te torna uma pessoa pública, minha função tem a ver com o microfone, com a comunicação, isso significa estar no circuito das palestras de eventos no Brasil e fora do Brasil. Eu sou um comunicador do evangelho, também na comunicação escrita, escrever eu faço parte de uma escola de uma teologia latino-americana, teologia que procura dialogar com o continente, na minha escrita procure expressar isso, por 20 anos escrevo uma coluna para Revista Ultimato $^{301}$, levei uma revista Ultimato para o Clodovis Boff, a terceira ação midiática, e a construção de relacionamentos Congresso Brasileiro de Evangelização $^{302}$, tem a ver com a construção de relacionamento, congresso brasileiro de evangelização, um trabalho de mentoria de jovens livres, grão de mostarda, também[em a ABU.

\footnotetext{
${ }^{301}$ A Editora Ultimato, com sede na cidade mineira de Viçosa, na Zona da Mata, é membro da AEVB (Associação Evangélica Brasileira) e da AsEC (Associação de Editores Cristãos). Fundada em 1968 com a publicação de Ultimato, um tabloide de oito páginas em papel jornal, hoje a revista Ultimato, começou a publicação de livros em 1993, tendo hoje mais de 150 títulos em catálogo. Ultimato acredita que toda Escritura, além de inspirada por Deus, é também útil. Isso faz diferença. Não mexemos no conteúdo bíblico, mas nos damos a liberdade de colocá-lo numa embalagem nova. Relacionamos Escritura com Escritura e Escritura com acontecimentos. Trabalhamos para criar uma mentalidade bíblica e ensinar a arte de encarar os acontecimentos sob uma perspectiva cristã. A missão da Editora Ultimato é contribuir para a transformação de vidas e edificação da Igreja, por meio da publicação de conteúdo cristão. Ao lado de muitos outros, participa da proclamação da boa nova que nunca fica velha, da esperança que nunca morre e de um Salvador que nunca muda. Relacionamos Escritura com Escritura e Escritura com acontecimentos. Pretendemos associar a teoria com a prática, a fé com as obras, o estudo com a simplicidade, a evangelização com a ação social, a oração com a ação, a conversão com a santidade de vida, o suor de hoje com a glória por vir.www.ultimato.com.br 12122015

${ }^{302}$ Com a presença de 855 pessoas (incluindo preletores e participantes), notadamente das regiões Sul (37,5\% dos participantes) e Nordeste $(25,4 \%)$, de várias denominações evangélicas, realizouse em Belo Horizonte, de 27 de outubro a $1^{\circ}$ de novembro de 2003, o Segundo Congresso Brasileiro de Evangelização (CBE2), sob o lema "proclamar o Reino de Deus, vivendo o evangelho de Cristo". Disponível em: http://www.ultimato.com.br/revista/artigos/286/cbe-2 Acesso em: 12/12/2015
} 


\section{4) Como é o seu cotidiano?}

A atividade pastoral e caótica, uma das prioridades, mistério pastoral, comunicação do evangelho, relacionamento com pessoas, gestão de igrejas, palestra e escrever, preparo de material, publicação de material, a aliança crista evangélica brasileira, tem a ver com a questão de comunicação.

\section{5) Como você foi inserido nesse ambiente midiático?}

Como você entrou nesse ambiente de comunicação? Alguém me colocou, a vocação me leva para busca de formação e a essa busca me leva a me posicionar no contexto da realidade em que eu vivo, a vocação me insere, uma das primeira inserções foi através da $\mathrm{ABU}^{303}$, isso aconteceu quando estava estudando teologia, grupo de universitários no contexto de ditadura militar foi uma escola de vida, a aliança bíblica me ajudou a ser inserido no contexto da universidade brasileira. A formação mais a capacitação vai resultar no ambiente midiático, pessoas me ajudaram a descobrir o continente. Abu me ajudou a descobrir o brasil, FTL $^{304}$ me

\footnotetext{
${ }^{303}$ A Aliança Bíblica Universitária do Brasil (ABUB) é uma organização missionária evangélica que existe para compartilhar o Evangelho de Jesus Cristo nas escolas e universidades brasileiras, através da iniciativa dos próprios estudantes. $\mathrm{O}$ treinamento e formação de estudantes e profissionais, visando o testemunho cristão e o serviço à Igreja e à sociedade, completam nossa missão. Nossa visão: Estudantes que formam comunidades de discípulos, transformados pelo Evangelho, e que impactem o mundo estudantil, a igreja e a sociedade para a glória de Cristo. Nossos objetivos: A evangelização dos secundaristas, universitários e profissionais, por intermédio da comunicação da mensagem do evangelho e da demonstração prática da vivência cristã, objetivando sua submissão ao senhorio de Jesus Cristo. O desenvolvimento dos secundaristas, universitários e profissionais rumo à maturidade do ser humano integral em Cristo Jesus, nos aspectos pessoal e comunitário, de forma a assumirem sua responsabilidade no âmbito da família, da igreja e da sociedade. A realização de missão e serviço pelos estudantes e profissionais, mediante a descoberta de seu lugar de chamado por Deus, na Igreja e no mundo. Assistência ao estudante e à comunidade, visando ao desenvolvimento do homem e da mulher, como manifestação do amor de Deus, em Cristo. Em 2012 encerramos o ano com 107 grupos filiados à ABUB (88 grupos de estudantes universitários, 14 de ensino médio e 5 de profissionais), em 91 diferentes cidades brasileiras. http://www.abub.org.br/quem-somos 12122015.

${ }^{304}$ Somos um movimiento evangélico que, desde a década de 70 , promove espaços de reflexão teológica contextualizada no colorido e machucado cenário da América Latina. Nossas reuniões de fraternidade e diálogo comunitário com a Palavra são marcadas pela diversidade do povo evangélico e pelo compromisso com o Reino de Deus e sua expressão na vida e missão da igreja latino-americana. Somos uma associação sem fins lucrativos, composto por mulheres e homens comprometidos com a vida evangélica e missão do povo de Deus na América Latina. A Missão FTL como parte da igreja, promove espaços fraterno de diálogo e reflexão bíblico-teológica da América Latina. Queremos uma igreja latino-americana que - transformada pela Palavra e pelo Espírito - fermente todas as áreas da vida de nossos povos como agente do Reino de Deus e sua justiça. http://ftl-al.org/quienes-somos/ 12122015
} 
ajudou a descobrir o continente latino e a Visão Mundial ${ }^{305}$, a descobrir o mundo.

\section{6) Na sua experiência, o que é fundamental para o ministério pastoral midiático?}

A questão fundamental e a questão do evangelho, a fé, a crença de que que o evangelho que faz diferença na vida das pessoas e fundamental para todos, esse encontro do evangelho que te ajuda a viver, e fundamento para entender o teu jeito de se posicionar na sociedade, a grande pergunta e desenvolver um ministério pastoral comunitário, esse evangelho tem uma dimensão, bíblica quando uma dimensão comunitária publica, ele gera uma vida que faca diferença, se expressa em comunidade mas tem uma dimensão, quais são as peças que a gente junta no ministério pastoral, uma boa formação, ele precisa espiritualidade e precisa de testemunho público e boa gestão, nossa igrejas se tornam grandes e nesse fato se tornam vítimas do mercado, precisa ser desenvolvida uma resistência ao mercado. Essa formação e uma espiritualidade solida e que vai consolidar seu testemunho.

\footnotetext{
3051950 - Criação da Visão Mundial Em 1947, o norte-americano Robert Pierce, pastor e correspondente de guerra, ao visitar um orfanato na ilha de Xiamen (Estreito de Formosa Taiwan), se sensibilizou com a situação de White Jade, uma criança órfã da guerra. A professora alemã Tena Hoelkedoer, incapaz de cuidar da menina sozinha, pediu ajuda a Pierce, pois o orfanato não tinha condições de prover alimento para mais órfãos. Bob Pierce, como era conhecido, deu à professora seus últimos cinco dólares e fez um trato com ela: todos os meses enviaria a mesma quantia para ajudá-la a cuidar de Jade. É nessa promessa que está a causa da Visão Mundial, fundada por Bob Pierce, três anos depois, em 22 de setembro de 1950. Após a Guerra da Coreia, Pierce teve a ideia de ajudar os milhares de órfãos através de doações mensais. Também na Coreia, em 1954, o primeiro escritório de campo da Visão Mundial foi fundado. Nas décadas seguintes, a Visão Mundial expandiu seu trabalho pela Ásia, América Latina, África e Leste Europeu. Nos anos 1970, ao perceber que o apadrinhamento tradicional não atacava as causas da pobreza, a Visão Mundial implantou o modelo de desenvolvimento comunitário e de assistência humanitária em situações de emergência, que vem sendo constantemente aprimorado até hoje. O compromisso da Visão Mundial é com a transformação da sociedade por meio de mudanças das estruturas sociais e sistemas injustos que oprimem as pessoas e reduzem as possibilidades de desenvolvimento das comunidades, especialmente crianças, adolescentes e jovens. Para que isso seja possível, promovemos a justiça para a infância, a ajuda humanitária e a reabilitação, de modo a garantir um desenvolvimento transformador e sustentável. Trabalhamos em parcerias com as comunidades, com foco no bem-estar de crianças, adolescentes e jovens dentro da perspectiva dos valores cristãos. A Visão Mundial está presente em mais de 90 países. Alguns deles, como Estados Unidos, Canadá, Austrália, Itália, França e Espanha, são países de fomento, ou seja, arrecadam fundos a serem destinados a países cujos IDH (Índices de Desenvolvimento Humano) são muito baixos e necessitam de ajuda internacional. Países como o Brasil, por exemplo, além de receber recursos do exterior, também promovem ações de captação interna, seja por meio do apadrinhamento de crianças, doações únicas ou de ações como "Doe para uma causa" e "Catálogo de Presentes". Globalmente, a Visão Mundial também atua em situações de crises e emergências, como catástrofes naturais (secas, enchentes, terremotos, tsunamis e outros), guerras e conflitos armados, mesmo em áreas onde não tenha programas de desenvolvimento. Disponível em: https://visaomundial.org.br. Acesso em: 12/12/2015.
} 
O testemunho do evangelho tem pouco de uma ética pública, tem muito mais do mesmo, ela precisa vencer o mercado, a gestão vai te ajudar a vencer o equilíbrio, o ministério pastoral hoje é complexo, não se pode ceder ao mercado e a cultura e não se pode perder a relevância, cada geração precisa enfrentar seus desafios.

\section{7) Quais as tecnologias que você usa para desenvolver suas atividades ministeriais?}

A escrita tem sido a principal ferramenta o microfone, as redes sociais uso pouco, tem uma coisa de geração eu sou da geração da palestra, da escrita, do microfone, e estou enfrentando o desafio de se converter. Eu uso Iphone, computador, Tablet, máquina fotográfica, filmadora.

Quais são as suas atuações nas redes sociais, tenho sido mais promovido do que me promover, a ultimato tem divulgado minhas entrevistas com os pais da missão integral, essas atividades de vídeo, estou tentando ampliar, na igreja usa mais e mais tecnologia.

\section{8) Quais vantagens e desvantagens da mídia e a pregação do evangelho?}

No ponto de vista teológico a gente vive em vantagens e desvantagens, cidadão do reino dos céus e do reino encarnado. Cada tempo e cada época precisa fazer essa leitura, período de anjos e demônios, nesse sentido não se demoniza o mundo de hoje e santifica o mundo de ontem. Tem desafios que precisam ser respondidos com as ferramentas de nossa época e não com o instrumental de ontem. Não adianta dizer que vivemos em uma sociedade liquida, precisamos aprender a se comunicar com essa sociedade. Precisamos aprender a nos comunicar no padrão do twitter. Qual seria o critério fundamental para isso, o que [e que impede de anunciar o evangelho na sua totalidade para o público que você quer conversar, você tem espaço para o anuncio do evangelho na sua totalidade, se a tua mídia não te permite falar do evangelho. O vídeo tem limitações para o anuncio do evangelho mais integral, precisa entrar numa análise mais profunda, sobre que tipo de mídia nós estamos falando, e como essa mídia nos ajuda na pregação do evangelho na dimensão profética, a mídia comercial, você converte o 
evangelho a mídia que você usa, nenhuma mídia e neutra nem ontem e nem hoje.

\section{9) No seu ponto de vista, o que é o poder religioso?}

Poder espiritual é o mais sensível dos poderes, porque ele lida com o transcendente, não existe atuação publica que não tenha uma dimensão do poder, qualquer atuação publica comunitária implica no poder, o exercício do ministério pastoral é um exercício de poder, essa é a realidade, não se pode viver a ilusão de que não queremos caminhar no uso do poder, falar é poder, caminhar é poder, o poder religioso evoca o transcendente e por outro lado envolve o emocional o aspecto vulnerável da vida da pessoa, você fazer uso dessa autoridade espiritual traz consequências diversas.

Quando um indivíduo afirma: Deus está mandando me dizer que, você deve me obedecer, esse é um poder enorme, entra no fundo da alma humana, assim se corre o risco da manipulação, a vontade humana, você pode não comprar com ouro e prata, mas compra com a linguagem do coração, precisamos falar com mais clareza de que a questão não é o uso do poder, mas o poder está a serviço de quem, da cruz ou da manipulação, o que consolida o poder religioso é o serviço, de alguma forma o poder da cruz é o poder do amor.

\section{0) No seu ponto de vista, como deve ser exercido o poder religioso?}

Deve ser exercido através do serviço, Jesus é o modelo para o exercício do poder, o modelo do poder serviço representado no lava-pés, tem dimensões comportamentais humanas, se Jesus é o modelo, o fator galileia ${ }^{306}$, por onde Jesus

\footnotetext{
${ }^{306}$ Deixamos com Josefo (Guerra Judaica 3,41-42) profundo conhecedor da Região por causa das suas campanhas militares a apresentação do lugar: Há duas Galileias, uma chama-se a alta e a outra a baixa, ambas são limitadas pela Fenícia e Síria. Do lado do ocidente estão as cidades de Tolemaida, todo o seu território e o Monte Carmelo, que outrora pertencia aos Galileus e agora é dos tirios, perto do qual está a cidade de Gamala, chamada a cidade dos cavaleiros, porque o rei Herodes para lá mandava os dispensados. Do lado do Sul tem, na fronteira, a Samaria e Citópolis, até o Rio Jordão. Do lado do oriente os seus limites são Hipom, Gadaris e Galaunita, que são também os do reino de Agripa. E do lado do Norte confinam com Tiro e seus territórios. O povo Galileu, embora estas duas províncias estejam rodeadas de tantas e diversas nações, todavia elas sempre lhe resistiram em todas as suas guerras, porque além de serem instruídos desde a infância na arte da guerra. As terras são férteis e tão bem plantadas com todas as espécies de arvores, que sua abundancia convida a cultiva-las mesmo aqueles que tem pouca inclinação para a lavoura e não há terras inutilizadas. Não somente há uma grande quantidade de aldeias e vilas, mas também grande número de cidades, tão populosas que a menor delas tem mais de quinze mil habitantes.
} 
andou, com quem Jesus andou, contato com as crianças, com o pobre, sua decisão de ir para Jerusalém para morrer, é o poder do serviço, fundamentalmente e o poder do amor, o poder religioso, deve ser exercido com amor que te leva para o serviço que é sacrificial, serviço ao pobre e a mulher sofrida, ao estrangeiro. A teologia sendo analisada do ponto de vista da vítima, não do conquistador. Uma das vertentes do movimento de Laussane é a vida simples, encarnação, viver de forma consistente servindo, não vive o poder do comercio nem do palácio, mas da simplicidade, do abraço e do serviço.

\section{1) Como o poder religioso se relaciona com a mídia?}

O poder religioso precisa subverter a mídia influenciando e dando pautas para uma agenda não contraditória. A mídia é como o quarto poder, a mídia não é neutra, ela precisa ser descortinada, precisa revelar a serviço de quem ela está. O evangelho diz para a mídia a serviço de quem ela está, porque a essência do Evangelho é verdade e justiça. A mídia precisa ser denunciada quando está a serviço da exploração e da riqueza, basicamente o poder religioso, precisa denunciar e precisa conseguir anunciar o evangelho para a necessidade de uma sociedade justa, onde a verdade seja importante, onde o pobre seja protegido, o evangelho precisa ajudar a mídia a ter esse olhar. A mentira prevalece na sociedade atual, a mentira e um componente político atual, o evangelho deve ajudar a mídia a vencer a mentira e proclamar a justiça e a verdade.

\section{2) Quais são as vantagens e as desvantagens entre a religião e a mídia?}

Em determinado sentido não temos a possibilidade de responder essa pergunta, precisamos deixar de usar certos segmentos da mídia. Existe uma vertente da história que diz: Não faço uso da mídia contemporânea. Uma corrente que não se deixa levar, uma tradição anabatista, onde você se impõe, através da negação do uso.

Outra corrente do mundo evangélico e até católico, precisa-se usar a mídia para o benefício do evangelho, a pergunta se a mídia te dar espaço para o 
evangelho de Jesus, se a mídia permite a denúncia, se não permite se te castra é um desserviço ao evangelho. Tem vantagens e desvantagens.

\section{3) Quais são as recomendações para que o indivíduo não se envolva em situações de abuso do poder?}

Não fique sozinho, ande em comunidade, não se distancie da realidade comunitária, essa realidade te ajuda no processo de socialização. Não deixe de olhar para o pobre, não deixe de investir e se relacionar com o pobre. Não deixe de dar uma boa risada de você mesmo, não pense de você além do que você é, não pense de si mesmo, mais do que deve pensar.

A fé crista é comunitária, falar do pobre é pensar que o poder não é neutro ele corrompe, ilude e mente. Essa coisa do poder que engana, essa coisa que você considerar o outro e o pobre é relativizar a si mesmo, como sobreviver diante das tentações. Eu fui falar no Comibam( 2007) no México eu cheguei em uma cadeira de rodas, falei uma vez por dia e estava fragilizado, a questão do assedio, você não tem resistência. Uma questão do poder midiático é você ter resistência para não se deixar seduzir. 
ENTREVISTA 02 - SE2

\section{BLOCO 01 - PERFIL DO ENTREVISTADO}

Nome: SE2

Escolarização: Engenheiro mecânico, teologia na graduação, mestrado e doutorado no Estados Unidos, em 1988 cheguei no Brasil sempre aperfeiçoando, e a igreja local sempre foi prioridade junto com o ensino teológico, a igreja sempre possibilitou essa parceria.

Você possui ou participa:

Facebook: (X) Sim （ ） Não

Lista de discussão em comunidades virtuais: ( x ) Sim （ ) Não

Participa de alguma comunidade virtual: ( x ) Sim （ ) Não

\section{1) Quem é você de acordo com suas atividades?}

Sou pastor da Igreja Batista Bacacheri ${ }^{307}$ há 27 anos, sou professor da faculdade Batista do Paraná, fui professor de curso de Bacharel em Teologia, sou professor do Instituto Haggai da matéria Criatividade no Evangelismo, tenho lecionado crescimento de igrejas em outras faculdades. A respeito da denominação batista, no Paraná, no Brasil ( já fui presidente no Paraná e no Brasil) e atualmente na Convenção Mundial sou representante da América Latina no Conselho da Convenção Batista Mundial. Uma convenção batista funciona

\footnotetext{
${ }^{307}$ Em setembro de 1944 um pré-seminarista de nome Tito Ribeiro, da Igreja Batista do Cajuru, pregou pela primeira no bairro do Bacacheri. Logo mais, em 1945, o trabalho foi reconhecido como congregação da Igreja Batista do Cajuru, tendo uma frequência média de 50 pessoas participantes da Escola Bíblica e também do culto vespertino. Numa segunda fase do trabalho, no dia 28 de junho de 1950, a Primeira Igreja Batista de Curitiba comprou o terreno na rua Gago Coutinho no qual foi construído o primeiro templo e inaugurado em 07/09/1951, pelo missionário Ben Oliver. Nesta mesma data foram eleitas as diretorias da Escola Bíblica e da União de Treinamento "João Emílio Henck". A partir daí a PIB Curitiba ficou responsável pela realização dos cultos. Foi criado também um ambulatório que prestava atendimento à comunidade dirigido pelo Dr. Natanael de Souza e França. Em 7 de setembro de 1959, às 13h, é organizada então a Igreja Batista do Bacacheri, com 30 membros fundadores. O primeiro pastor foi Benedito Serafim Rosa. Outros pastores que pastorearam a igreja foram: Pedro Serafim, Ephraim de Souza Rosa, Dirceu Amaral, André Scott, Décio Freitas, Roy Deller, Horst Treümann, Manoel Xavier dos Santos Filho, Jorge Ramos Pereira e atualmente o pastor L. Roberto Silvado, que serve em nossa igreja desde 1988 e hoje atua como coordenador geral do colegiado de pastores, que você pode conhecer mais. Nossa Missão Ser uma igreja acolhedora, discipuladora e multiplicadora, que na dependência de Deus promove a transformação integral de pessoas, sociedades e povos. Nossa Visão Na dependência de Deus, ser reconhecida como uma Igreja que promove a transformação integral do ser humano. http://www.ibb.org.br/ 28122015
} 
através da cooperação de igrejas que se organizam e formam as convenções e aliança batista mundial se organizam mundialmente para cumprir alguns propósitos, essa convenções cumpram seus propósitos e tem um acento na ONU e luta por direitos humanos, e centenas de convenções ao redor do mundo é uma das primeiras a chegar diante das catástrofes, são mais de 142 países .

\section{2) Por que você acredita na sua atuação?}

Deus abre portas e promove oportunidades e dá dons para promoção do seu reino, e estou atento as oportunidades que Deus dá, eu não acredito que eu devo fazer as coisas acontecerem ao meu favor, eu preciso ver o que Deus está fazendo e se unir ao que ele está fazendo.

\section{3) Fale sobre sua formação.}

Engenheiro mecânico, teologia na graduação, mestrado e doutorado no estados unidos, em 1988 cheguei no Brasil sempre aperfeiçoando, e a igreja local sempre foi prioridade junto com o ensino teológico, a igreja sempre possibilitou esse parceria.

\section{4) Quais são as suas atividades midiáticas?}

Programa de rádio, programa de televisão para internet, atividade devocionais na internet, vidanet, estão disponíveis na rede, tenho as redes sociais, Facebook, twitter, vídeos pequenos para os membros e se tornam públicos, vídeos rápidos para temas de época. Jornais e revistas publicadas semanalmente para igreja e jornal mensal, tudo disponível na internet, tem o site da igreja onde apresenta os programas das igreja.

\section{5) Como é o seu cotidiano?}

Um caos organizado, tenho uma agenda básica, que tento seguir, trabalho muito na igreja, dou expediente, preparo sermão, segunda feira, é um dia administrativo, financeiro, secretaria, telefonemas, terça feita reunião com 
colegiado de pastores, discipulado com os pastores, para dar uma sequência nas decisões da reunião anterior, terça feira tem uma reunião de oração com a equipe, a noção de organização é fundamental, se você deixar todos querem fazer a sua agenda, tenho atendimento no fim do dia da terça feira a noite faço visitas para as família da igreja, quarta-feira, preparo de sermão na parte da manhã, quarta a tarde gabinete pastoral, quarta à noite com a família, as viagens são programadas pelo menos uma vez por mês, as vezes preciso fazer uma gestão de horário por causa das viagens, almoços durante a semana são aproveitadas para reunião, quinta feira o dia inteiro para preparar o sermão, aproveito para almoçar com alguém, não escrevo o sermão inteiro, tem um roteiro a seguir na média de 4 a 5 páginas, todo esquema ligado com Power Point, sexta feira dia de folga, as vezes um compromisso sexta à noite, normalmente tenho um dia de folga na sexta, tenho enxaqueca e procuro não tirar um dia de folga na segunda, sábado tento dar um dia de folga, se consigo cumprir com todas as atividades procuro dar o Sábado livre, Domingo é o principal dia de atividades, cultos, no sábado estou em casa, sábado à tarde tiro livre, e domingo dia inteiro de trabalho

\section{6) Como você foi inserido nesse ambiente?}

Não tem escolha, a situação vai te levando a fazer e a desenvolver aspectos na comunicação, vai escrevendo textos, vai sendo puxado para o ambiente da comunicação, normalmente não existe uma intencionalidade, quando você percebe já estava fazendo.

\section{7) Pensando no ministério pastoral efetivo, quais são a suas considerações?}

O desafio do ministério pastoral é não perder a pessoalidade, não se pode ignorar as mídias o fator da digitalização da vida e ao mesmo tempo não pode fazer de conta que somos feitos de chip e de plástico, o mundo digitalizado não substitui o carinho o afeto, o caminhar na praia, o contato com a esposa e os filhos, a vida digital não pode substituir os relacionamentos, é fácil refletir a sociedade impessoal, que em cinco mil amigos nas redes sociais e não tem amigo de fato, se a igreja não é lugar para compartilhar sobre a minha dor, se não posso falar sobre o que está acontecendo comigo, na igreja, é qualquer outra coisa 
menos igreja,

\section{8) Quais são as tecnologias que você usa para desenvolver suas atividades?}

Computador, Redes Sociais, Tablet, Power Point, Vídeos, Telefone Celular. Eu resisto usar as mídias para autopromoção, 3 vezes por dia um post sobre o indivíduo, que a foto dele é maior do que a mensagem, a autopromoção, e teológico, se você tem efésios 4 como base de sua teologia, você vai entender que a o ministério e da igreja. Caso contrário vai divulgar a pessoa.

\section{9) Quais são as vantagens e as desvantagens?}

A desvantagens é a falta de pessoalidade e a vantagens é a possibilidade de alcançar pessoas em todos os lugares do mundo, entrar em lugares inimagináveis, que não tem a limitação do tempo e do espaço, o grande desafio é o como fazer o acompanhamento dos relacionamentos, as vezes se diz que a mídia é demoníaca, a mídia é amoral, não tem identidade, nós é que damos a característica moral e ética, como nós usamos é que vai definir a moral

\section{0) O que é o poder o religioso?}

Em termos espirituais é toda a manifestação do poder de Deus, do Espirito Santo do sobrenatural, o que todo ser humano anseia mesmo sem saber, o poder religioso é o grande anseio do ser humano. Sem o sobrenatural de Deus o ser humano cria manifestações para demonstrar o poder, é a manifestação negativa do poder religioso, um líder carismático pode usar a religião para se auto promover, o poder que nos levou as cruzadas e atualmente leva a exploração, falta o poder religioso verdadeiro que é a ação do Espirito Santo, o ser humano tenta produzir.

\section{1) Como deve ser exercido o poder religioso?}

Jesus é o modelo e Paulo vai dizer que precisamos dos frutos do espirito.

\section{2) Como o poder religiosos se relaciona com a mídia?}


O positivo não vende, o ser humano corre atrás da magia, o balcão de negócios com Deus, apesar do avanço da tecnologia digital, tem um limitador, a religião estão caminhando para uma resistência absurda, a televisão tem ajudado no Brasil a diminuir a resistência a religião, apesar do principal canal de televisão no Brasil não ter programa religiosos.

\section{3) Quais são as vantagens entre a mídia a religião?}

Uma ajuda a outra, se você tem manipulação, onde alguns programas religiosos e manipulação pura, a política se mistura com a religião as vezes de forma doentia, onde as trocas de favor são absurdas.

14) Quais são as recomendações para não se envolver em abuso do poder midiático?

Ética, não cair na armadilha da vaidade, e do poder, o custo da mídia, leva a pessoa a vender a alma para poder pagar o custo da vinculação midiática. Outra recomendação é você ter um grupo de pessoas a quem prestar contas, uma garantia que não vai tomar decisões erradas. 


\section{ENTREVISTA 03 - SE3}

\section{BLOCO 01 - PERFIL DO ENTREVISTADO}

Nome: SE3

Escolarização: Colegial básico e técnico em eletrônica, filosofia instituto Boa Ventura e teologia na PUC São Paulo, fiz direito e também um aperfeiçoamento em teologia para poder trabalhar na área pastoral. Fiz vários cursos paralelos, para exercer funções na mídia, fez um curso de direito

Você possui ou participa:

Facebook: ( x ) Sim ( ) Não

Lista de discussão em comunidades virtuais: ( $\mathrm{x}$ ) Sim ( ) Não

Participa de alguma comunidade virtual: ( x ) Sim ( ) Não

\section{1) Quem é você para as suas atividades?}

Trabalho na RC na Rede Católica da Igreja, Curitiba, Paraná, trabalho na rede século XXI, trabalho na rádio capital, com Eli Correia, também na Web TV, textos sagrados com reflexão todos os dias, cedo a voz para propagandas para atividades sempre ligadas a fé e a religião.

\section{2) Por que você acredita na sua atuação?}

Eu acredito na atuação de Deus, Ele age como quem tem autoridade, eu me permito para ser usado por Deus para comunicar as boas novas, eu não teria a mesma desenvoltura para comunicar em outras atividades, ser cristão é minha vida, pertencer a igreja católica é minha vida, viver essa fé é minha vida, nasci nessa religião. $\mathrm{O}$ creio no que eu faço, porque creio na vida eterna e em Cristo.

\section{3) Fale sobre sua qualificação.}

Colegial básico e técnico em eletrônica, filosofia instituto Boa Ventura e teologia na PUC São Paulo, fiz direito e também um aperfeiçoamento em teologia para poder trabalhar na área pastoral. Fiz vários cursos paralelos, para exercer funções na mídia, fiz um curso de direito. Na faculdade de direito eu já fazia 
alguns programas de casa mesmo, até que veio a oportunidade na rede Brasil e depois a Liliane ventura foi a pessoa me treinou e me mostrou o que eu deveria fazer, e pontuando algumas questões tanto negativas quanto positivas, foi o trabalho na benção na web, depois a rádio com Eli Correia Rádio Capital, depois surgiu a rede século vinte e um com padre Eduardo, com aconselhamento ao vivo e depois eu fiz esse programa durante três anos, a noite, devocionais e também um programa de auditório, louvemos ao senhor, e depois com o padre Manzonti, me dispus para ajudar na expansão da rede, RCI e a TV evangelizar e Radio Evangelizar, Século XXI não chegou a ser uma fusão com a RCI a união de retransmissoras da TV Evangelizar em todas as capitais brasileiras, 61 cidades novas até o final de 2016.

\section{4) Quais são as suas atividades midiáticas?}

Gravações para programas de bênçãos e orações, desenvolvo um trabalho de apresentações e na TV Século XXI um novo programa, na rede católica da igreja, tem o programa fé na vida e com a palavra todas as manhãs e também o noite de louvor, a maioria dos programas são ao vivo.

\section{5) Como é o seu cotidiano?}

Eu sou pároco, tenho uma paróquia e uma capela, tenho um instituto e sou o vice-presidente, Amigos da Fé, organização com cunho pedagógico, cuida de crianças que são filhos de pais portadores de vírus HIV, estamos atingindo outras realidades, como creches e alfabetização de crianças, as minhas atividades na área de comunicação tem ajudado no desenvolvimento dos projetos, favela da fumaça , favela do pantanal, tem um marco de violência. Eu não sou um padre de uma grande cidade apenas. Minha experiência vem das CEBS, a própria teologia da libertação, e a renovação carismática católica, tenho as ações sociais, mais de duas mil famílias atendidas, o conselho tutelar que atua junto a paróquia e a pastoral da criança, e a dimensão do samaritano com cestas básicas. 


\section{6) Como você foi inserido nesse ambiente midiático?}

No primeiro ano de ministério fui enviado para uma comunidade simples e a partir das missas de cura e libertação consegui ajudar ao povo, o trabalho com a pastoral da criança e os Vicentinos me ajudaram no início. Com as missas a Band me pediu para fazer uma missa para concorrer, com o padre Marcelo, mas eu neguei, apareceu um convite para fazer uma participação na rádio tropical me convidou para fazer uma chamada, essa fiz por uns dois anos na Rádio Tropical, mas não via como um ministério, mas eu achava que quando eu entrasse na vida midiática eu perderia minha vida social, estar com amigos, porque eu tinha medo de perder o direito de ir à padaria e ao mercado.

A partir da jornada mundial da juventude da Espanha, começamos a formar o grupo para ir para Espanha, fui fazer divulgação no Metro News com o jornal me abriram a possibilidade para falar em rádios na época, na rádio Dom Bosco em Fortaleza, eu gravava dez minutos de oração para eles, gravações que iriam ao ar todos os Domingos, quem deu o pontapé com links de entrevista para Rede Globo, Band e a Rede Teve, para promover a jornada, e tudo começou para promover a jornada, eu sempre achei que não tinha jeito para isso, mas eu não sou desse meio e não nasci nesse meio, mas Deus tem propósitos nessa área e tenho assistido muito, aprendido muito, e escuto quem produz nos bastidores, para entender como se comunicar com o povo, entender, luz, câmera e tudo estou aprendendo no dia a dia. A Teve Êxito com Liliane Ventura e a rede Século XXI e a Rede Católica da igreja que são as duas áreas de atuação.

\section{7) Quais são as suas considerações a respeito do ministério pastoral midiático efetivo?}

A importância da mídia para vida pastoral, precisamos entender a realidade de hoje as redes sociais, web, rádio, tv aberta e fechada. Como formador de opinião, compreendo que o ser humano e um ser social e tenho interesse de mudar a sociedade falando da fé e de Deus, tudo isso tem impacto na vida pastoral, todos os veículos de comunicação estão no dia a dia de todo cidadão, a internet vai a todos os pontos do pais, porque não atingir aqueles lugares de sombra, porque não atingir com a radio e a teve porque não atingir, com as rádios 
difusoras de Am e Fm, eu vejo como uma ferramenta fundamental para a ação pastoral, o negativo e o positivo de toda essa ação.

Eu não sei quem está me assistindo, mas eu compreendo que vou impactar alguém de uma forma ou de outra, quem não se interessa pelo assunto pode desenvolver um senso crítico. Sem perder a realidade daquele que é um ser social. Eu continuo indo à padaria perto da minha comunidade, faço almoço e janta na padaria e lanches e tenho o convívio na vida comum, circulando junto à comunidade no meu espaço pastoral, com a liberdade de caminhar com o povo tenho a ideia que esse ministério não é para estrelismo, não sou artista, atuo como padre, não pretendo ser artista. Fama e lama caminham juntas. Será que estimulamos o fanatismo, se existe idolatria, será que nós somos responsáveis por isso. Precisamos equilibrar fé e razão.

\section{8) Quais são as tecnologia que você usa para desenvolver suas atividades} ministeriais?

Radio, TV, twitter, Lapscope, Facebook, Redes Sociais. Etc.

\section{9) Quais as vantagens da mídia e as desvantagens para a pregação do evangelho?}

Não considero desvantagens todos os grandes Best Sellers falam de Jesus, e muito nem professam a religião, Jesus é o maior que já existiu, se eu levar Jesus assim estaremos formando uma sociedade melhor, vou pegar as referências de Jesus e tentar passar os ensinamentos de como viver uma sociedade melhor, levar conhecimento técnica para como viver uma vida de amor e um olhar sobre si e sobre o outro, e a maior de todas a justiça como lema, se estabelecer a justiça sobre a terra teremos uma sociedade melhor.

As desvantagens estão relacionadas com aqueles que não querem aceitar e entender, aquele que está inclinado as ações injustas do ser, se cerca do poder e do ter, para o materialismo do ser humano. 
10) O que é o poder religioso?

A capacidade de atingir a pessoa humana em todas as suas esferas, fazer o que é Divino e transcendental para conceituar o humano

\section{1) Como se deve exercer o poder religioso?}

Com muita responsabilidade, devo ser sério e tratar a pessoa como pessoa com dignidade valor e respeito, dar a liberdade da fé com respeito a pessoa humana.

\section{2) Como o poder religioso se relaciona com a mídia?}

Quantas vezes no nosso discurso as vezes falamos que a mídia é negativa problemática, mas ao mesmo tempo estamos dentro dela, como dizer que essa ferramenta é demoníaca, as vezes existe uma demonização e falam do que não sabem, essa ferramenta pode ser usada, são mais de 140 milhões de pessoas que podem ser atingidas com um programa de forma direta e de forma indireta, a pessoa vai visualizar o vídeo, vai reproduzir onde quiser, a formação da consciência logo a mídia não e um demônio, mas pode se tornar.

\section{3) Quais são as suas recomendações para não se envolver no abuso do poder midiático?}

Cautela sempre, uma das palavras, descrição, e colocar-se sempre como telespectador, o que eu quero receber em casa, como cristão ou o que você quer dar para os seus filhos, para a família, o que a família precisa, seja a formação de multiface o que a família precisa receber. $\mathrm{O}$ que precisamos oferecer para a família. 


\section{ENTREVISTA 04 - SE4}

\section{BLOCO 01 - PERFIL DO ENTREVISTADO}

Nome: SE4

Escolarização: Fiz a minha formação de seminarista, primeiro em Lavras, fui ainda menino. Depois 7 anos em Santa Catarina, mais tarde dois anos em Brusque, cursei filosofia, depois vim a Taubaté, depois fui para Hales Cornes, Winsconsin, onde estudei teologia e fiz cursos em Washington depois estudei aconselhamento pastoral, depois vários cursos de religiões comparada, fiz vários cursos de comunicação pela música e leitura da comunicação, pastoral da comunicação

Você possui ou participa:

Facebook: ( x ) Sim ( ) Não

Lista de discussão em comunidades virtuais: ( $\mathrm{x}$ )Sim ( ) Não

Participa de alguma comunidade virtual: ( x ) Sim ( ) Não

\section{1) Quem e você de acordo com suas atividades?}

Um sacerdote católico com 50 anos de atividade que decidiu anunciar o evangelho para as multidões, mas numa perspectiva ecumênica, tive influência de várias religiões, também através de meus estudos no Estados Unidos da América.

\section{2) Por que você acredita na sua atuação?}

Tenho apoio dos bispos e das pessoas, tenho apoio através das canções e artigos e livros que público, posso dizer que pelos frutos conhecereis, acredito que a opinião do povo e importante para meu trabalho.

\section{3) Fale sobre sua formação e capacitação para o seu trabalho.}

Fiz a minha formação de seminarista, primeiro em Lavras, fui ainda menino. Depois 7 anos em Santa Catarina, mais tarde dois anos em Brusque, cursei filosofia, depois vim a Taubaté, depois fui para Hales Cornes, Winsconsin, EUA, onde estudei teologia e fiz cursos em Washington depois estudei 
aconselhamento pastoral, depois vários curso de religiões comparada, fiz vários cursos de comunicação pela música e leitura da comunicação, pastoral da comunicação, cursos que buscavam para me capacitar na área, tive oportunidade de ver várias igrejas em vários países como os religiosos se comunicam e como o povo recebe a comunicação, criei o curso de pratica e crítica de comunicação na igreja, pertenço a ordem dos Padres Dehonianos, fui para o estados unidos pela formação de psicopedagogia.

\section{4) Quais são as suas atividades midiáticas?}

Eu dirigi por vinte anos a teve católica, criei programas de teologia e catequese em 3 tevês católicas, criei programas de rádio em mais de 20 emissoras, lecionei cursos de rádio e televisão, formei mais de 300 alunos na faculdade de teologia em Taubaté, onde fui professor por 32 anos e dirigi cursos mais de 100 em todo brasil e América Latina, sobre a capacidade do comunicador religioso e o impacto na comunicação, criei grupos de cantos, preparei mais de 10 maestros para fazer música religiosa e católica, trabalhei com música religiosa e ecumênica, e fiz muitos simpósios sobre a comunicação ecumênica, atividades sempre voltadas para a educação, eu sou professor e educador.

\section{5) Como é o seu cotidiano?}

Por 45 anos levantava as 5 e meia e deitava a meia noite, muito trabalho, cheguei a dar 8 conferencias por dia, fiquei doente, tive um AVC, diabetes, tive que diminuir bastante, recuperei a fala, recuperei o diabete e o câncer que foi controlado, hoje levanto pelas 6 e meia, pesquiso, estudo, escrevo, 3 a 4 horas de pesquisa, escrevo muito e leio muito sobre ecumenismo, psicologia, pedagogia, história, sociologia e comunicação, a partir dessas áreas escrevo meus livros. Não vou a televisão eles vêm a mim, dou muitas entrevistas, moro em são Paulo e Taubaté, assessoro padres que estudam comunicação, meu cotidiano é ensinar, pesquisar e escrever, também fazer radio, radio gravado, e mando para mais de 50 emissoras, que retransmitem. Programas curtos de cinco a dez minutos por programa. 


\section{6) Como você foi inserido nesse ambiente midiático?}

Descobriram que eu tinha talento, nunca pensei, até os 27 anos, que iria fazer mídia, eu queria ser educador, descobriram que eu cantava bem, que minhas músicas chegavam aos jovens, comecei a ser chamado para pregar, formei jovens para falar, me chamaram para falar nos estádios, para multidões, eu sou muito aceito, já cantei para 150 mil pessoas, muita gente chegou para aprender sobre como cantar e faze show como motivar a multidão, e isso me levou para a multidão, sempre fiz mídia católica, não me encantei com as grandes redes de televisão fiz uma opção de ser midiático religioso, quis trabalhar mais com o evangelho e editoras que publicassem temas religiosos, antes não havia editora que tinha interesse por assuntos religiosos, achei que deveria desenvolver a nossa mídia, para não ficar à mercê das grandes gravadoras, eu fiz essa opção e nunca mudei, achei que fui formado pela igreja, e não era justo passar meu talento para outros grupos.

Os motivadores, foram Dom Elder, Dom Paulo, irmã Dulce, Dom Luciano, grandes bispos conhecidos na igreja, cantei para quatro papas, fui a vários países para mostrar como o canto pode ajudar a orar e fazer catequese.

\section{7) Pensando no ministério midiático efetivo e atual, quais são as suas considerações a esse respeito?}

Parece que existe um esforço muito grande das lideranças religiosas, de formar melhor os padres e pastores, hoje a muita gente que estuda a comunicação direito, sociologia e psicologia. Pregadores que estão estudando muito, mas é preciso acentuar mais ainda a formação do pregador, há os que improvisam demais , os novos avivalistas que aparecem do nada que brincam de pregação há muitos pregadores despreparados vão encantados com o seu visual, valorizam demais aparecer na televisão e não falar em nome de suas igrejas, há muito individualismo, assumem a mídia como se fosse deles o microfone e não da sua igreja, ocupam o tempo todo quando há outros que também poderiam falar, há muitos que ocupam de 8 a dez horas por dia de televisão, minha critica as igrejas não estão conseguindo controlar seu pregadores famosos. 


\section{8) Quais são as tecnologias que você usa para desenvolver suas atividades ministeriais?}

Com o advento do computador temos mais de 30 instrumentos dentro do computador para fazer evangelização, ensinei isso para os alunos, mostrando as possibilidades da computação, como utilizar todos os veículos a sua disposição, mostrava os estúdios e gravações, o valor do som e da sonoridade, a importância dos templos para ensinar a falar no microfone e a repercutir, não só por show no palco, como do padre que usa o microfone e ensinar a usar técnicas de sonoridade e também visual, e também das capacidades de explorar as cores e os valores da televisão. Deve ficar claro que não pode ser uma televisão amadora, deve ser profissional e com muita ética, sem mentira, sem marketing e números falsos, isso acontece muito, reúne cinco mil, depois fala que tinha cinquenta mil, $150 \mathrm{mil}$, diz que tinha 5 milhões, tem vinte mil e fala que tem cem mil, a câmera só mostra um lado da igreja e passam isso para enganar o povo, isso tomou conta dos templos evangélicos e católicos, o fiel pensa que faz parte de uma igreja de 3 milhões quando na verdade só tem 200 mil, padres e pastores que vendem 30 mil e dizem que foi 3 milhões de livros que vendeu 3 mil e dizem que foi $30 \mathrm{mil}$, isso e desonesto e uma igreja assim não tem credibilidade e não tem chance de prosperar espiritualmente.

\section{9) Fale sobre sua atuação nas redes sociais.}

Tenho vários sites conduzidos por 50 pessoas, atinjo 500 mil pessoas, tenho a coragem de dizer que não sei sobre todos os assuntos, e tenho coragem de dizer que errei e vou corrigir, faço questão de corrigir se não foi bom, se a pessoa reclama, peço desculpas, nas redes sociais não pode ser mentira, deve ser verdadeira e didática, verdadeira e ética, indico Roger Olsen, Karen Armstrong, Baullmam, Jean Paul Baldrilar, leio livros de ateus, evangélicos e católicos, na área de comunicação, tenho mais de 250 livros nessa linha de comunicação, quase todos já estão traduzidos.

10) Quais as vantagens e as desvantagens sobre a mídia e a pregação do evangelho? 
A vantagem é que você atinge milhões de pessoas ou pequenas comunidades, você pode falar com essas pessoas com frequência, através do rádio, teve, revistas e livros, a capacidade de distribuir sua cultura e sua fé. A desvantagem é muito imprevista, intuitivo, sem profundidade, revistinhas com conteúdo muito ralo, você está dando sopa para o povo falta profundidade, poucos conseguem a profundidade com a facilidade de comunicar, são simplórios e não conseguem ser profundos, não estão dizendo nada, apenas estão para aparecer, diz que faz milagres e não se comprova, brincando de milagres e curas e de evangelizar, isso é fruto da falta de profundidade no púlpito, isso deixa vazio o coração dos fiéis.

\section{1) O que é o poder religioso?}

Uma espada de cinco pontas se você não fizer um bom uso vai machucar alguém, todas as vezes que você tem uma câmera um microfone, imprimir um livro, você não sabe o que você está dizendo pode criar um problema gravíssimo para a pessoa, que não tem cura, as vezes pode se ensinar o medo, orgulho, visões erradas da bíblia, com o poder na mão, pode se brincar de evangelizar, isso afeta e deturpa o legado do evangelho, e muito grande o número de pastores e preparados e padres ingênuos e depois dizem coisas que as pessoas saem dos templos com medo de Deus, pode ser um instrumento errado nas mãos erradas. Na maioria dos lugares, pregador errado, do jeito errado com o conteúdo errado.

\section{2) Como se deve exercer o poder religioso?}

Um exemplo: O papa Francisco, não pediu, estava quieto em Buenos aires, andando de guarda chuva e de metro, gostava de andar no meio do povo, tinha um carro muito simples, sempre escolheu ser pobre, quando o fizeram papa, por conselho do Dom Cláudio de São Paulo, um jesuíta e um franciscano, qual o nome devo dar para o Papa, o seu nome deve ser Francisco, você é pobre igual a Francisco, ele disse é mesmo, eu vou chamar Francisco, influência de um cardeal franciscano, e um jesuíta, é um modelo de misericórdia, se mistura com os pobres quer dialogo com todas as religiões, vai para o meio do povo, Ele escreveu o livro 
o nome de Deus é compaixão, estão se escrevendo muito sobre perdão, compaixão e misericórdia, estamos reinaugurando a era da compaixão, todas as igrejas estão buscando juntas, se existe uma prova que o ecumenismo pode funcionar é a compaixão. Se lutarmos contra a violência estava trilhando um novo caminho para o evangelho, a meu ver e a nova era da compaixão.

\section{3) Como o poder religioso se relaciona com a mídia?}

Com dificuldades, não sabem fazer uma mídia ecumênica, os católicos ainda tem dificuldades para se aproximarem dos protestantes, quase não acontece celebrações midiáticas juntos, não conseguimos usar o poder que a mídia tem de usar o dialogo religioso, temos medo de tirar os fiéis, quem tem uma boa catequese não perde fieis, se todos formam direito, vão ter dialogo e respeito, a mídia protestante está nas mãos de pentecostais, a teve aparecida é a mais aberta as outras tevês são muito fechadas, a gestão da teve aparecida, padres redentoristas, e leigos preparados é mais abertas.

\section{4) Quais as suas recomendações para não se envolver em situações de abuso do poder midiático?}

Espírito de pobreza a mídia não deve nos fazer ricos, pastor e padre que ficam ricos com a mídia dão mau testemunho. Repensar a teologia da prosperidade, é uma aberração do evangelho. Repensar o cuidado com os pobres. O Dizimo se torna uma imposição, não pode ser deve ser obediência. Repensar o papel dos padres e pastores midiáticos que aparecem demais e outros colegas não tem chance, a teve religiosa está nas mãos de famílias religiosas, Universal é de uma família, Renascer é de uma família, Igreja da graça, Igreja católica, Rede Vida é de uma família, Igreja mundial, uma família, está nas mãos de famílias fazem 30 anos que está nas mãos deles, isso é um feudo religioso, associação de igrejas e mais fácil, Record também família. A igreja existe para servir o povo, não para atender necessidades de famílias, estão ficando ricos e as igrejas pobres, igual futebol, poucos ricos e outros jogadores procurando emprego, pastores e padres estão sendo respeitados por seu ministério por alguns poucos estão dominando tudo. 


\section{APÊNDICE B}

\section{Respostas dos Pesquisados}

\begin{tabular}{|c|c|}
\hline \multicolumn{2}{|c|}{ Pergunta 01 - Quem e você de acordo com suas atividades? } \\
\hline SUJEITO & RESPOSTA \\
\hline SE1 & $\begin{array}{l}\text { Eu acredito na minha vocação e quero ser uma pessoa sensível } \\
\text { a realidade humana, principalmente a necessidade de escutar o } \\
\text { gemido humano. }\end{array}$ \\
\hline SE2 & $\begin{array}{l}\text { Sou pastor da Igreja Batista Bacacheri a } 27 \text { anos, sou professor } \\
\text { da faculdade Batista do Paraná, fui professor de curso de } \\
\text { Bacharel em Teologia, sou professor do Instituto Haggai. }\end{array}$ \\
\hline SE3 & $\begin{array}{l}\text { Eu acredito na atuação de Deus, Ele age como quem tem } \\
\text { autoridade, eu me permito para ser usado por Deus para } \\
\text { comunicar as boas novas, eu não teria a mesma desenvoltura } \\
\text { para comunicar em outras atividades, ser cristão é minha vida, } \\
\text { pertencer a igreja católica é minha vida, viver essa fé é minha } \\
\text { vida, nasci nessa religião. O creio no que eu faço, porque creio } \\
\text { na vida eterna e em Cristo. }\end{array}$ \\
\hline SE4 & $\begin{array}{l}\text { Um sacerdote católico com } 50 \text { anos de atividade que decidiu } \\
\text { anunciar o evangelho para as multidões, mas numa perspectiva } \\
\text { ecumênica, tive influência de várias religiões, também através } \\
\text { de meus estudos no Estados Unidos da América. }\end{array}$ \\
\hline
\end{tabular}

\begin{tabular}{|l|l|}
\hline Pergunta 02 - Por que você acredita na sua atuação? \\
\hline SUJEITO & $\begin{array}{l}\text { RESPOSTA } \\
\text { A vocação me levou para o estudo da teologia, eu estudei } \\
\text { teologia clássica eu me aprofundei fui fazer Mestrado e } \\
\text { Doutorado com ênfase em Missiologia nos EUA, a vocação me } \\
\text { levou para necessidade de abraçar uma vocação mais } \\
\text { acadêmica, para ser qualificado para vivencia da vocação, essa } \\
\text { teologia, e continuo estudando. }\end{array}$ \\
\hline SE2 & $\begin{array}{l}\text { Deus abre portas e promove oportunidades e dá dons para } \\
\text { promoção do seu reino, e estou atento as oportunidades que } \\
\text { Deus dá, eu não acredito que eu devo fazer as coisas } \\
\text { acontecerem ao meu favor, eu preciso ver o que Deus está } \\
\text { fazendo e se unir ao que ele está fazendo }\end{array}$ \\
\hline SE3 & $\begin{array}{l}\text { Eu acredito na atuação de Deus, Ele age como quem tem } \\
\text { autoridade, eu me permito para ser usado por Deus para } \\
\text { comunicar as boas novas, eu não teria a mesma desenvoltura } \\
\text { para comunicar em outras atividades, ser cristão é minha vida, } \\
\text { pertencer a igreja católica é minha vida, viver essa fé é minha } \\
\text { vida, nasci nessa religião. O creio no que eu faço, porque creio } \\
\text { na vida eterna e em Cristo. }\end{array}$ \\
\hline SE4 & $\begin{array}{l}\text { Tenho apoio dos bispos e das pessoas, tenho apoio através das } \\
\text { cançôes e artigos e livros que público, posso dizer que pelos } \\
\text { frutos conhecereis, acredito que a opinião do povo e importante } \\
\text { para meu trabalho. }\end{array}$ \\
\hline
\end{tabular}




\begin{tabular}{|l|l|}
\hline Pergunta 03: Fale sobre sua formação e capacitação para o seu trabalho. \\
\hline SUJEITO & RESPOSTA \\
\hline SE1 & $\begin{array}{l}\text { A vocação me levou para o estudo da teologia, eu estudei } \\
\text { teologia clássica eu me aprofundei fui fazer Mestrado e } \\
\text { Doutorado com ênfase em Missiologia nos EUA, a vocação me } \\
\text { levou para necessidade de abraçar uma vocação mais } \\
\text { acadêmica, para ser qualificado para vivencia da vocação, essa } \\
\text { teologia, e continuo estudando. }\end{array}$ \\
\hline SE2 & $\begin{array}{l}\text { Engenheiro mecânico, teologia na graduação, mestrado e } \\
\text { doutorado no estados unidos, em 1988 cheguei no Brasil sempre } \\
\text { aperfeiçoando, e a igreja local sempre foi prioridade junto com } \\
\text { o ensino teológico, a igreja sempre possibilitou esse parceria. }\end{array}$ \\
\hline SE3 & $\begin{array}{l}\text { Colegial básico e técnico em eletrônica, filosofia instituto Boa } \\
\text { Ventura e teologia na PUC São Paulo, fiz direito e também um } \\
\text { aperfeiçoamento em teologia para poder trabalhar na área } \\
\text { pastoral. Fiz vários cursos paralelos, para exercer funções na } \\
\text { mídia, fiz um curso de direito. }\end{array}$ \\
\hline$\frac{5}{\stackrel{N}{N}}$ & $\begin{array}{l}\text { Fiz a minha formação de seminarista, primeiro em Lavras, fui } \\
\text { ainda menino. Depois 7 anos em Santa Catarina, mais tarde dois } \\
\text { anos em Brusque, cursei filosofia, depois vim a Taubaté, depois } \\
\text { fui para Hales Cornes, Winsconsin, EUA, onde estudei teologia } \\
\text { e fiz cursos em Washington depois estudei aconselhamento } \\
\text { pastoral, depois vários cursos de religiões comparada, fiz vários } \\
\text { cursos de comunicação pela música e leitura da comunicação, } \\
\text { pastoral da comunicação, cursos que buscavam para me } \\
\text { capacitar na área }\end{array}$
\end{tabular}

\begin{tabular}{|l|l|}
\hline Pergunta 04 - Quais são as suas atividades midiáticas? \\
\hline SUJEITO & $\begin{array}{l}\text { O exercício da vocação te torna uma pessoa pública, minha } \\
\text { função tem a ver com o microfone, com a comunicação, isso } \\
\text { significa estar no circuito das palestras de eventos no Brasil e } \\
\text { fora do Brasil. }\end{array}$ \\
\hline \multirow{5}{*}{ SE2 } & $\begin{array}{l}\text { Programa de rádio, programa de televisão para internet, } \\
\text { atividade devocionais na internet, vidanet, estão disponíveis na } \\
\text { rede, tenho as redes sociais, Facebook, Twitter, vídeos } \\
\text { pequenos para os membros e se tornam públicos, vídeos rápidos } \\
\text { para temas de época. Jornais e revistas publicadas } \\
\text { semanalmente para igreja e jornal mensal, tudo disponível na } \\
\text { internet, tem o site da igreja onde apresenta os programas da } \\
\text { igreja. }\end{array}$ \\
\hline SE3 & $\begin{array}{l}\text { Gravações para programas de bênçãos e orações, desenvolvo } \\
\text { um trabalho de apresentações e na TV Século XXI um novo } \\
\text { programa, na rede católica da igreja, tem o programa fé na vida } \\
\text { e com a palavra todas as manhãs e também o noite de louvor, a } \\
\text { maioria dos programas são ao vivo. }\end{array}$ \\
\hline SE4 & $\begin{array}{l}\text { Eu dirigi por vinte anos a teve católica, criei programas de } \\
\text { teologia e catequese em } 3 \text { tevês católicas, criei programas de } \\
\text { rádio em mais de 20 emissoras, lecionei cursos de rádio e }\end{array}$ \\
\hline
\end{tabular}




\begin{tabular}{|l|l|}
\hline televisão, formei mais de 300 alunos na faculdade de teologia \\
em Taubaté, onde fui professor por 32 anos e dirigi cursos mais \\
de 100 em todo brasil e América Latina, sobre a capacidade do \\
comunicador religioso e o impacto na comunicação, criei \\
grupos de cantos, preparei mais de 10 maestros para fazer \\
música religiosa e católica, trabalhei com música religiosa e \\
ecumênica, e fiz muitos simpósios sobre a comunicação \\
ecumênica, atividades sempre voltadas para a educação, eu sou \\
professor e educador.
\end{tabular}

\begin{tabular}{|c|c|}
\hline \multicolumn{2}{|c|}{ Pergunta 05 - Como é o seu cotidiano? } \\
\hline SUJEITO & RESPOSTA \\
\hline SE1 & $\begin{array}{l}\text { A atividade pastoral e caótica, uma das prioridades, mistério } \\
\text { pastoral, comunicação do, relacionamento com pessoas, gestão } \\
\text { de igrejas, palestra e escrever, preparo de material, publicação } \\
\text { de material, a aliança crista evangélica brasileira, tem a ver com } \\
\text { a questão de comunicação. }\end{array}$ \\
\hline SE2 & $\begin{array}{l}\text { Um caos organizado, tenho uma agenda básica, que tento } \\
\text { seguir, trabalho muito na igreja, dou expediente, preparo } \\
\text { sermão, segunda feira, é um dia administrativo, financeiro, } \\
\text { secretaria, telefonemas, terça feita reunião com colegiado de } \\
\text { pastores, discipulado com os pastores, para dar uma sequência } \\
\text { nas decisões da reunião anterior, terça feira tem uma reunião de } \\
\text { oração com a equipe, a noção de organização é fundamental, } \\
\text { se você deixar todos querem fazer a sua agenda, tenho } \\
\text { atendimento no fim do dia da terça feira a noite faço visitas para } \\
\text { as família da igreja, quarta-feira, preparo de sermão na parte da } \\
\text { manhã, quarta a tarde gabinete pastoral, quarta à noite com a } \\
\text { família, as viagens são programadas pelo menos uma vez por } \\
\text { mês, as vezes preciso fazer uma gestão de horário por causa das } \\
\text { viagens, almoços durante a semana são aproveitadas para } \\
\text { reunião, quinta feira o dia inteiro para preparar o sermâ, } \\
\text { aproveito para almoçar com alguém, não escrevo o sermão } \\
\text { inteiro, tem um roteiro a seguir na média de } 4 \text { a } 5 \text { páginas, todo } \\
\text { esquema ligado com Power Point, sexta feira dia de folga, as } \\
\text { vezes um compromisso sexta à noite, normalmente tenho um } \\
\text { dia de folga na sexta, tenho enxaqueca e procuro não tirar um } \\
\text { dia de folga na segunda, sábado tento dar um dia de folga, se } \\
\text { consigo cumprir com todas as atividades procuro dar o Sábado } \\
\text { livre, Domingo é o principal dia de atividades, cultos, no sábado } \\
\text { estou em casa, sábado à tarde tiro livre, e domingo dia inteiro de } \\
\text { trabalho. }\end{array}$ \\
\hline SE3 & $\begin{array}{l}\text { Eu sou pároco, tenho uma paróquia e uma capela, tenho um } \\
\text { instituto e sou o vice-presidente, Amigos da Fé, organização } \\
\text { com cunho pedagógico, cuida de crianças que são filhos de pais } \\
\text { portadores de vírus HIV, estamos atingindo outras realidades, } \\
\text { como creches e alfabetização de crianças, as minhas atividades } \\
\text { na área de comunicação tem ajudado no desenvolvimento dos } \\
\text { projetos, favela da fumaça, favela do pantanal, tem um marco }\end{array}$ \\
\hline
\end{tabular}




\begin{tabular}{|l|l|}
\hline & $\begin{array}{l}\text { de violência. Eu não sou um padre de uma grande cidade } \\
\text { apenas. Minha experiência vem das CEBS, a própria teologia da } \\
\text { libertação, e a renovação carismática católica, tenho as ações } \\
\text { sociais, mais de duas mil famílias atendidas, o conselho tutelar } \\
\text { que atua junto a paróquia e a pastoral da criança, e a dimensão } \\
\text { do samaritano com cestas básicas. }\end{array}$ \\
\hline $\begin{array}{l}\text { Por } 45 \text { anos levantava as } 5 \text { e meia e deitava a meia noite, muito } \\
\text { trabalho, cheguei a dar } 8 \text { conferencias por dia, fiquei doente, } \\
\text { tive um AVC, diabetes, tive que diminuir bastante, recuperei a } \\
\text { fala, recuperei o diabete e o câncer que foi controlado, hoje } \\
\text { levanto pelas } 6 \text { e meia, pesquiso, estudo, escrevo, } 3 \text { a } 4 \text { horas de } \\
\text { pesquisa, escrevo muito e leio muito sobre ecumenismo, } \\
\text { psicologia, pedagogia, história, sociologia e comunicação, a } \\
\text { partir dessas áreas escrevo meus livros. Não vou a televisão eles } \\
\text { vem a mim, dou muitas entrevistas, moro em são Paulo e } \\
\text { Taubaté, assessoro padres que estudam comunicação, meu } \\
\text { cotidiano é ensinar, pesquisar e escrever, também fazer radio, } \\
\text { radio gravado, e mando para mais de 50 emissoras, que } \\
\text { retransmitem. Programas curtos de cinco a dez minutos por } \\
\text { programa. }\end{array}$ \\
\hline
\end{tabular}

\begin{tabular}{|l|l|}
\hline \multicolumn{3}{|l|}{ Pergunta 06 - Como você foi inserido nesse ambiente midiático? } \\
\hline SUJEITO & RESPOSTA \\
\hline SE1 & $\begin{array}{l}\text { Como você entrou nesse ambiente de comunicação? Alguém } \\
\text { me colocou, a vocação me leva para busca de formação e a essa } \\
\text { busca me leva a me posicionar no contexto da realidade em que } \\
\text { eu vivo, a vocação me insere, uma das primeira inserções foi } \\
\text { através da ABU }\end{array}$ \\
\hline \multirow{3}{\text{SE2}}{} & $\begin{array}{l}\text { Não tem escolha, a situação vai te levando a fazer e a } \\
\text { desenvolver aspectos na comunicação, vai escrevendo textos, } \\
\text { vai sendo puxado para o ambiente da comunicação, } \\
\text { normalmente não existe uma intencionalidade, quando você } \\
\text { percebe já estava fazendo. }\end{array}$ \\
\hline
\end{tabular}

308 A Aliança Bíblica Universitária do Brasil (ABUB) é uma organização missionária evangélica que existe para compartilhar o Evangelho de Jesus Cristo nas escolas e universidades brasileiras, através da iniciativa dos próprios estudantes. O treinamento e formação de estudantes e profissionais, visando o testemunho cristão e o serviço à Igreja e à sociedade, completam nossa missão. Nossa visão: Estudantes que formam comunidades de discípulos, transformados pelo Evangelho, e que impactem o mundo estudantil, a igreja e a sociedade para a glória de Cristo. Nossos objetivos: A evangelização dos secundaristas, universitários e profissionais, por intermédio da comunicação da mensagem do evangelho e da demonstração prática da vivência cristã, objetivando sua submissão ao senhorio de Jesus Cristo. O desenvolvimento dos secundaristas, universitários e profissionais rumo à maturidade do ser humano integral em Cristo Jesus, nos aspectos pessoal e comunitário, de forma a assumirem sua responsabilidade no âmbito da família, da igreja e da sociedade. A realização de missão e serviço pelos estudantes e profissionais, mediante a descoberta de seu lugar de chamado por Deus, na Igreja e no mundo. Assistência ao estudante e à comunidade, visando ao desenvolvimento do homem e da mulher, como manifestação do amor de Deus, em Cristo. Em 2012 encerramos o ano com 107 grupos filiados à ABUB (88 grupos de estudantes universitários, 14 de ensino médio e 5 de profissionais), em 91 diferentes cidades brasileiras. http://www.abub.org.br/quem-somos 12122015 


\begin{tabular}{|c|c|}
\hline SE3 & $\begin{array}{l}\text { A partir da jornada mundial da juventude da Espanha, } \\
\text { começamos a formar o grupo para ir para Espanha, fui fazer } \\
\text { divulgação no Metro News com o jornal me abriram a } \\
\text { possibilidade para falar em rádios na época, na rádio Dom } \\
\text { Bosco em Fortaleza, eu gravava dez minutos de oração para } \\
\text { eles, gravações que iriam ao ar todos os Domingos, quem deu o } \\
\text { pontapé com links de entrevista para Rede Globo, Band e a } \\
\text { Rede Teve, para promover a jornada, e tudo começou para } \\
\text { promover a jornada, eu sempre achei que não tinha jeito para } \\
\text { isso, mas eu não sou desse meio e não nasci nesse meio, mas } \\
\text { Deus tem propósitos nessa área e tenho assistido muito, } \\
\text { aprendido muito, e escuto quem produz nos bastidores, para } \\
\text { entender como se comunicar com o povo, entender, luz, câmera } \\
\text { e tudo estou aprendendo no dia a dia. A Teve Êxito com Liliane } \\
\text { Ventura e a rede Século XXI e a Rede Católica da igreja que } \\
\text { são as duas áreas de atuação. }\end{array}$ \\
\hline SE4 & $\begin{array}{l}\text { Descobriram que eu tinha talento, nunca pensei, até os } 27 \text { anos, } \\
\text { que iria fazer mídia, eu queria ser educador, descobriram que eu } \\
\text { cantava bem, que minhas músicas chegavam aos jovens, } \\
\text { comecei a ser chamado para pregar, formei jovens para falar, } \\
\text { me chamaram para falar nos estádios, para multidões, eu sou } \\
\text { muito aceito, já cantei para } 150 \text { mil pessoas, muita gente chegou } \\
\text { para aprender sobre como cantar e faze show como motivar a } \\
\text { multidão, e isso me levou para a multidão, sempre fiz mídia } \\
\text { católica, não me encantei com as grandes redes de televisão fiz } \\
\text { uma opção de ser midiático religioso, quis trabalhar mais com o } \\
\text { evangelho e editoras que publicassem temas religiosos, antes } \\
\text { não havia editora que tinha interesse por assuntos religiosos, } \\
\text { achei que deveria desenvolver a nossa mídia, para não ficar à } \\
\text { mercê das grandes gravadoras, eu fiz essa opção e nunca mudei, } \\
\text { achei que fui formado pela igreja, e não era justo passar meu } \\
\text { talento para outros grupos. } \\
\text { Os motivadores, foram Dom Elder, Dom Paulo, irmã Dulce, } \\
\text { Dom Luciano, grandes bispos conhecidos na igreja, cantei para } \\
\text { quatro papas, fui a vários países para mostrar como o canto } \\
\text { pode ajudar a orar e fazer catequese. }\end{array}$ \\
\hline
\end{tabular}

\begin{tabular}{|l|l|}
\hline $\begin{array}{l}\text { Pergunta 07 - Pensando no ministério midiático efetivo e atual, quais são as } \\
\text { suas considerações a esse respeito? }\end{array}$ \\
\hline SUJEITO & RESPOSTA \\
\hline \multirow{5}{*}{ SE1 } & $\begin{array}{l}\text { A questão fundamental é o evangelho, a fé, a crença de que que o } \\
\text { evangelho que faz diferença na vida das pessoas e fundamental } \\
\text { para todos, esse encontro do evangelho que te ajuda a viver, e } \\
\text { fundamento para entender o teu jeito de se posicionar na } \\
\text { sociedade, a grande pergunta e desenvolver um ministério } \\
\text { pastoral comunitário, esse evangelho tem uma dimensão, bíblica } \\
\text { quando uma dimensão comunitária pública, ele gera uma vida } \\
\text { que faca diferença, se expressa em comunidade mas tem uma } \\
\text { dimensão, quais são as peças que a gente junta no ministério }\end{array}$ \\
\hline
\end{tabular}




\begin{tabular}{|c|c|}
\hline & $\begin{array}{l}\text { pastoral, uma boa formação, ele precisa espiritualidade e precisa } \\
\text { de testemunho público e boa gestão, nossa igrejas se tornam } \\
\text { grandes e nesse fato se tornam vítimas do mercado, precisa ser } \\
\text { desenvolvida uma resistência ao mercado. Essa formação e uma } \\
\text { espiritualidade solida e que vai consolidar seu testemunho. } \\
\text { O testemunho do evangelho tem pouco de uma ética pública, tem } \\
\text { muito mais do mesmo, ela precisa vencer o mercado, a gestão vai } \\
\text { te ajudar a vencer o equilíbrio, o ministério pastoral hoje é } \\
\text { complexo, não se pode ceder ao mercado e a cultura e não se } \\
\text { pode perder a relevância, cada geração precisa enfrentar seus } \\
\text { desafios. }\end{array}$ \\
\hline SE2 & $\begin{array}{l}\text { O desafio do ministério pastoral é não perder a pessoalidade, não } \\
\text { se pode ignorar as mídias o fator da digitalização da vida e ao } \\
\text { mesmo tempo não pode fazer de conta que somos feitos de chip e } \\
\text { de plástico, o mundo digitalizado não substitui o carinho o afeto, } \\
\text { o caminhar na praia, o contato com a esposa e os filhos, a vida } \\
\text { digital não pode substituir os relacionamentos, é fácil refletir a } \\
\text { sociedade impessoal, que em cinco mil amigos nas redes sociais e } \\
\text { não tem amigo de fato, se a igreja não é lugar para compartilhar } \\
\text { sobre a minha dor, se não posso falar sobre o que está } \\
\text { acontecendo comigo, na igreja, é qualquer outra coisa menos } \\
\text { igreja. }\end{array}$ \\
\hline SE3 & $\begin{array}{l}\text { Eu não sei quem está me assistindo, mas eu compreendo que vou } \\
\text { impactar alguém de uma forma ou de outra, quem não se } \\
\text { interessa pelo assunto pode desenvolver um senso crítico. Sem } \\
\text { perder a realidade daquele que é um ser social. Eu continuo indo } \\
\text { à padaria perto da minha comunidade, faço almoço e janta na } \\
\text { padaria e lanches e tenho o convívio na vida comum, circulando } \\
\text { junto à comunidade no meu espaço pastoral, com a liberdade de } \\
\text { caminhar com o povo tenho a ideia que esse ministério não é para } \\
\text { estrelismo, não sou artista, atuo como padre, não pretendo ser } \\
\text { artista. Fama e lama caminham juntas. Será que estimulamos o } \\
\text { fanatismo, se existe idolatria, será que nós somos responsáveis } \\
\text { por isso. Precisamos equilibrar fé e razão. }\end{array}$ \\
\hline SE4 & $\begin{array}{l}\text { Parece que existe um esforço muito grande das lideranças } \\
\text { religiosas, de formar melhor os padres e pastores, hoje a muita } \\
\text { gente que estuda a comunicação direito, sociologia e psicologia. } \\
\text { Pregadores que estão estudando muito, mas é preciso acentuar } \\
\text { mais ainda a formação do pregador, há os que improvisam } \\
\text { demais, os novos avivalistas que aparecem do nada que brincam } \\
\text { de pregação há muitos pregadores despreparados vão encantados } \\
\text { com o seu visual, valorizam demais aparecer na televisão e não } \\
\text { falar em nome de suas igrejas, há muito individualismo, assumem } \\
\text { a mídia como se fosse deles o microfone e não da sua igreja, } \\
\text { ocupam o tempo todo quando há outros que também poderiam } \\
\text { falar, há muitos que ocupam de } 8 \text { a dez horas por dia de televisão, } \\
\text { minha critica as igrejas não estão conseguindo controlar seu } \\
\text { pregadores famosos. }\end{array}$ \\
\hline
\end{tabular}




\begin{tabular}{|c|c|}
\hline \multicolumn{2}{|c|}{$\begin{array}{l}\text { Pergunta } 08 \text { - Quais são as tecnologias que você usa para desenvolver suas } \\
\text { atividades ministeriais? }\end{array}$} \\
\hline SUJEITO & RESPOSTA \\
\hline SE1 & $\begin{array}{l}\text { A escrita tem sido a principal ferramenta o microfone, as redes } \\
\text { sociais uso pouco, tem uma coisa de geração eu sou da geração } \\
\text { da palestra, da escrita, do microfone, e estou enfrentando o } \\
\text { desafio de se converter. Eu uso Iphone, computador, Tablet, } \\
\text { máquina fotográfica, filmadora. } \\
\text { Quais são as suas atuações nas redes sociais, tenho sido mais } \\
\text { promovido do que me promover, a ultimato tem divulgado } \\
\text { minhas entrevistas com os pais da missão integral, essas } \\
\text { atividades de vídeo, estou tentando ampliar, na igreja usa mais e } \\
\text { mais tecnologia. }\end{array}$ \\
\hline SE2 & $\begin{array}{l}\text { Computador, Redes Sociais, Tablet, Power Point, Vídeos, } \\
\text { Telefone Celular. Eu resisto usar as mídias para auto promoção, } 3 \\
\text { vezes por dia um post sobre o indivíduo, que a foto dele é maior } \\
\text { do que a mensagem, a auto promoção, e teológico, se você tem } \\
\text { efésios } 4 \text { como base de sua teologia, você vai entender que a o } \\
\text { ministério e da igreja. Caso contrário vai divulgar a pessoa }\end{array}$ \\
\hline SE3 & Radio, TV, twitter, Lapscope, Facebook, Redes Sociais. Etc. \\
\hline SE4 & $\begin{array}{l}\text { Com o advento do computador temos mais de } 30 \text { instrumentos } \\
\text { dentro do computador para fazer evangelização, ensinei isso para } \\
\text { os alunos, mostrando as possibilidades da computação, como } \\
\text { utilizar todos os veículos a sua disposição, mostrava os estúdios e } \\
\text { gravações, o valor do som e da sonoridade, a importância dos } \\
\text { templos para ensinar a falar no microfone e a repercutir, não só } \\
\text { por show no palco, como do padre que usa o microfone e ensinar } \\
\text { a usar técnicas de sonoridade e também visual, e também das } \\
\text { capacidades de explorar as cores e os valores da televisão. } \\
\text { Deve ficar claro que não pode ser uma televisão amadora, deve } \\
\text { ser profissional e com muita ética, sem mentira, sem marketing e } \\
\text { números falsos, isso acontece muito, reúne cinco mil, depois fala } \\
\text { que tinha cinquenta mil, } 150 \text { mil, diz que tinha } 5 \text { milhões, tem } \\
\text { vinte mil e fala que tem cem mil, a câmera só mostra um lado da } \\
\text { igreja e passam isso para enganar o povo, isso tomou conta dos } \\
\text { templos evangélicos e católicos, o fiel pensa que faz parte de uma } \\
\text { igreja de } 3 \text { milhões quando na verdade só tem } 200 \text { mil, padres e } \\
\text { pastores que vendem } 30 \text { mil e dizem que foi } 3 \text { milhões de livros } \\
\text { que vendeu } 3 \text { mil e dizem que foi } 30 \text { mil, isso e desonesto e uma } \\
\text { igreja assim não tem credibilidade e não tem chance de prosperar } \\
\text { espiritualmente. }\end{array}$ \\
\hline
\end{tabular}

\begin{tabular}{|l|l|}
\hline \multicolumn{2}{|l|}{ Pergunta 09 Fale sobre sua atuação nas redes sociais. } \\
\hline SUJEITO & RESPOSTA \\
\hline SE1 & $\begin{array}{l}\text { Tenho sido mais promovido do que me promover, a ultimato tem } \\
\text { divulgado minhas entrevistas com os pais da missão integral, } \\
\text { essas atividades de vídeo, estou tentando ampliar, na igreja usa } \\
\text { mais e mais tecnologia. }\end{array}$ \\
\hline SE2 & Programa de rádio, programa de televisão para internet, atividade \\
\hline
\end{tabular}




\begin{tabular}{|l|l|}
\hline SE3 & $\begin{array}{l}\text { devocionais na internet, vidanet, estão disponíveis na rede, tenho } \\
\text { as redes sociais, Facebook, twitter, vídeos pequenos para os } \\
\text { membros e se tornam públicos. }\end{array}$ \\
\hline $\begin{array}{l}\text { A importância da mídia para vida pastoral, precisamos entender a } \\
\text { realidade de hoje as redes sociais, web, rádio, tv aberta e fechada. } \\
\text { Como formador de opinião, compreendo que o ser humano e um } \\
\text { ser social e tenho interesse de mudar a sociedade falando da é e } \\
\text { de Deus, tudo isso tem impacto na vida pastoral, todos os } \\
\text { veículos de comunicação estão no dia a dia de todo cidadão, a } \\
\text { internet vai a todos os pontos do pais, porque não atingir aqueles } \\
\text { lugares de sombra, porque não atingir com a radio e a teve } \\
\text { porque não atingir. }\end{array}$ \\
\hline $\begin{array}{l}\text { Tenho vários sites conduzidos por 50 pessoas, atinjo 500 mil } \\
\text { pessoas, tenho a coragem de dizer que não sei sobre todos os } \\
\text { assuntos, e tenho coragem de dizer que errei e vou corrigir, faço } \\
\text { questão de corrigir se não foi bom, se a pessoa reclama, peço } \\
\text { desculpas, nas redes sociais não pode ser mentira, deve ser } \\
\text { verdadeira e didática, verdadeira e ética, indico Roger Olsen, } \\
\text { Karen Armstrong, Baullmam, Jean Paul Baldrilar, leio livros de } \\
\text { ateus, evangélicos e católicos, na área de comunicação, tenho } \\
\text { mais de 250 livros nessa linha de comunicação, quase todos já } \\
\text { estão traduzidos. }\end{array}$ \\
\hline \multirow{5}{*}{}
\end{tabular}

Pergunta 10 - Quais as vantagens e as desvantagens sobre a mídia e a pregação do evangelho?

\begin{tabular}{|l|l|}
\hline SUJEITO & RESPOSTA \\
\hline
\end{tabular}

No ponto de vista teológico a gente vive em vantagens e desvantagens, cidadão do reino dos céus e do reino encarnado. Cada tempo e cada época precisa fazer essa leitura, período de anjos e demônios, nesse sentido não se demoniza o mundo de hoje e santifica o mundo de ontem.

SE1

Tem desafios que precisam ser respondidos com as ferramentas de nossa época e não com o instrumental de ontem. Não adianta dizer que vivemos em uma sociedade liquida, precisamos aprender a se comunicar com essa sociedade. Precisamos aprender a nos comunicar no padrão do Twitter.

A desvantagens é a falta de pessoalidade e a vantagens é a possibilidade de alcançar pessoas em todos os lugares do mundo, entrar em lugares inimagináveis, que não tem a limitação do

SE2 tempo e do espaço, o grande desafio é o como fazer o acompanhamento dos relacionamentos, as vezes se diz que a mídia é demoníaca, a mídia é amoral, não tem identidade, nós é que damos a característica moral e ética, como nós usamos é que vai definir a moral.

\begin{tabular}{|l|l|} 
& vai definir a moral. \\
\hline SE3 & $\begin{array}{l}\text { Não considero desvantagens todos os grandes Best Sellers falam } \\
\text { já existiu, se eu levar Jesus assim estaremos formando uma } \\
\text { sociedade melhor, vou pegar as referências de Jesus e tentar } \\
\text { passar os ensinamentos de como viver uma sociedade melhor, }\end{array}$ \\
\hline
\end{tabular}




\begin{tabular}{|c|c|}
\hline & $\begin{array}{l}\text { levar conhecimento técnica para como viver uma vida de amor e } \\
\text { um olhar sobre si e sobre o outro, e a maior de todas a justiça } \\
\text { como lema, se estabelecer a justiça sobre a terra teremos uma } \\
\text { sociedade melhor. } \\
\text { As desvantagens estão relacionadas com aqueles que não querem } \\
\text { aceitar e entender, aquele que está inclinado as ações injustas do } \\
\text { ser, se cerca do poder e do ter, para o materialismo do ser } \\
\text { humano. }\end{array}$ \\
\hline SE4 & $\begin{array}{l}\text { A vantagem é que você atinge milhões de pessoas ou pequenas } \\
\text { comunidades, você pode falar com essas pessoas com frequência, } \\
\text { através do rádio, teve, revistas e livros, a capacidade de distribuir } \\
\text { sua cultura e sua fé. A desvantagem é muito imprevisto, intuitivo, } \\
\text { sem profundidade, revistinhas com conteúdo muito ralo, você } \\
\text { está dando sopa para o povo falta profundidade, poucos } \\
\text { conseguem a profundidade com a facilidade de comunicar, são } \\
\text { simplórios e não conseguem ser profundos, não estão dizendo } \\
\text { nada, apenas estão para aparecer, diz que faz milagres e não se } \\
\text { comprova, brincando de milagres e curas e de evangelizar, isso é } \\
\text { fruto da falta de profundidade no púlpito, isso deixa vazio o } \\
\text { coração dos fiéis. }\end{array}$ \\
\hline
\end{tabular}

\begin{tabular}{|c|c|}
\hline \multicolumn{2}{|c|}{ Pergunta 11 - O que é o poder religioso? } \\
\hline SUJEITO & RESPOSTA \\
\hline SE1 & $\begin{array}{l}\text { Poder espiritual é o mais sensível dos poderes, porque ele lida } \\
\text { com o transcendente, não existe atuação publica que não tenha } \\
\text { uma dimensão do poder, qualquer atuação publica comunitária } \\
\text { implica no poder, o exercício do ministério pastoral é um } \\
\text { exercício de poder, essa é a realidade, não se pode viver a ilusão } \\
\text { de que não queremos caminhar no uso do poder, falar é poder, } \\
\text { caminhar é poder, o poder religioso evoca o transcendente e por } \\
\text { outro lado envolve o emocional o aspecto vulnerável da vida da } \\
\text { pessoa, você fazer uso dessa autoridade espiritual traz } \\
\text { consequências diversas. }\end{array}$ \\
\hline SE2 & $\begin{array}{l}\text { Em termos espirituais é toda a manifestação do poder de Deus, do } \\
\text { Espirito Santo do sobrenatural, o que todo ser humano anseia } \\
\text { mesmo sem saber, o poder religioso é o grande anseio do ser } \\
\text { humano. Sem o sobrenatural de Deus o ser humano cria } \\
\text { manifestações para demonstrar o poder, é a manifestação } \\
\text { negativa do poder religioso, um líder carismático pode usar a } \\
\text { religião para se auto promover, o poder que nos levou as cruzadas } \\
\text { e atualmente leva a exploração, falta o poder religioso verdadeiro } \\
\text { que é a ação do Espirito Santo, o ser humano tenta produzir. }\end{array}$ \\
\hline SE3 & $\begin{array}{l}\text { A capacidade de atingir a pessoa humana em todas as suas } \\
\text { esferas, fazer o que é Divino e transcendental para conceituar o } \\
\text { humano. }\end{array}$ \\
\hline SE4 & $\begin{array}{l}\text { Uma espada de cinco pontas se você não fizer um bom uso vai } \\
\text { machucar alguém, todas as vezes que você tem uma câmera um } \\
\text { microfone, imprimir um livro, você não sabe o que você está } \\
\text { dizendo pode criar um problema gravíssimo para a pessoa, que }\end{array}$ \\
\hline
\end{tabular}




\begin{tabular}{|l|l|}
\hline não tem cura, as vezes pode se ensinar o medo, orgulho, visões \\
erradas da bíblia, com o poder na mão , pode se brincar de \\
evangelizar, isso afeta e deturpa o legado do evangelho, e muito \\
grande o número de pastores e preparados e padres ingênuos e \\
depois dizem coisas que as pessoas saem dos templos com medo \\
de Deus, pode ser um instrumento errado nas mãos erradas. Na \\
maioria dos lugares, pregador errado, do jeito errado com o \\
conteúdo errado.
\end{tabular}

\begin{tabular}{|l|l|}
\hline Pergunta 12 - Como o poder religioso se relaciona com a mídia? \\
\hline SUJEITO & RESPOSTA \\
\hline SE1 poder religioso precisa subverter a mídia influenciando e \\
dando pautas para uma agenda não contraditória. A mídia é como \\
o quarto poder, a mídia não é neutra, ela precisa ser descortinada, \\
precisa revelar a serviço de quem ela está. O evangelho diz para a \\
mídia a serviço de quem ela está, porque a essência do Evangelho \\
é verdade e justiça. A mídia precisa ser denunciada quando está a \\
serviço da exploração e da riqueza, basicamente o poder \\
religioso, precisa denunciar e precisa conseguir anunciar o \\
evangelho para a necessidade de uma sociedade justa, onde a \\
verdade seja importante, onde o pobre seja protegido, o \\
evangelho precisa ajudar a mídia a ter esse olhar. A mentira \\
prevalece na sociedade atual, a mentira e um componente político \\
atual, o evangelho deve ajudar a mídia a vencer a mentira e \\
proclamar a justiça e a verdade.
\end{tabular}




\begin{tabular}{|c|c|}
\hline \multicolumn{2}{|c|}{$\begin{array}{l}\text { Pergunta } 13 \text { - Quais as suas recomendações para não se envolver em } \\
\text { situações de abuso do poder midiático? }\end{array}$} \\
\hline SUJEITO & RESPOSTA \\
\hline SE1 & $\begin{array}{l}\text { Não fique só, ande em comunidade, não se distancie da realidade } \\
\text { comunitária, essa realidade te ajuda no processo de socialização. } \\
\text { Não deixe de olhar para o pobre, não deixe de investir e se } \\
\text { relacionar com o pobre. Não deixe de dar uma boa risada de você } \\
\text { mesmo, não pense de você além do que você é, não pense de si } \\
\text { mesmo, mais do que deve pensar. } \\
\text { A fé crista é comunitária, falar do pobre é pensar que o poder não } \\
\text { é neutro ele corrompe, ilude e mente. Essa coisa do poder que } \\
\text { engana, essa coisa que você considerar o outro e o pobre é } \\
\text { relativizar a si mesmo, como sobreviver diante das tentações. Eu } \\
\text { fui falar no Comibam (2007) no México eu cheguei em uma } \\
\text { cadeira de rodas, falei uma vez por dia e estava fragilizado, a } \\
\text { questão do assedio, você não tem resistência. Uma questão do } \\
\text { poder midiático é você ter resistência para não se deixar seduzir. }\end{array}$ \\
\hline SE2 & $\begin{array}{l}\text { Ética, não cair na armadilha da vaidade, e do poder, o custo da } \\
\text { mídia, leva a pessoa a vender a alma para poder pagar o custo da } \\
\text { vinculação midiática. Outra recomendação é você ter um grupo } \\
\text { de pessoas a quem prestar contas, uma garantia que não vai tomar } \\
\text { decisões erradas. }\end{array}$ \\
\hline SE3 & $\begin{array}{l}\text { Cautela sempre, uma das palavras, descrição, e colocar-se sempre } \\
\text { como telespectador, o que eu quero receber em casa, como } \\
\text { cristão ou o que você quer dar para os seus filhos, para a família, } \\
\text { o que a família precisa, seja a formação de multiface o que a } \\
\text { família precisa receber. O que precisamos oferecer para a família. }\end{array}$ \\
\hline SE4 & $\begin{array}{l}\text { Espirito de pobreza a mídia não deve nos fazer ricos, pastor e } \\
\text { padre que ficam ricos com a mídia dão mau testemunho. } \\
\text { Repensar a teologia da prosperidade, é uma aberração do } \\
\text { evangelho. Repensar o cuidado com os pobres. O Dizimo se torna } \\
\text { uma imposição, não pode ser deve ser obediência. } \\
\text { Repensar o papel dos padres e pastores midiáticos que aparecem } \\
\text { demais e outros colegas não tem chance, a teve religiosa está nas } \\
\text { mãos de famílias religiosas, Universal é de uma família, Renascer } \\
\text { é de uma família, Igreja da graça, Igreja católica, Rede Vida é de } \\
\text { uma família, Igreja mundial, uma família, está nas mãos de } \\
\text { famílias fazem } 30 \text { anos que está nas mãos deles, isso é um feudo } \\
\text { religioso, associação de igrejas e mais fácil, Record também } \\
\text { família. } \\
\text { A igreja existe para servir o povo, não para atender necessidades } \\
\text { de famílias, estão ficando ricos e as igrejas pobres, igual futebol, } \\
\text { poucos ricos e outros jogadores procurando emprego, pastores e } \\
\text { padres estão sendo respeitados por seu ministério por alguns } \\
\text { poucos estão dominando tudo. }\end{array}$ \\
\hline
\end{tabular}

